Arteriais

revista do programa de pós-graduação em artes | ica | ufpa

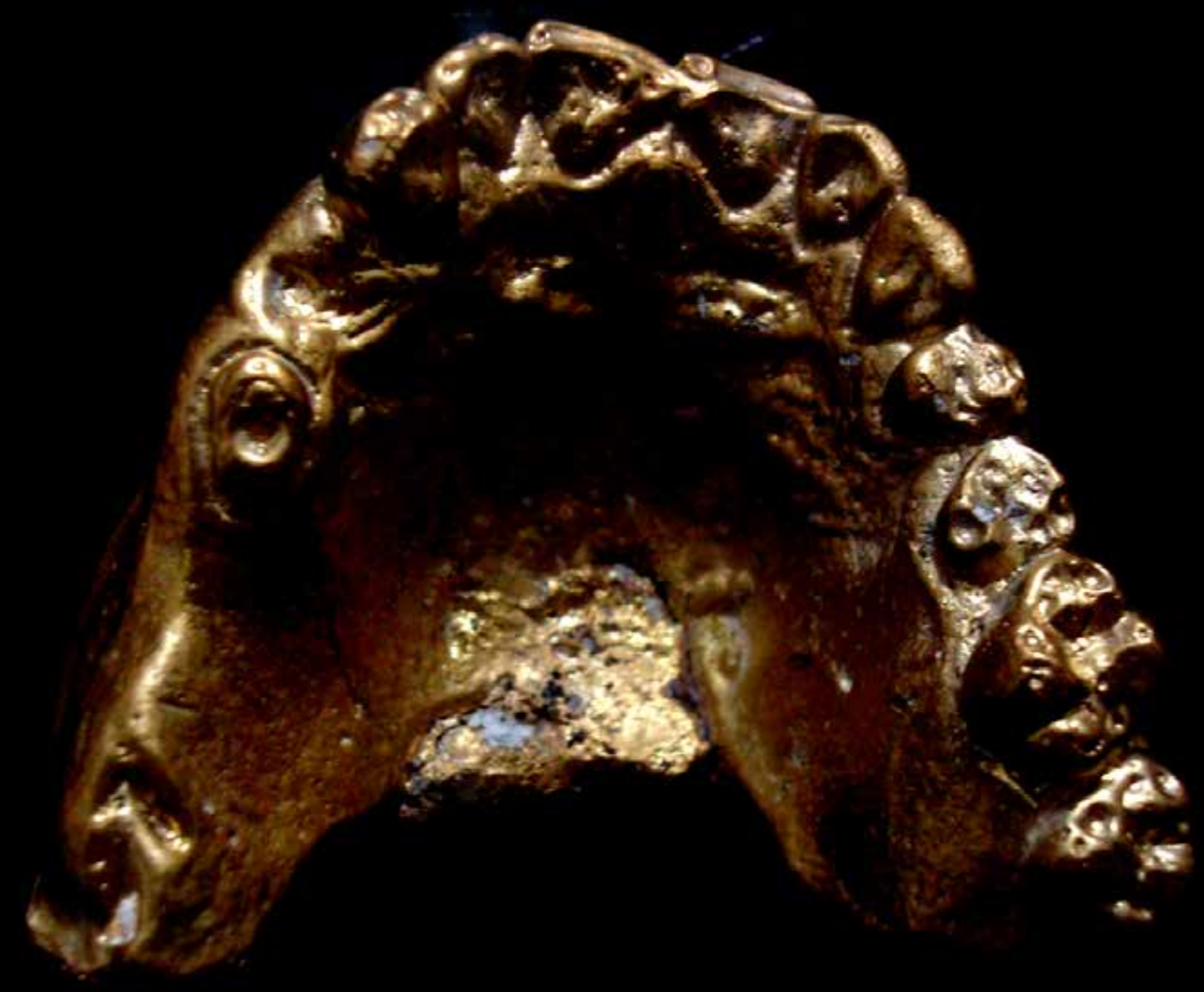


Realização
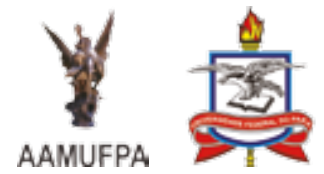

\section{MINISTÉRIO DA}

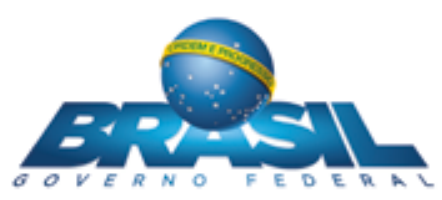

Esse projeto foi contemplado pelo Programa de Estímulo às Artes Visuais - Revistas

Todos os esforços foram feitos para contactar com os detentores dos direitos das imagens. Em caso de omissão, faremos todos os ajustes possíveis na primeira oportunidade. Esta é uma publicação sem fins lucrativos, e encontra-se livre de pagamentos de direito de autor no Brasil, protegida pela Lei № 9.610, Título III, Cap. IV, Art. 46, Inciso VIII. 


\section{Arteriais}

revista do programa de pós-graduação em artes | ica | ufpa 
MANESCHY, Orlando, MARTINS, Bene Afonso (org.)

Revista Arteriais, Ano 03, n. 04 - Belém, Pará, Programa de Pós-Graduação em Artes/Instituto de Ciências da Arte/ UFPA, junho de 2017 $182 \mathrm{p}$.

ISSN 2446-5356
1. Artes Visuais
2. Artes Cênicas
3. Música
4. História e Teoria da Arte

I. Universidade Federal do Pará 


\section{ARTERIAIS $\gg$}

Ano 03 | n. 04 | 2017

Revista do Programa de Pós-Graduação em Artes | ICA | UFPA

Pró-Reitoria de Pesquisa | Periódicos - Portal de Revistas Científicas da UfPA

\section{Reitor}

Prof. Dr. Emmanuel Zagury Tourinho

\section{Vice-Reitor}

Prof. Dr. Gilmar Pereira da Silva

Pró-Reitor de Pesquisa

Prof. Dr. Rômulo Simões Angélica

\section{Diretor de Pesquisa}

Profa. Dra. Germana Maria Araújo Sales

Diretora Geral do Instituto de Ciências da Arte

Adriana Azulay

Diretor Adjunto do Instituto de Ciências da Arte

Joel Cardoso

Coordenadora do Programa de Pós-Graduação em Artes

Bene Afonso Martins

Vice-Coordenador do Programa de Pós-Graduação em Artes

Ana Flávia Mendes

\section{Coordenadora do PROF-ARTES/ Mestrado Profissional}

Olinda Charone

\section{FICHA TÉCNICA}

\section{Editores científicos}

Orlando Maneschy | Bene Afonso Martins

\section{Editores Responsáveis}

Keyla Sobral | Breno Filo

Bolsista do programa

Keyla Sobral | Breno Filo

\section{Comitê editorial}

Bene Afonso Martins | Ana Flávia Mendes | Orlando Maneschy 


\section{Conselho Editorial}

\section{Visuais}

Afonso Medeiros, Universidade Federal do Pará, Belém-PA. André Parente, Universidade Federal do Rio de Janeiro, Rio de Janeiro-RJ. Cristina Freire, Universidade de São Paulo, São Paulo-SP. Elisa Souza Martinez, Universidade de Brasília, Brasília-DF. Gilberto Prado, Universidade de São Paulo, São Paulo-SP. Jens Michael Baungarten, Universidade Federal de São Paulo, São Paulo-SP. João Paulo Queiroz, Faculdade de Belas-Artes da Universidade de Lisboa, Lisboa - Portugal. Lúcia Pimentel, Universidade Federal de Minas Gerais, Belo Horizonte-MG. Mabe Bethônico, Universidade Federal de Minas Gerais, Belo Horizonte-MG. Maria Beatriz Medeiros, Universidade de Brasília, Brasília-DF. Maria Ivone dos Santos, Universidade Federal do Rio Grande do Sul, Porto Alegre-RS. Maria Luiza Távora, Universidade Federal do Rio de Janeiro, Rio de Janeiro-RJ. Marisa Mokarzel, Universidade da Amazônia, Belém-PA.

Norval Baitello Júnior, Pontifícia Universidade Católica de São Paulo, São Paulo-SP. Orlando Maneschy, Universidade Federal do Pará, Belém-PA. Rosana Horio Monteiro, Universidade Federal de Goiás, Goiânia-GO. Sérgio Basbaum, Pontifícia Universidade Católica de São Paulo, São Paulo-SP. Valzeli Sampaio, Universidade Federal do Pará, Belém-PA.

\section{Musicais}

Carlos Augusto Vasconcelos Pires, Universidade Federal do Pará, Belém-PA. Carlos Sandroni, Universidade Federal de Pernambuco, Recife-PE.

Catarina Domenici, Universidade Federal do Rio Grande do Sul, Porto Alegre-RS.

Celso Loureiro Chaves, Universidade Federal do Rio Grande do Sul, Porto Alegre-RS. Cristina Gerling, Universidade Federal do Rio Grande do Sul, Porto Alegre-RS.

Cristina Tourinho, Universidade Federal da Bahia, Salvador-BA.

Diana Santiago, Universidade Federal da Bahia, Salvador-BA.

Fernando lazzetta, Universidade de São Paulo, São Paulo-SP. Jusamara Souza, Universidade Federal do Rio Grande do Sul, Porto Alegre-RS. Líliam Barros Cohen, Universidade Federal do Pará, Belém-PA. Luis Ricardo Queiroz, Universidade Federal da Paraíba, João Pessoa-PB. Paulo Castagna, Universidade Estadual Paulista Júlio de Mesquita Filho, São Paulo-SP. Paulo Murilo Guerreiro do Amaral, Universidade do Estado do Pará, Belém-PA. Robin M. Wright, University of Florida, Florida-EUA. Samuel Araújo, Universidade Federal do Rio de Janeiro, Rio de Janeiro-RJ. Sérgio Figueiredo, Universidade do Estado de Santa Catarina, Florianópolis-SC. Sonia Chada, Universidade Federal do Pará, Belém-PA. Sonia Ray, Universidade Federal de Goiás, Goiânia-GO.

\section{Cênicas}

Ana Flávia Mendes Sapucahy, Universidade Federal do Pará, Belém-PA. Maria de Lourdes Rabetti, Universidade Federal do Estado do Rio de Janeiro, Rio de Janeiro-RJ. Cesário Augusto Pimentel de Alencar, Universidade Federal do Pará, Belém-PA. Fernando Marques, Universidade de Brasília, Brasília-DF. Maria Manuel Batista, Universidade do Minho e de Aveiro, Minho, PT. Miguel Santa Brígida, Universidade Federal do Pará, Belém-PA. Wladilene de Sousa Lima (Wlad Lima), Universidade Federal do Pará, Belém-PA. 


\section{Revisão:}

Joel Cardoso Silva

\section{Revisão Técnica:}

Keyla Sobral | Orlando Maneschy

\section{Programação Visual:}

Keyla Sobral | Breno Filo | Orlando Maneschy

\section{Diagramação:}

Breno Filo

\section{Capa:}

Armando Queiroz, Ouro de Tolo, 2010.

\section{Agradecimentos:}

Armando Queiroz

Ítala Clay de Oliveira Freitas

Rafael de Figueiredo Lopes

Maria do Céu Diel Oliveira

Amanda Gatinho Teixeira

Iomana Rocha

Ana Flávia Mendes

Walace Rodrigues

Cristiano Alves Barros

Edson Hansen Sant'Ana

Natalie Mireya Mansur Ramirez

Raquel Stolf

Fundação Nacional de Artes (Funarte)

Ana Paula Siqueira

Ana Paula Santos

Associação dos Amigos do Museu da UFPa

Museu da UFPa

Ministério da Cultura 


\section{SUMÁRIO}

Editorial

Portfólio

Armando Queiroz

Fluxos Semióticos: Aproximações Ecossistêmicas entre Comunicação e Arte

Ítala Clay de Oliveira Freitas, Rafael de Figueiredo Lopes

A Angústia da Influência nas Artes Visuais, como na literatura, com Harold Bloom

Maria do Céu Diel Oliveira

Um olhar sobre a poética dos parangolés de Hélio Oiticica

Amanda Gatinho Teixeira

A gambiarra e o alegórico no cinema contemporâneo brasileiro Iomana Rocha

Samba e balé clássico na construção coreográfica de uma porta-bandeira: aproximações com a dança imanente

Ana Flávia Mendes

Cinema e identidade cultural brasileira: possíveis reflexões para uso de filmes em sala de aula

Walace Rodrigues, Cristiano Alves Barros

A concepção intervalar na poética pós-ruptura: uma análise da Sonata $n 0^{\circ} 3$ de Almeida Prado

Edson Hansen Sant'Ana

O que é Performance? Entre contexto histórico e designativos do termo

Natalie Mireya Mansur Ramirez

Sob/sobre notas-desenhos de escuta

Raquel Stolf 


\section{REVISTA ARTERIAIS $\gg>$ EDITORIAL}

Diálogos cruzados entre música, cinema, dança e artes visuais, refletem, de maneira crítica e poética, suas potências, articulando acerca de um território fértil, território de possibilidades. A Arteriais no 04 traz artigos heterogêneos, múltiplos, abordando a arte, seus processos de criação, seus alcances estéticos e políticos.

Na seção PORTFÓLIO Armando Queiroz apresenta sua maneira de pensar a arte, sua experiência poética de grande teor político, sua fala feito grito! Brado de um artista resistente, vindo das águas barrocas da Amazônia, que aborda a violência de maneira ímpar, consciente, apontando e subvertendo, com seu olhar arguto, a lógica do dominador.

Na seção dos ARTIGOS, temos diálogos sobre os territórios da arte, em fluxos Semióticos: Aproximações Ecossistêmicas entre Comunicação e Arte, Ítala Clay de Oliveira Freitas e Rafael de Figueiredo Lopes trazem reflexões sobre Comunicação e Arte, pelas dimensões do sensível e da cognição, sublinhando o caráter expressivo no entrelaçamento entre esses dois campos do conhecimento. A literatura e as artes visuais estão presentes nesta edição, no artigo A Angústia da Influência nas Artes Visuais, como na literatura, com Harold Bloom onde Maria do Céu Diel Oliveira analisa os escritos que buscam entender a possibilidade de migrar as categorias poéticas elencadas por Harold Bloom na Angustia da Influência - clinamen, tessera, kenosis, demonização, askesis e apófrades - para as artes visuais como forma de entendimento, compreensão e superação da influência poética/artística. Em Um olhar sobre a poética dos parangolés de Hélio Oiticica, Amanda Gatinho Teixeira aborda a poética de Hélio Oiticica mediante os Parangolés, sua obra emblemática, em que o espectador tornandose participador, pode vestir a cor, dançar, movimentar-se e ter a experiência sensorial e pictórica em seu próprio corpo. Em A gambiarra e o alegórico no cinema contemporâneo brasileiro, Iomana Rocha fala sobre e bom aproveitamento do acaso, da gambiarra, proporcionando reflexões acerca da imagem cinematográfica, do emprego da "estética da gambiarra" e o que dela resulta e contribui para a direção de arte no cinema brasileiro contemporâneo.

No âmbito das discussões que envolvem a dança, o artigo Samba e balé clássico na construção coreográfica de uma porta-bandeira: aproximações com a dança imanente, onde Ana Flávia Mendes Sapucahy relata sua experiência artística-poética vivida como porta-bandeira do Auto do Círio, cortejo cênico realizado anualmente em Belém do Pará em homenagem à Nossa Senhora de Nazaré, padroeira dos paraenses. Já no artigo Cinema e identidade cultural brasileira: possíveis reflexões para uso de filmes em sala de aula, Walace Rodrigues e Cristiano Alves Barros abordam o contexto educacional que envolve a arte e articula sobre como o cinema pode funcionar em sala de aula do Ensino Médio enquanto gerador de informações sociais, históricas e culturais.

No que tange as questões que envolvem a música, temos A concepção intervalar na poética pósruptura: uma análise da sonata n.o 3 de Almeida Prado, onde Edson Hansen Sant'Ana analisa a póetica do compositor Almeida Prado, indo da pós-ruptura ao tonalismo; relata sobre o espaço multi-sistêmico do compositor, chamado transtonalismo, bem como trata da comprovação analítica voltada para o problema intervalar em uma das obras utilizadas para uma pesquisa mais abrangente, que se ampliou e se verificou ocorrente em mais de 100 obras do referido autor. No artigo o que é Performance? Entre contexto histórico e designativos do termo, Natalie Mireya Mansur Ramirez pretende explorar questões relacionadas 
aos designativos do termo performance, levando em consideração a abrangência de campos do conhecimento que esta envolve através de autores nacionais e internacionais, bem como alguns exemplos históricos. E fechando esta edição temos Sob/sobre notas-desenhos de escuta de Raquel Stolf, onde a artista nos apresenta texto potente sobre suas investigações em torno de experiências de silêncio, bem como acerca de propostas de escrita, leitura e escuta que pendem segundo ângulos de suspensão (usos de uma palavra pênsil) e de processos que envolvem uma escuta porosa.

São múltiplos os diálogos que irrompem com o desejo de contribuir para um debate sobre a arte, discursos que nos ajudam a compreender, cada vez mais, o meio cultural contemporâneo.

Os editores

Belém do Pará, inverno 2016 | 2017. 
Todos os esforços foram feitos para contactar com os detentores dos direitos das imagens. Em caso de omissão, faremos todos os ajustes possíveis na primeira oportunidade. Esta é uma publicação sem fins lucrativos, e encontra-se livre de pagamentos de direito de autor no Brasil, protegida pela Lei № 9.610, Título III, Cap. IV, Art. 46, Inciso VIII.

(cTodos os direitos e responsabilidades sobre as imagens e textos pertencem aos seus autores

12 Arteriais | revista do ppgartes | ica | ufpa|n. 04 Jul 2017 


\section{PORTFOLIO $\gg$ P ARMANDO QUEIROZ}

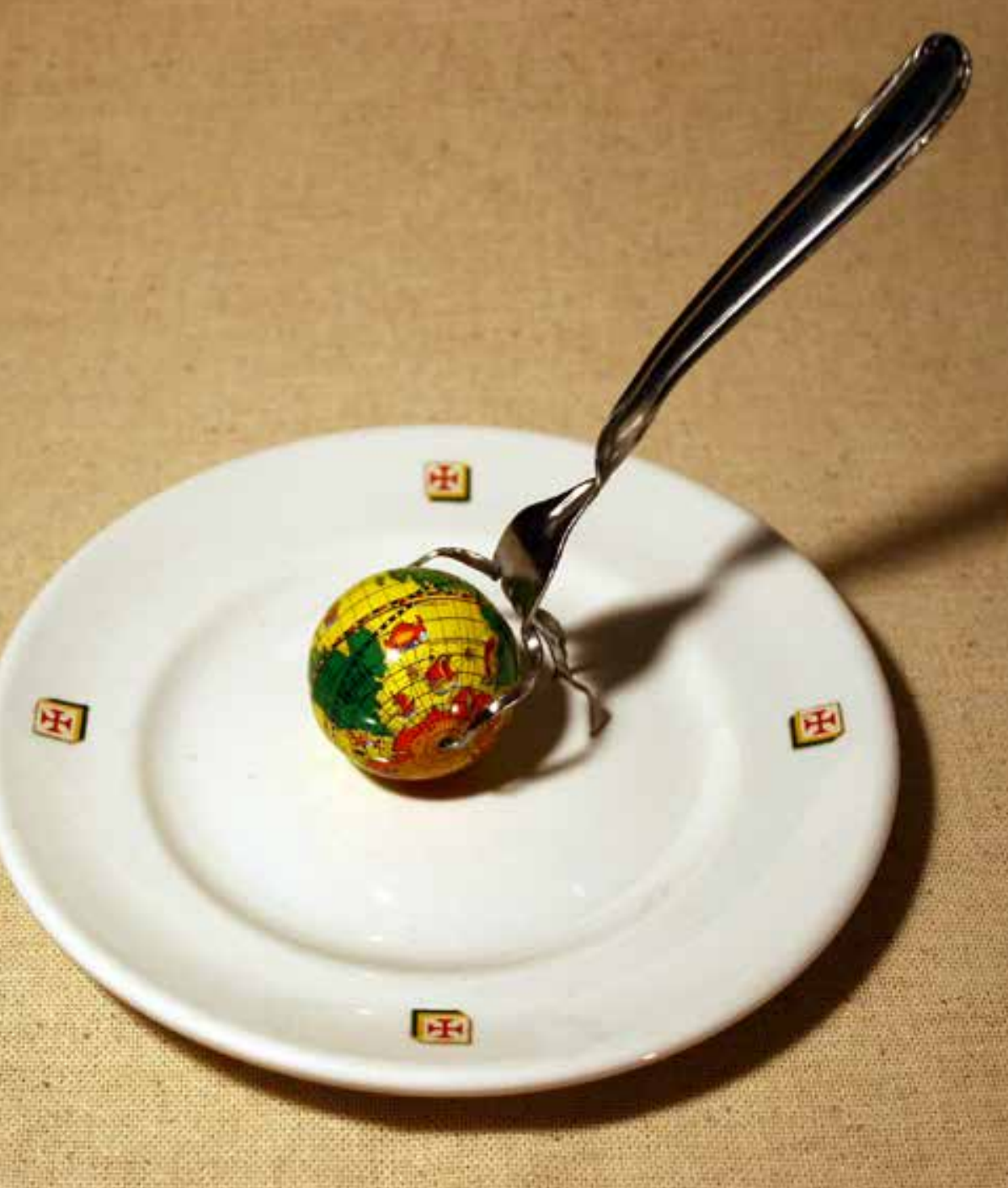




\section{UMA PRIMEIRA RESPOSTA PROMETIDA AO REBOTALHO DE ARMANDO QUEIROZ}

Como eles chegaram sem grandes certezas? Como eles cruzaram um Além-Mar com força e coragem? Lembro da carta de Caminha... Ali veríeis galantes, pintados de preto e vermelho, e quartejados, assim pelos corpos como pelas pernas, que, certo, assim pareciam bem. Também andavam entre eles quatro ou cinco mulheres, novas, que assim nuas, não pareciam mal. Entre elas andava uma, com uma coxa, do joelho até o quadril e a nádega, toda tingida daquela tintura preta; e todo o resto da sua cor natural. Outra trazia ambos os joelhos com as curvas assim tintas, e também os colos dos pés; e suas vergonhas tão nuas, e com tanta inocência assim descobertas, que não havia nisso desvergonha nenhuma. E o português nunca mais foi o mesmo sob os encantos das curvas dessas mulheres e homens fortes e naturalmente sem as vergonhas cobertas.

Valentes e possantes eram os da terra. Amáveis, mas também aguerridos quando necessário. E sim, fortes, muito fortes. Haveriam uns, com suas alegrias e liberdades, e suas próprias lógicas, e os seus entendimentos do mundo, com seus seres criadores, entes e conexões com o mundo natural, espiritual, físico. Tudo era harmonia com a natureza ali, até eles chegarem... Encontrados e amados ferozmente, com toda a hipocrisia da saudade, Oswald tirando a prova dos nove. De lá prá cá miséria, fome, ilusão, pobreza e doença. Ouço o apito... é o trem.... oiço o apito.... é o trem.... e tantas riquezas sendo tiradas e arrancadas desses buracos, boca aberta, peito arrebatado de folhas e terra devastada. Já não é... não é não... não querem deixar eles existirem. Contra as minorias, os pequeno-burgueses estão a bradar. Índio, Negro, Pobre... é apenas um índice impessoal presente em chacinas continuadas e amplificadas numa situação que não podemos mais temer. Pois a vida é bonita, é bonita, sim senhor e todos temos que existir e viver nossas loucuras e alegrias e desejos, trans, lesb, homo, indefinidos, e para as pessoas que estão no fundo do Brasil, nos rincões mais afastados, da Amazônia ao Sertão, do Arroio ao Chuí: Respeito. Paulo Herkenhoff já afirmou ser Armando Queiroz o artista a abordar a violência de maneira ímpar, ética e consciente. É preciso violentar a violência... O Herkenhoff que devorou a bienal com seu projeto antropofágico... percebeu... 落

É disso que a obra do artista aborda. Olhar agudo, dedo na ferida, o desmonte, a lupa para os signos sutis; a lente para questões emergenciais e abusos históricos. Da colônia, dos El Dourados fictícios, da Serra que ficou pelada e banguela, com miséria de sonhos devastados. Degredados Filhos de Eva... Não é discurso de moral ou religioso. Sou mais Guaraci, que aprendemos a conhecer, mesmo que num álbum $p$ colecionar com refrigerante, mas que, antes do mercado dos gazeificados, era figura natural, nossa mãe.

O artista fuçou. Revelou tantas violências... os jovens índios suicidas, os mineiros engolidos pelo sonho de riqueza... Midas.... a dissolução do ego com o Desapego do projeto Mirante... Queiroz... as ficções estrangeiras...os estrangeirismos internos. Já fomos tão... fome... e o senhor da estética vive ainda com saudades de Belle Époque... Que bom que o artista, diferente dos políticos, não tem o que temer, ... inteligente como é, vai devagar..., com sua voz compassada subvertendo..., questionando..., criando ambientes para trocas e diálogos. É ali, nesse espaço com o outro, pé na lama, chão de terra batida, vida explícita, que sutilmente, constrói seu discurso antiviolência. Esse era para ser uma primeira resposta ao texto Rebotalho. Eu sei... não penses que eu esqueci... como esquecer? Nem há motivo a temer.

Orlando Maneschy 


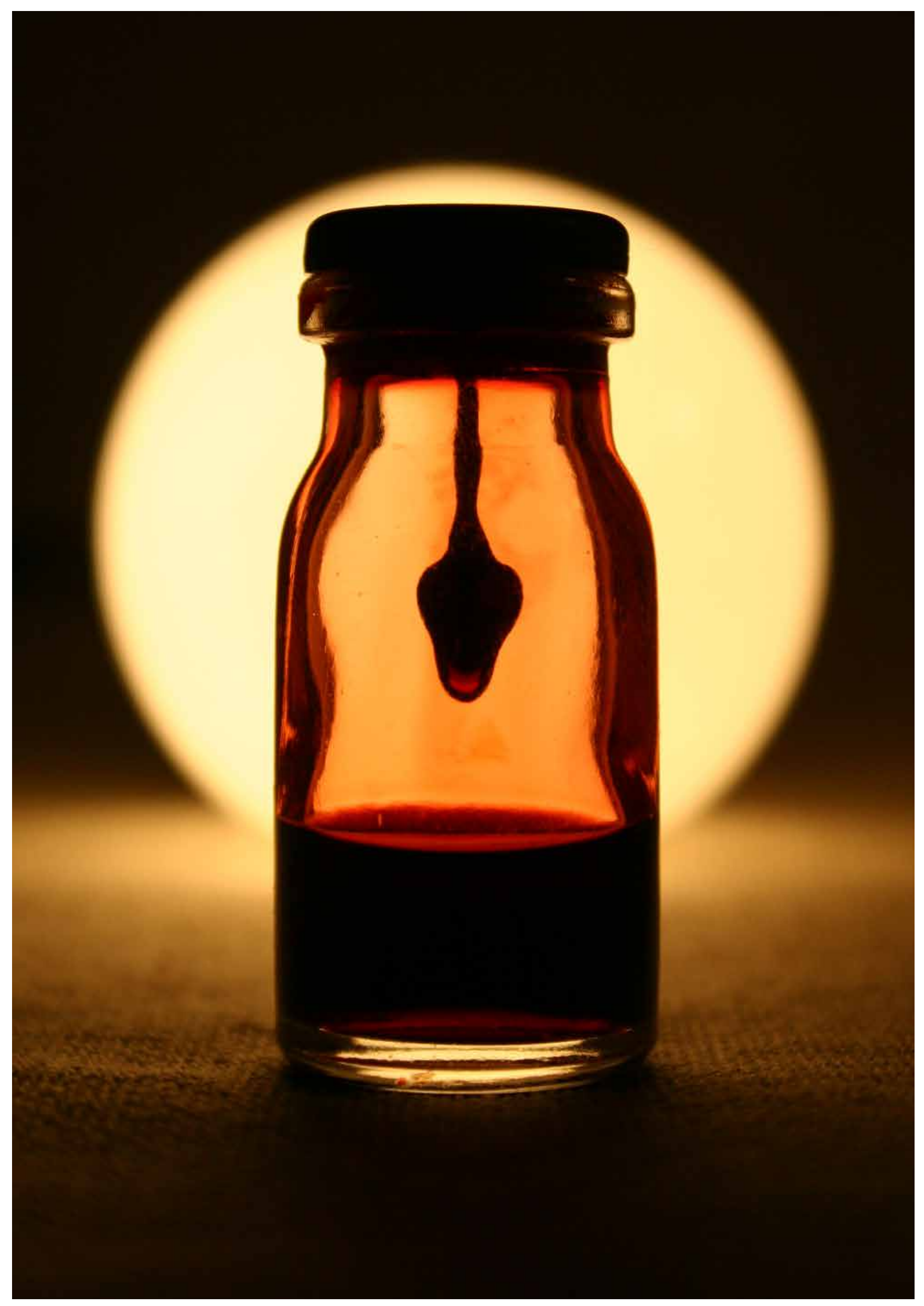

Prática espiritual da crucificação do Senhor, 1998-2005

Série Sermões 


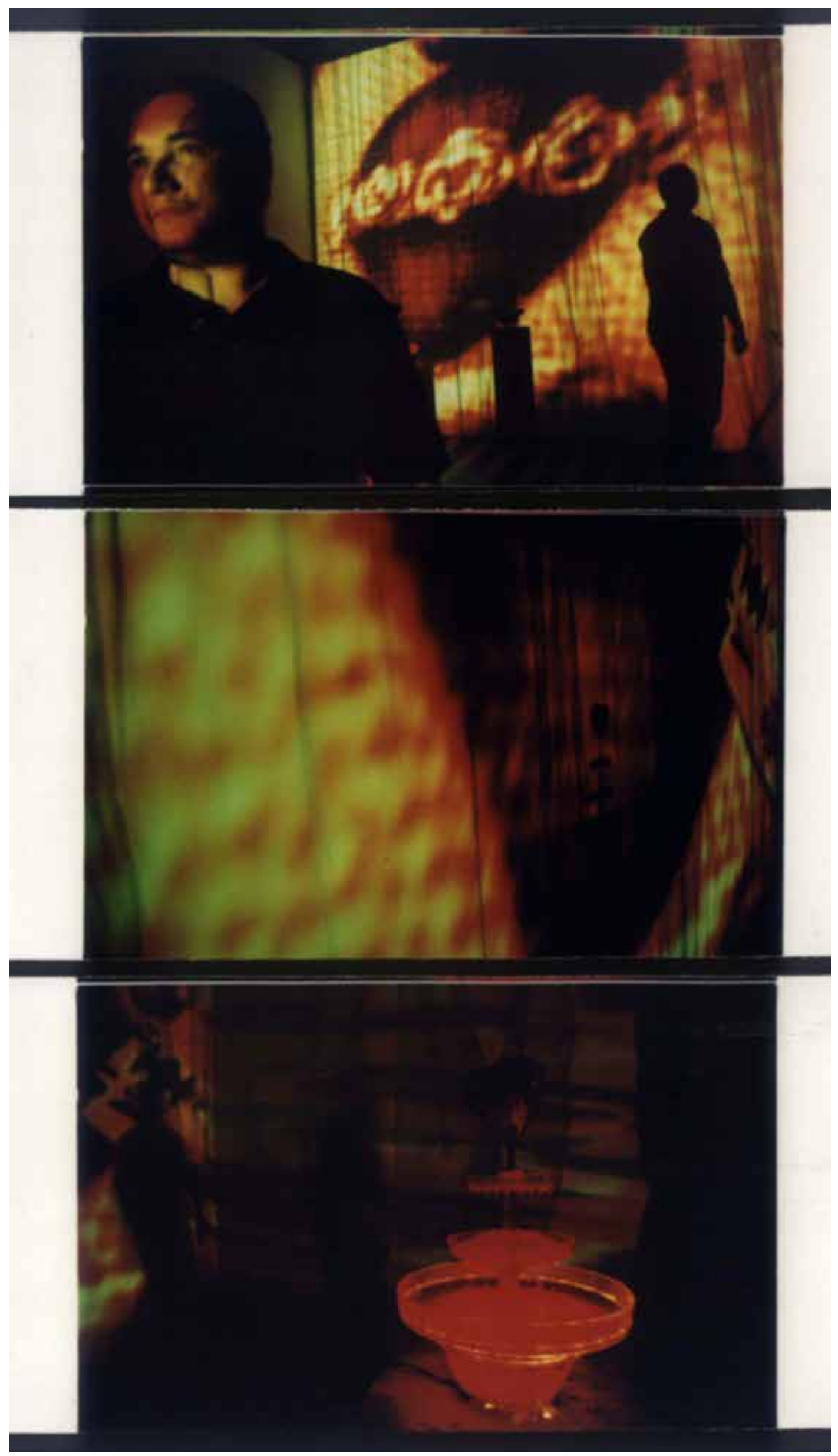

Banquete das Orações, 2001

Foto: Flavya Mutran

16 Arteriais | revista do ppgartes | ica | ufpa | n. 04 Jul 2017 


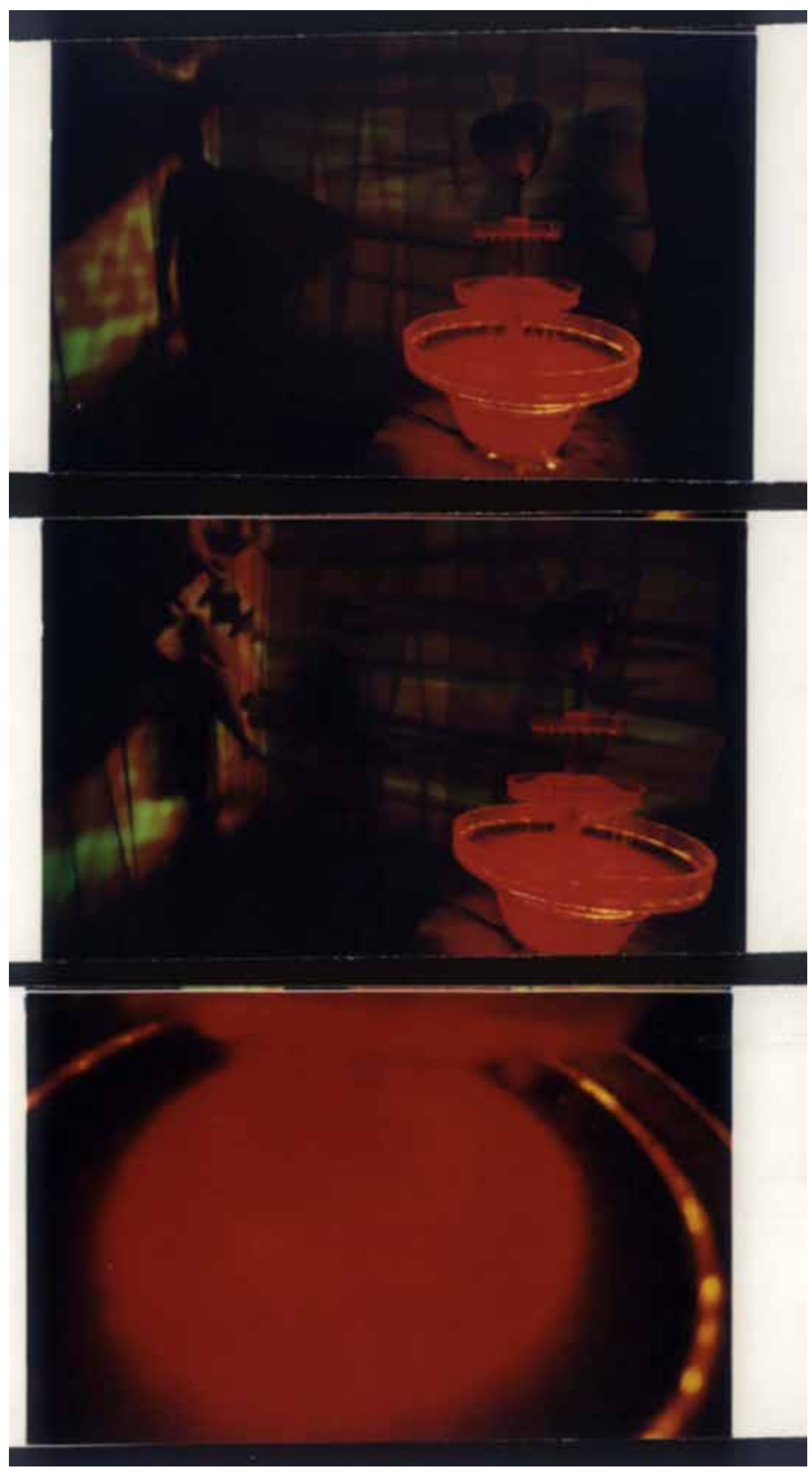

Banquete das Orações, 2001

Foto: Flavya Mutran 


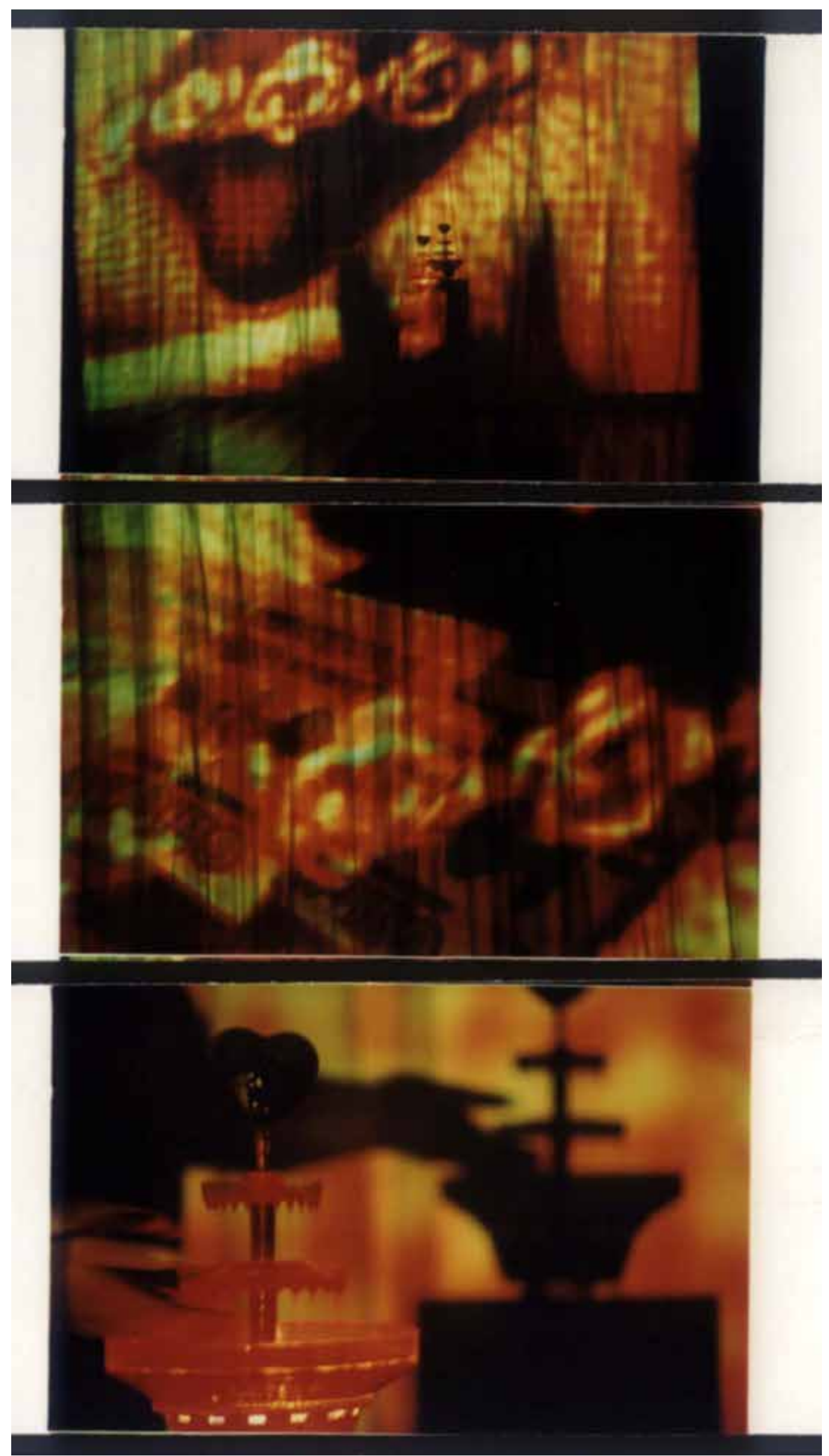

Banquete das Orações, 2001

Foto: Flavya Mutran 


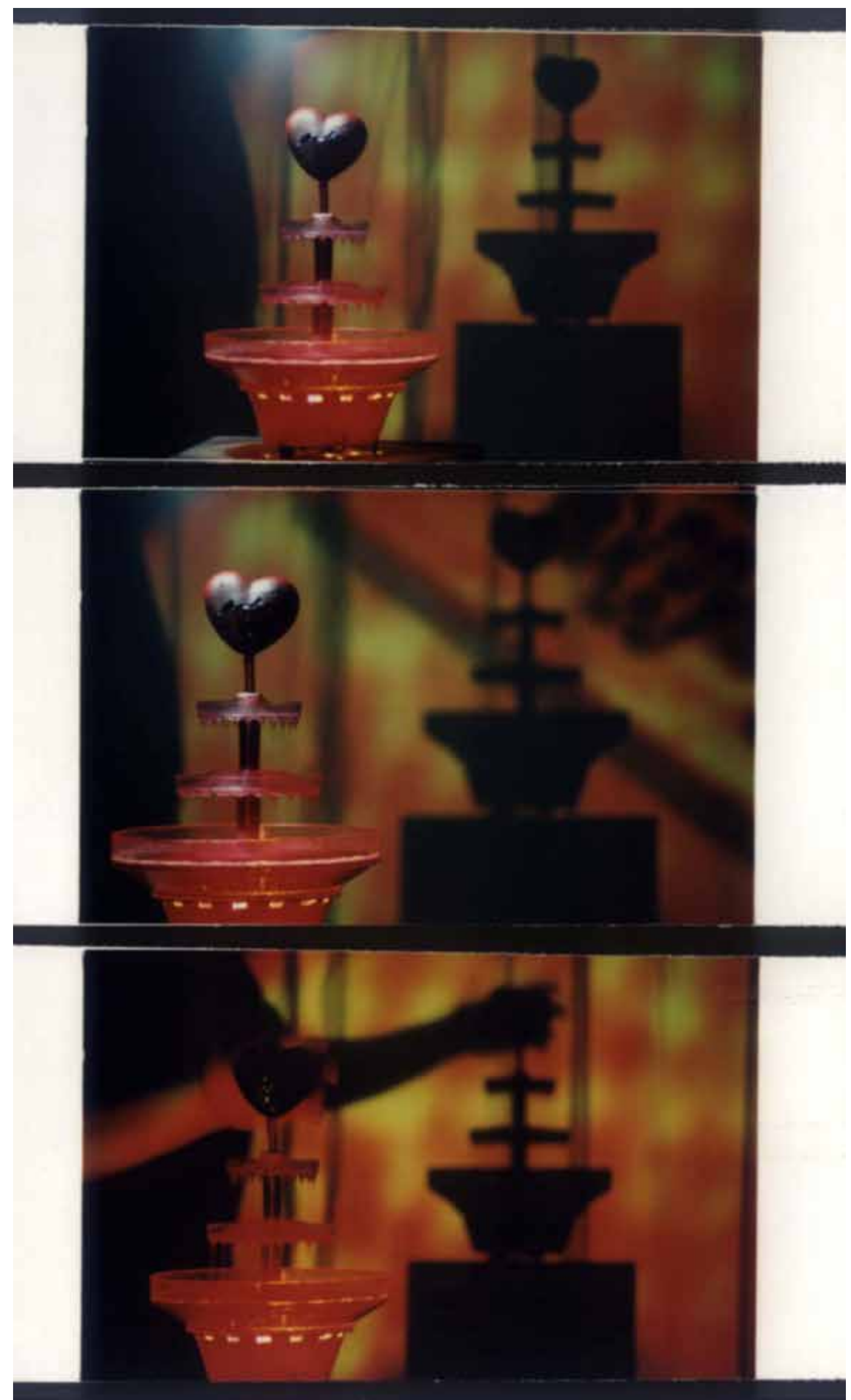

Banquete das Orações, 2001

Foto: Flavya Mutran 


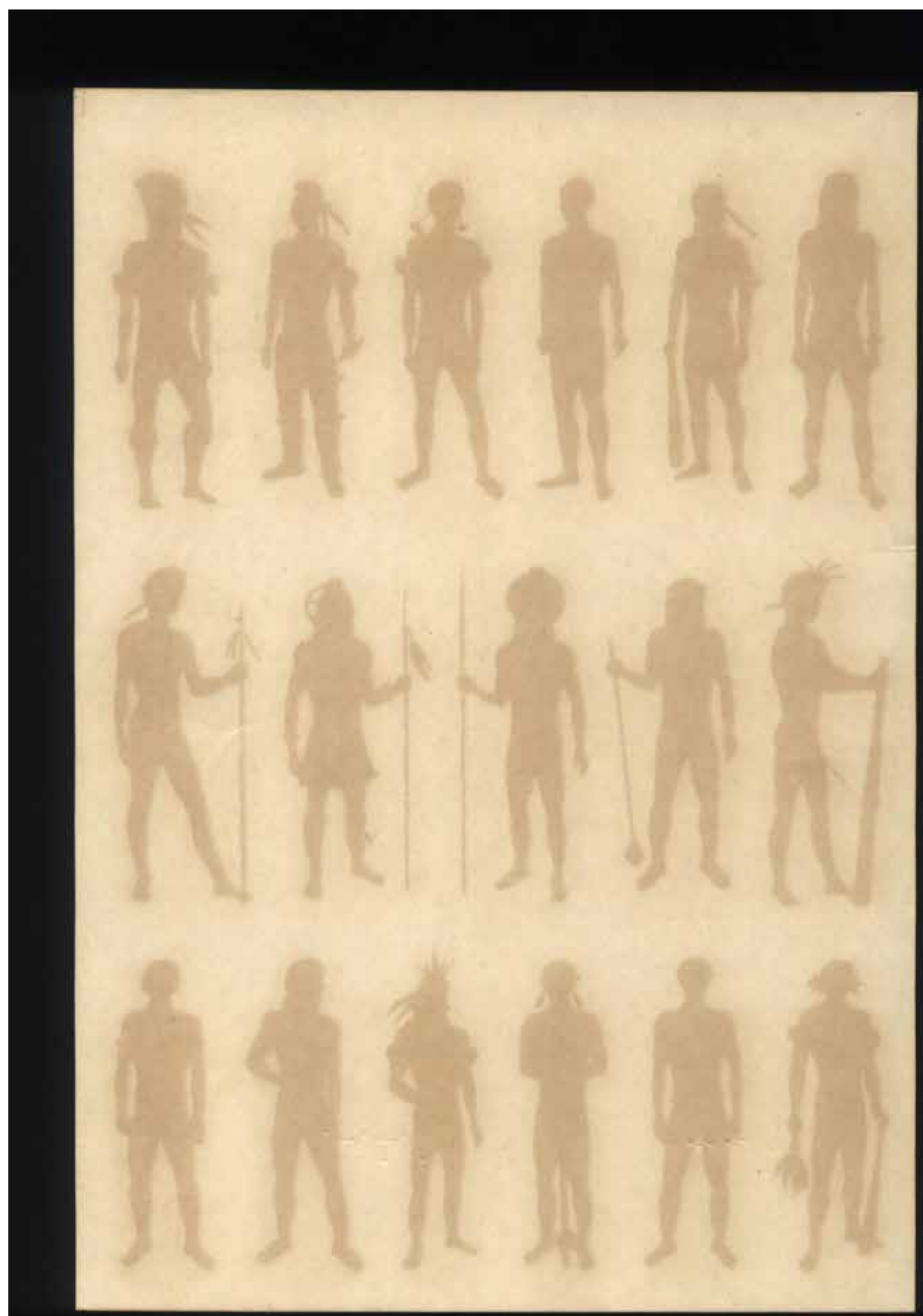

Conquista das Almas, 2006

Série Reduções

20 Arteriais | revista do ppgartes | ica | ufpa | n. 04 Jul 2017 


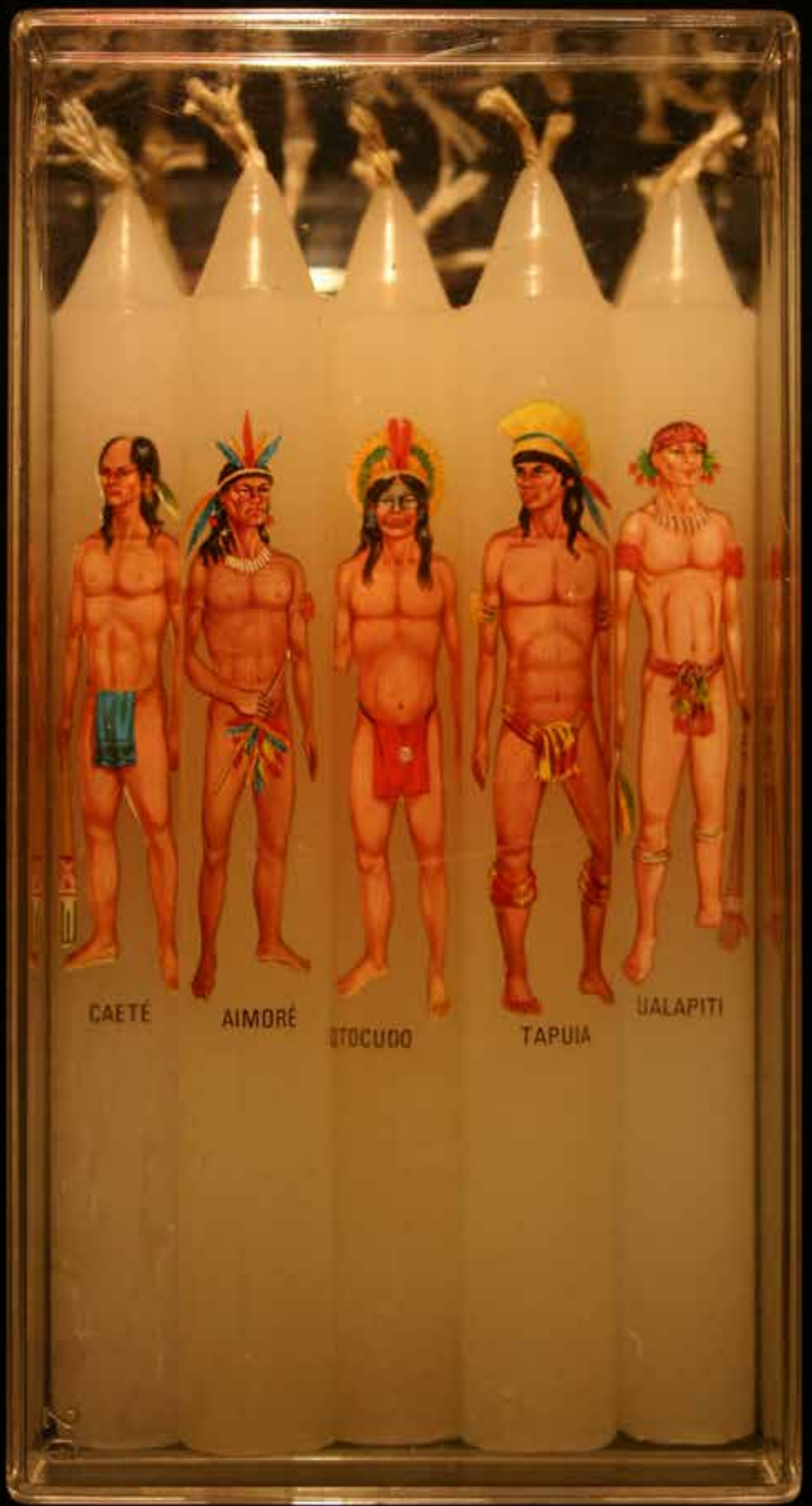

Reduções, 2006

Série Reduções 


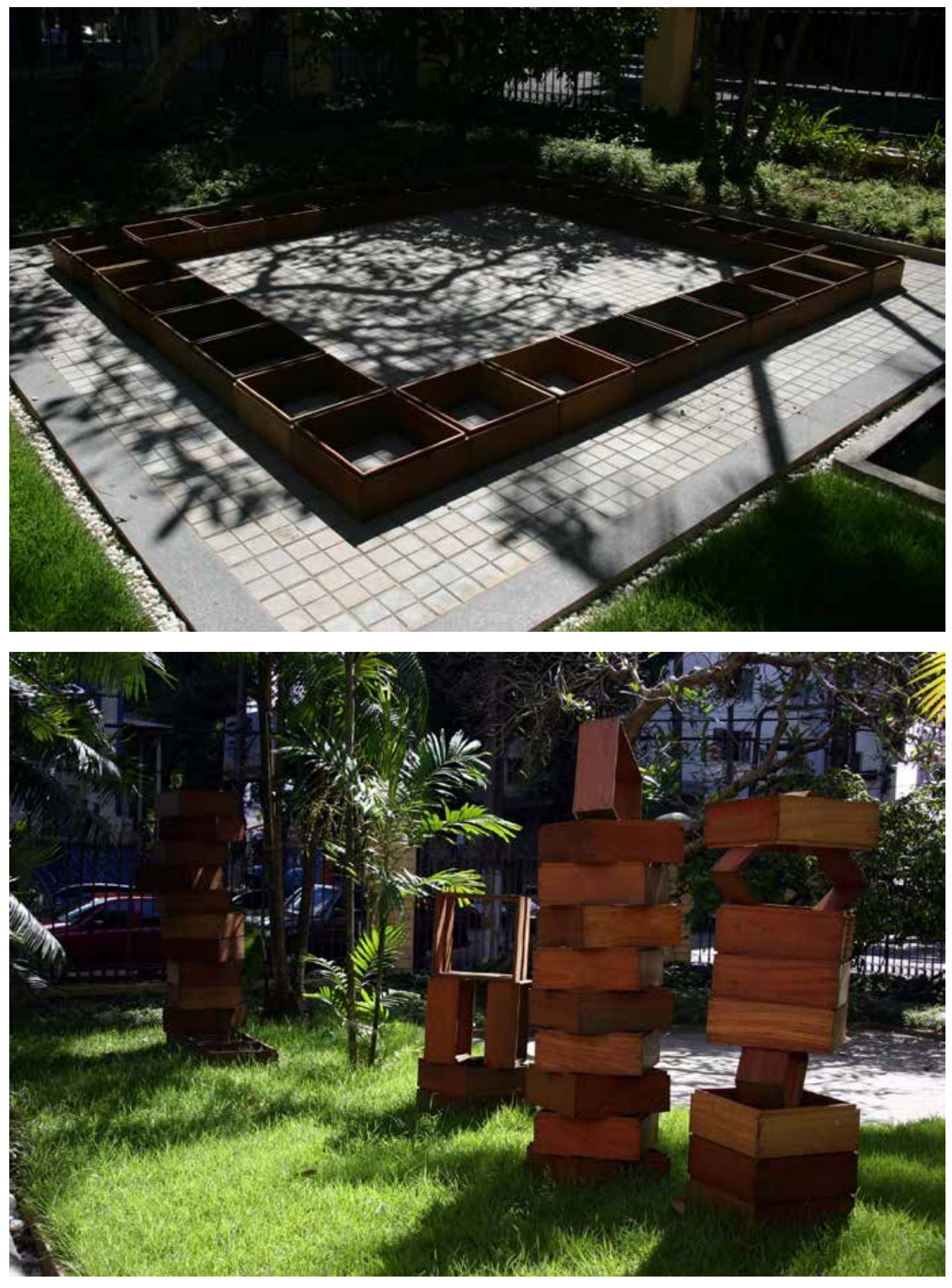

Projeto Mirante, 2006 

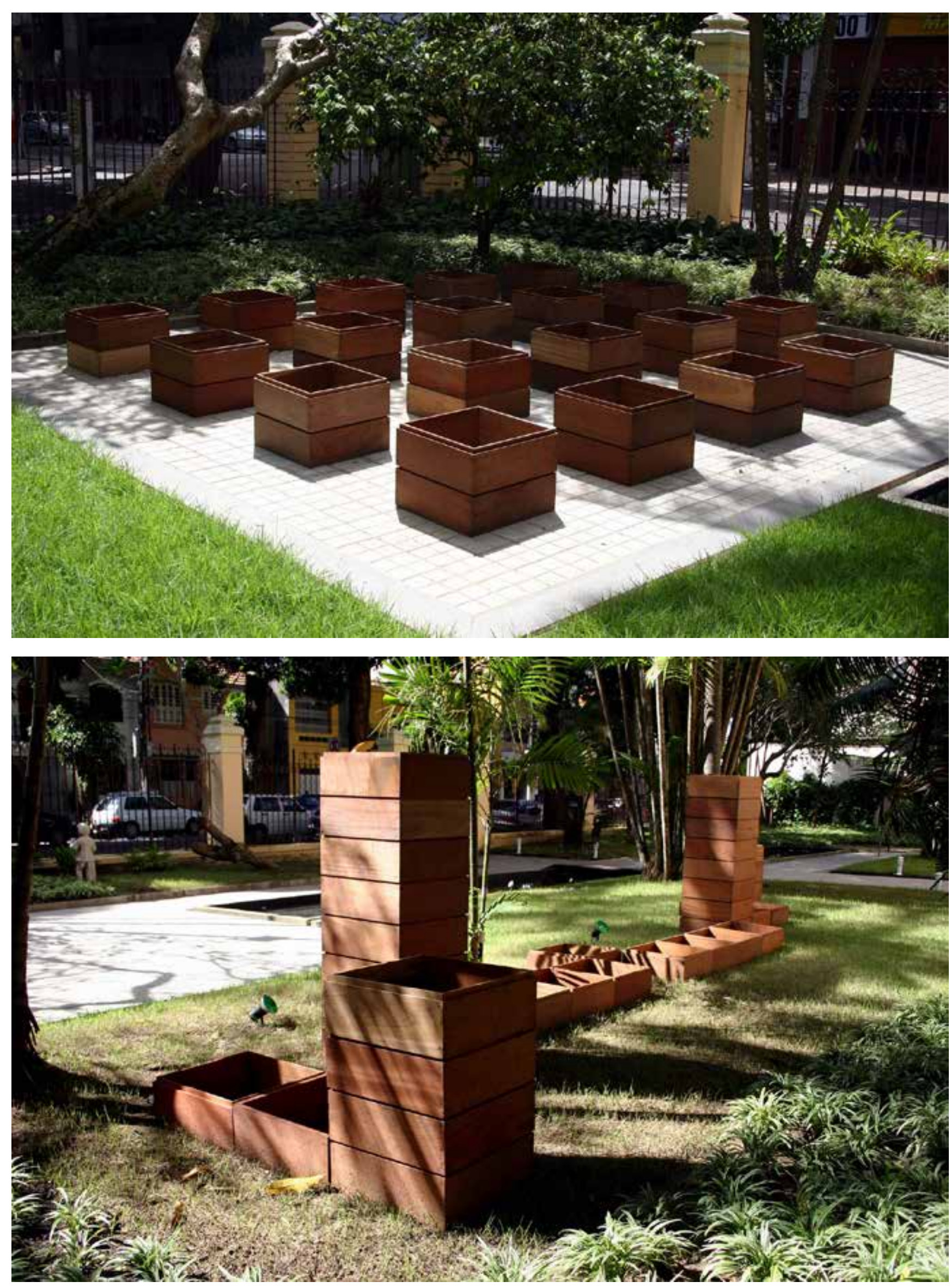

Projeto Mirante, 2006 


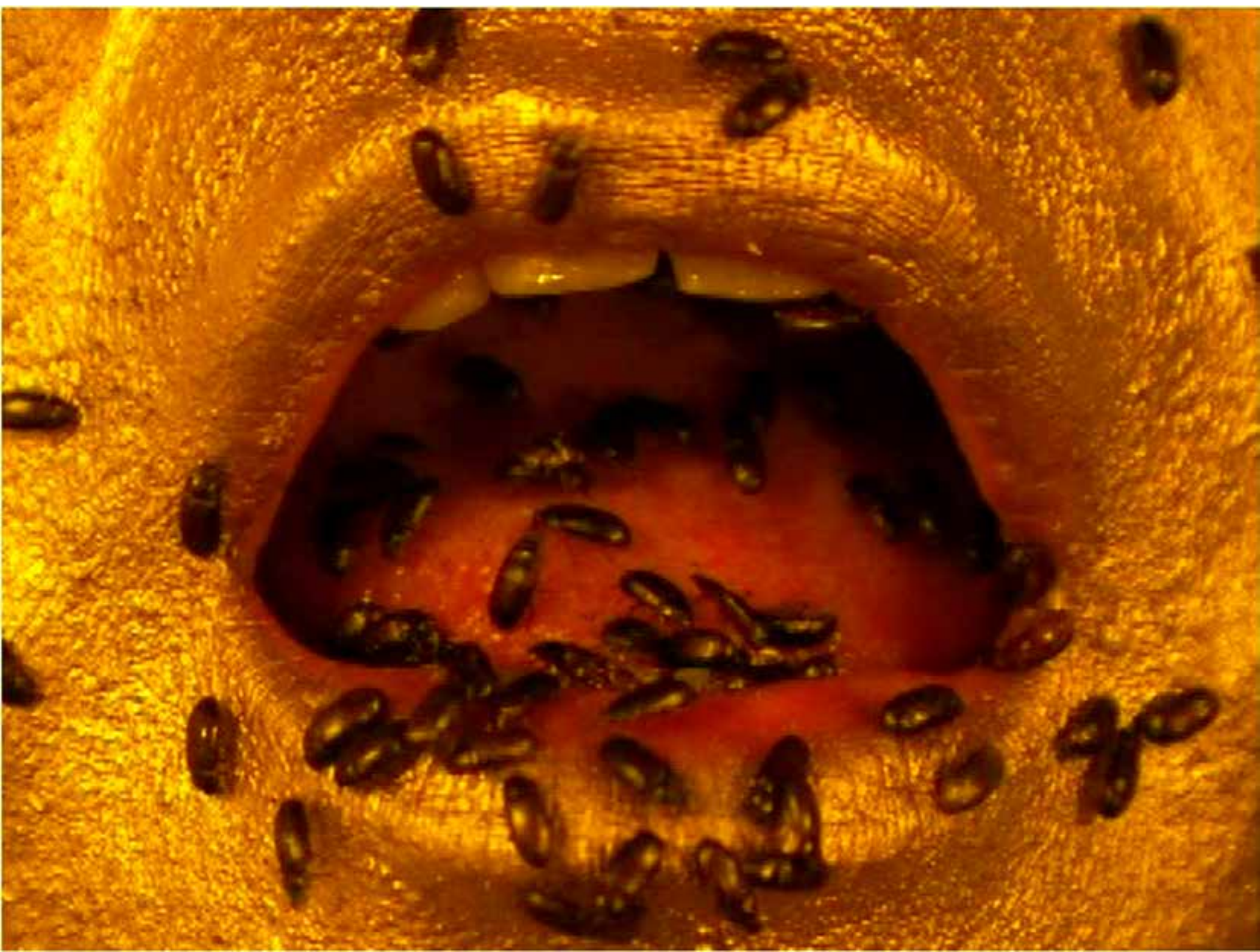

Midas, 2009

24 Arteriais | revista do ppgartes | ica | ufpa | n. 04 Jul 2017 

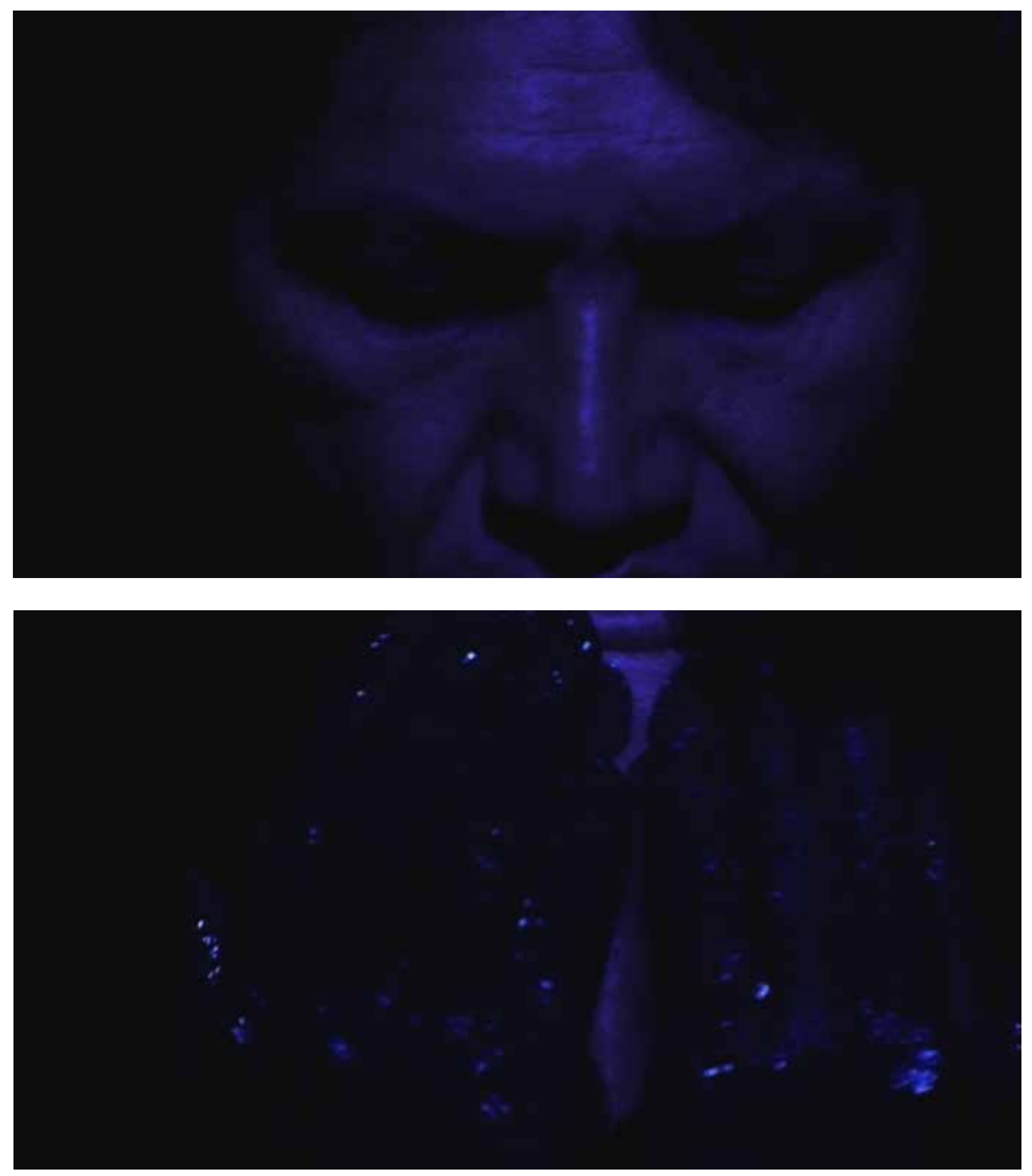

Ymá Nhandehetama, 2009 


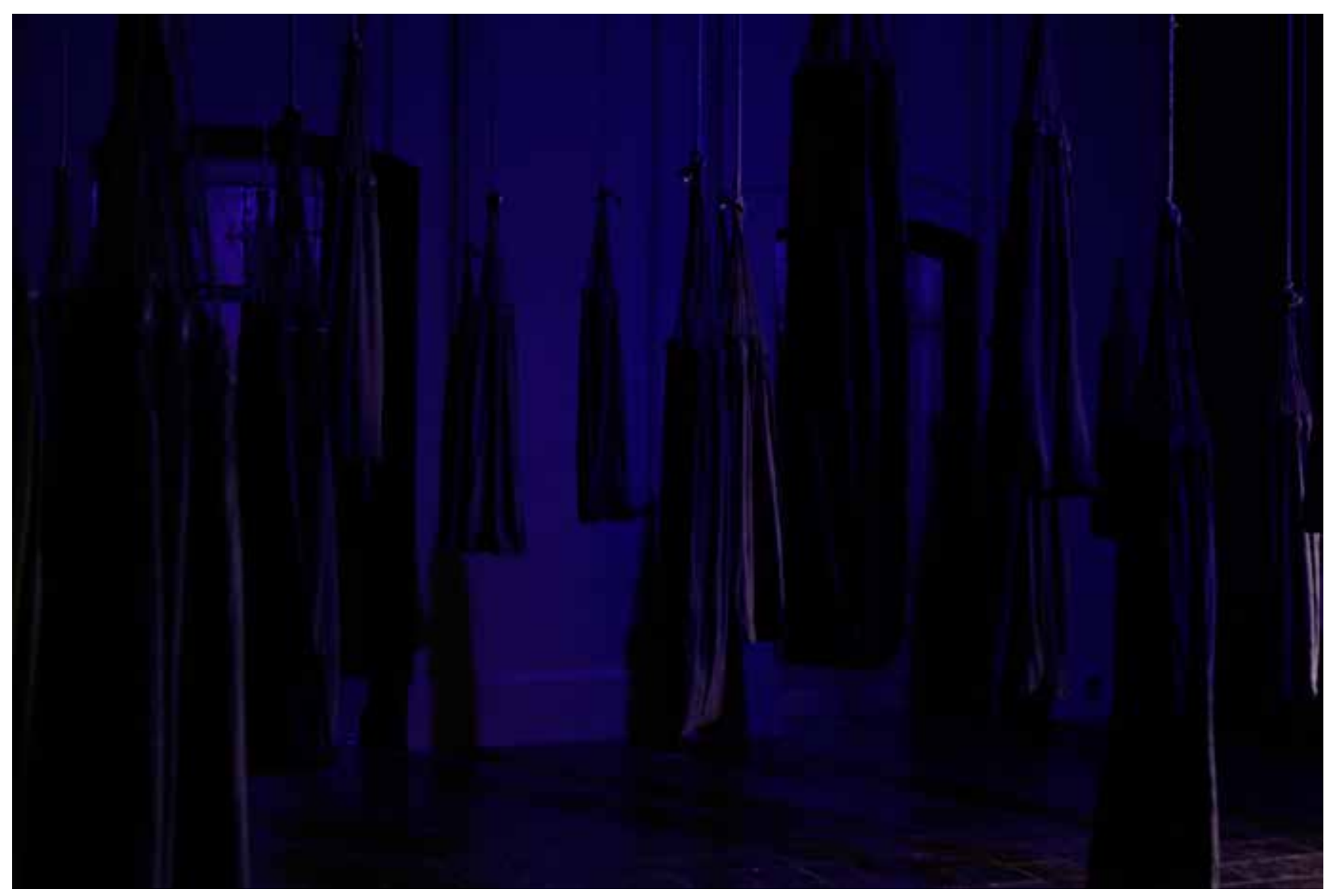

Cântico Guarani, 2010

Foto: Everton Ballardini

26 Arteriais | revista do ppgartes | ica | ufpa | n. 04 Jul 2017 


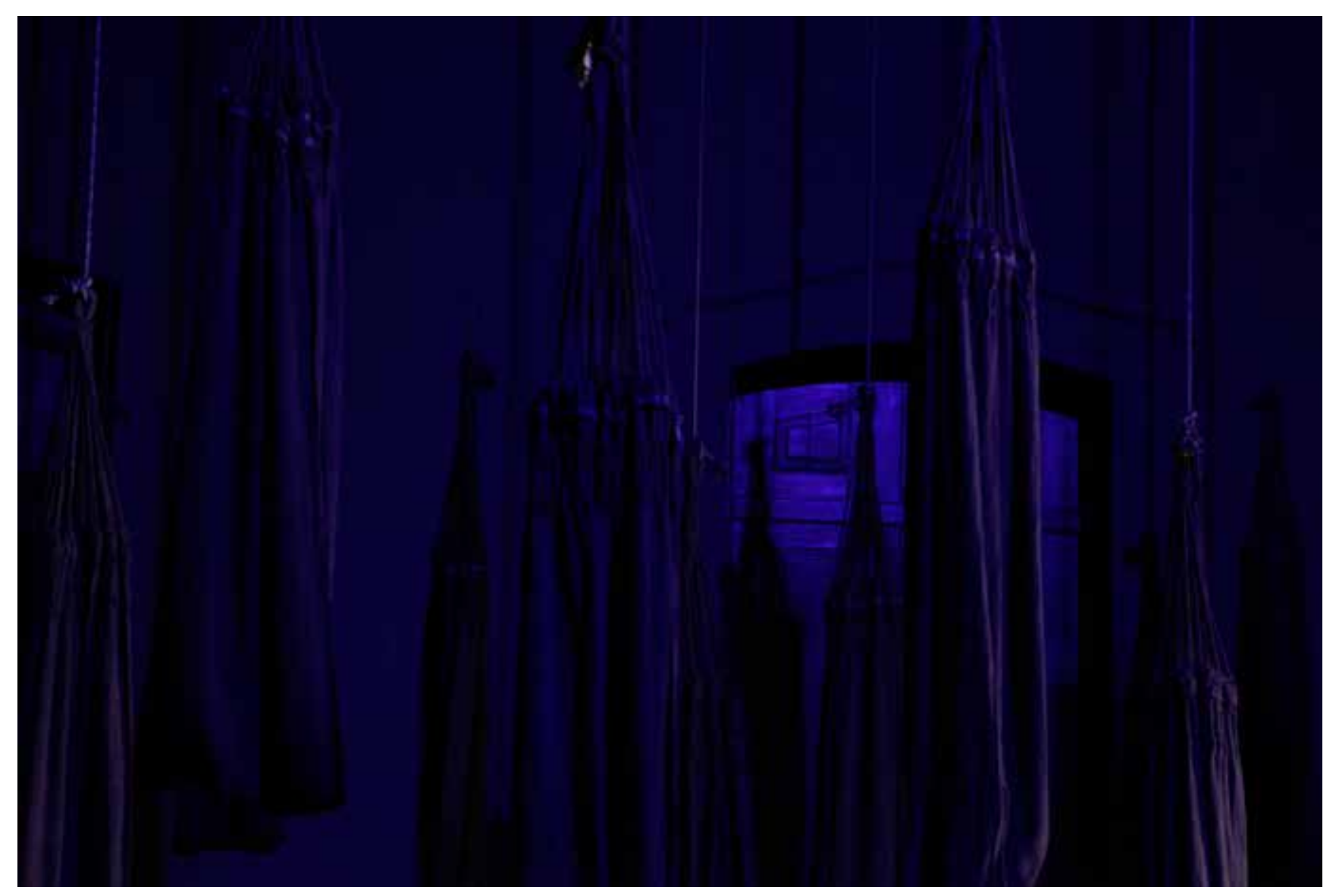

Cântico Guarani, 2010 Foto: Everton Ballardini 


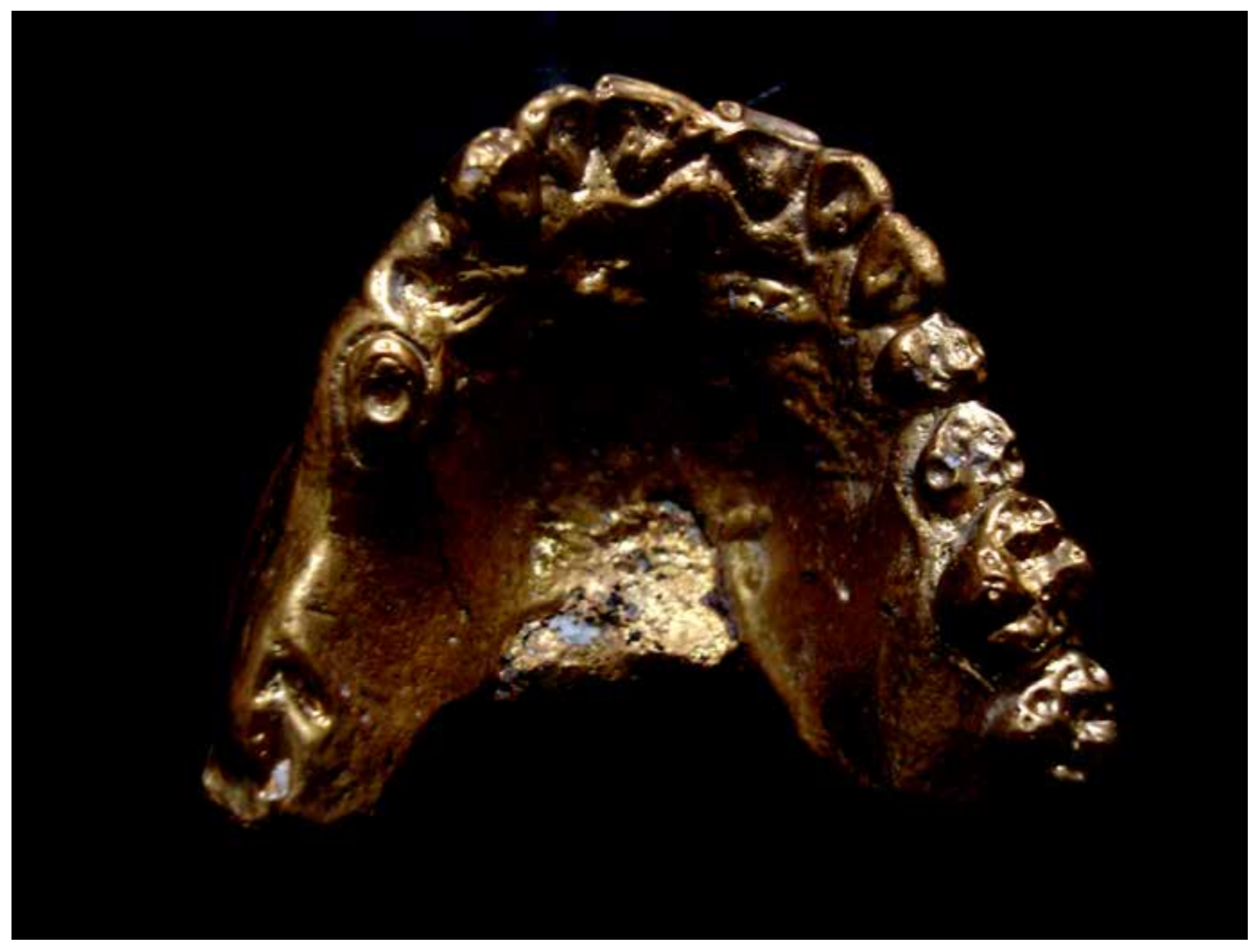

Ouro de tolo, 2010 


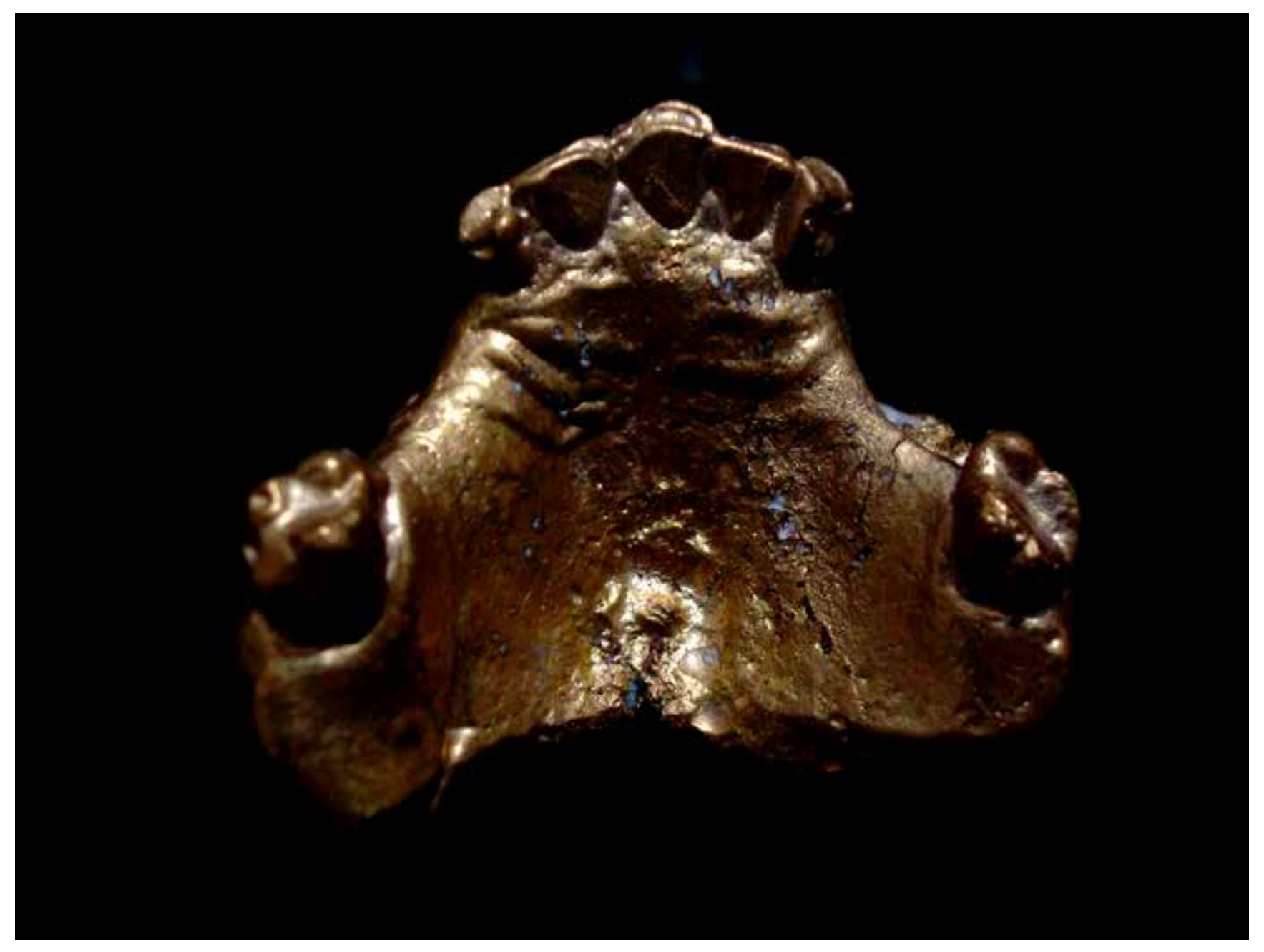




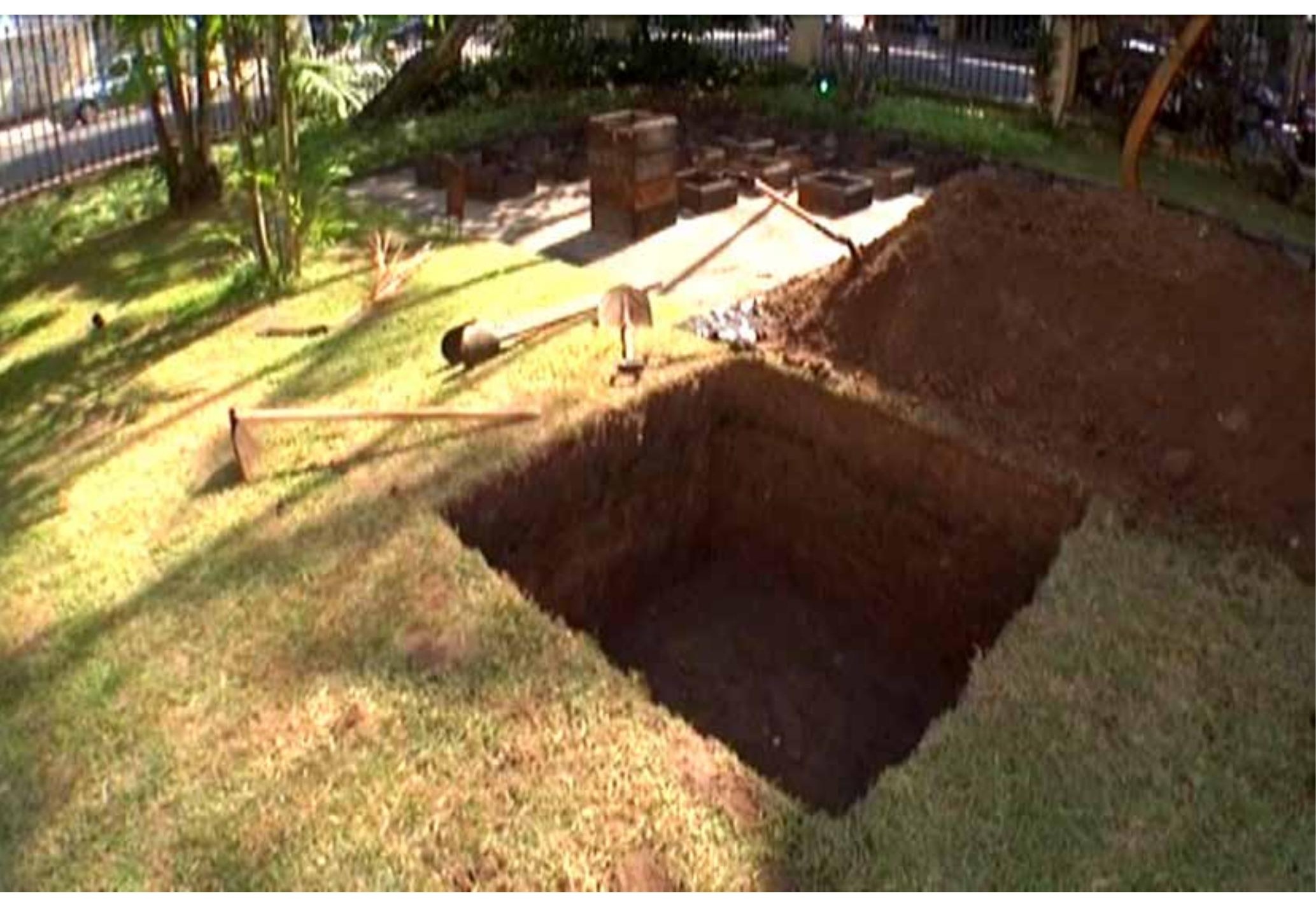




\section{Orlando Franco Maneschy (Texto).}

Pesquisador, artista, curador independente e crítico. Doutor em Comunicação e Semiótica pela PUC-SP. Desenvolveu estágio pós-doutoral na Faculdade de Belas Artes da Universidade de Lisboa. É professor na Universidade Federal do Pará, atuando na graduação e pós-graduação. Coordenador do grupo de pesquisas Bordas Diluídas (UFPA/CNPq). É articulador do Mirante - Território Móvel, uma plataforma de ação ativa que viabiliza proposições de arte. Curador da Coleção Amazoniana de Arte da UFPA. Como artista tem participado de exposições e projetos no Brasil e no exterior, como: Outra Natureza, Faculdade de Belas Artes da Universidade de Lisboa, 2015; Horizonte Generoso - Uma experiência no Pará, Galeria Luciana Caravello, Rio de Janeiro, 2015; Transborda, Galeria Casa Triângulo, São Paulo, 2015; Triangulações,Pinacoteca UFAL - Maceió, CCBEU - Belém e MAM - Bahia, de set. a nov. 2014; Pororoca: A Amazônia no MAR, Museu de Arte do Rlo de Janeiro, 2014 etc. Recebeu, entre outros prêmios, a Bolsa Funarte de Estímulo à Produção Crítica em Artes (Programa de Bolsas 2008); o Prêmio de Artes Plásticas Marcantonio Vilaça / Prêmio Procultura de Estímulo às Artes Visuais 2010 da Funarte e o Prêmio Conexões Artes Visuais - MINC | Funarte | Petrobras 2012, com os quais estruturou a Coleção Amazoniana de Arte da UFPA, realizando mostras, seminários, site e publicação no Projeto Amazônia, Lugar da Experiência. Realizou, as seguintes curadorias: Projeto Correspondência (plataforma de circulação via arte-postal), 2003-2008; Projeto Arte Pará 2008, 2009 e 2010; Amazônia, a arte, 2010; Contra-Pensamento Selvagem dentro de Caos e Efeito, com Paulo Herkenhoff, Clarissa Diniz e Cayo Honorato, 2011; Projeto Amazônia, Lugar da Experiência, 2012, dentre outras.

\section{Armando Queiroz (Portfólio).}

Mestrando da Escola de Belas Artes da UFMG. Sua produção artística abrange desde objetos diminutos até obras em grande escala e intervenções urbanas. Detêm-se conceitualmente às questões sociais, políticas e patrimoniais. Cria a partir de observações do cotidiano das ruas, apropria-se de objetos populares de várias procedências, tem como referência a cidade e o Outro. Foi contemplado com a bolsa de pesquisa em arte do Prêmio CNI SESI Marcantonio Vilaça para as Artes Plásticas 2009-2010. Em 2010, recebeu Sala Especial no 29) Arte Pará como artista homenageado do salão. Em 2011, participa da 16( Bienal de Cerveira, Fundação Bienal de Cerveira (Portugal) e da III Bienal do Fim do Mundo, Ushuaia (Argentina). Em 2012, é artista convidado do 64) Salão Paranaense. Em 2013, participa da XX Bienal Internacional de Curitiba. Em 2014, participa da 31( Bienal de São Paulo. Em 2015, participa da exposição Cinéma Permanent do Centre Pompidou-Metz (França). Já em 2016, participa da mostra Amazonian Video Art da Universit of Glasgow (Escócia). Vive e trabalha entre Belém e Belo Horizonte. 


\title{
FLUXOS SEMIÓTICOS: APROXIMAÇÕES ECOSSISTÊMICAS \\ ENTRE COMUNICAÇÃO E ARTE
}

\author{
Ítala Clay de Oliveira Freitas \\ Rafael de Figueiredo Lopes \\ UFAM-AM
}

\section{Resumo}

O artigo apresenta pressupostos acerca da perspectiva inter e transdisciplinar de Ecossistemas Comunicacionais, indicando aportes e trilhas teóricas que embasam esse "conceito aberto", que preconiza um diálogo contextual com os novos arranjos da ciência e pensadores voltados a uma compreensão sistêmica e complexa dos fenômenos, reconhecendo o dinamismo e a interdependência dos acontecimentos físicos, biológicos e socioculturais. Nesse sentido propõe uma reflexão entre Comunicação e Arte, pelas dimensões do sensível e da cognição, sublinhando o caráter expressivo no entrelaçamento entre esses dois campos do conhecimento. A abordagem teóricometodológica é feita a partir da semiótica, em diálogo-trama com aspectos da história, antropologia, processos de criação, e estudos sobre o corpo e o ambiente. Desse modo, apresenta uma possibilidade de leitura por meio de inter-relações e interdependências, sugerindo uma compreensão relacional estabelecida na significação de sistemas de representação, por meio de processos criativo-comunicacionais.

\section{Palavras-chave:}

Comunicação; Ecossistemas Comunicacionais; Arte; Semiótica.

\section{INTRODUÇÃO}

Este artigo propõe uma aproximação ecossistêmica entre Comunicação e Arte. Partimos de aportes teóricos acerca da proposta conceitual de Ecossistemas Comunicacionais, perspectiva emergente no campo da Comunicação, imbuída em ideias do pensamento complexo e sistêmico, que tem ganhado inúmeros desdobramentos investigativos e lastro institucional no Programa de Pós-Graduação em Ciências da Comunicação da Universidade Federal do Amazonas.

\section{Abstract}

This paper presents conjectures about the transdisciplinary perspective of Communicative Ecosystems, indicating theoretical contributions that support this concept outlined by new arrangements of science and focused on the systemic and complex understanding of phenomena, recognizing the dynamism and interdependence of physical, biological and sociocultural events. Accordingly proposes a reflection of Communication and Art, the dimensions of cognition, emphasizing the links between these two fields of knowledge. The theoretical and methodological approach of semiotics, dialoguing with aspects of history, anthropology, creative processes, and studies on the body and the environment. Thus, it shows a possible reading through interactions and interdependencies, suggesting a relational established understanding the meaning representation systems by means of creative and communication processes.

Keywords:

Communication; Communicative Ecosystems; Art; Semiotics.

Desse modo, salientamos o caráter inter e transdisciplinar dessa abordagem, que investiga os fenômenos comunicacionais pelas interações entre o ser humano, o ambiente, a cultura e a tecnologia. Uma perspectiva que contesta pensamentos e métodos cartesianos-newtonianos e teorias clássicas da comunicação, pois não descarta as subjetividades e incertezas das circunstâncias envolvidas nos processos comunicacionais. Assim, a compreensão dos fenômenos ocorre a partir da trama relacional entre seus elementos, quebrando paradigmas de abordagens tradicionais 
que reduzem a complexidade comunicativa a uma dimensão funcionalista e simplificadora.

Essa ideia encontra consonância em Capra (2002) para quem a ciência precisa ser sustentável, redefinida na relação do ser humano com a natureza, analisando os fenômenos pela integração das dimensões biológica, cognitiva e social da vida, e adotando uma visão sistêmica para enfrentar os problemas que vão da ordem do mundo prático aos questionamentos filosóficos. Ou seja, não apenas focada em fenômenos materiais, mas contemplando o que decorre do campo dos significados.

Dessa forma, segundo Capra (2002), a comunicação e a criatividade são inerentes aos sistemas vivos e às dinâmicas dos fenômenos biológicos e físicos, o que também se aplica ao universo cultural. De acordo com Capra (2002), imerso em ideias do neurobiólogo Humberto Maturana, a comunicação não é simplesmente transmissão de informação, mas a coordenação de comportamentos por meio de acoplamentos estruturais mútuos entre organismos vivos.

Conforme Capra (2002) a arte também vem influenciando a sociedade em questionar os padrões do modelo científico mecanicista, principalmente, a partir do Movimento Romântico, no fim do século XVIII. Com a difusão de novas ideias, desde a música de Franz Schubert, da pintura de Francisco Goya e, principalmente, da literatura de Goethe, que já se referia à natureza como a forma orgânica de um todo harmonioso em seu aparente caos, e da filosofia de Immanuel Kant que compreendia a vida como um sistema integrado por muitas partes interdependentes, capazes de se reproduzir e se auto organizar.

Diante disso, propomos uma discussão acerca da relação entre comunicação e arte, numa perspectiva ecossistêmica dialogando com a semiótica, com base em Lucia Santaella, destacando conceituações acerca de linguagens, representações e estéticas comunicacionais, pois compreendemos que além de uma manifestação da sensibilidade da nossa espécie, a arte é uma forma de comunicação e produção de sentidos simbólicos.

O artigo é fundamentado em estudo teóricobibliográfico, a fim de revisar criticamente aspectos formulados acerca da proposta temática "Comunicação \& Arte". Entretanto, exploramos diferentes trilhas, experimentamos combinações e sugerimos conexões interpretativas, apontando uma possibilidade de leitura relacional. Tal concepção implicou num arranjo teórico-metodológico em movimento dialógico, como uma espiral que tangencia autores de diferentes áreas, para a melhor aproximação com um objeto caracterizado por deslocamentos fluidos na plasticidade de suas metamorfoses espaço-temporais.

Assim sendo, instauramos uma discussão sobre a comunicação humana pelas dimensões da sensibilidade e da cognição, enfatizando relações entre corpo, mente, cultura, ambiente e seus desdobramentos em processos de criação na arte. Para isso, compomos um mosaico conceitual, embasado em noções de história, antropologia, processos criativos, ecologia profunda, filosofia e neurociência.

A trama relacional, entre diferentes campos do conhecimento, proporcionou estabelecer múltiplas conexões, sinalizando inúmeras possibilidades e arranjos que podem ser articulados numa interpretação ecossistêmica. Lembrando que a concepção de Ecossistemas Comunicacionais não tem intenção de se tornar uma nova teoria da comunicação, mas se estrutura na medida em que reestrutura seus objetos, em mutáveis relações sistêmicas e complexas, como discutiremos a seguir.

\section{Uma perspectiva ecossistêmica comunicacional}

Ecossistemas Comunicacionais é uma concepção que dialoga com múltiplas conceituações teóricas e campos do conhecimento, propondo articulações sistêmicas, à complexidade e à imersão sensorial, rompendo a linearidade pragmática das teorias clássicas da comunicação, nas quais o fenômeno comunicativo se estabelece basicamente num processo emissor-mensagem-meio-receptor e a "comunicação só ocorre quando o receptor compreende o código da mensagem enviada", como salienta Littlejohn (1988).

Já é uma proposição institucionalizada, haja vista que é a área de concentração do Programa de Pós-Graduação em Ciências da Comunicação da Universidade Federal do Amazonas (PPGCCOM/ UFAM) $^{1}$. Iniciado em 2008, foi o primeiro Programa de Pós-Graduação na área de Comunicação do 
Norte do Brasil a ser aprovado pela Coordenação de Aperfeiçoamento de Pessoal de Nível Superior (Capes)2. Atualmente, suas investigações são guiadas por duas linhas de pesquisa: Redes e processos comunicacionais; e Linguagens, representações e estéticas comunicacionais.

Assim sendo, o desenvolvimento da perspectiva ecossistêmica na UFAM, parte de investigações que consideramacomplexidadesistêmicaeinformacional dos fenômenos comunicativos, "propondo estudos sobre os processos de organização, transformação e produção das mensagens conformadas na cultura a partir das interações entre sistemas sócioculturais-tecnológicos" (MONTEIRO; ABBUD; PEREIRA, 2012, p. 09). É um campo de estudos que encontrou no contexto amazônico "um espaço emblemático para a exploração das interferências mútuas entre as diferentes esferas que regem a vida, a comunicação e a cultura" (IBID, p. 10).

É uma perspectiva em constante construção, de fluxos relacionais, e tem ganhado múltiplas propostas investigativas, a partir das diferentes visões e experiências de pesquisadores dedicados a essa "proposta aberta" da comunicação, a exemplo dos trabalhos desenvolvidos por Gilson Vieira Monteiro, fundador do PPGCCOM e de Mirna Feitoza Pereira, com pesquisas guiadas pelo viés da semiótica.

Conceitos e quadros teóricos, a exemplo da Teoria Geral dos Sistemas (Ludwig von Bertalanffy); do Pensamento Complexo (Edgar Morin); Ecologia Profunda (Fritjof Capra); Ecossistema Comunicativo (Educomunicação); NovoSensório(Walter Benjamin); Semiosfera (Yuri Lotman); Rizoma (Gilles Deleuze e Felix Guattari); entre outros, tangenciem, inspirem e se incorporem ao viés ecossistêmico proposto pelo PPGCCOM, que ao reforçar a suplementação do ambiente amazônico, apresenta-se como uma abordagem diferenciada das demais.

Para Colferai (2014) a Amazônia é a própria metáfora de um ecossistema comunicacional. $O$ autor propõe uma aproximação que se articula considerando a corporeidade das relações, as tecnologias, as subjetividades sociais, culturais e o ambiente. Para desenvolver sua tese ecossistêmica, Colferai (2014) recorreu a conceitos formulados pelos biólogos chilenos Francisco Varela e Humberto Maturana, como enação, ao considerar a inseparabilidade entre ser humano e natureza, e autopoiese, ou seja, a capacidade dos sistemas vivos e suas estruturas estarem em constante autoprodução e autorregulação, mantendo interações entre seus próprios elementos e na relação com outros sistemas, além do pensamento complexo, do filósofo Edgar Morin, e da ecologia dos saberes, do sociólogo Boaventura Sousa Santos, em favor de uma ciência não paradigmática.

Desse modo, conforme Colferai (2014), há uma plasticidade favorável à conexão entre ser humano, ambiente e aparatos tecnológicos, e o que vemos, ouvimos e sentimos (seja na experiência real ou virtual, individual ou na interação social, pelas telas de TV, celulares, ipods, jogos eletrônicos e etc.) provocam reações no sistema nervoso criando novas conexões neuromusculares e cognitivas, fazendo com que os aspectos biológicos, psíquicos, sociais, do ambiente e o aparato tecnológico tornem-se pontos de conexão em simbiose. É nessa dinâmica, segundo o autor, que se proporciona a expansão de corpos e sentidos, por atuações diversas e complexas. A compreensão de ecossistemas comunicacionais implica ter essa flexibilidade de entendimento e percepção e, por isso, quem se propõe a pesquisar por esse viés não deve pensar, necessariamente, em uma aplicação prática, mas exercitar a busca de multiplicidades, permitindo que a criatividade e os afetos ganhem espaço na produção do conhecimento científico.

\section{As imensuráveis dimensões da Arte}

A Arte também é comunicação e representação, além de inúmeras definições técnicas, filosóficas, estéticas, metafísicas... Antes de atribuir o caráter artístico a determinadas manifestações ou sistematizar códigos formais para a linguagem verbal ou escrita, os seres humanos já simbolizavam por gestos, dançavam, desenhavam, esculpiam, produziam sons, elaboravam construções, praticavam rituais...

Portanto, as expressões artísticas e as formas de comunicação foram se estabelecendo nas relações com o meio, pelas possibilidades materiais e pelo desenvolvimento do processo cognoscível e da consciência reflexiva, que se transformaram ao longo do tempo e, conforme Santaella (2005), esse transcurso proporcionou a criação de linguagens para organizar o pensamento afetado pelos sentidos. Sendo assim, num lento e complexo processo, foram sendo aprimoradas a qualidade de gestos, sons, 
palavras, figuras simbólicas, a ativação de memórias, a relação com os outros seres e com o ambiente. Portanto, organizando diferentes combinações, códigos e linguagens, entre elas a arte. E, na arte, inúmeras linguagens artísticas.

Nessa medida, o termo linguagem se estende aos sistemas aparentemente mais inumanos como as linguagens binárias de que as máquinas se utilizam para comunicar entre si com o homem (linguagem do computador, por exemplo), até tudo aquilo que, na natureza fala ao homem e é sentido como linguagem. Haverá, assim, a linguagem das flores, dos ventos, dos ruídos, dos sinais de energia vital emitidos pelo corpo e, até mesmo, a linguagem do silêncio. Isso tudo, sem falar do sonho que, desde Freud, já sabemos que também se estrutura como linguagem (SANTAELLA, 2005, p. 11-12)

Logo, as linguagens são meios de comunicação e representação articuladas na imbricação de sistemas e, consequentemente, desencadeando novos processos de representação, ou processos signícos. Santaella (2001) traz da fenomenologia um questionamento importante: como se dá a apreensão e compreensão do mundo pelo ser humano? Segundo a autora, embasada na semiótica de Peirce, não há pensamento sem signos, que por sua vez dependem de uma interpretação para existirem, e isso ocorre pela qualidade do sentimento, ação e reação, e mediação. De acordo com Santaella (2003) o ser humano só concebe o mundo porque de alguma forma o representa e, consequentemente, só interpreta tal representação por meio de outra representação. Esse processo, pode ser gerado a partir de imagens mentais ou palpáveis, pelo gestual, por ações, sons, palavras, sentimentos etc.

No percurso signo-significação-representação, segundo Santaella e Nöth (1999), tudo o que se apresenta às percepções e ao intelecto, de forma material ou em pensamento, pode ser signo. A ação do signo, ou seja, a semiose, proporciona uma significação que vai gerar uma representação. Isto é, o signo representa a ideia de uma coisa e não a coisa em si.

Essa concepção pode ser melhor compreendida pela relação triádica da semiótica peirceana, que se constitui na triangulação signo-objetointerpretante, de acordo com Santaella e Nöth (1999). O signo representa alguma coisa para alguém, criando em sua mente um signo equivalente. Nessa operação, gera-se um interpretante e aquilo que o signo representa é denominado seu objeto.
Portanto, a representação ou o processo representativo caracteriza-se pela inter-relação entre signo-objeto-interpretante. Assim, conforme Santaella e Nöth (1999), os pensamentos se processam por meio de signos continuamente, fazendo com que as dimensões da cognição, da comunicação e da representação relacionem-se numa cadeia infinita de semiose.

Para aproximar essa ideia do campo da Arte, podemos começar imaginando uma volta aos tempos pregressos, por meio de um exercício arqueológico da história antropológica, sobretudo, pela análise e compreensão de fragmentos do passado que nos foram legados pela perpetuação de registros visuais. Conforme Prous e Ribeiro (2007) os vestígios evidenciados nos artefatos e pinturas rupestres de milhares de anos atrás, em sítios arqueológicos espalhados pelo mundo, possibilitam estabelecer possíveis significados e correlações, mas é praticamente improvável atribuir certezas para um contexto tão complexo.

Pode-se supor que os registos pré-históricos feitos antes da invenção da escrita, com a representação discursiva-visual de cenas cotidianas (de caça, guerra, dança, sexualidade etc.) ou simbologias míticas (concepções sobre a vida e a morte, por exemplo), por meio de desenhos ou ilustrações figurativas, manchas ou traços, estavam relacionados à consciência mágica da realidade e fins ritualísticos. O que é inegável, segundo Prous e Ribeiro (2007), é que nesse fluxo de representações há uma série de interlocuções por meio de significados simbólicos.

Nesse sentido, tais registros ("origens das artes visuais"), além de configurarem-se por processos sensórios-cognitivos, em função da presença humana nos mais diversos ambientes e contextos para sua produção e percepção, constituemse como um sistema de grande importância do ponto de vista histórico, social, cultural e artístico, estabelecendo um arco espaço-temporalcomunicativo que conecta desde as pinturas rupestres realizadas por nossos ancestrais aos grafites e pichações da paisagem urbana contemporânea, pois a arte carrega memórias em metamorfose desde tempos imemoriais.

O tempo e os símbolos que distanciam historicamente as diversas apropriações dos 
espaços e suportes, podem configurar diferentes significados conforme os momentos evolutivos da espécie, além da gama de diferenças culturais e interesses que se expandiram e modificaram-se ao longo dos séculos. Todavia, mantém uma ligação fundamental e universal que é a necessidade de expressão, seja para manifestar a interpretação da experiência vivida ou imaginada, para perpetuar conhecimentos e informações, pela fruição, transgressão ou quaisquer outras possibilidades que se convergem para a vontade de comunicar, que é um comportamento interativo por natureza. A arte é e sempre foi um dos principais elementos da comunicação humana, como aponta Littlejohn (1988, p. 18), que amplia ainda mais a discussão ao enfatizar que "a arte é um processo de descoberta e um caminho muito pessoal para a verdade".

Refletir sobre teorias e conceitos a respeito da arte é um exercício que exige paciência e despojamento. Janson (1996) explica que a palavra "arte" do latim ars corresponde ao termo grego téchne, ambos podem ser traduzidos como as técnicas ou os meios para se criar, fabricar ou produzir algo, o que pressupõe atividades submetidas à regras e, portanto, do ponto de vista semântico em oposição ao natural, livre e espontâneo. Entretanto, segundo o autor, na contemporaneidade, arte é um conceito subjetivo e gasoso, pois varia tanto na forma de ser produzida quanto na forma de ser interpretada, resultando de percepções culturais, valores e anseios humanos.

De modo que não pode ser lida e compreendida de forma linear, como se a memória, o imaginário e a cultura não fossem aspectos fundamentais na constituição de linguagens simbólicas. Paes Loureiro (2007), inclusive, considera que a cultura é um meio de significação da arte.

É matéria em que o artista modula sua criação, uma vez que por meio dessa ambiência criada é que o homem vive e transvive a realidade. 0 real nos coloca diante da objetividade prática de viver. O imaginário nos garante as aventuras de sonhar. (PAES LOUREIRO, 2007, p. 17)

A arte é um tema amplo e complexo para ser explorado, a julgar pelo universo da música, da literatura, da pintura, entre outras expressões, portanto, vamos tratá-la de forma contextual, pois a intenção desta comunicação não é o aprofundamento epistemológico-teórico. Entretanto, precisamos compreender que as concepções sobre manifestações artísticas, representadas em inúmeras linguagens, ao logo da história da humanidade, foram sofrendo alterações e ressignificações.

No senso comum, expressões como pintura, arquitetura, escultura, paisagismo, moda, design, decoração, teatro, cinema, dança, etc., podem ter apenas o objetivo de ser "agradável aos olhos", proporcionando prazer ou fruição estética. Porém, a potencialidade da arte e da estética é bem mais complexa, na medida em que a estese afeta diferentes níveis perceptíveis e emocionais, extrapassando simplificações sobre o belo ou o feio. Santaella (2007) diz que "cabe à estética, concebida num sentido muito mais vasto que o de uma teoria do belo, descobrir o que deve ser o ideal supremo da vida humana" (SANTAELLA, 2001, p. 38).

Portanto, há um amplo panorama a ser percorrido para compreender que a arte envolve aspectos da dimensão humana, de contextos históricos e socioculturais, interesses políticos e econômicos, aperfeiçoamentos tecnológicos e mobiliza transformações paradigmáticas. No campo da semiótica, segundo Santaella (2001), a arte é uma linguagem polissêmica, ou seja, de inúmeras linguagens e estéticas, que traz características tanto das percepções do mundo físico quanto das elaborações mentais.

Portanto, é uma ação sígnica mediada, não é mera reprodução ou equivalência do juízo perceptivo, mas uma espécie de tradução conceitual que adquire forma (seja figurativa, simbólica ou abstrata), conteúdo e subjetividades a partir do meio e dos suportes materiais na qual é representada. A exemplo da gravura, do grafite, da fotografia, da ópera, do cinema e assim por diante, que apresentam peculiaridades em seus contextos e aparatos. Conforme Santaella (2001) a não linearidade dos nossos processos cognitivos em sua evolução histórica, desdobrados a partir das combinações e misturas entre diferentes linguagens, faz com que "as camadas da criação humana vão se superpondo, formando um agregado cada vez mais espesso em processo de crescimento vetoriados para a complexidade" (SANTAELLA, 2001, p.95).

Desse modo, compreender e interpretar implica em traduzir signos em outros signos, num movimento inter-relacional e ininterrupto do pensamento. Esse fluxo, de signos em transformação, carrega linguagens artísticas 
reconfiguradas e ressignificadas no tempo e no espaço. Paes Loureiro (2007) denomina de "conversão semiótica" o ponto de encontro ou momento de fusão pelo qual objetos, sujeitos, situações culturais ou ideias se reorganizam.

O homem vive a remodelar de significações a vida, a fazer emergir sentidos no mundo em um processo de criação e reordenação continuada de símbolos intercorrente com a cultura. Vai redimensionando sua relação com a realidade num livre jogo com as situações e tensões culturais em que está situado. O homem cria, renova, interfere, transforma, reformula, sumariza ou alarga sua compreensão das coisas, suas ideias, por meio do que vai dando sentido à sua existência (PAES LOUREIRO, 2007, p. 11).

A partir da capacidade de relacionar, segundo Paes Loureiro (2007), o ser humano observa o mundo e o transforma, construindo e reconstruindo relações simbólicas. No caso das artes, ao mesmo tempo em que essa linguagem polissêmica carrega camadas simbólicas e subjetivas também apresenta variáveis físicas.

Conforme Paes Loureiro (2007), ao simbolizar, ou seja, ao representar ou exprimir simbolicamente, o ser humano renova e desenvolve as relações com a realidade.

O próprio Leonardo da Vinci, no Renascimento, refere-se a essa capacidade simbolizadora do olhar, quando indica que a mente humana é um laboratório onde o material recolhido pelos olhos, ouvidos, etc., é transformado em várias faculdades, como a memória (PAES LOUREIRO, 2007, p. 14).

Esse ato de simbolizar é resultado de heranças culturais, pois "há uma relação intercorrente da criatividade individual com esses conjuntos de valores materiais e espirituais universais que se acumulam no trajeto antropológico do indivíduo e em sua prática histórico-social" (PAES LOUREIRO, 2007, p. 17).

Ao fazer uma análise da história da arte, Paes Loureiro (2007), a compreende como um grande mosaico de conversões semióticas, promovidas por sucessivas transgressões aos padrões vigentes, considerando a metamorfose dos processos e das significações desde a pré-história, passando pela antiguidade clássica, pela idade média até os dias atuais, pressupondo ciclos cada vez mais rápidos e remixados. Conforme o autor, essa conformação assimétrica de mestiçagens, pode ser percebida na transformação das chamadas belas-artes (compreendidas como o ramo erudito da arte) em expressões consideradas banais, a exemplo de Marcel Duchamp ao transformar objetos do cotidiano (como rodas de bicicleta e urinóis) em obra de arte, ou de Andy Warhol ao dar a arte uma faceta publicitária, ou ainda nas inúmeras possibilidades de fazer com que as manifestações artísticas tornem-se procedimentos de alcance popular, com a incorporação de técnicas ou linguagens que corroboram para um painel polissêmico, como nas instalações ou nas performances, que podem ser compostas por pinturas, vídeos, textos, corpos, materiais orgânicos, etc.

\begin{abstract}
A imediatidade e a globalidade atual da informação vêm apagando a chama da concepção linear da evolução artística. Com isso, ocorre o fim da unidade nas belas artes coetânea à avalanche de novos materiais e práticas artísticas, promovendose a constelação da heterogeneidade e de "transsemiotização" perene em um mundo dinâmico e heterogêneo. (PAES LOUREIRO, 2007, p. 19)
\end{abstract}

Portanto, Paes Loureiro (2007) sugere que a conversão semiótica é um processo de transfiguração que acompanha a humanidade desde tempos imemoriais, sendo mediação no processo das construções culturais e das significações na arte. Entretanto, torna-se mais perceptível na pósmodernidade, marcada pela pluralidade de estilos e multiplicidade de linguagens e códigos.

\begin{abstract}
Além disso, tão importantes quanto as obras são as atitudes e posturas artísticas. O discurso. A individualização de processos, embora, muitas vezes, com tendência à banalização. Diante dos novos paradigmas, o processo de conversão semiótica se mantém incólume, uma vez que significa um mundo de mudança na qualidade do signo, independente de época ou tendências, sendo válido tanto no passado como no presente. Porém, ele se torna mais evidente no mundo atual pela densificação do dinamismo das mudanças e, logo, epstemo e heuristicamente, como um conceito fundamental. Pois é, em si, "multi" (PAES LOUREIRO, 2007, p. 21).
\end{abstract}

\section{Corpo, mente, ambiente em processos de criação artística}

Inspiração, técnica, dedicação? Não há fórmulas ou caracterizações definitivas para explicar os processos da criação artística, já que no fluxo desse processo comunicativo há tantas variáveis que a razão se esgota em limites conceituais, dando a essa prática inerente ao homem outras possibilidades de acesso e entendimento.

Ao entrarmos na discussão sobre esse inquietante e dinâmico processo, acreditamos que seja importante 
termos algumas noções sobre aspectos relativos aos sistemas sensórios e cognitivos do ser humano, e sobre as implicações na relação do corpo, mente, da cultura e da tecnologia com o ambiente, suas inter-relações e interconexões.

No fluxo intercambiante de memórias mentais e corporais, Sacks (1997) salienta que o cérebro é capaz de criar inúmeras realidades e de se adaptar a elas, por vezes provocando curiosas conexões entre alucinação, memória e realidade, bem como a ativação de talentos artísticos, que podem eclodir a partir de percepções, gestos, deslocamentos no espaço, reflexões pessoais, etc.

Para o físico teórico norte-americano Leonard Mlodinow (2013) é preciso compreender a influência dos instintos inconscientes, abaixo da superfície da mente, que se escondem nos sujeitos, para entender o comportamento social e o mundo ao nosso redor, pois a memória e a imaginação são de extrema importância para a construção, compreensão e comunicação em torno do que concebemos por realidade. Para o autor "ao contrário dos fenômenos da física, na vida, os eventos com frequência podem obedecer a uma teoria ou a outra; o que acontece na verdade pode depender muito da teoria em que escolhemos acreditar" (MLODINOW, 2013, p. 258).

A preocupação em distinguir consciente de inconsciente acompanha os filósofos desde a antiguidade, mas conforme Mlodinow (2013) só a partir do século XIX é que os cientistas passaram a dar mais atenção aos estudos envolvendo a fisiologia e a psicologia. Desde então, os estudos evoluíram e hoje, com os progressos da ciência, é possível mapear rotas complexas realizadas pelo cérebro. Conforme Mlodinow (2013) estima-se que apenas $5 \%$ de nossas funções cognitivas sejam conscientes o restante é inconsciente, porém, esses 95\% exercem influência subliminar em nossos atos e pensamentos, por isso, é impossível dissociar a importância dos sentimentos e das vivências para a cognição.

A evolução nos deu uma mente inconsciente porque é ela que permite nossa sobrevivência num mundo que exige assimilação e processamento de energia tão maciços. Percepção sensorial, capacidade de memória, julgamentos, decisões e atividades do dia a dia parecem não exigir esforço - mas isso só porque o esforço demandado é imposto sobretudo a partes do cérebro que funcionam fora do plano da consciência (MLODINOW, 2013, p. 31).
Segundo Mlodinow (2013) outras espécies animais também apresentam atividades cerebrais em níveis conscientes e inconscientes, mas, no caso da espécie humana a necessidade de interação social foi propulsora para a evolução da inteligência. Conforme o autor, diferente de outras espécies, a capacitação do ser humano para o comportamento social, é decorrente da conformação genética que caracteriza a espécie humana há cerca de 50 mil anos, quando os indivíduos começaram a pescar, caçar e perseguir animais ferozes no intuito de lutar em coletividade pela sobrevivência.

Mais ou menos na mesma época, começaram também
a construir estruturas para abrigo e a criar arte
simbólica e complexos sítios funerários. De repente
descobriram como se juntar para caçar mamutes
lanudos e começaram a participar de cerimônias e
rituais que são os rudimentos do que hoje chamamos
de cultura. Num breve período de tempo, o registro
arqueológico de atividades humanas mudou mais do
que havia se alterado no 1 milhão de anos anteriores
(MLODINOW, 2013, p. 76).

O autor nos indica que essa transformação começou a conformar as bases da cultura, da complexidade ideológica e cooperação coletiva da sociedade, do mesmo modo que nela podem estar as raízes da arte e a gênese do processo criativo. Contudo, tratar da arte e da criatividade, por si só, é uma tarefa hercúlea, e neste momento vamos discutir apenas alguns aspectos que envolvem processos criativos e comunicativos, portanto, nossa abordagem é um pequeno recorte de um universo riquíssimo e que pode ser explorado por diferentes perspectivas.

A percepção estética, por exemplo, pode provocar efeitos reverberados no corpo todo, a partir das sensações captadas pelo entorno, muitas vezes regidas por leis da física, como, a percepção das cores, que está relacionada à ótica (pela interação da luz com a matéria), ou aos sons detectados pelo ouvido que chegam por ondas sonoras e que podem provocar uma série de imagens mentais, conforme Santaella (2001). Todos esses processos perceptivos são codificados em processos fisiológicos, psíquicos e químicos pelo cérebro, seguindo às leis da natureza e posteriormente ressignificados.

Desse modo, percebemos a importância do "corpomente"3 e do ambiente como uma força motriz no ciclo comunicacional e na criação artística. Para Greiner (2005) o corpo não é apenas um recipiente e transmissor de informações, mas um organismo transformador em constante 
evolução pela contaminação entre o fluxo informacional que percorre seu contexto sensitivo interno e externo. As experiências decorrentes dessas relações geram comunicação, percepção e relação. A autora propõe pensar o corpo como um sistema complexo e interativo e não apenas como um instrumento, com um lado biológico e outro cultural, ou material e mental.

Possivelmente, essa dicotomia tenha explicação na gênese etimológica da palavra corpo, segundo Greiner (2005), ao explicar que, do latim, corpus ou corporis se referem ao corpo morto, em oposição a alma ou ânima que expressa o corpo vivo. A autora aponta evidencias que conectam o processo coevolutivo do corpo e do ambiente com exemplos de fluxos conectivos entre nações, línguas e culturas, redefinindo os mapas de "fronteiras dramáticas" das "geografias imaginativas". Isso porque o corpo é provido de uma dramaturgia que dá sentido e coerência ao fluxo incessante de informações entre o corpo e o ambiente.

O modo como ela se organiza em tempo e espaço é também o modo como as imagens do corpo se constroem no trânsito entre o dentro (imagens que não se vê, imagens-pensamentos) e o fora (imagens implementadas em ações) do corpo organizando-se como processos latentes de comunicação (GREINER, 2005, p. 73).

Em relação a arte, Greiner (2005) diz que o corpo muda cada vez que percebe o mundo, despertando metáforas mutantes que geram novas ações, caracterizando um "corpo artista" a partir da inspiração na hipótese levantada pelo neurocientista Vilayanur Ramaschandran, para quem a arte (como fenômeno mental) teria uma função fundamentalmente necessária para sobrevivermos. "Assim como a atividade sexual e a experiência da morte (próxima ou anunciada), a atividade estética representaria em nosso processo evolutivo, uma ignição para a vida" (GREINER, 2005, p. 111).

Ao buscarmos ampliar as possibilidades de interpretar aspectos relacionados às interconexões comunicacionais, em fluxos criativos na arte, acreditamos ser fundamental a compreensão de Salles (2010 e 2012), pois a autora defende que o artista, por meio de seus filtros e sua sensibilidade, interpreta e representa o mundo a medida em experimenta determinadas sensações, incorpora percepções do mundo ao seu redor, interage com a memória, reorganiza experiências passadas e permite a fabulação.

Salles (2012) argumenta sobre a importância de analisar os registros materiais dos processos e métodos da produção artística para compreender o percurso criativo dos artistas. Segundo a autora, a arte é uma sequência de agregações de ideias com possibilidades infinitas em permanente mutação um "gesto inacabado".

É um processo em mobilidade e metamorfose sempre aberto à introdução de novas ideias, no qual todo o processo criativo é um ato comunicativo. A arte carrega as marcas singulares de cada artista, mas é um universo amplo, em construção contínua de uma grande cadeia sistêmica. Assim, "o projeto poético de cada artista insere-se na frisa do tempo da arte, da ciência e da sociedade em geral" (SALLES, 2012, p.42).

O artista desenvolve seu trabalho a partir de intrincadas relações em rede, criando obras em movimento, conceitualmente abertas e flexíveis, recebendo influências diversas, seja por imagens, relacionamentos, lembranças, fatos marcantes. 0 ambiente também exerce uma relação complexa e um papel determinante no processo de criação.

A criação como rede pode ser descrita como um
processo contínuo de interconexões instáveis,
gerando nós de interação, cuja variabilidade
obedece a alguns princípios direcionadores. Essas
interconexões envolvem a relação do artista com seu
espaço e seu tempo, questões relativas à memória,
à percepção, recursos criativos, assim como os
diferentes modos que se organizam as tramas do
pensamento em criação. Oartista deixa rastros desse
percurso nos diferentes documentos do processo
criativo (SALLES, 2010, p. 215).

Nesse sentido, Salles (2010) acredita que o processo de criação é uma manifestação comunicacional, ao relacionar o diálogo do artista com ele mesmo e suas ideias, com a materialidade da obra em criação, sua trama de experimentações, com os expectadores, com a crítica, enfim, estabelece um circuito de interlocuções espaço-temporais que vão gerar transformações e ressignificações.

Desse modo, a observação e a sensibilidade são fundamentais para captar os fluxos comunicacionais da arte. É necessário um olhar inter-relacional, porque a ação artística não é linear, tem ritmos, picos, curvas e nós. Uma construção que vai se tramando em processos contínuo de interconexões e interações no tempo e no espaço, através de um 
percurso singular que "é feito de palavras, imagens, sons, gestualidades etc." (SALLES, 2010, p.102).

Diante disso, ao apresentarmos essa aproximação entre comunicação e da arte, procuramos ampliar as possibilidades de reflexão e leitura acerca de objetos e processos da realidade sociocultural, iluminando caminhos não trilhados, propondo outros olhares e metodologias, frente aos fenômenos que exigem maior plasticidade nas abordagens investigativas e, assim, criando novas perguntas e significados para configurações culturais-artísticas-comunicacionais, em contínuos fluxos semióticos.

\section{NOTAS}

1. Disponível em: <http://www.ppgccom.ufam. edu.br/index.php/apresentacao> Acesso em: 18 mai. 2016.

\section{Disponível em:}

<https://sucupira.capes.gov.br/sucupira/ public/consultas/coleta/propostaPrograma/ listaProposta.jsf> Acesso: em 18 mai. 2016.

3. Estamos trabalhando com a ideia de "corpomente" e ambiente, a partir da Teoria Corpomídia, formulada pelas pesquisadoras Christine Greiner e Helena Katz, do Centro de Comunicação das Artes do Corpo, vinculado ao Programa de Pós-Graduação em Comunicação e Semiótica da PUC-SP, que propõe pensar o corpo como um organismo ecológico, ou seja, inseparável da relação com o seu ambiente. Segundo Greiner (2005) o corpo é sujeito físico, mental e ambiental, pois está em permanente processo de evolução com o ambiente natural e cultural em que se insere, contrapondo-se a noção cartesiana na qual corpo, mente e ambiente estão dissociados.

\section{REFERÊNCIAS}

CAPRA, Fritjof. As conexões ocultas - ciência para uma vida sustentável. São Paulo: Cultrix, 2002.

COLFERAI, Sandro Adalberto. Um jeito amazônida de ser mundo. A Amazônia como metáfora do ecossistema comunicacional: uma leitura do conceito a partir da região. Tese (Doutorado em Sociedade e Cultura na Amazônia). Universidade
Federal do Amazonas, Programa de Pós-Graduação em Sociedade e Cultura na Amazônia. Manaus: UFAM, 2014.

GREINER, Christine. O corpo, pistas para estudos indisciplinares. São Paulo: Annablume, 2005.

JANSON, Horst. História da Arte. São Paulo: Martins Fontes, 1996.

LITTLEJOHN, Stephen. Fundamentos teóricos da comunicação humana. Rio de Janeiro: Editora Guanabara, 1988.

MLODINOW, Leonard. Subliminar - Como o inconsciente influencia nossas vidas. Rio de Janeiro: Zahar, 2013.

MONTEIRO, Gilson Vieira; ABBUD, Maria Emília de Oliveira Pereira; PEREIRA, Mirna Feitosa (orgs.). Estudos e perspectivas dos ecossistemas na comunicação. Manaus: Edua/Ufam, 2012.

PAES LOUREIRO, João. A conversão semiótica: na arte e na cultura. Belém: Edufpa, 2007.

PROUS, André; RIBEIRO, Loredana. Arte Rupestre Pré-histórica: imagens fixas, significados mutáveis. Curitiba: Zencrane, 2007.

SACKS, Oliver. o homem que confundiu sua mulher com um chapéu e outras histórias clínicas. São Paulo: Cia. das Letras, 1997.

SALLES, Cecília Almeida. Gesto inacabado: processo de criação artística. São Paulo: Intermeios, 2012.

SALLES, Cecília Almeida. Arquivos de Criação: arte e curadoria. São Paulo: FAPESP/ Ed. Horizonte, 2010.

SANTAELLA, Lucia. Culturas e artes do póshumano: da cultura das mídias à cibercultura. São Paulo: Paulus, 2003.

SANTAELLA, Lucia. Matrizes da linguagem e pensamento: sonora, visual, verbal. São Paulo: Iluminuras/FAPESP, 2001.

SANTAELLA, Lucia. 0 que é semiótica. São Paulo: Brasiliense, 2007.

SANTAELLA, Lucia. Semiótica aplicada. São Paulo: Pioneira Thomson Learning, 2005

SANTAELLA, Lucia; NÖTH, Winfried. Imagem, 
cognição, semiótica e mídia. São Paulo: lluminuras, 1999.

\section{SOBRE OS AUTORES}

Ítala Clay de Oliveira Freitas é bailarina e jornalista. Graduada em Comunicação pela Universidade Federal do Amazonas, mestre em Comunicação e Semiótica: Artes, e doutora em Comunicação e Semiótica: Signo e Significação nas Mídias, pela Pontifícia Universidade Católica de São Paulo. É docente da Faculdade de Informação e Comunicação da UFAM e tutora do Programa de Educação Tutorial de Comunicação Social. Também é docente do Programa de Pós-Graduação em Ciências da Comunicação da UFAM, onde coordena a linha de pesquisa em Linguagens, representações e estéticas comunicacionais.

Rafael de Figueiredo Lopes é ator, produtor audiovisual e jornalista. Doutorando em Sociedade e Cultura na Amazônia e mestre em Ciências da Comunicação pela Universidade Federal do Amazonas, e bacharel em Comunicação Social pela Universidade Federal de Roraima. Como pesquisador vem trabalhando principalmente nos seguintes temas: ecossistemas comunicacionais, cinema, estética, Amazônia, processos socioculturais, imaginário e semiótica. 


\section{A ANGÚSTIA DA INFLUÊNCIA NAS ARTES VISUAIS, COMO NA LITERATURA, COM HAROLD BLOOM}

\section{Maria do Céu Diel Oliveira Escola de Belas Artes}

\section{Resumo}

Estes escritos buscam entender a possibilidade de migrar as categorias poéticas elencadas por Harold Bloom na Angustia da Influência ${ }^{1}$ - clinamen, tessera, kenosis, demonização, askesis e apófrades para as artes visuais como forma de entendimento, compreensão e superação da influencia poética/ artística. Assim, acredito que as mesmas categorias de Bloom para a literatura podem ser escopo de processo criativo nas artes visuais.

\section{Palavras-chave:}

Bloom, Angústia da Influência, artes visuais, poesia.

\section{CLINAMEN}

Escreveu Harold Bloom,

..." os poetas fortes fazem a história lendose mal uns aos outros, de modo a desobstruir um espaço de imaginação para si próprios. " (Bloom, 1991, p.17)

O que poderíamos entender na expressão ler-se ma? Escrevendo sobre teoria da poesia, Bloom propõe a existência do poeta forte e de todos aqueles que seguem sob sua égide. Apresenta então as formas como a poesia e seus criadores geram um generoso numero de seguidores e de como estes - conscientes desta influência - buscam a seus espaços de criação, ou nas palavras de Bloom, um desvio (idem, p.57). A influência angustiante é semelhante ao inferno na existência da arte. Arrastado pela irresistível presença do poeta forte, do artista dominante, em um círculo de outros poetas igualmente poderosos, resta ao artista ler mal: ler/ ver/ouvir o poeta de forma a permitir cacofonias, ruídos, manchas, brechas ou outras formas de infiltração de matéria poética, de substâncias contaminadoras de sua própria vida até então. Não se trata de uma forma de rejeição, de negar
Abstract

These writings seek to understand the possibility of migrating the poetic categories listed by Harold Bloom in Anguish Influence - clinamen, Tessera, kenosis, demonization, askesis and apofrades - for the visual arts as a way of understanding, understanding and overcoming the poetic / artistic influence. Thus, I believe that the same categories of Bloom for literature can be creative process scope of the visual arts.

Keywords:

Bloom, influence anguish, visual arts, poetry.

a dívida com o poeta forte, mas de entendimento da sobrevivência de ambos na memória de quem está vivo e criando. Percebo, portanto, que certos artistas se aproximam de outros cuidadosamente, num embate que ondeia entre o arrebatamento e a razão. Desta luta frutificam as camadas de construção de entendimentos, num ondejamento de adesão e descolamento. Aproximar-se, afastar-se, mergulhar, friccionar-se na obra do artista forte são movimentos que produzem ferimentos e cicatrizes, que preparam a pele de seu corpo criativo para outras provações. Fortalecidos na troca imaginal, os artistas admiradores de artistas fortes tornam-se também fortalezas, emanando em suas imagens/ textos/vozes direções e sentidos para onde outros seguirão, tateando, dedilhando, escarificando sua própria pele para nela perceber outros organismos, outras imagens corporificadas, fragmentos do artista forte. Escolha estética como escolha política, os artistas fortes que lêem/vêem/ouvem outros fortes enxergam-nos astigmaticamente para poderem sobreviver e encontrar-se mais tarde, transformados, desviados. 
Proponho então a migração desta teoria poética para as artes visuais, na medida em que uma leitura desfocada de um artista por outro pode produzir uma alucinação de entendimento, uma crítica e uma curva em direção a outras imagens.

Lemos em Bloom:

"Kierkegaard, em Temor e Tremor anuncia, com uma confiança magnífica, mas absurdamente apocalíptica que' aquele que está disposto a trabalhar, dá a luz ao seu próprio pai"' Continua, ao definir angústia segundo Freud: "A angústia antes de alguma coisa é claramente um modo de expectativa, como o desejo. (...) A angústia da influência é uma angústia quanto à expectativa de ser inundado. " Mas anuncia também o perigo pois:

" $E$, no entanto, esta metonímia dificilmente pode evitar-se: todo o bom leitor deseja literalmente afogar-se, mas se o poeta se afoga, tornar-se-á apenas um leitor." ${ }^{3}$

Ainda pensando segundo Freud, que reconheceu que "a sublimação era a conquista humana mais elevada" - sublimação esta caracterizada pelo abandono de modos de prazer mais primordiais a favor de modos mais refinados de prazer, significando exaltar a segunda oportunidade em relação a primeira. 0 sonho abandonado desta realização não é apenas uma fantasia de gratificação interminável, mas antes a maior de todas as ilusões humanas, o sonho da imortalidade.

Geoffrey Hartman ${ }^{4}$ distingue claramente entre prioridade - enquanto conceito da ordem natural - e autoridade, enquanto ordem espiritual. Portanto "ao tentar ultrapassar a prioridade (...) a arte combate a natureza no terreno desta e está destinada a perder". Assim os autores fortes estão condenados, por assim dizer, por esta não sabedoria. Uma empresa auto frustrata, nos dizer de Bloom, não o de "Prometeu, mas do Édipo Cego, que não sabia que a Esfinge era sua Musa." ${ }^{5}$ Batalhas entre iguais fortes, pais e filhos poéticos, Laio e Édipo, o eu poético aboriginal.

Podemos especular que os artistas de todas as épocas contribuíram para uma grande tela em progresso perpétuo. Borges observou que os poetas criam seus percursores. Para este estudo, admitiremos que os poetas/artistas fortes só leem a si próprios. Apontamos uma alegoria de um poeta/artista aido, o Satã de John Milton ${ }^{6}$, o arquétipo do poeta moderno. Bloom explicita que "o Satã se torna fraco quando raciocina e compara". O Paraíso Perdido é então a alegoria do dilema do poeta moderno. Segue a alegoria de Bloom, onde

"Satã é o poeta moderno, enquanto Deus é seu antepassado morto, ou melhor, o poeta ancestral, ainda embaraçosamente poderoso e presente. Adão é o poeta moderno potencialmente forte, embora em seu momento mais fraco, quando ainda não encontra sua própria voz. Deus não tem Musa, e não precisa dela, visto que está morto, manifestandose sua criatividade apenas no passado do poema."

Para acumular estas tantas imagens em tantos anos de vida, é vital que elas se cubram de poeira ou ricocheteiem entre paisagens e construções memoriosas ou que aspirem ao invés de respirarem para que o artista/contemplador possa sobreviver a elas. Assim Bloom lê em Lucrécio:

"Quando os átomos viajam para baixo, movidos pelo seu próprio peso, através do espaço vazio, em movimentos e lugares indeterminados desviam-se ligeiramente do seu curso, apenas o bastante para podermos considerar que houve uma mudança de direção. Não fora este desvio, tudo cairia verticalmente como pingos de chuva através do abismo do espaço. Nenhuma colisão teria lugar e não ocorreria nenhum impacto entre átomos. Assim nunca a natureza teria criado coisa alguma...

Mas o fato da mente não ter ela própria nenhuma necessidade de determinar cada um dos seus atos e forçá-los a sofrer uma passividade impotente deve-se ao ligeiro desvio dos átomos em momentos e lugares determinados." (Bloom, 91, pag 56).

Clinâmen é uma palavra latina que significa "inclinação". Foi o nome usado por Lucrécio para designar a espontânea curvatura dos átomos em uma trajetória vertical enquanto caem. Esta curva, este movimento é um movimento corretivo no próprio poema ou imagem.

Novamente o desvio na queda em direção à imagem forte, desta feita na forma infinitamente pequena da constituição da matéria da existência. Quando evocadas as imagens vividas ou sentidas, é forçoso percebê-las infinitamente fragmentadas, girandoas e acreditando tê-las compreendido, ou melhor, entendê-las da forma como elas também poderiam ser vistas. Então, em cada uma destas imagens de influência haverá uma partícula desviada, incompreendida, renegada, torta. Como folículos de uma pele marcada pelo tempo, onde convivem 
sinais da juventude desviados pelo presente do tempo, estas imagens tornam-se suportáveis e familiares, conformando o artista de sua existência e convívio com elas.

Escreve Malraux - o coração de qualquer jovem é um cemitério no qual se inscrevem os nomes de mil artistas mortos, mas cujos únicos residentes são uns poucos fantasmas poderosos e frequentemente antagonísticos. O poeta é assombrado por uma voz com a qual a palavra tem que se harmonizar. Malraux chega a fórmula - do pastiche ao estilo - que não é adequada a influência poética, pois o movimento de autorrealização encontra-se mais próximo do espírito mais drástico da máxima de Kierkegaard: aquele que está disposto a trabalhar dá a luz a seu próprio pai. Desde Homero que a influência poética é descrita como uma relação filial, mas no lluminismo demonstra-se um produto do dualismo cartesiano.

A palavra "influência" recebeu seu significado de "ter um poder sobre outra pessoa" logo no latim escolástico de São Tomás, mas durante séculos não perdeu seu sentido etimológico de "influxo", seu sentido primordial de uma emanação ou força sobre a humanidade proveniente dos astros. No seu primeiro uso, ser influenciado significava receber um fluxo etéreo proveniente dos astros, um fluido que afetava o caráter e o destino de uma pessoa. Porém a angústia precedeu seu uso. Por imitação, entende-se "ser capaz de converter a substancia ou as riquezas do outro poeta para nosso próprio uso. Fazer a escolha de um homem excelente sobre os demais, e assim segui-lo, até se tornar nele próprio, ou tão como ele como cópia que possa ser tomada por original."

Blake diz: ser escravizado pelo sistema de um percursor é ser inibido da criatividade por um raciocínio e uma comparação obsessivos, presumivelmente entre as próprias obras e as do percursor. Aí reside a natureza de perdas e ganhos da influência no labirinto da história. Blake distingue entre Estados e Indivíduos. Os indivíduos passam através de estados de ser e permaneciam indivíduos, mas os estados estavam sempre em movimento, sempre a oscilar. E só os estados eram culposos, os indivíduos nunca. A influência poética é uma passagem de indivíduos ou particulares através de estados.

Assim, o princípio geral do argumento é: A influência poética - quando diz respeito a dois poetas fortes, autênticos - processa-se sempre através de uma leitura má do poeta anterior, um ato de correção criativa que é realmente e necessariamente uma interpretação errônea. A história da influência poética frutífera, que o mesmo é dizer a tradição da poesia ocidental a partir do renascimento é uma história de angústia, e de caricaturas defensivas de distorções de revisionismos perversos e deliberados sem os quais a poesia moderna não poderia existir.

Mas o que é a influência poética? Pode o seu estudo ser mais do que a indústria enfadonha de caça as fontes, contagens de alusões?

O que dizer da máxima de Emerson: Insiste em ti: nunca imites. Como confrontar-se com o grande original?

O demônio da continuidade é o querubim protetor - ver no gênese os querubins que abriram suas asas para proteger a arca. Continuidade é gestão. Seu encanto pernicioso aprisiona o presente no passado e reduz um mundo de indiferenças a uniformidade acinzentada.

O poeta forte de fato diz: Parece que acabei de cair, agora sou caído e, portanto, aqui estou no Inferno, mas ao dizê-lo pensa: Ao cair, desviei-me portanto estou aqui num inferno melhorado pela minha própria criação?

\section{TESSERA, ou conclusão e antítese}

Bloom rememora o ensaio de Nietzsche Acerca da vantagem e da desvantagem da história para a vida, que leu como estudante em outubro de 1951:

"Podem-se criar as obras mais assombrosas; o enxame de eunucos históricos lá estará sempre no seu lugar, pronto a considerar o autor através de seus compridos telescópios. Ouve-se logo o eco, mas sempre sob a forma de 'crítica' apesar do crítico não sonhar com a possibilidade da obra um momento antes. Nunca chega a ter influência, mas só uma critica e a própria critica não tem influencia, mas gera outra critica. (...) O treino histórico de nossos críticos impedem que tenham qualquer influência no verdadeiro sentido do termo - uma influência sobre a vida e a a ação'B.

Continua a seguir dom a concepção de gênio, no seu Crepúsculo dos Ídolos:

"Os grandes homens, tais como as grandes épocas, são explosivos nos quais se armazena uma força 
terrível: a sua precondição, historicamente e psicologicamente é sempre que, durante muito tempo muito tenha sido coligido, armazenado, guardado e conservado para si - que não tenha havido uma explosão durante muito tempo. Quando a tensão desta massa se tornou demasiadamente grande, basta o estímulo mais acidental para convocar para este mundo o gênio, o ato, o grande destino. Não importam então o ambiente, a época, o espírito do tempo ou a opinião publica."

No nosso estudo sobre a migração da angústia da influência na poesia, poderemos então imaginar que buscamos no artista forte aquilo que amamos em nós, um espelho de si. Goethe escreve que amamos nos outros somente aquilo que lhes empresta, seus próprios eus, a sua versão de si. No mundo das imagens, é possível então que uma influência seja um fato previsível dentro de uma cadeia estética de promessas a nós mesmos como fazedores de imagens? Como Thomas Mann confessa enquanto escrevia o Dr. Faustus, escrevendo em seu diário: Sermos lembrados de que não estamos sozinhos no mundo - sempre desagradável. A imitiatio - ou a perseveração da virtude na vida de outro artista - é um modo de preservação e sobrevida das imagens. Bloom cita Mann, pois ilustra nosso 'século face aos desgostos da influência':

"Que papel o infantilismo - por outras palavras, a regressão a infância - esse elemento genuinamente psicanalítico, desempenha em nossas vidas! Que larga parte tem na formação da vida do ser humano; opera de fato exatamente do modo como descrevi: como identificação mítica, sobrevivência, percorrer das pegadas já existentes! O laço com o pai, a imitação do pai, o jogo de ser o pai e a transferência para figuras substitutas do pai de um tipo mais alto e mais elevado - como funcionam estes traços infantis na vida do indivíduo a marcam e a formam!(...) O artista em especial, um ser apaixonadamente infantil e lúdico, pode informarnos a respeito do efeito misterioso mas afinal óbvio de uma tal imitação infantil sobre sua própria vida, a sua condução produtiva de uma carreira que afinal não é se não a reanimação do herói só condições pessoais e temporais muito pessoais e com meios muito infantis, muito diferentes(...)."

O esquecimento é propriedade de toda ação. A ironia funciona para o artista como uma forma de negação da influência, pois, 'acreditar que chegamos tarde ao mundo é de qualquer modo nocivo e degradante; mas deve parecer assustador e devastador quando diviniza quem chegou tarde, mediante um golpe claro de leme através do qual o verdadeiro significado e o verdadeiro objetivo de toda a criação passada e de todo infortúnio consciente daquele, é disposto como a perfeição da história universal', como protesta Nietzsche.

Voltando a máxima de Kierkegaard sobre 'aquele que estiver disposto a trabalhar dará à luz a seu próprio pai' porém segundo Nietzsche 'quando não temos um bom pai é preciso inventar um'. Quando o artista - aqui, os criadores de imagens, sofre sua encarnação como artista, sente realmente angústia em relação a qualquer perigo que possa acabar com ele como artista. Daí a melancolia, a angústia da influência.

Quintus Curtius Rufus - historiador romano - evoca então as musas tocantemente para auxiliar o poeta a suportar sua memória do futuro:

'Aos poetas chamou-se propriamente de divinos, no sentido de adivinhos, divinari, adivinhar ou predizer. Sua ciência chama-se Musa, definida por Homero como o conhecimento do bem e do mal, isto é, adivinhação... Foi então a Musa a ciência de adivinhar através de auspícios... Urania, cujo nome vem de ouranos, céu, significa aquela que contempla o céu, para deles retirar os auspícios... e outras musas eram filhas de Júpiter - pois da religião nascem todas as artes da humanidade, das quais Apolo, tido principalmente por Deus da adivinhação, é a divindade principal - e cantam, no sentido em que os verbos latinos camere e cantare significam predizer.' O artista engendra de maneira freudiana a possibilidade de ser pai de si próprio, uma profecia e sabedorias sinistras.

Como perseguição de uma influência artística, avançaremos então para a tessera ou vínculo. Na tessera o artista posterior fornece aquilo que sua imaginação Ihe diz que vai completar sua obra. 0 termo tessera vem da observação de Mallarmé que "compara o uso corrente da Linguagem a circulação de uma moeda cujas faces só mostram efígies apagadas e que as pessoas passam de mão em mão, em silêncio." A função da tessera é como uma senha de reconhecimento. A tessera era empregada em religiões de mistério primitivas em que o reajustamento de duas metades de uma peça partida de cerâmica era usado como meio de reconhecimento por iniciados. 


\section{KENOSIS}

A terceira categoria de revisão poética é a Kenosis, ou "esvaziamento" como elenca Bloom, "um movimento da imaginação, de dissolução e isolamento". O termo é retirado da descrição de São Paulo, da "humilhação" de Cristo que de Deus se fez homem. Nos poetas fortes - e para nós aqui, os artistas fortes - a kenosis é um ato de revisão no qual tem lugar um esvaziamento ou um abaixamento em relação ao percursor. Bloom explica que tal esvaziamento é uma 'descontinuidade libertadora' e torna possível um tipo de poema que a simples repetição o afflatus ${ }^{10}$ não poderia permitir. Assim a dissolução do artista forte percursor em si próprio serve ainda para isolar o eu da posição de percursor. Serão, pergunta Bloom, estes mecanismos de defesa semelhantes aos que existem em nossa vida psíquica?

Porque a influencia - que poderia ser uma questão de saúde - é uma angústia? Acreditava-se numa pureza original, impossível de ser tocada pela mera experiência natural. Os artistas fortes devem crer nisto, visto que são, ao dizer de Bloom, "perversos" ${ }^{11}$. Desviar-se então pode ser etimologicamente entendido como 'limpar, limar, polir'. Porém a imaginação do poeta forte não se pode ver como perversa, sua inclinação tem que ser a saúde, a sua prioridade. Se o dom da imaginação provém necessariamente da perversidade do espírito, então 'o labirinto vivo da literatura constrói-se sobre as ruínas de nossos mais generosos impulsos'. Para as coisas e lugares indizíveis da imaginação, a potência da repetição perde-se. 'Não há nomes, diz Valery, para as coisas entre as quais o homem está mais verdadeiramente só'. A crítica aprecia a continuidade, mas aquele que vive da continuidade não pode ser um artista.

Bloom ironiza então o 'deus dos poetas não é Apolo, mas um gnomo careca chamado Ero, que vive nas traseiras de uma caverna (...) e que assoma de seu esconderijo apenas a intervalos regulares para festejar os poderosos mortos na escuridão da lua' (primos são Desvio e Conclusão). São adoradores da continuidade, pois só ali tem alcance. E conclui que 'só o leitor Ideal ou o Verdadeiramente Corrente gosta da descontinuidade e um tal leitor está ainda a espera de nascer ${ }^{12}$ (Hermes envelhece, transformase em Erro e inventa o comércio). As relações inter poéticas não são nem comércio nem roubo.
Bloom então apresenta a noite e a morte, amigas do poeta/artista forte. 'As folhas tornam-se gritos emudecidos e não se ouvem gritos reais'. As continuidades começam com a manhã, mas então nenhum poeta pode ceder a injunção de Nietzsche - tenta viver como se fosse manhã Enquanto poeta, o artista deve viver como se fosse meia noite - uma 'meia noite suspensa'. O lugar e o fato para o artista forte é a sensação de ter sido projetado de forma centrífuga e cadente, em direção ao mar. Instintivamente tenta manter-se na sua borda, mas o impulso antitético o empurra para o interior, para a demanda de fogo. A demanda de fogo é a descontinuidade. A repetição pertence a borda da água - QUE ONDE O ID, O PERCURSOR DO POEMA ESTÁ, FIQUE O MEU POEMA. Mas a repetição pode ser elevada dialeticamente a recriação, mesmo sendo, segundo Freud, uma pulsão de morte enquanto inércia, regressão, entropia. Assim na repetição temos o enunciado da pulsão regressiva, ou morte. Mas Kiergegaard enuncia que 'se o próprio Deus não tivesse querido a repetição o mundo nunca teria podido aceder a existência. Teria ou seguido os leves planos da esperança ou recordado tudo e tudo conservado em memória'. Mas tal não fez e por isso o mundo subsiste devido ao fato de que é uma repetição. A vida que passou torna-se agora. 0 único lugar onde pode o artista ser feliz é na repetição. Mas o poeta forte sobrevive porque vive na descontinuidade de uma repetição dissolvente e isolante. Quando o efebo pede a Musa que o ajude a lembrar do futuro é quase como se pedisse uma repetição. Condenação do percurso a queda em um chão bem duro.

\section{DEMONIZAÇÃO - ou contra-sublime}

O novo artista forte deve reconciliar em si próprio duas coisas - o ethos (identificação) é o daimon (espírito) e "Todas as coisas foram feitas através dele e nada que foi feito foi feito sem ele".

Para Bloom, os poemas emergem não como uma resposta a um tempo presente, mas em resposta a outros poemas. Para Rilke, 'os tempos são resistência'. Para Rilke, a história era o índice dos homens que nasceram cedo demais, mais a arte é o índice dos homens nascidos tarde demais.

Os antigos referiam-se a demônios queriam também referir-se àqueles que pela grandeza de alma também se aproximam dos deuses. Nascer de um íncubo celeste não é senão ter um espírito grande 
e poderoso, muito acima da fraqueza terrena dos homens. $O$ poder que faz do homem um artista é demonico, pois é um poder que distribui e divide - 0 sentido primitivo de daeomai - pois distribui nossos destinos e divide nossos dons, compensando-nos sempre daquilo que nos tira.

Tal divisão traz ordem, confere conhecimento, desordena onde conhece, abençoa com a ignorância para criar uma outra ordem.

Os demônios de Marsilio Ficino ${ }^{13}$ existiram para trazer as vozes dos planetas para homens protegidos. Tais demônios eram a influência, movendo-se de Saturno para o gênio, mais abaixo, transmitindo a mais generosa das melancolias. Em verdade, o poeta forte nunca é possuído por um demônio, mas é ele o demônio, ao menos que enfraqueça e se deixe possuir. Ao voltar-se contra o Sublime do percursor, o novo artista forte sofre uma demonização, um Contra Sublime, que sugere a relativa fraqueza do percursor. Enquanto o novo artista forte é demonizado, seu percursor é humanizado. O Sublime do poeta forte não é o Sublime do leitor a não ser que cada vida de cada leitor divida uma Alegoria. Assim o Sublime do Leitor é o de Burke, um agradável terror. Este leitor cede à simpatia e recusa a descrição, pois precisa ver 0 mais indefinido dos contornos. Na demonização, a consciência poética é ampliada e vê contornos nítidos e devolve a descrição o que tinha cedido a mais à simpatia.

Nesta categoria de revisão poética, o Grande Original permanece grande, mas perde sua originalidade, cedendo-a ao mundo no númen - poder dos espíritos ou deidades presentes nos lugares e nos objetos. Esta é uma guerra de orgulhos, mas a negação do percursor nunca é possível, já que nenhum novo artista forte pode permitir ceder a pulsão de morte, pois a literalidade poética visa a imortalidade literal, e todo poeta pode ser definido como um evitar de uma morte possível.

Como imagens de um movimento em direção a demonização, Bloom aponta uma queda para fora e para baixo, um voo, uma espécie de queda ascendente. Projetado pela glória inebriante de participar da glória do percursor, o artista parece levitar, numa experiência de afflatus que o abandona nas alturas, elevado a extravagância. A ajuda para sair desta extravagância é possível apenas se for uma ajuda exterior. Imagine-se então este artista forte fora do alcance da ajuda e que seria invariavelmente destruído por ela. Desta forma, o artista deve localizar 3 domínios: a paisagem, o eu interior, o olhar do outro. Assim, migrando estes movimentos humanos para os domínios do poema teremos o afastamento, solipsismo ${ }^{14}$ e olhar imaginado do percursor. Portanto, para se apropriar da paisagem do percursor o jovem artista precisa se afastar cada vez mais de si próprio. Para atingir um eu ainda mais interior que seu percursor, o artista torna-se cada vez mais solipsista. Para se furtar ao olhar imaginado de seu percursor, o artista coloca-o ao seu alcance, imaginando um olhar mágico que assiste a todos seus movimentos. 0 olhar desejado é amistoso ou apaixonado, mas o olhar temido é o de reprovação, o que torna o jovem artista forte indigno do amor mais elevado.

Ao mover-se por paisagens mudas, de coisas e lugares que the falam cada vez menos, o jovem artista reconhece também o custo de uma interioridade maior, da separação de tudo o que é extenso. Perde-se a reciprocidade em relação ao mundo, quando comparada com a reciprocidade que o percursor teve em relação ao mundo, a quem todas as coisas falavam.

Partindo da ideia freudiana de que a tradição 'equivale ao material recalcado na vida mental do indivíduo' então a demonização deve aumentar o recalcamento, colocando o percursor ainda mais na tradição que na sua corajosa individuação.

Muito daquilo que chamamos loucura ou o perigoso equilíbrio foi simplesmente o exercício desta perigosa defesa, a demonização. Será esta uma revisão uma ekstasis - este último passo para o além - apenas a intensidade da repressão da imaginação?

Como na visão de Abraão - 'quando o sol se pôs e se estenderam as trevas, eis que uma fogueira fumegante e uma tocha de fogo passaram entre os animais divididos... SOMBRA é bela a palavra de Deus que a ele não volta até que volte a fogueira'.

\section{Askesis ou purgação}

Bloom apresenta nesta quinta categoria a askesis - o ascetismo, ou a sublimação dos instintos pois afirma que 'a sublimação dos instintos de agressividade é central para a escrita e a leitura da poesia e é quase idêntica ao processo de encobrimento poético'. Assim a sublimação poética 
é uma askesis, um modo de purgação, que visa um estado de solidão'.

O poeta forte está então inebriado e consegue 'a um preço terrível' virar toda sua energia para si próprio e vê sua vitória contra os 'poderosos mortos'. De fato, apenas a sublimação pode nos dar uma espécie de 'pensamento liberto do nosso passado sexual' e modificar o impulso instintivo - ou criativo, no nosso caso - sem o destruir. Bloom explicita que os 'poetas em particular (...) são incapazes de existir quer numa frustração prolongada quer numa renúncia estóica'. E pergunta:

“...como podem eles receber o mais fundo prazer, o êxtase da prioridade, do auto-engendramento, de uma autonomia certa, se a sua vida para o Verdadeiro Sujeito e os seus próprios Verdadeiros Eus atravessam o sujeito do precursor e o seu eu? ".

O orfismo, religião natural de todos os poetas enquanto poetas, carrega, segundo Bloom 'uma infelicidade'. Os órficos, que adoram o Tempo como origens de todas as coisas reservavam sua verdadeira adoração para Dionisio, devorado pelos Titãs e renascido de Semele. A infelicidade deste mito está nas cinzas dos 'Titãs pecaminosos'. E continua dizendo que 'todo o êxtase poético, todo o sentimento de que o poeta sai do homem para deus, reduz este amargo mito, como o faz todo o ascetismo poético'.

O jovem artista transformado pela purgação da sua posição de revisão é descendente dos adeptos órficos. Sendo vitima da compulsão à repetição transportava "água com uma peneira para o Hades".

Se pensarmos numa 'filosofia da composição' é necessariamente uma genealogia da imaginação, um estudo da única 'culpa' que importa para o poeta, a culpa da dívida. Assim Bloom evoca Nietzsche quando este diz que 'não há talvez nada mais terrível na história remota de um homem que sua mnemotécnica', pois a intuição associava toda a criação de uma memória a uma dor atroz. Assim Bloom explica que todos os costumes são uma seqüência de processos de apropriação, inclusive as defesas e reações. Assim entendemos esta categoria poética como uma consciência da força do antepassado, promovido ao lugar de deus primitivo. Mas aquilo que os poetas chamam de purgatório, pode ser denominado de sublimação. Esta sublimação pode ser chamada de 'elaboração'. Quando elaboramos tornamo-nos ao mesmo tempo Prometeu e Narciso. Mas para esta contemplação deve fazer um sacrifício, pois 'na medida em toda a criação-por-evasão depende de um sacrifício'. Citando Cornford ${ }^{15}$, Bloom explicita que a humanidade 'aparece' em Hesíodo quando 'Prometeu rouba de seus a melhor parte' e ainda no Gênesis 'o primeiro pecado cometido pela expulsão de nossos primeiros pais do paraíso foi motivado pelos sacrifícios oferecidos por Abel e Caim'. Assim, a escrita e a leitura de poemas são um processo sacrificial, uma 'purgação que esgota mais do que restaura'. Cada poema - ou obra artística no nosso caso - é uma invasão não se de outro poema, mas também de si próprio. Para poder separar a alma do corpo é necessária uma 'internalização', não só um afastamento da alma em relação a si própria mas também de todos os precursores e seus mundos. 'Deformado em cima, deformado para cima' como escreve Bloom, o poeta não pode permitir uma outra kenosis. A askesis 'enquanto defesa eficaz contra a angústia da influência' age como uma espécie de cegueira em relação as outras realidades e exterioridades, até emergir um novo estilo de rudeza, 'com vários graus de solipsismo'. Assim, Bloom explica que na sua askesis purgatorial o poeta só conhece a si próprio e ao outro, seu precursor que finalmente 'deve destruir e que a esta altura pode ser uma figura imaginária, mas ainda formada por poemas passados que não se deixarão esquecer'.

De fato, continua Bloom, 'o clinamem e a tessera tentam corrigir e completar os mortos, a kenosis e a demonização trabalham no sentido de recalcar a memória dos mortos, mas a askesis é a verdadeira 'luta de morte contra os mortos'. E então Bloom nos faz recordar de Dante e seu mestre Virgilio. Quando depois de longa peregrinação e com o desaparecimento de Virgilio para ser substituído por Beatriz, após as inúmeras barreiras e conversas no Inferno, finalmente o poeta é nomeado, quando Beatriz o chama "Dante!".

\section{Apófrades, ou o regresso dos mortos}

Bloom inicia esta categoria citando Empédocles que 'acreditava que nossa psique ao morrer retornava ao fogo de onde tinha vindo'. Mas não o nosso demônio, que nos foi herdado. A genealogia da imaginação traça uma descendência do demônio e 'a obra de um poeta forte pode expiar a obra de um precursor'. Os mortos fortes 
podem 'regressar' quer nos poemas quer em nossas vidas. O poeta forte é vulnerável a esta ultima fase na sua relação de revisão com os mortos. Os apófrades - os dias desoladores e infaustos em que os mortos regressavam para habitar suas antigas casas - acontecem para os poetas fortes, como um 'influxo'. Toda a tirania do tempo é derrubada e pode-se acreditar que 'os poetas fortes estão a ser imitados pelos seus antepassados'. Para discutir esta categoria, Bloom evoca Borges, segundo o qual os artistas 'criam seus precursores'. "Assim, de maneira 'drástica' o poeta forte coloca na sua própria obra o antepassado de forma que 'as passagens concretas da obra deste se pareçam não como presságios de nosso próprio advento, mas serão diminuídas pelo nosso próprio resplendor." Os poderosos mortos regressam, mas regressam nas nossas cores e falam as nossas vozes e (...) testemunham a nossa persistência e não a sua'. Desta forma, Bloom afirma que o deleite do ego maduro 'se reduz ao mistério do narcisismo, aquilo que Freud chama primário e normal - o complemento libidinal do egoísmo do instinto de auto-preservação'. O amor do artista forte por sua arte tem que excluir a realidade de toda a arte restante. Assim os apófrades, quando 'geridos por uma imaginação capaz do poeta forte que persistiu na sua força', tornam-se não apenas o regresso dos mortos, mas uma celebração do regresso, da exaltação de si anterior que tornara antes possível a poesia'.

Bloom evoca Artaud a conclamar que: "Deixem os poetas mortos abrirem o caminho a outros. Poderemos então compreender que é a nossa veneração pelo que já está criado que nos petrifica". É mais importante que os novos artistas/poetas possuam um conhecimento rico. Os precursores inundam-nos, mas nossas imaginações não podem se afogar neles.

\section{Notas}

1. Bloom, H. A Angustia da Influencia, uma teoria da poesia. Ed. Cotovia, Portugal, 1991.

\section{Bloom, ibidem pág 70}

3. Ainda aqui sobre uma teoria da poesia, que desejo transpor para uma teoria da angústia nas artes, inundando-me da possibilidade desta angustia míope.
4. In Bloom, pág 21

5. Bloom, pág 22

6. Lost Paradise, 1667.

7. Bloom, pag 57

8. Bloom, pag, 63

9. Bloom, pag 64

10. Termo latino derivado de Cícero em De natura Deorum, que significa inspiração, ser insuflado pelos deuses.

11. Bloom pag 98. Perverso, no sentido literal, 'virado para o caminho errado'.

\section{Bloom, pág 92}

13. Ficino, médico e astrólogo do século XV (14331499), buscou a síntese entre o pensamento aristotélico e o neoplatonismo cristão. Essa síntese foi colocada a serviço da Astrologia e da Medicina. O propósito expresso de seus esforços era mostrar, ao homem saturnino, alguma possibilidade de escapar dos perigos de seu temperamento e patrono celestial e desfrutar de seus benefícios. Mas sua obra vai muito além de sua intenção original. O sistema desenvolvido por Ficino foi absolutamente revolucionário para o pensamento médico e científico: sem ele, jamais teria surgido o pensamento de Paracelso. Para Ficino, a alma possuía três faculdades distintas que formavam um todo hierarquicamente ordenado: a imaginação (imaginatio), a razão discursiva (ratio), e a razão intuitiva (mens). Só as faculdades inferiores do homem estavam, até certo ponto, sujeitas a influência dos astros; as faculdades da alma, em particular a "mens", eram essencialmente livres.

A influência das forças cósmicas tem que se haver com a consciência individual, o problema astrológico é a questão vital da vontade humana, consciente ou inconsciente: é a questão da eleição ética. 0 humano, ser ativo e pensante, é fundamentalmente livre e pode, inclusive, governar a força dos astros, expondo-se de maneira consciente e voluntária à sua influência. Para tanto, ele propõe uma autoterapia astrológica, uma reordenação deliberada de sua própria razão e imaginação. Essa é a "Magia Natural" de Ficino. 
A obra de Ficino acaba culminando em uma glorificação de Saturno, o Deus-Ancião que renunciou ao mando em troca da sabedoria e trocou a vida no Olimpo por uma existência dividida entre a mais alta esfera do céu e as profundidades mais interiores da Terra.

Shakespeare, Cervantes, Michelângelo, são alguns exemplos dessa melancolia conscientemente cultivada. Pois a síntese mais perfeita para a inteligência se atinge quando o verdadeiro humor se acerca da melancolia, ou quando a verdadeira melancolia se transfigura pela ação do humor.

14. Solipsismo (do latim "solu-, «só» +ipse, «mesmo»+-ismo".) é a concepção filosófica de que, além de nós, só existem as nossas experiências. O solipsismo é a consequência extrema de se acreditar que o conhecimento deve estar fundado em estados de experiência interiores e pessoais, não se conseguindo estabelecer uma relação direta entre esses estados e o conhecimento objetivo de algo para além deles. $O$ "solipsismo do momento presente" estende este ceticismo aos nossos próprios estados passados, de tal modo que tudo o que resta é o eu presente.

15. CORNFORD, F. M. Principium Sapientiae: as origens do pensamento filosófico grego. Trad. Maria Manuela Rocheta dos Santos. 3. ed. Lisboa: Fundação Calouste Gulbenkian, 1989. Resenha de João Mattar

\section{BIBLIOGRAFIA:}

Bloom, Harold: Abaixo as verdades sagradas. Companhia de Bolso, São Paulo,2012.

: The Anatomy of the Influence-

Literature as a Way of Life. Yale University Press, Londres, 2011.

\section{: A Angustia da Influência: uma}

teoria da Poesia. Edições Cotovia, Lisboa, 1991.

Bolzoni, Lina: Il cuore di Cristallo- Ragionamento d'amore, poesia e ritratto nel Rinascimento. Giulio Einaudi Editore, Torino, 2011.

Brook, Peter: 0 espaço vazio. Ed. Orfeu Negro, 2011, Lisboa.

Celant, Germano: Anselm Kiefer- II sale della
Terra. Skira ,2011, Milano.

Cornford. F.M: Principium Sapientiae: As origens do Pensamento Filosófico Grego. Editora Fundação Calouste Gulbenkian, Lisboa, 1989.

Forster, Kurt M., Mazzucco, Katia: Introduzione ad Aby Warburg e all Atlante della Memoria, Bruno Mondadori, Milano, 2002.

Muhana, Adma: Poesia e Pintura ou Pintura e Poesia- Tratado Seiscentista de Manuel Pires de Almeida. FAPESP/EdUSP, São Paulo, 2002.

Oliveira, Maria do Céu Diel: Conversações com imagens in Diálogos com a Arte, Revista de Arte, Cultura e Educação, volume 1, 2010, pags 9 a 22, Braga.

Pepiatt, Michael: Em El taller de Giacometti, 2010, Barcelona.

Vircondelet, Alan: Balthus - Memorias . Editorial Lumen S.A, Barcelona 2002.

Yates, Frances A: The Theatre of the World. Barnes and Noble, New York, 2009.

\section{FILMOGRAFIA:}

Over your cities Grass Will grow- Sophie FiennesGermany, 2010.

\section{SOBRE A AUTORA}

Maria do Céu Diel de Oliveira. Professora Associada do Departamento de Desenho da Escola de Belas Artes. Doutora em Educação pela Universidade Estadual de Campinas (2000).

E-mail: mariadiel@gmail.com 


\section{UM OLHAR SOBRE A POÉTICA DOS PARANGOLÉS DE HÉLIO OITICICA}

\section{Amanda Gatinho Teixeira PPGA-UFPA}

\section{Resumo}

O presente texto aborda a poética de Hélio Oiticica mediante os Parangolés, sua obra emblemática, em que o espectador tornando-se participador, podia vestir a cor, dançar, movimentar-se e ter a experiência da cor em seu próprio corpo. Assim como, analisar como se dá a fusão do criadorparticipador nos Parangolés, por meio do conceito de Anti-arte; apontar como se deu a apreensão e o uso de elementos do cotidiano; como emprestar uma gíria carioca, para dar nome a sua obra; e como utilizar os elementos construtivos estruturais populares da cultura do morro da Mangueira e do samba, vivência esta que teve conseqüências profundas no seu trabalho. Tanto que quase um ano e meio depois de seu primeiro contato, já estava levando os mangueirenses ao MAM-RJ, ato que contribuiu para o processo de dessacralização da obra de arte no Brasil.

\section{Palavras-chave:}

Parangolés, Hélio Oiticica, anti-arte.

\section{INTRODUÇÃO}

Artista de vanguarda, anarquista, polêmico e revolucionário. Esses podem ser alguns dos adjetivos para definir Hélio Oiticica, reconhecido internacionalmente como um dos nomes mais importantes da arte contemporânea. Seus trabalhos foram experimentais ao longo de toda sua vida, além de lutar contra a atitude meramente contemplativa por parte do expectador, ao propor relações sensoriais e corpóreas, gerando uma nova percepção de obra de arte, de acordo com as reflexões fenomenológicas de Merleau-Ponty.

Autor dos emblemáticos Parangolés, conceituado pelo próprio artista de "antiarte por excelência", que consistem basicamente em capas de tecidos

\section{Abstract}

The present text approaches the artistic poetics of Hélio Oiticica through the Parangolés, his emblematic work, in which the spectator becoming participant, could wear the color, dance, move and have the experience of color in his own body. As well as analyzing how the creator-participator merges in the Parangolés, through the concept of Anti-art; To point out how the apprehension and use of elements of daily life occurred; How to lend a carioca slang, to name his work; And how to use the popular structural constructive elements of the Mangueira hill and samba culture, an experience that had profound consequences for their work. So much so that almost a year and a half after his first contact, he was already taking the mangueirenses to MAM-RJ, an act that contributed to the process of desacralization of the work of art in Brazil. For this understanding, qualitative researches were carried out in bibliographies on the subject.

Keywords:

Hélio Oiticica. Parangolés. Anti-arte.

coloridos para vestir, dançar, "incorporar", ou ainda bandeiras, tendas, estandartes coloridos, que fundem elementos como: cor, poesia, fotografia, dança e música, e pressupõem uma manifestação cultural coletiva.

Arti-arte - compreensão e razão de ser do artista não mais como um criador para a contemplação mas como um motivador para a criação - a criação como tal se completa pela participação dinâmica do "espectador", agora considerado "participador". Anti-arte seria uma completação da necessidade coletiva de uma atividade criadora latente, que seria motivada de um determinado modo pelo artista: ficam portanto invalidadas as posições metafísicas, intelectualista e esteticista [...] é pois uma "realização criativa" o que propõe o artista, realização esta isenta de premissas morais, intelectuais ou estéticas - a anti-arte está 
isenta disto - é uma simples posição do homem nele mesmo e nas suas possibilidades criativas vitais. [...] "Parangolé" é a formulação definitiva do que seja a antiarte ambiental, justamente porque nessas obras foi-me dada oportunidade, a idéia, de fundir cor, estruturas, sentido poético, dança, palavra, fotografia - foi o compromisso definitivo com o que defino por totalidade-obra (OITICICA, 1966, p. 1-2). ${ }^{1}$

"Estou possuído", "Incorporo a revolta", "Capa da liberdade", "Da adversidade vivemos", estas são algumas das "mensagens" utilizadas sobre as capas. Nesta obra de Oiticica, o espectador é convidado a vesti-las e a dançar, determinando uma transformação expressivo-corporal. 0 ato de vestir os Parangolés traduz a totalidade vivencial da obra, pois ao desdobrá-la, tendo como núcleo central o seu próprio corpo, o espectador (agora considerado participador) vivência a transmutação espacial, percebendo-se como "núcleo" estrutural da obra.

\section{SIGNIFICADO DA PALAVRA PARANGOLÉ}

Oiticica descobriu essa palavra na rua, ao observar uma espécie de construção engendrada por um mendigo, no qual havia um pedaço de aniagem pregada, que dizia: "aqui é..." e a única coisa que ele entendeu que estava escrito, era a palavra "Parangolé".

Tal palavra é uma expressão idiomática, oriunda da gíria utilizada no Rio de Janeiro, que possui diferentes significados: "agitação súbita", "alegria", "animação", "situações inesperadas entre pessoas". Para o poeta Waly Salomão, autor de uma biografia de Oiticica, conta que na época a pergunta "qual é o parangolé? significaria o que é que há? como vão as coisas?" (REIS, 2006, p.34)

\section{ENTRE AS ESCOLAS DE SAMBA E A BRASILIDADE: O CONTEXTO HISTÓRICO- SOCIAL DE OITICICA.}

Os Parangolés surgiram na década de 60, período em que o Brasil vivia anos de censura e ditadura, mas também de uma crescente efervescência cultural, como o movimento musical conhecido por Tropicália². Esta foi uma das linhas de força entre as quais Oiticica se movimentava, assim como:

[...] a atração crescente que a música dos morros e as escolas de samba passaram a exercer sobre a classe média carioca; as modificações pelas quais as escolas de samba estavam passando, com a cada vez mais decisiva influência de carnavalescos de "classe média"; as ideias sobre cultura popular discutidas no âmbito do Centro Populares de Cultura (CPC) da Une, e do nascente Cinema Novo; as políticas oficiais para as favelas, e a alternativa urbanização/remoção; a descoberta contracultural das drogas e a criação de um novo mercado para o "tráfico de entorpecentes" dos morros cariocas (e também a criação de um novo tipo de "bandidagem"); os embates entre as várias definições de brasilidade e autenticidade em vários campos artísticos do país (incluindo a invenção da Mangueira como no espaço do samba mais autêntico). (VIANNA, 2001, p.3)

Esta vivência com a Mangueira marcou profundamente seu trabalho, tanto que os Parangolés são o primeiro fruto desse contato, gerando experiências ao mesmo tempo individuais e coletivas, mas que revelam a força de superação do individualismo.

\section{O EXPERIMENTALISMO [VIVENCIAL] NA MANGUEIRA}

Em 1964, Oiticica visitou pela primeira vez à favela levado pelo amigo escultor, Jackson Ribeiro que ajudava Amílcar de Castro na confecção de alegorias para o desfile da Escola de Samba Estação Primeira de Mangueira, do carnaval daquele ano. Hélio ficou tão fascinado com o que viu que passou a freqüentar o morro quase que diariamente, fazendo amizades, fumando e aprendendo a dançar samba, tanto que se tornou passista da Escola (Fig.1).

Oiticica começou a incorporar essa experiência com o espaço dionisíaco da Mangueira, o que teve conseqüências profundas, tanto na sua vivência quanto nos conceitos utilizados nos seus trabalhos artísticos. Para Hélio, o potencial encontrado no morro da Mangueira tratou-se da expressão de uma vitalidade criativa e transgressora, por ser capaz de superar estruturas de vida e de representação opressiva e estagnadas. Em carta para Lygia Clark, ele afirmava: "Quando me diziam - não vá a Mangueira. Pensava eu: eu não digo nada e vou, pois adorava" (OITICICA, apud BASUALDO, 2007, p. 17)

Porém, a relação de Oiticica com a favela da Mangueira, não pode ser considerada um fenômeno isolado e nem incomum no meio cultural e intelectual da época. Pois desde o final da década de 50, havia no Brasil um processo de aproximação entre a intelectualidade de esquerda e as camadas 


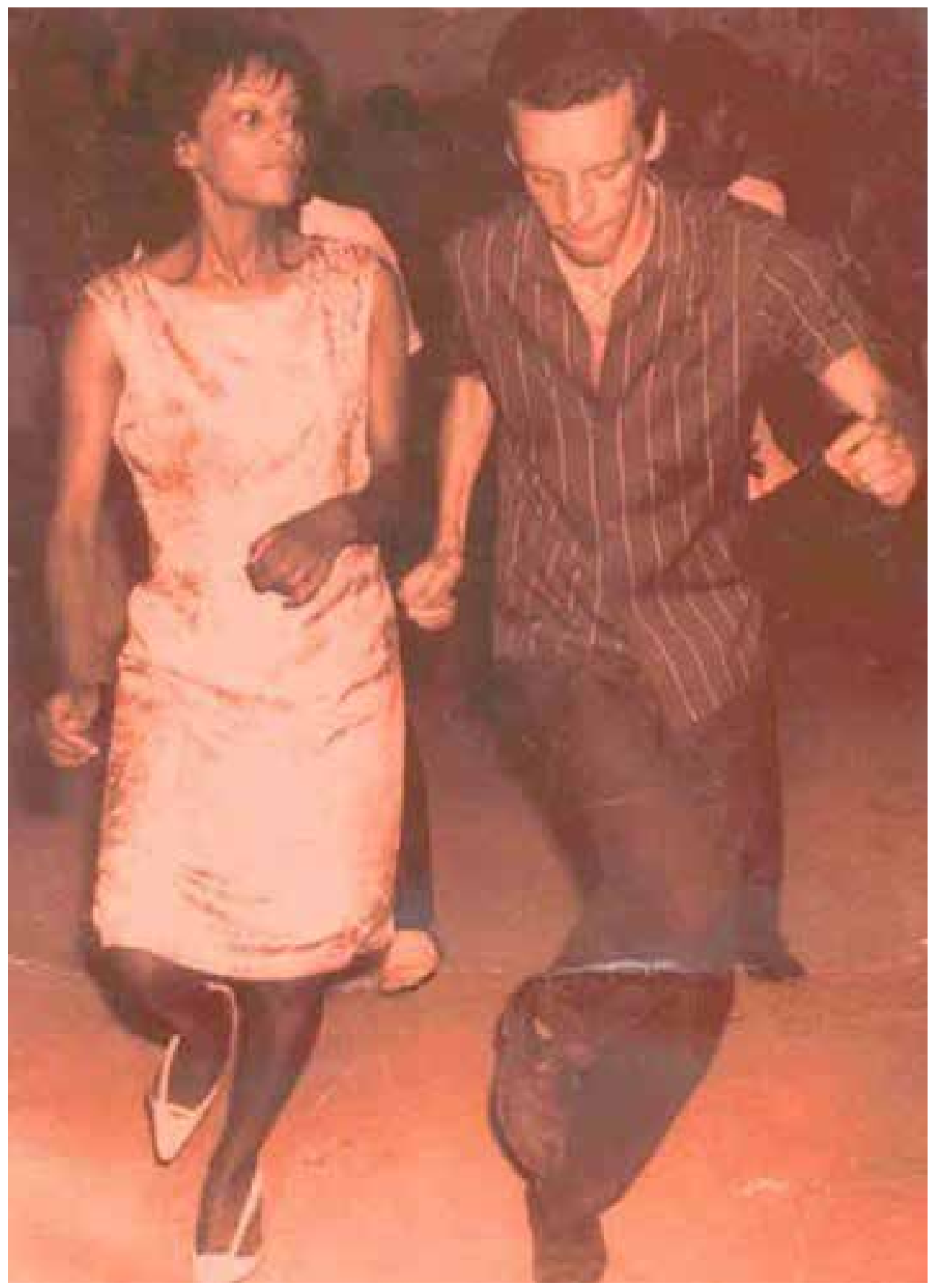

Figura 1 - Hélio Oiticica e Nininha Chochoba, ensaiando na Mangueira, 1965. Disponível em: <http://chacalog.zip.net/images/helionininha.jpg>

pobres da população, devido a contestação política sobre as desigualdades do país.

\section{ATO NO MAM-RJ E A DESSACRALIZAÇÃO DA OBRA DE ARTE}

$\mathrm{Na}$ inauguração da exposição "Opinião 65" no Museu de Arte Moderna do Rio de Janeiro, em agosto de 1965, Oiticica apresentou publicamente pela primeira vez seus Parangolés.

[...] essa mostra representou o momento privilegiado no qual as discussões sobre a volta da figuração tomaram corpo pela primeira vez e de forma variada [...] "Opinião 65" trouxe o posicionamento dos artistas após a instauração do regime militar. A exposição foi, no dizer de muitos críticos (como Frederico Morais, Wilson Coutinho, Mário Pedrosa e Ferreira Gullar), a primeira manifestação efetiva das artes plásticas com relação ao golpe de 1964 . (REIS, 2006, p. 31)

$\mathrm{Na}$ época em que se entrava nos museus com terno e gravata, Oiticica levou uma ala de passistas da favela e da escola de samba da Mangueira para apresentar, em seus corpos os Parangolés (Fig.2). 


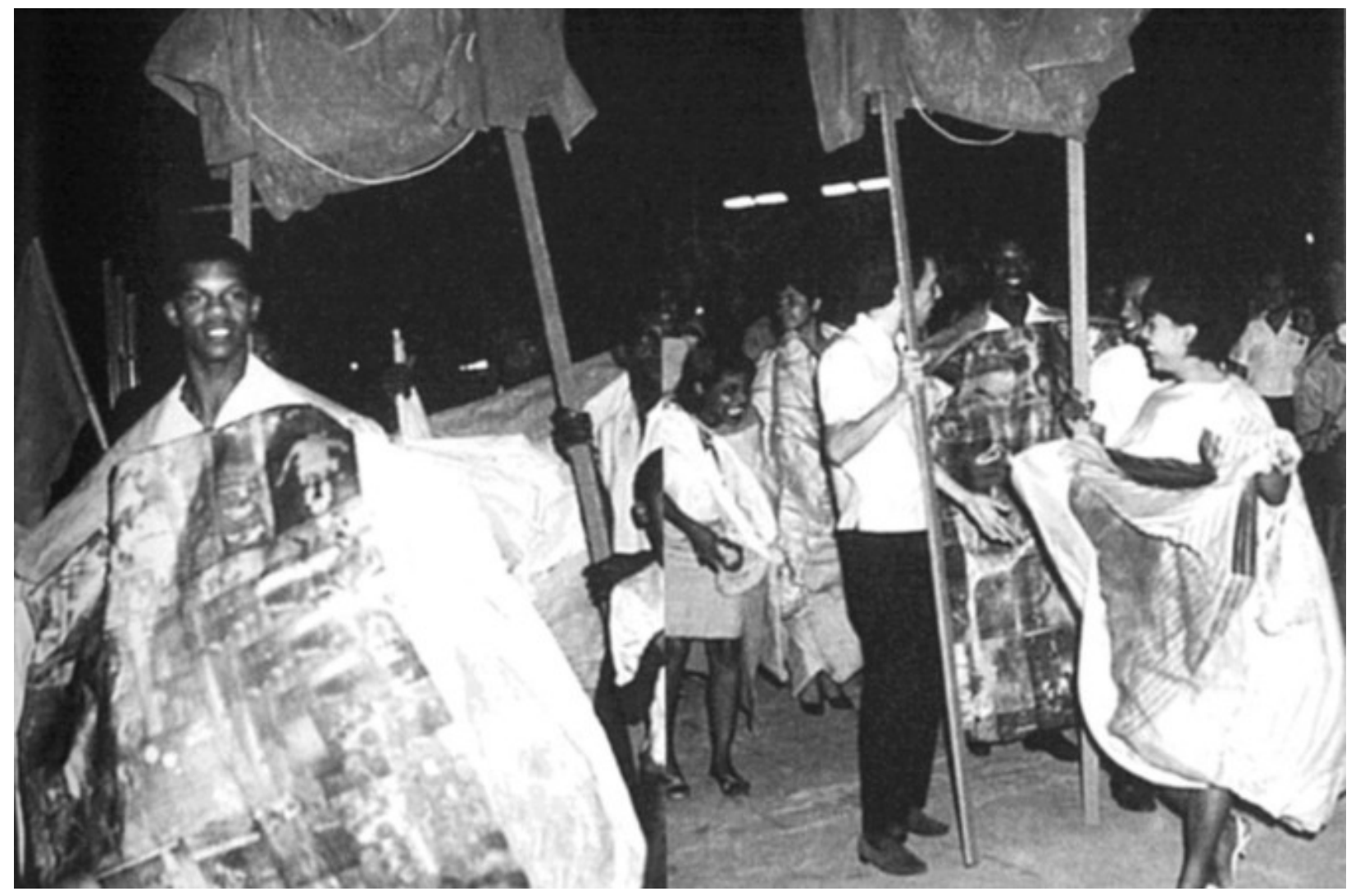

Figura 2 - Hélio Oiticica em manifestação no MAM-Rj. Fonte: SOUZA, [s/d], p.5.

Tal evento resultou em conflito, pois a direção do museu não permitiu a entrada e a exibição dos passistas dentro de suas instalações e a apresentação se deu nos jardins do MAM-RJ. 0 ato foi aplaudido pelos críticos, jornalistas, artistas e parte do público que lotavam as dependências. Os motivos alegados para o veto, apurados por jornais da época foram o barulho dos pandeiros, tamborins e frigideiras.

Este ato foi de grande importância, pois marcou o auge da dessacralização e a real tentativa de democratização da obra de arte, por meio da união da cultura popular com a erudita, firmando assim uma relativização cultural em que o samba conquista o sacrossanto espaço museal e este "desce" à quadra de samba.

\section{OITICICA E O PRINCÍPIO CRIATIVO DA ARQUITETURA FAVELAR}

O mundo das favelas cariocas dos anos 60 já era inteiramente urbano, porém, segregado do reconhecimento social da cidade. Habitado por uma população pobre, ora vistas como portadoras de riqueza folclórica de raízes, ora vistas como incivilizadas, atrasadas e perigosas. E é esse cenário que Hélio frequentava quase que diariamente, observando entre outros elementos, a arquitetura peculiar típica de paisagens urbanas periféricas.

Hélio buscaria nos Parangolés uma estrutura de caráter universal. Até certo ponto que o artista procura e elabora da favela e das manifestações populares (tanto as organizadas, como escolas de samba, frevos, feiras, ranchos, futebol, festas de toda ordem, quanto as espontâneas ou casuais) ou ainda as construções populares como as casas de mendigos; estas são suas estruturas universalizáveis e o que é retirado delas são os princípios de flexibilidade, participação, coletividade, improvisação e de ginga.

Seria, pois o "Parangolé" um buscar, antes de mais nada estrutural básico na constituição do mundo dos objetos, a procura das raízes da gênese objetiva da obra, a plasmação direta perceptiva da mesma. Esse interesse, pois, pela primitividade construtiva popular que soe acontecer nas 


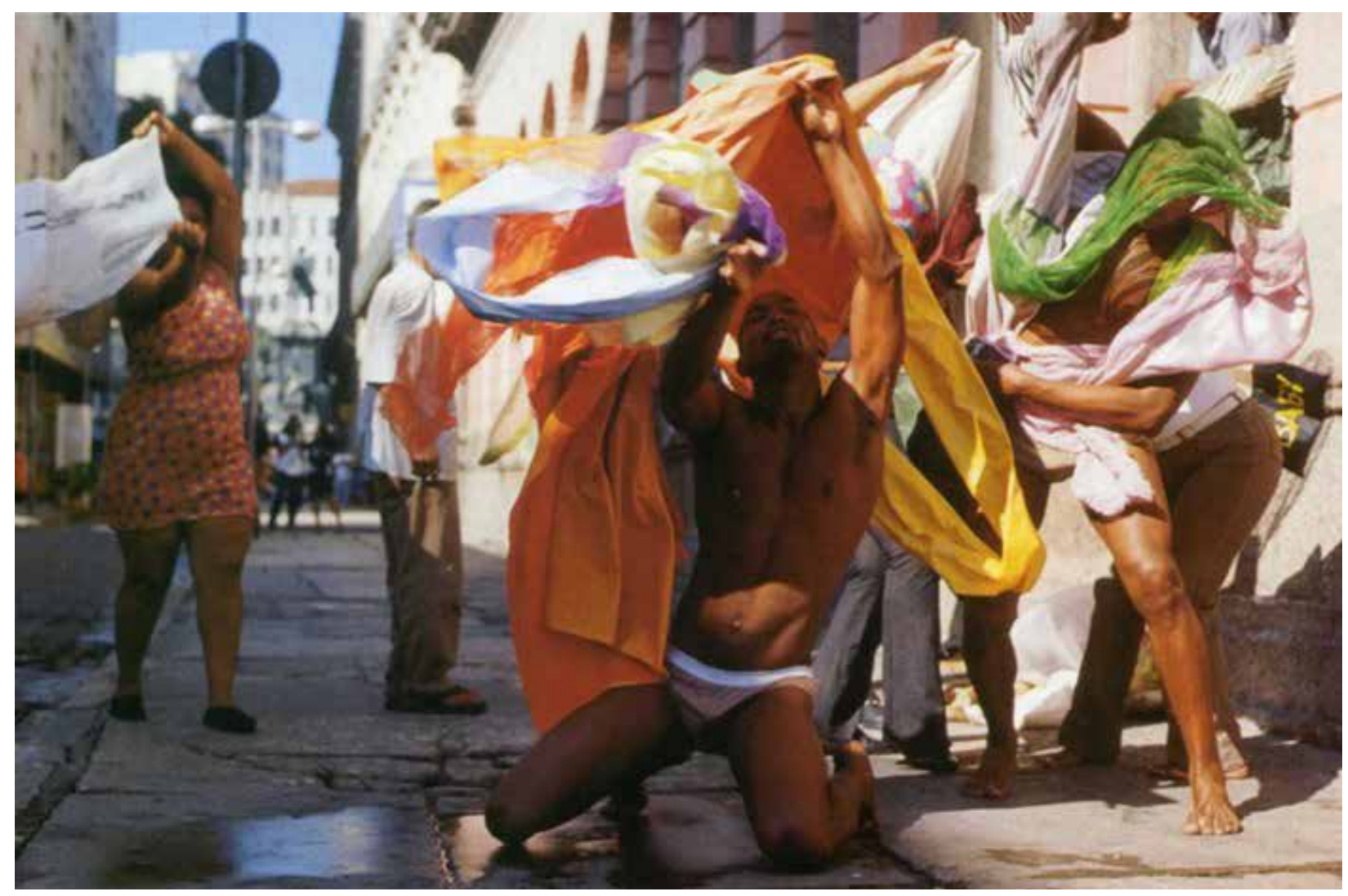

Figura 3 - Performance de populares com os Parangolés. Fonte: Parte integrante do catálogo da exposição "Além do espaço" de Hélio Oiticica.

paisagens urbanas, suburbanas, rurais, etc., obras que revelam um núcleo construtivo primário mas de um sentido espacial definido, uma totalidade (OITICICA, 1964a, p. 2)

A arquitetura orgânica da favela, assim como a dança, baseia-se também no improviso. A forma de um barraco é constantemente alterada, renovada e ampliada. É mais um abrigo que uma habitação, sua configuração é puramente contingencial, pois depende dos restos de materiais de construção disponibilizados, das condições do local, bem como as do construtor e sua família.

De acordo com Oiticica, na arquitetura da favela,

[...] está implícito um caráter do "Parangolé", tal a organicidade estrutural entre os elementos que $\mathrm{o}$ constituem e a circulação interna e o desmembramento externo dessas construções; não há passagens bruscas do "quarto" para a "sala" ou "cozinha", mas o essencial que define cada parte que se liga à outra em continuidade. (ibidem p.4)

Oiticica chegará à negação de posturas rígidas e elitistas, a partir da favela por meio da dança, no dia-a-dia e no espaço lá vivenciados.

\section{A DESCOBERTA DO ATO EXPRESSIVO CORPORAL E A INCORPORAÇÃO DO CORPO NA OBRA E DA OBRA NO CORPO}

O interesse de Oiticica pela dança, pelo ritmo, pelo samba, surgiu através de uma necessidade vital de desintelectualização e da necessidade de uma livre expressão, já que o próprio artista sentia-se ameaçado pela sua excessiva intelectualização.

\begin{abstract}
A dança é por excelência a busca do ato expressivo direto [...] a dança "dionisíaca" que nasce do ritmo interior do coletivo, que se externa como característica de grupos Populares, nações. etc. A improvisação reina aqui no lugar da coreografia organizada; em verdade quanto mais livre a improvisação melhor; há como que uma imersão no ritmo, uma identificação vital completa do gesto, do ato como ritmo, uma fluência onde o intelecto permanece como que obscurecido por uma força mítica interna, individual e coletiva (em verdade não se pode aí estabelecer a separação).
\end{abstract}

[...] A experiência da dança (o samba) deu-me portanto a exata idéia do que seja a criação pelo ato corporal, a contínua transformabilidade - De outro lado, porém, revelou-me o que chamo de 


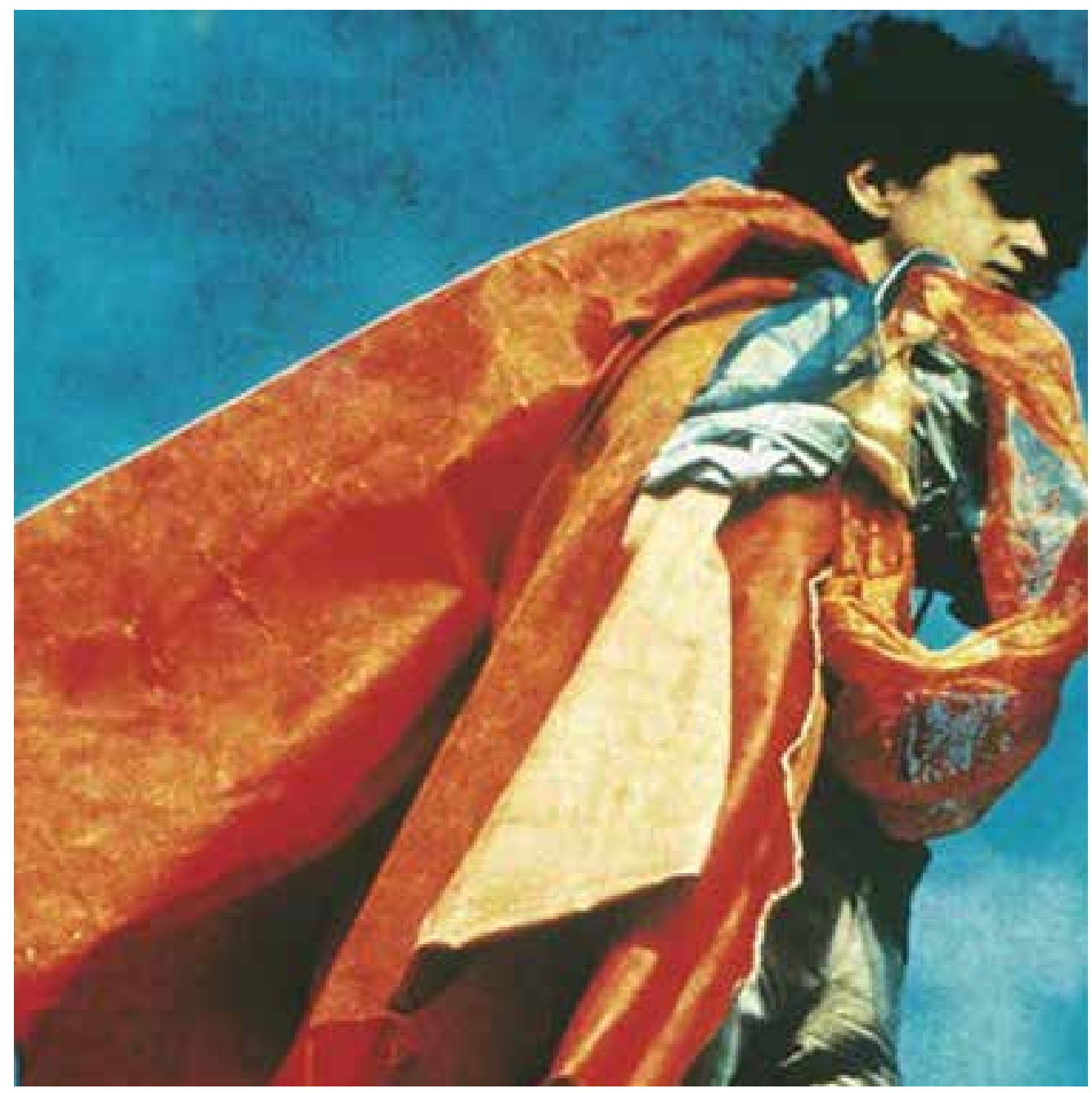

Figura 3 - Caetano Veloso usando P04 Parangolé 01, 1964. Disponível em: <http://3. bp.blogspot.com/_wyOQq3rG2wE/TEPE35mCixl/AAAAAAAAAYI/xw_TCcfBn6U/s1600/ parangole-1+helio.jpg>

"estar" das coisas, ou seja a expressão estática dos objetos, sua imanência expressiva, que é aqui o gosto da imanência do ato corporal expressivo, que se transforma sem cessar. (OITICICA, 1965, p. 1-4)

Os Parangolés necessitam da participação corporal direta, além de revestir o corpo, pede que este se movimente que dance (Fig.3). A dança é elevada a um nível de experimentalidade aberta. Por meio da expressão corporal, os Parangolés manifestam a cor no espaço ambiental através da aeração da cor.

[...] o espectador "veste" a capa, que se constitui de camadas de pano de cor que se revelam à medida em que este se movimenta correndo ou dançando. A obra requer aí a participação corporal direta; além de revestir o corpo, pede que este se movimente, que dance em última análise. O próprio "ato de vestir" a obra já implica numa transmutação expressivocorporal do espectador, característica primordial da dança, sua primeira condição. (OITICICA, 1964b, p. 1)
Para Hélio, a dança, representada pelo samba contribuiu para o ambiente de liberdade, alegria e ineditismo, uma perfeita comunhão da expressão catártica e extática.

[...] As imagens liberadas na dança são móveis, rápidas, inapreensíveis - são o oposto do ícone, estático e característico das artes ditas plásticas - em verdade a dança, o ritmo, são o próprio ato plástico na sua crudeza essencial - está aí apontada a direção da descoberta da imanência. Esse ato, a imersão no ritmo, é um puro ato criador, uma arte - é a criação do próprio ato, da continuidade; é também, como o são todos os atos da expressão criadora, um criador de imagens - aliás, para mim, foi como que uma nova descoberta da imagem, uma recriação da imagem, abarcando, como não poderia de ser, a expressão plástica na minha obra. (OITICICA apud FAVARETTO, 1992, p.115).

O Parangolé requer a participação mais ativa do espectador e não sua mera contemplação 


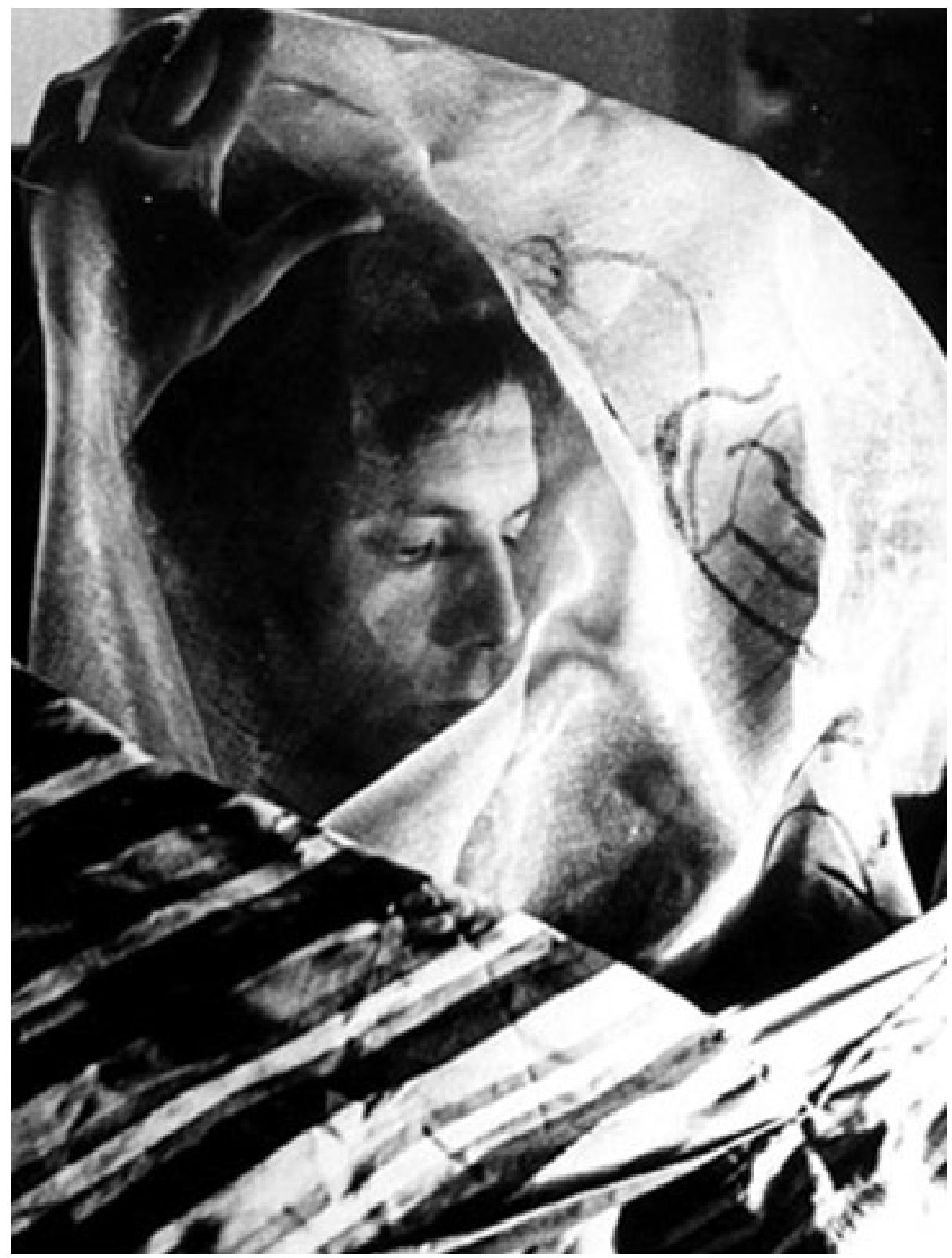

Figura 5 - Hélio Oiticica com o Parangolés P19, Capa 15. Disponível em: <http://jc3. uol.com.br/blogs/repositorio/parangole_oiticica_300_fi(1).jpg>

ou observação (Fig.4). O ato de vestir, andar ou dançar com um Parangolé traz um outro elemento presente a "estrutura-ação". A ação, ao modificar o caráter do espectador que se torna um participante, por meio da experimentação do elemento cor (estrutura-cor) no espaço, seja ela pela dança ou movimento. Assim, Oiticica assume um importante papel na especificidade da participação do espectador na arte brasileira. A participação ativa do espectador, vista como apreensão dos significados da obra, ligava-se para ele à participação corporal (vivencial) e à participação semântica (intelectiva).
Vestir as obras não é simplesmente fazer do corpo um suporte. De acordo com Oiticica, o Parangolé é a incorporação do corpo na obra e da obra no corpo.

Há aqui uma necessidade de "expressão-total", onde espectador e obra não mais se distanciem na praticidade do diálogo, mas que seja esse diálogo aqui procurado pela participação por "atos" desse espectador. O "espectador" passaria a ser então "participador" na obra. As formas fundamentais primeiras do Parangolé são a "tenda", o "estandarte" e a "capa", 3 posições espaciais na relação obraparticipador - $\mathrm{Na}$ "tenda" o participador penetra para desvendar a estrutura-cor espacial da obra; o "estandarte" é a estrutura ligada ao ato de carregar que aí se cumpre pelo participador; a "capa" que cumpre 3 ciclos: o participador assiste a outro que 
a veste, depois ele mesmo a veste e desvenda a estrutura-cor da mesma, e por fim participa de um vestir-assistir coletivo. A "capa" seria a valorização expressiva do inter-espaço do sujeito e da obraespaço inter-corporal.

Essa descoberta do espaço inter-corporal através do "ato de vestir" característico da "capa", isto é: houve aí a inserção do ritmo da dança como elemento intrínseco da "capa" e como integradora ambiental dessas formas do Parangolé. (OITICICA, s/d.)

Assim, nos Parangolés o corpo do espectadorparticipante passa a inserir-se na estrutura, tendo a experiência da cor em seu próprio corpo, atingindo um clímax corporal por meio da dança. A vivência da obra que se dava a nível subjetivo passa a ser "incorporada", uma vez que a relação entre obra e participante se torna orgânica (Fig.5).

\section{CONSIDERAÇÕES FINAIS}

Oiticica marcou seu nome na história da arte brasileira e mundial a partir de diversas contribuições. Equiparando-se a importância de alguns de seus antecessores ao buscar uma identidade nacional. Fato este que não era uma questão historicamente nova, haja vista que alguns pintores do romantismo do século XIX, tematizaram 0 indígena e nossa exuberância tropical de maneira idealizada aos moldes do academicismo europeu. Décadas mais tarde, em 1920, os modernistas paulistanos retomam essa busca, por meio da Antropofagia de Oswald de Andrade. Contudo, a presença desses elementos culturais da tropicalidade de Oiticica, não pode e nem deve ser considerado uma caricatura, de como somos compreendidos e nem tão pouco um elogio ufanista e sim um "estado típico da arte brasileira atual".

Através de sua posição anárquica desvenda a fragilidade de concepções elitistas da arte brasileira, ao mostrar um mecanismo ideológico e superficial; além de ser contra os padrões estéticos do mercado de arte, contra a crítica e com os museus e galerias. Seu trabalho foi marcado pela atuação com um compromisso vanguardista e com o exercício experimental da liberdade. Assim como, suas obras influenciaram decisivamente 0 entendimento da arte brasileira no século $X X$, ao redimensionar conceitos, reestruturar a dimensão dos "significados" das obras, reinventar a condição do espectador com a obra artística, em que a interatividade fosse motor vital para a apreensão dos sentidos. Obras como Bólides, Penetráveis, a ambientação Tropicália, explica esse sentido, assim como, os próprios Parangolés, por meio da organicidade da obra com o participante.

Neto de um importante anarquista, José Oiticica, Hélio descobriu na família a prática da filosofia libertária, o que certamente teve uma influência decisiva em todo o seu trabalho. Assim, o artista, sentiu a necessidade de dar um caráter de protesto em algumas de suas capas, surgindo o Parangolé Social e o Poético.

Com o Parangolé Poético, Oiticica achou essencial a participação de outros artistas, em que ficava reservado para vivências de ordem subjetiva. E a partir dessa concepção, surgiu o Parangolé Social ou de Protesto, em que o artista fazia uso da palavra, não apenas no sentido poético como polêmico discursivo, fazendo homenagens aos nossos mitos populares, aos nossos heróis e principalmente com uma "mensagem" social, política, protesto ou grito de revolta.

Mesmo que os Parangolés estejam intimamente ligados à arquitetura das favelas, do carnaval e a experiência do samba, estes não podem ser considerados mimese dos mesmos e Oiticica temia que fossem assim interpretados e nem tão pouco uma discussão sobre o suporte da obra de arte e sim promover uma ruptura do objeto artístico, questionando a sua fruição.

A complexidade de sua obra reflete a sua trajetória artística cercada de originalidade e genialidade o que fez Oiticica ganhar grande repercussão no cenário internacional, dando maior visibilidade para a produção artística brasileira.

\section{NOTAS}

1. Foi mantida a grafia original de Hélio Oiticica em todas as citações deste artigo.

2. Movimento cultural brasileiro que surgiu sob a influência das correntes artísticas de vanguarda e da cultura pop. Misturou manifestações tradicionais da cultura brasileira a inovações estéticas radicais. O nome do movimento foi dado por Hélio Oiticica, a partir de uma ambientação de 1967 , conhecida pelo mesmo nome. 


\section{REFERÊNCIAS}

BASUALDO, Carlos. (Org.) Tropicália: uma revolução na cultura brasileira (1967-1972). São Paulo: Cosac Naify, 2007.

FAVARETTO, Celso Fernando. A invenção de Hélio Oiticica. São Paulo: Edusp, 1992.

FILHO, Cesar Oiticica (Org.). Catálogo da exposição "Hélio Oiticica: museu é o mundo". Rio de Janeiro: Automática, 2011.

JACQUES, Paola Berenstein. Estética da ginga: a arquitetura das favelas através da obra de Hélio Oiticica. Rio de Janeiro: Casa da palavra/ RIOARTE, 2001.

OITICICA, Hélio. A dança da minha experiência. 1965. Disponível em: <http://www.itaucultural. org.br> :Itimo acesso realizado em 8 de Abril de 2011.

.Anotações sobre o "Parangolé". 1964b. Disponível em: <http://www.itaucultural.org.br> :Itimo acesso realizado em 8 de Abril de 2011.

Bases Fundamentais para uma definição do "Parangolé". 1964 a. Disponível em: <http:// www.itaucultural.org.br $>$ :Itimo acesso realizado em 8 de Abril de 2011.

Depoimento sobre o Parangolé. [S/d.] Disponível em: <http://www.itaucultural.org.br> :Itimo acesso realizado em 8 de Abril de 2011.

.Parangolé Poético e Parangolé Social.

1966 Disponível em: <http://www.itaucultural. org.br $>$ :Itimo acesso realizado em 8 de Abril de 2011.

Posição e programa. 1966. Disponível em: <http://www.itaucultural.org.br> :Itimo acesso realizado em 8 de Abril de 2011.

REIS, Paulo. Arte de vanguarda no Brasil: os anos 60. Rio de Janeiro: Jorge Zahar Ed., 2006.

SOUZA, Maria. Parangolé, política e poética do instante no "estado invenção" de Hélio Oiticica. [s/d]. Disponível em: <http://www.cleabrasil. com.br/Grupos/GRUPO\%205\%20\%20CINZA/ PARANGOL\%C3\%89\%20POL\%C3\%8DTICA\%20 E\%20PO\%C3\%89TICA\%20DO\%2OINSTANTE.pdf> Último acesso realizado em 18 de Maio de 2011.
VIANNA, Hermano. Hélio Oiticica como mediador cultural entre o asfalto e o morro. [ $s / d]$. Disponível em: < http://www.overmundo.com. $\mathrm{br} /$ banco/helio-oiticica-como-mediador-entreasfalto-e-morro> :Itimo acesso realizado em 18 de Maio de 2011.

\section{SOBRE A AUTORA}

Amanda Gatinho Teixeiraé mestra em Antropologia pela Universidade Federal do Pará (PPGA/ UFPA), na linha de pesquisa: Paisagem, Memória e Gênero. Membro do Grupo de pesquisa (Geca/ (NPQ) Grupo de Estudo Culturais na Amazônia. É pós-graduada em Design, Computação Gráfica e Multimídia pelo Instituto de Estudos Superiores da Amazônia (2013). Possui graduação em Artes Visuais com habilitação em Artes Plásticas pela Universidade Federal do Pará (2010). É técnica em Design Industrial pelo Centro Federal Tecnológico do Pará (2007). Possui experiência nas áreas de: Design Gráfico, História da Joalheria, História da Arte e do Design, Patrimônio Cultural, Restauração de Obras de Arte e esteve presente na equipe de restauro em telas da Catedral da Sé em Belém. De 2007 a 2011 realizou trabalhos de mediação cultural em espaços museológicos de Belém. 


\section{A GAMBIARRA E O ALEGÓRICO NO CINEMA CONTEMPORÂNEO BRASILEIRO}

\section{Iomana Rocha \\ FAV-UFPA}

\section{Resumo}

A partir da observação de aspectos estéticos presentes em uma certa produção contemporânea do cinema brasileiro, mais especificamente enfocando a construção imagética desenvolvida pela direção de arte e seus elementos, apontase para uma interessante recorrência da utilização consciente de elementos e recursos "gambiarrísticos" pela direção de arte na construção visual dos mesmos. Para apresentar mais detalhadamente observamos o filme Branco sai, preto fica, apontando para a utilização da gambiarra como um potente discurso estético, alegórico e politico.

\section{Palavras-chave:}

Cinema brasileiro; Gambiarra; Estética; Direção de arte

Este artigo faz parte de uma pesquisa mais ampla que desenvolvo observando aspectos estéticos do cinema brasileiro contemporâneo, focando na forma como a direção de arte é proposta, pensadae estruturada nesse contexto. Nos desdobramentos desta pesquisa algumas questões se apresentam como peculiaridades marcantes: a utilização das paisagens com poder narrativo, a presença e bom aproveitamento do acaso na construção da visualidade do filme, o naturalismo poético das imagens, além do fator aqui destacado, que é a presença da gambiarra como potência estética e narrativa. Neste artigo pretendo lançar um olhar sobre esta 'estética da gambiarra', propondo reflexões acerca da imagem cinematográfica que dela resulta.

\section{Abstract}

From the observation of the aesthetic aspects present in a certain contemporary Brazilian cinema, more specifically focusing on the image construction developed by the art department and its elements, we point to an interesting recurrence of the conscious use of "gambiarristic" elements and resources by the Art direction in the visual construction of them. To present more in detail we observe the film Branco sai, preto fica, pointing to the use of gambiarra as a powerful aesthetic, allegorical and political speech.

Keywords:

Brazilian cinema; Gambiarra; Aesthetics; Art direction

\section{O CINEMA BRASILEIRO CONTEMPORÂNEO}

Apesar da heterogeneidade da produção contemporânea do cinema brasileiro, existe uma parcela desses filmes que se destaca no cenário nacional e internacional. Tratam-se de filmes produzidos por jovens diretores, marcados por certa inventividade, desprendidos de normas ou regras comumente impostas ao fazer cinematográfico, legitimados por uma curadoria interessada na inovação formal e em posturas de criação e produção menos convencionais.

Uma tendência cinematográfica cujo modus operandi e a própria linguagem se reconfiguram e, de certo modo, se reinventam. Uma forma mais flexível de pensar e fazer cinema, despreocupada com os por vezes inócuos rigores de qualidade típicos do cinema mainstream, valorizando a potencialidade poética e discursiva das imagens.

Alguns termos vêm sendo associados a esta produção contemporânea brasileira, como 
"novíssimo cinema brasileiro" e "cinema de garagem". Este primeiro termo (cunhado por uma parcela da critica especializada) e o que ele representa esteticamente tem sido constantemente discutido, criticado e apontado como genérico, por tratar os filmes de forma homogênea, sem observar suas características específicas.

A também contraditória nomenclatura "cinema de garagem", cunhada por Marcelo Ikeda e Delane Lima em livro homônimo lançado em 2010, refere-se a uma nomenclatura escorregadia, tendo recebido algumas criticas, ou sendo por vezes incompreendida, muito pelo fato de tentar agrupar filmes com estéticas, linguagens ou discursos muito divergentes.

Todavia, segundo Lima (2012), o objetivo maior da observação desta produção do "cinema de garagem" seria trazer para estes filmes um olhar atento, e observar o contexto que os fez surgir. Ainda segundo Lima (2012), este termo na verdade apontaria os rumos de um certo cinema, resultado de um contexto "geracional" marcado pelo advento da tecnologia digital, pelo cineclubismo de internet, pela criação de redes ligando artistas em diversos pontos do país.

Por isso, muitas vezes é difícil delimitar com precisão as fronteiras que circunscrevem esse cinema - e nem estamos muito preocupados com isso. Não estamos interessados em inventar conceitos, normas ou rótulos. "Cinema de Garagem" é um rótulo, e os rótulos são problemáticos quando falamos em arte, assim como também o são outros rótulos como "novíssimo cinema brasileiro", "nouvelle vague", "neorrealismo italiano" ou "cinema novo". O que buscamos é que, acima de tudo, este seja um "ponto de partida" para refletir sobre o estado das coisas no cinema brasileiro de hoje. (IKEDA, LIMA. 2012)

"Cinema de garagem" não aponta apenas para um modelo de produção, para o barateamento dos equipamentos de produção, e para as possibilidades estéticas vistas antes como "amadorísticas". Fala também de possibilidades estéticas, éticas e políticas que surgiram a partir dessas novas possibilidades. Uma outra forma de estar no mundo, de se conectar com o mundo a partir do audiovisual.

Independente da nomenclatura utilizada, esses filmes transparecem algo que extrapola os filmes em si, envolvendo o entorno, os processos de produção, os afetos, os fatores estéticos e políticos. Trata-se de fazer filmes que valorizam a experimentação dos processos. E trata-se de um fenômeno descentralizado, que ocorre em diversos estados do Brasil.

Ao se tratar sobre este cinema contemporâneo brasileiro, a questão tecnológica é bastante enfatizada por aqueles que discutem o tema, pois a partir da facilidade do digital toda uma conjuntura de produção cinematográfica se reestruturou.

A tecnologia digital democratizou a forma de fazer cinema. Atualmente, devido às possibilidades do digital, é possível fazer filmes mais urgentes, mostrar os trabalhos com mais facilidade e com menos dinheiro. O digital interferiu tanto nas formas de fazer como nas formas de distribuir o cinema. A idéia de redes, que é algo que remete aos anos 60, é retomado em diversos contextos artísticos contemporâneos, assim como no Brasil, como meio de congregar e difundir a produção independente nacional.

Numa tentativa de dar um norte a este contexto cinematográfico atual Delani Lima (2012) coloca algumas características que estariam presentes nessa produção. Segundo ele, estes conceitos seriam: a dramaturgia mínima, a necessidade de urgência nas idéias dos filmes, os afetos, o hibridismo - tanto de gênero como de estética e um minimalismo. "Trata-se de filmes potentes e livres, que ecoam e reverberam" resume Ikeda (2012).

Observa-se também que, nestes filmes, as imagens não são usadas como mero registro de situações préexistentes, mas como processos que impulsionam e estimulam diferentes formas de representação das imagens, questionando a posição do diretor como produtor exclusivo de sentido.

Observa-se assim certo descentramento do sujeito criador da obra cinematográfica. Segundo Mattos, isso está bem presente nesse contexto cinematográfico contemporâneo brasileiro:

\footnotetext{
O conceito de cinema de autor caiu em desgraça em certa parcela de cineastas e críticos jovens. A idéia é devolver à obra (como se ela existisse "em si") uma primazia que teria sido usurpada pela figura do autor individual. Não há sinais de humildade nessa atitude, mas talvez um misto de atitude blasé, uma certa utopia essencialista e um bocado de gregarismo também. (MATTOS, 2011)
} 
No que diz respeito `a forma de produção cinematográfica, existe uma tendência na qual artistas/diretores se agrupam em coletivos, em parte por partilharem de referências estéticas e ideológicas semelhantes, mas também por ver a possibilidade de ter independência e autonomia em suas criações, realizadas de forma colaborativa e experimental.

O modus operandi desses coletivos mostra-se como resistência às formas mais burocráticas e hierarquizadas de produção. Busca-se assim uma quebra com regras e estruturas hierarquizadas advindas do cinema industrial, marcada comumente por uma produção rígida, com roteiros inflexíveis, equipe hierarquizada, autonomia criativa exclusiva do diretor.

Assim, parte dessa produção contemporânea brasileira se configura como uma resistência através da criação de novas alternativas de produção, mais horizontalizadas, nas quais os participantes da equipe do filme possam interferir criativamente, não apenas em seus departamentos, mas no processo criativo do filme em si.

Uma mescla de filme-ensaio, filme-de-arquivo, "filme colaborativo", ensaio visual, filme-diário, filme-carta. Um pouco de ficção e documentário. Um videoclipe. De um lado, documento; de outro, delírio. Um mapa; uma aposta; um gesto. Um filmede-garagem A começar pelo fato de que os filmes respondem a um desejo mais de expressão que de reconhecimento. Em alguns casos, o propósito de viver "no" cinema supera o de viver "do" cinema, refletindo uma linha de continuidade entre o profissional e o vivencial. (MATTOS, 2012b, p. 95)

Tal produção se dá de forma mais fluida, buscandose algo como uma 'artesanalização' do fazer cinematográfico, uma maior permissibilidade da 'errância' e da naturalidade das imagens. Com isso, observa-se uma maior flexibilidade quanto aos períodos de gravação, os prazos, as metas. Bem como uma maior recorrência do set de 'guerrilha', muito presente nas produções brasileiras do cinema novo e cinema marginal.

Este estilo de produção tem suas marcas no resultado final dos filmes, colaborando com a construção de elementos estéticos inerentes a estas experiências contemporâneas do cinema brasileiro. Existe certa afetividade e emoção que vem desde a etapa de produção, ficando marcado na obra, e passando para o espectador:

O olhar pretensiosamente impreciso é direcionado
pela emoção, pela tensão afetiva, pela coreografia
realizada pelo autor e pelo acontecimento fílmico.
Captar com vivência, com a incorporação da
câmera como extensão do próprio corpo. O autor
presente e imagens com a potencialidade dessa
presença. (LIMA, IKEDA, 2011, p. 22)

Trata-se de uma contra resposta ao cinema mainstream e às imagens artificializadas e artificializantes dos meios de massa, que se dá por meio da valorização da sensorialidade, da participação do espectador, da carga conceitual e da potencialidade das imagens em movimento. Trata-se de "criar imagens que buscam afetar, experimentar linguagens coerentes com o conceito, alterar a percepção do olhar e exigir o envolvimento do expectador" (LIMA, IKEDA, 2011, p. 22).

\section{A GAMBIARRA}

O termo 'gambiarra' é comumente usado para definir qualquer procedimento necessário para a constituição de um artefato ou objeto utilitário improvisado. Neste sentido, o termo gambiarra pode ser entendido como uma forma alternativa de design. A questão da gambiarra envolve temas como o desenho de artefatos, o resgate da função social do design, a problemática do lixo, o contexto das idiossincrasias e das necessidades específicas, bem como a identidade da cultura material brasileira.

A prática da gambiarra envolve sempre uma intervenção alternativa, o que também poderia ser definido como uma reapropriação material: uma maneira de usar ou constituir artefatos, através de uma atitude de diferenciação, improvisação, adaptação, ajuste, transformação ou adequação necessária sobre um recurso material disponível, muitas vezes com o objetivo de solucionar uma necessidade específica. Podemos compreender tal atitude como um raciocínio projetivo imediato, determinado pela circunstância momentânea; ou ainda, como uma espécie de design espontâneo.

Informalmente é comum associar o termo gambiarra 'a ideias como 'adaptação', 'improvisação' ou 'remendo'. Da mesma forma, acepções depreciativas costumam ser atribuídas a 
alguns destes tipos de procedimentos, em muitos casos com total fundamento, associando gambiarra à qualidade de precário, malandro ou tosco.

O termo gambiarra também tem sido remetido à idéia do 'jeitinho brasileiro', numa visão que busca enfatizar uma propensão ao espírito criativo, à capacidade inventiva e inovadora, à inteligência e dinâmica da cultura popular; levando em consideração a conjuntura de adversidades às quais muitos estão expostos.

A grosso modo, o 'jeitinho' é sempre uma solução criativa para alguma emergência, seja sob a forma de burlar alguma regra preestabelecida, seja sob a forma de esperteza ou habilidade. Para resolver é necessário uma maneira especial, isto é, eficiente e rápida para tratar do "problema". Não serve qualquer estratégia. A que for adotada tem que produzir os resultados desejados a curtíssimo prazo, não importa se a solução encontrada for definitiva ou não, ideal ou provisória, legal ou ilegal. (BARBOSA, 1992, p. 33)

Podemos ainda associar essas definições de gambiarra aos conceitos de bricolagem. Bricoleur é alguém que trabalha com as mãos e usa meios indiretos, se comparados aos do artesão. 0 bricoleur é adepto de realizar um grande número de tarefas, mas ele não subordina cada uma delas à disponibilidade de matéria-prima e instrumentos concebidos e procurados para o propósito do projeto. Seu universo de instrumentos está próximo, e as regras do seu jogo são sempre fazer, com qualquer coisa que ele tenha à mão" (LÉVISTRAUSS, 1966 p. 38)

Essa proposição levou David Snow (apud SANTOS, 2003) a sugerir o uso metafórico do termo bricoleur para designar qualquer indivíduo que inventa soluções não convencionais, mas pragmáticas, para problemas urgentes.

O conceito de gambiarra e sua poetização vem adentrando o contexto artístico brasileiro há algum tempo, se tornando cada vez mais evidente, como pode ser visto na presença de obras artísticas recentes que se utilizam do que seria esta "estética da Gambiarra".

Dentre algumas, podemos citar a exposição "A Poesia da Gambiarra" com trabalhos do artista
Emmanuel Nassar, apresentada no Centro Cultural Banco do Brasil - Rio de Janeiro em 2003 e no Instituto Tomie Othake - São Paulo em 2004. Destaca-se também a exposição da série "Gambiarra" com fotografias de Cão Guimarães, apresentadas no inSite em San Diego, Estados Unidos, e no Arco - Feira Internacional de Arte Contemporânea de Madrid; além da exposição "Gambiarra - The New Art from Brazil" apresentada no Firstsite Gallery em Colchester, Inglaterra.

Seguindo este caminho estético, é possível observar nas obras de alguns artistas visuais brasileiros essa poética da gambiarra em diversos momentos da história recente. Destaca-se, por exemplo, Arthur Bispo do Rosário, cujos trabalhos diversificam-se entre justaposições de objetos e bordados. Nas justaposições ou bricolagens, ele utiliza geralmente utensílios do cotidiano do hospital psiquiátrico onde morava, como canecas de alumínio, botões, colheres, madeira de caixas de fruta, garrafas de plástico, calçados; e materiais comprados por ele ou pessoas amigas.

Para os bordados, Bispo usa os tecidos disponíveis no hospital, como lençóis ou roupas. Consegue os fios desfiando o uniforme azul de internos. Ele faz também estandartes, fardões, fichários, entre outros, nos quais borda desenhos, nomes de pessoas e lugares, frases relacionadas a notícias de jornal ou episódios bíblicos, reunindo-os em uma espécie de cartografia.

Outro artista brasileiro que imerge no conceito de gambiarra é Helio Oiticica. Podemos dizer que seus Parangolés - pelo fato de abranger toda uma rede de subsistência a partir de uma economia informal, com soluções de baixo custo e de puro improviso - estariam também ligadas a esta estética. Segundo afirmava Oiticica: "Da adversidade vivemos!"(OITICICA apud LAGNADO, 2003), e para ele "adversidade" não significa apenas 'pouquidão', mas também 'oposição': “Tem-se que ser contra, visceralmente contra tudo que seria em suma o conformismo cultural, político, ético, social" (OITICICA apud LAGNADO, 2003).

Outro exemplo do uso do conceito de gambiarra é o já citado trabalho de Cão Guimarães em sua série intitulada "Gambiarra", na qual ele fotografou 
durante anos diversos exemplos de gambiarras que ele encontrou em suas viagens pelo Brasil. Segundo Cão Guimarães (2009): "A gambiarra é justamente a falta de bula e de manuais de instrução, de mapas e de guias. A gambiarra é o não oficioso, o que não foi carimbado pela história e pelo selo de qualidade registrada". Na vivência deste trabalho ele desenvolve o que seria um conceito próprio de gambiarra:

\begin{abstract}
O meu conceito de gambiarra é algo em constante ampliação e mutação. Ele deixa de ser apenas um objeto ou engenhoca perceptível na realidade e se amplia em outras formas e manifestações como gestos, ações, costumes, pensamentos, culminando na própria idéia de existência. A existência enquanto uma grande gambiarra, onde não cabe a bula, o manual de instrução, o mapa ou o guia. A gambiarra enquanto 'phania' ou expressão, uma manifestação do estar no mundo. (GUIMARAES, 2009)
\end{abstract}

Podemos observar nessa produção artística brasileira que a gambiarra, tomado como conceito, envolve transgressão, fraude, sem jamais abdicar de uma ordem, embora muito simples. A gambiarra, mesmo que utilizada com diferentes nuances, com mais ou menos alegoria, é a peça em torno da qual um tipo de discurso está ganhando velocidade. Antes de mais nada, é importante enfatizar que o mecanismo da gambiarra tem um acento político além do estético.

\section{A GAMBIARRA NO CINEMA INDEPENDENTE BRASILEIRO E SEU USO ALEGÓRICO}

O conceito de Gambiarra, como visto, associase diretamente a idéia de se reinventar para sobreviver. Tomando por referência o histórico do cinema brasileiro, podemos associar esta ideia da gambiarra ao contexto dos orçamentos baixos, equipes reduzidas, problemas de distribuição, monopólios das empresas produtoras, escassez de políticas públicas culturais e as consequentes manobras realizadas pelos produtores e equipe técnica destes filmes para se adaptar ao que está posto.

Apesar de, em um conceito amplo, a gambiarra permear todos os departamentos da produção audiovisual não comercial (adaptação de materiais, burlar regras, dar usos diversos a equipamentos, reutilizar materiais, etc), aponta-se aqui a potência da gambiarra mais especificamente no que diz respeito a aspectos plásticos de sua visualidade, evidenciando sua utilização alegórica na produção da imagem.

Os recursos 'gambiarrísticos' vem se mostrando como alternativas interessantes para o diretor e o departamento de arte transpor ideias de forma poética, criativa e funcional, num contexto de parcos orçamentos, equipe reduzida, tempo apertado. Se configurando ainda como uma forma consciente de evidenciar uma estética do artificio.

Historicamente recursos visuais já foram utilizados de forma alegórica no cinema brasileiro. A alegoria e a invenção estão fartamente presentes em filmes do cinema novo e do cinema marginal, com destaque para as obras de Glauber Rocha. No contexto contemporâneo, observamos em algumas produções a utilização da alegoria por meio da gambiarra, que é assumida esteticamente e politicamente, em todas as suas 'falhas' e 'imperfeições'.

Assim como ocorre no contexto das artes visuais, observamos no cinema contemporâneo brasileiro uma evidência do uso conceitual da gambiarra como recurso imagético, propondo com isso uma estética que convida o espectador a participar da construção do universo fílmico, apresentando as alegorias como um recorte crível da realidade paralela do filme.

Diante disso, analisando aspectos que seriam próprios da direção de arte, como objetos, materiais, cenários, busca-se observar como se dá a utilização inventiva e poética de elementos visuais simples, naturalistas, provenientes da gambiarra, mas com forte poder simbólico.

Filmes como 'Esse amor que nos consome' (Alan Ribeiro, 2012), Batguano (Tavinho Teixeira, 2014), Branco sai, preto fica (Adirley Queirós, 2014), A seita (André Antonio, 2015), Brasil S.A. (Marcelo Pedroso, 2014), Animal Político (Tião, 2016), utilizam-se direta ou indiretamente do recurso da gambiarra para produzir seus universos ficcionais. Para apontar essa utilização alegórica de forma mais detalhada, utilizaremos aqui o exemplo do filme "Branco Sai, preto fica".

A linha narrativa deste filme inicia-se em tom documental, tendo como ponto de partida um episódio real ocorrido em um baile de black music 
na Ceilândia, periferia de Brasília, em 1986. Neste dia a polícia invadiu o baile com tiros, rendeu pessoas e deixou, entre os feridos, um homem com uma perna amputada, outro paralisado da cintura para baixo. Ninguém nunca foi responsabilizado.

Aos poucos o filme vai imergindo em uma trama de ficção cientifica distópica, na qual um detetive vem do futuro com o objetivo de investigar o fato ocorrido neste baile e determinar o culpado. Paralelamente, observamos a vida de dois personagens (as vitimas reais do ocorrido, interpretando seus próprios personagens).

Um deles trabalha com readaptação de pernas e pés mecânicos que encontra no lixo ou em ferro velho, vivendo em uma relação biônica e melancólica com seu entorno. 0 outro personagem é um cadeirante que possui uma casa adaptada para sua locomoção com uma interessante tecnologia artesanal, e que passa parte do filme construindo uma 'bomba cultural' para ser usada em um atentado na cidade de Brasília.

Em meio a uma estranha bricolagem de fios e aparelhos rudimentares, passado, presente e futuro se misturam em uma narrativa que apresenta uma Brasília distópica, que exige dos habitantes da Ceilândia, local onde moram os personagens, um passaporte de entrada. Devido a esta e outras questões opressoras, os personagens costuram gradativamente uma punição `a Brasília, planejam um atentado.

A Brasília dos ricos, nunca aparece, já a Ceilândia é cenário e personagem do filme. Trata-se de um bairro real da cidade de Brasília, que trás originalmente a marca dessa gambiarra inerente ao contexto sociocultural brasileiro (seu nome vem da sigla CEI - Campanha de Erradicação de Invasões), é uma cidade artificial, criada para alojar famílias de operários que construíram Brasília e que, sem moradia, tinham ocupado áreas da capital.

Essa relação distópica de uma dominação fascista por parte de Brasília, esse pedido de passaporte, essa segregação, são elementos que tornam a própria Ceilândia uma representação geográfica alegórica no filme. Uma alegoria que se estende não apenas ao contexto de Brasília, mas à diversas outras cidades brasileiras que teimam em empurrar e manter em suas periferias a população negra e pobre.
Ardiley Queiroz constrói um universo e, a partir dele, olha para o mundo real. Os cenários e engenhocas improvisadas pelos personagens não apenas carregam consigo um peso simbólico de afirmação do imaginário popular e seu poder criativo de ressignificação, evidenciando seu potencial estético-político, como também, configura a alegoria de um país-gambiarra.

Trata-se de um filme pertencente a esta produção do cinema contemporâneo brasileiro que vem se destacando por sua linguagem inovadora, na qual é visível uma tendência da exploração do acaso e de elementos naturalistas, com uma produção que se dá de forma mais fluida, reconfigurando o tradicional modus operandi do cinema.

É possível notar neste filme a citada 'artesanalização' do fazer cinematográfico, bem como repercutindo diretamente na concepção da direção de arte. "Branco sai, preto fica" utiliza sua própria escassez de recursos como elemento de invenção e criação.

O filme constrói um universo de artifícios envolvendo os corpos e os espaços por meio da utilização de elementos visuais provenientes do cotidiano, materiais comuns, lixo, ferro velho, pedaços de metal, fios, próteses, maquinas, trens, carros, luzes frias. Enfatizando a utilização de uma 'pobreza tecnológica' como recurso estético altamente expressivo e alegórico.

Em "Branco sai, preto fica", elementos que fazem parte do imaginário popular futurista, como superfícies metalizadas, luzes, máquinas, viagens intergalácticas, naves espaciais, são utilizadas como base para a criação do universo ficcional deste filme. Materiais comuns como folhas de zinco, fios, luz incandescente, são utilizadas de forma a contextualizar, por intermédio do design vernacular próprio da gambiarra, esse universo peculiar e alegórico.

Tal ode ao artificio e a gambiarra é bem representada neste filme quando vemos, por exemplo, um contêiner comum ser representado como uma nave de um viajante do tempo. O discurso do personagem viajante, em meio ao movimento de luzes coloridas de boate que acendem no interior deste container, dá o estranhamento necessário para que aquele elemento se reconfigure em seu significado e passe a ser visto pelo espectador como uma nave de fato. 
Este mesmo recurso é aplicado na sala subterrânea do personagem cadeirante, cenografada com elementos metálicos e luzes frias, mantendo a ideia de um ambiente futurista notadamente marcado pela carga de subalternidade que a gambiarra carrega consigo. Nesta sala, uma peça de metal interligada por fios é 'preenchida' por um material cultural duvidoso, com objetivo de fazer uma bomba que será lançada sobre a cidade de Brasília.

Esse recurso estético utilizado por Ardiley mantém um jogo de signos onde o espectador precisa compactuar da estética para embarcar na proposta das alegorias, vendo o que está posto como algo crível e potente. A partir do momento em que este jogo é aceito, a estética da gambiarra presente nestes cenários e objetos ganha uma potência visual e discursiva que impressiona.

Acredita-se que estes recursos imagéticos apresentados, presentes também em outros filmes da produção contemporânea brasileira, colaboraram na experimentação de linguagens e na criação de imagens poéticas e alegóricas, que afetam e questionam. Além de colaborar para o entendimento de uma estética inventiva, a presença alegórica das gambiarras na construção imagética do filme aponta para uma forte intenção critica do diretor, bem como a afirmação deste filme como manifesto estético e politico.

\section{NOTA}

1. Enfatiza-se que os autores não associam essa produção com algo geracional no que diz respeito à idade, pois segundo afirma Lima (2012), existem realizadores de todas as idades ligadas a este cinema contemporâneo de que trata o termo. "É mais uma questão de coragem que de idade" completa Delani Lima.

\section{BIBLIOGRAFIA}

AUMONT, Jacques. A Estética do filme. São Paulo, Campinas, São Paulo: Editora Papirus, 1995.

BARBOSA, Livia. O Jeitinho Brasileiro. Rio de Janeiro: Editora Campus, 1992

BAUDRILLARD, Jean. 0 sistema dos objetos. São Paulo: Editora Perspectiva, 1973.
BOUFLER, Rodrigo Naumann. A Questão da Gambiarra: formas alternativas de desenvolver artefatos e suas relações com 0 design de produtos. FAU-USP: São Paulo, 2006.

GUIMARÃES, CAO. Entrevista "Gambiarras". San Juan, II Trienal Poligráfica de San Juan, 01/2009. Entrevista a Carla Zaccagnini. Disponivel em: <http://www.caoguimaraes.com/ wordpress/wp-content/uploads/2012/12/ gambiarras-ii-trienal-poligrafica-de-san-juan. pdf $>$ Acesso em 10/11/15.

HAMBURGER, Vera. Arte em cena: A direção de arte no cinema brasileiro. São Paulo: Edições SESC, 2014.

LAGNADO, Lisette. O Malabarista e a Gambiarra. Revista Digital Trópico. Publicado em 03/10/2003. Disponível em <http://pphp. uol.com.br/tropico/html/textos/1693,1.shl> Acesso em 05/10/15.

LÉVI-STRAUSS, Claude. 0 Pensamento Selvagem. São Paulo: Companhia Editora Nacional, 1970.

LIMA, Dellani, IKEDA, Marcelo. Cinema de garagem: Um inventario afetivo sobre o jovem cinema brasileiro do século XXI. Belo Horizonte: SuburbanaCo, 2011.

(orgs). Cinema

de Garagem: Panorama da produção brasileira independente do novo século. Rio de Janeiro: WSET Multimídia, 2012a. Disponível em: <http:// www.cinemadegaragem.com/2012/download/ catalogo-cinemadegaragem.pdf $>$ Acesso em: 05/03/2012.

\section{Debate 1 -}

"Cinema de Garagem": um "inventário afetivo do jovem cinema contemporâneo brasileiro do século XXI.: [2012b]. Debate realizado na Mostra Cinema de Garagem - Caixa Cultural - RJ. Disponível em: http://www.cine madegaragem. com/2012/download/D1. mp3. Acesso em 10/03/2014.

MATTOS. C. Alberto. Novíssimos e gregários. Janeiro de 2011. Disponível em: http://carmattos. com/2011/01/31/novissimos-e-gregarios/. Acesso em 27/10/2012. 
In: LIMA, Dellani, IKEDA, Marcelo. (orgs). Catálogo Cinema de Garagem: Panorama da produção brasileira independente do novo século. Rio de Janeiro: WSET Multimídia, 2012b. Disponível em: <http://www.cinemadegaragem.com/2012/ download/catalogo-cinemadegaragem.pdf.> Acesso em 05/03/2013.

SANTOS, Maria Cecília Loschiavo dos. As Cidades de Plástico e Papelão. Tese de Livredocência, São Paulo, FAU-USP, 2003

\section{SOBRE A AUTORA}

Iomana Rocha é professora do Curso de Cinema e Audiovisual da Universidade Federal do Pará- UFPA, Doutora em Comunicação pelo PPGCOM - UFPE. 


\title{
SAMBA E BALÉ CLÁSSICO NA CONSTRUÇÃO COREOGRÁFICA DE UMA PORTA-BANDEIRA: APROXIMAÇÕES COM A DANÇA IMANENTE
}

\author{
Ana Flávia Mendes \\ PPGARTES-UFPA
}

\section{Resumo}

Este texto é um relato reflexivo acerca de uma experiência artística vivida pela autora como portabandeira do Auto do Círio, cortejo cênico realizado anualmente em Belém do Pará em homenagem à Nossa Senhora de Nazaré, padroeira dos paraenses. A abordagem parte dos pressupostos da dança imanente (MENDES, 2010) para pensar sobre um processo de criação coreográfica que transita entre o samba e o balé clássico, tidos como matrizes (BIÃO, 2009) e motrizes (LIGIÉRO, 2011) da dança. A argumentação explana os agenciamentos do corpo que dança no processo criativo de uma artista-professora-pesquisa e porta-bandeira e aponta possibilidades metodológicas para o ensino e criação em dança a partir das negociações entre a dança imanente e as danças de escola de samba.

\section{Palavras-chave:}

Dança imanente; Porta-bandeira; Construção coreográfica.

\section{ARTISTA-PROFESSORA-PESQUISADORA... E PORTA-BANDEIRA}

Ser porta-bandeira é um sonho cultivado por muitas garotas nascidas no meio do samba, especialmente aquelas inseridas nas escolas de samba. Não nasci nem me criei no samba, mas durante meu trajeto artístico adotei o universo das escolas de samba como um dos meus contextos de atuação como coreógrafa. Mas, o que uma coreógrafa do campo das poéticas contemporâneas em dança faz no samba?

Quemmeconhece sabe que eu sou uma pesquisadora praticante que fala de um lugar de quem produz dança. Sou uma artista da dança. Minha atuação no mundo do samba é decorrente disto, além de ser fruto de um processo de adoção. Ainda que meus pais tivessem apreço pelas escolas de samba

\section{Abstract}

This text is a reflective account of an artistic experience lived by the author as flag bearer of the Auto do Círio, a scenic procession held annually in Belém do Pará in honor of Nossa Senhora de Nazaré, patroness of Pará's population. The approach is based on the assumptions of immanent dance (MENDES, 2010) to think about a process of choreographic creation that transits between samba and classical ballet, considered as matrices (BIÃO, 2009) and driving (LIGIÉRO, 2011). The argument explains the assemblages of the body that dances in the creative process of an artistteacher-research and flag-bearer and points out methodological possibilities for teaching and creating in dance from the negotiations between immanent dance and samba school dances.

Keywords:

Immanent dance; Flag-bearer; Choreographic creation.

e participassem dos desfiles carnavalescos de Belém como brincantes, nunca foram efetivamente comprometidos com o samba e o carnaval. Deste modo, mais do que uma descendente legítima de sambistas, sou alguém que buscou as escolas de samba por vontade própria.

“Eu nunca morei no morro, não/ Mas tenho o samba que mora em mim", diz a canção de Dimi Kireef para a trilha sonora do filme O samba que mora em mim, de Georgia Guerra-Peixe. Fui criada em uma região de fronteira, entre um bairro considerado nobre e outro, de periferia (Batista Campos e Jurunas, respectivamente), em Belém do Pará. Falo de uma cultura situada entre o centro e a periferia e, como pesquisadora, entre a teoria e a prática, entre o saber e o fazer, entre o empirismo e o cientificismo. Estar entre não é estar no meio de um confronto, mas num lugar de 
agenciamentos entre opostos complementares. Um lugar de potência criadora.

Sou, portanto, um corpo mediador entre centros e periferias, considerando aí toda a dimensão poética destas palavras. É deste lugar que eu venho. É deste lugar que me faço pesquisadora e pesquisa. É deste lugar que vou ao encontro do universo das escolas de samba.

Em minha trajetória carnavalesca, integrei comissões de frente nos desfiles de Belém, coreografei alas e carros alegóricos e, principalmente, fui espectadora, desde a infância, dos desfiles das escolas de samba do grupo especial do Rio de Janeiro.

Essas experiências levaram-me a cultivar grande respeito e admiração por tudo que diz respeito a uma escola de samba e, de modo especial, pelo casal de mestre-sala e porta-bandeira, os responsáveis por conduzir o símbolo maior de uma agremiação carnavalesca, isto é, seu pavilhão.

Lembro-me das brincadeiras de infância em que eu costumava realizar encenações para os membros da família. Dentre as que permanecem mais vivas em minha memória destaca-se a dança do mestre-sala e da porta-bandeira. Eu e meu irmão, com o auxílio de um cabo de vassoura e um pedaço de pano amarrado em sua ponta, fazendo referência à bandeira, costumávamos imitar os casais que apreciávamos na televisão. Talvez, quando criança, eu tenha sonhado em ser uma porta-bandeira, embora não fizesse parte, efetivamente, de uma escola de samba.

Nunca levei a brincadeira a sério, porém, como o mundo dá muitas voltas, girei, girei e fui "bailar" como docente no Programa de Pós-graduação em Artes da Universidade Federal do Pará, em que tive a felicidade de orientar dois importantes trabalhos no âmbito das danças de escola de samba em Belém. Um sobre a dança do portaestandarte, defendido em 2013 por Feliciano Marques, e outro sobre a dança do mestre-sala e da porta-bandeira, de autoria de Arianne Pimentel, defendido em 2014.

Mais ou menos no mesmo período, firmei parceria com Miguel Santa Brígida, artista-professorpesquisador tido como referencial no campo dos estudos sobre escolas de samba. A partir desta parceria, atuei como colaboradora no projeto de extensão Academia Paraense de Mestre-sala, Porta-bandeira e Porta-estandarte e aproximeime da carnavalesca, professora e pesquisadora Cláudia Palheta, cuja pesquisa de mestrado, também defendida pelo PPGARTES, tive o privilégio de avaliar como membro da banca.

No ano de 2013, ao ingressar no pós-doutorado, realizado no Programa de Pós-graduação em Artes Cênicas da Universidade Federal do Estado do Rio de Janeiro (UNIRIO), dediquei parte de minhas reflexões a experiências com a dança do mestre-sala e da porta-bandeira, vividas por mim junto à Escola de Mestre-sala, Porta-bandeira e Porta-estandarte do Rio de Janeiro, fundada por Manoel Dionísio, mestre da cultura popular formador de casais atuantes no carnaval carioca.

Além dessas experiências, coordenei, em 2014, o projeto de pesquisa Majestades do Samba e, mais recentemente, em 2015 e 2016, atuei como porta-bandeira do Auto do Círio, espetáculocortejo em homenagem à Nossa Senhora de Nazaré, padroeira dos paraenses, realizado anualmente em Belém como projeto de extensão da Universidade Federal do Pará.

Como se vê, os estudos em dança no âmbito acadêmico fizeram com que o carnaval atravessasse definitivamente a passarela do meu coração, conquistando espaço não somente como objeto de estudo, mas como práxis determinante para a compreensão do meu ser dançante. Assim, tenho dedicado parte de minha rotina à pesquisa de poéticas e processos de criação em dança, aproximando minha abordagem em dança de meus contextos de atuação artística, entre os quais se situa a dança de mestre-sala e porta-bandeira.

\section{MATRIZES E MOTRIZES DE UMA PORTA-BANDEIRA}

O casal de mestre-sala e porta-bandeira é um par que "formado por um homem e uma mulher, representa um 'casal enamorado' que carrega o principal símbolo da escola - a bandeira" (GONÇALVES, 2010, p. 19). A função da portabandeira, como o próprio nome já diz, é portar - pavilhão da agremiação carnavalesca que representa, enquanto ao mestre-sala cabe proteger este pavilhão, cortejando e zelando por sua parceira de dança. 
A dupla mantém a função dos antigos mestresala e porta-estandarte presentes nos ranchos, blocos e cordões. A dança do par, influenciada originalmente pelos minuetos e contradanças da elite, tornou-se uma espécie de balé popular com códigos e passos característicos (FERREIRA, 2004, p. 369)

Esse balé popular, nomeado por Gonçalves (2010) como "a dança nobre do carnaval", é uma invenção brasileira de matriz africana, criada pelos negros escravos que, em suas celebrações, se "inspiravam" nas danças executadas por seus senhores nos bailes de corte.

Não há como definir precisamente uma razão para a invenção desta dança, mas, particularmente, acredito que seja decorrente de uma mistura de imitação e deboche, tal como os processos de sincretismo religioso, uma vez que prevalecem, entre as contrastantes características plásticas dos movimentos, a leveza e majestade de danças europeias como o minueto e, em contrapartida, os giros e riscos característicos de danças de matriz africana e da capoeira, respectivamente, conforme argumenta Santa Brígida (2012).

É válido relembrar, nesse sentido, o conceito de matrizes estéticas proposto por Bião (2009, p. 33-34), que diz:

no âmbito geral da cultura, assim como no campo mais específico da estética, pode-se sempre buscar compreender um fenômeno contemporâneo a partir do esforço de identificação de sua filiação histórica e de seu parentesco atual com outros fenômenos. A utilização dessa expressão - matrizes estéticas, sempre no plural, possui, do ponto de vista retórico, uma consciente proposição paradoxal, posto que a palavra matriz remete à ideia de mãe, que também remete à ideia de unicidade, quando pensada como uma e única pessoa, do gênero feminino, que alimenta em seu próprio corpo e assim é explicitamente geradora de outra, enquanto a palavra matrizes multiplica esse ente, ainda que se referindo a um mesmo fenômeno - seu descendente direto. O que se pretende, ao recorrer-se a essa figura paradoxal de linguagem, é chamar a atenção para o fato de que na cultura cada fenômeno possui simultaneamente múltiplas matrizes, fruto que é de diversos processos de transculturação. (...) Assim, podemos falar, por exemplo, de matrizes estéticas, a partir de referências linguísticas, religiosas, geográficas, históricas, geo-históricas, étnicas, técnicas, temáticas, teóricas, tecnológicas etc.

Com base nas matrizes desta dança e nas experiências práticas vividas até então, tanto como observadora quanto como dançarina, vivenciei minha estreia como porta-bandeira no Auto do Círio 2015, aos 40 anos de idade. Para tanto, lancei mão de todo o aprendizado que tive na Escola de Mestre-sala, Porta-bandeira e Porta-estandarte do Rio de Janeiro e na Academia Paraense de Mestre-sala, Porta-bandeira e Porta-estandarte, agenciei informações estudadas e compartilhadas com meus orientandos de mestrado, retomei inquietações de meu projeto de pesquisa Majestades do Samba e, ainda, articulei características de dois universos aparentemente distintos, porém complementares, ambos constituintes de minha história de vida: a dança clássica e o samba.

Estudei balé clássico na Escola de Danças Clara Pinto $^{1}$ através do método inglês Royal Academy of Dancing entre os anos de 1994 e 2002. Não cheguei a concluir os chamados graus de formação, mas a experiência que tive foi bastante consistente, ao ponto de até hoje, em alguma medida, eu ainda ser reconhecida como alguém "do balé" entre meus colegas de dança.

Praticar o balé clássico não era uma tarefa muito simples, embora eu a considerasse um desafio bastante prazeroso. 0 auge de minha performance como dançarina clássica deu-se em 1998, quando dancei balés como o lago dos cisnes e 0 quebra nozes. Para tanto foi necessário diminuir vários números na balança. Lembro (com certo saudosismo) dos 58 centímetros de cintura atestados na fita métrica da costureira ao tomar as medidas para a confecção de um figurino. Manter as medidas e o peso em acordo com a proposta técnica e estética do balé clássico era um projeto de vida. Os quadris largos e a coxa grossa herdados dos meus ancestrais, tidos popularmente como preferência nacional dos brasileiros, não cabiam bem naquela dança. Em contrapartida, os braços finos, o pescoço comprido e os seios pouco avantajados garantiam a plasticidade desejada pelas professoras de balé, que diziam: "Da cintura pra cima tu és perfeita!".

E da cintura para baixo? Nada diziam, mas o próprio dançar e a dificuldade com o en dehors ${ }^{2}$ , tão caro para o balé clássico, revelavam que minha anatomia não era muito favorável àquela dança. Sempre fui, como os estudos sobre moda e etiqueta nomeiam, o tipo triangular, isto é, quadris mais largos que os ombros. De certa 
forma, esta sempre foi uma de minhas marcas registradas desde a infância, segundo relatos de familiares. Então, eis que surge uma frustração: eu não servia para dançar. Foi necessário um longo período para que eu compreendesse que não era bem assim, mas que, de certa forma, havia uma dança - entre tantas outras - que não me servia bem, o balé clássico. Parti, então, em busca de outras danças, em busca de uma dança que coubesse no meu corpo.

Nesta busca, o tão inadequado balé clássico passou anos escondido, até que o contato com a dança de mestre-sala e porta-bandeira ativou novamente posturas e movimentos de braços que eu julgava ter abolido de meu repertório. No encontro com o samba, reconciliei-me com o balé.

Mestre Manoel Dionísio afirma que o balé clássico pode ser muito útil a uma porta-bandeira, porém somente da cintura pra cima. $E$, se por um lado o balé clássico me cabe bem da cintura pra cima, por outro, meus quadris largos tem o potencial de garantir o equilíbrio e estabilidade necessários para portar o peso de uma fantasia de portabandeira, bem como uma bandeira presa a um mastro que deve ser sustentado pelo braço direito com a ajuda de um pequeno suporte acoplado à cintura, o chamado talabarte.

Entretanto, nem sempre tive essa compreensão. Ela só me foi de fato possível a partir do momento que vivenciei a experiência como porta-bandeira do Auto do Círio. Ao vestir pela primeira vez a saia rodada de meu traje ${ }^{3}$ e executar os primeiros giros, entendi que ali era preciso firmar os pés no chão, pensar no enraizamento, na conexão com a terra. Ao mesmo tempo, ao colocar a parte de cima do traje, um corselet ${ }^{4}$, imediatamente me projetei para o alto, adotando, deste modo, uma postura de ocupação das dimensões superior e inferior de meu corpo, por onde transitava uma energia mobilizadora que promovia a interação e integração entre o chão e o céu. Reporteime aos braços e cabeças do balé clássico, mas meus quadris, sem muito esforço, balançavam sutilmente como os de uma baiana que desce uma ladeira, garantindo o movimento e a sustentação de minha saia rodada.

Partindo dessa experiência, sublinho aqui os conceitos de "estado de corpo" e "estado de consciência" (BIÃO, 2009), compreendendo que, a partir desta experiência, alterações foram percebidas em meu ser, de modo que passei a operar de um modo distinto daquele mais habitual, numa experiência diferenciada de consciência do espaço e de mim mesma. Naquele momento materializei fisicamente, por meio das sensações percebidas, as matrizes estéticas da dança de porta-bandeira. Da cintura pra cima, uma figura da corte europeia do século XVI; da cintura pra baixo, uma negra escrava nas ladeiras do Pelourinho, em Salvador. Da cintura pra cima, matriz europeia; da cintura pra baixo, matriz africana. Da cintura pra cima, balé clássico; da cintura pra baixo, samba. Anatomia que se converte em movimento. Vida que se transforma em dança.

Essa aparente dicotomia, longe de reforçar o distanciamento cultural entre as matrizes, quer mesmo é reafirmar a interdependência entre ambas, pois é na compreensão de uma aparente divisão anatômica que, em colaboração, os referenciais africanos e europeus tornam viável a existência desta dança em mim. Esta aproximação entre "opostos" é, portanto, uma forma de mobilização do meu ser cênico dançante.

Desse modo, acredito ser possível aqui associar a noção de matriz ao conceito motriz, pois conforme esclarece Ligiéro (2011, p. 111), “o adjetivo motriz, do latim motrice de motore, que faz mover, é também substantivo, classificado como força que provoca ação, mas também uma qualidade implícita do que se move e de quem se move". Na dança de porta-bandeira por mim experimentada, as matrizes estéticas são também motrizes, isto é, foças que mobilizam minha construção coreográfica; forças sem as quais não seria possível perceber a relação de complementaridade existente entre chão e céu e, claro, entre as metades superior e inferior de minha anatomia. Sem esta compreensão não seria possível encontrar os mecanismos de construção da minha dança.

\section{DANÇA IMANENTE E A DANÇA DE MESTRE-SALA E PORTA-BANDEIRA}

Vivenciar a dança de mestre-sala e portabandeira no Auto do Círio não é uma experiência artística que se encerra com a encenação. Pelo 
contrário, a encenação é apenas a passagem por uma etapa de algo que já vem sendo construído em minha práxis como artista-professorapesquisadora. Dançar como porta-bandeira é o toque que faltava para reforçar meu argumento de que a dança não está desvinculada do corpo que dança; ela reflete o próprio corpo que dança. E mais, assim como qualquer corpo pode dançar, qualquer coisa pode vir a ser dança.

No tocante à dança de mestre-sala e portabandeira, a particularidade de quem dança é o componente diferencial, aquilo que distingue e dá notoriedade a um casal. Arianne Pimentel, em sua pesquisa de mestrado, defende a existência de uma dança autoral na medida em que, ser mestre-sala e porta-bandeira requer de quem dança a criação de um estilo pessoal, ou, como aponta Gonçalves (2010), um estilo próprio.

Seja pelo estilo próprio, seja pela dança autoral, o que me instiga diante da dança de mestre-sala e porta-bandeira é o fato de estar diante de um saber transmitido pelas vias da cópia e repetição, mas que não se sustenta na imitação restrita daquilo que se copia. Sinto-me diante de uma contradição verdadeiramente mobilizadora para a concepção de dança por mim desenvolvida, a qual denomino dança imanente.

Desde a realização de minha pesquisa de doutorado tenho argumentado acerca da existência da dança imanente como práxis que prima pela autonomia do corpo dançante. A partir deste pensamento-fazer procuro incentivar dançarinos a se colocarem no movimento. Não parto de vocabulários de movimento existentes a priori e, portanto, não ensino este ou aquele "passo de dança", mas oriento a pesquisa de movimentos, instigo e contribuo na edição do material desenvolvido, recortando e colando peças de movimento até formar, em parceria com o dançarino, a coreografia que ele irá executar. Deste modo, busco instigar em meus alunos/ dançarinos a construção de vocabulários que, inevitavelmente, tem relação com suas histórias de vida e experiências de movimento anteriores, sejam elas provenientes de gêneros de dança ou não. Assim, na dança imanente não importa a procedência do vocabulário de movimentos de quem dança, mas como este é manuseado na criação e execução de uma dança.
Articulada à noção de imanência e plano de imanência em Deleuze e Guattari (1992), a dança imanente vale-se das particularidades e histórias de vida de quem a dança e, logo, é construída pelos seus próprios praticantes, tidos, portanto, como matéria-prima para a criação artística. Não há, nesta perspectiva, uma técnica de dança préestabelecida, mas sim uma construção técnica dada a partir de estímulos gerados pelo coreógrafo, os quais podem advir ou não de padrões técnicocorporais pré-existentes em dança. (...). A criação do movimento a ser dançado é como uma coleta de dados que, após selecionados individualmente por cada dançarino, são compartilhados e editados naquilo que se torna a coreografia. Trata-se, portanto, de um fazer que se constroi coletivamente, refletindo a interdependência dos participantes no processo de criação (MENDES, 2014, pp. 7-8).

A dança imanente enquanto práxis cênica é, então, uma construção e, deste modo, ela é também uma proposição metodológica para o ensino e criação em dança. Ela não existe previamente enquanto técnica de dança, como o balé clássico ou outros gêneros de dança já consolidados. Ela é uma dança sem gênero, embora tenha inspiração em princípios da pós-modernidade coreográfica, como a multiplicidade e a liberdade de criação (SILVA, 2005). É uma dança devir (DELEUZE, 1992), uma potência do corpo que dança, extraída a partir de um procedimento coreográfico a que chamo "dissecação artística do corpo" (MENDES, 2010). Nesta perspectiva, a dança imanente materializa-se na medida em que dançarino e coreógrafo empenham-se em agir conjuntamente em prol de uma invenção coreográfica.

Quando formulei este pensamento-fazer em dança não me importei em chegar a um lugar em que determinados movimentos obrigatórios precisassem ser aprendidos e, por fim, dançados, haja vista que a dança, em minha concepção, pode vir de qualquer lugar. As vivências com a dança de mestre-sala e porta-bandeira, contudo, colocam-me diante da lida simultânea com o paradoxo há pouco referido, isto é, a necessidade de estar atenta à pré-existência de um vocabulário de movimentos obrigatórios composto de giros, cortejos e riscados, entre outros, e a liberdade de manusear estes em situações de ensino e aprendizagem de um gênero de dança específico.

Ao aproximar a dança de mestre-sala e portabandeira da dança imanente verifico, sobretudo na questão da autonomia, valores e princípios 
semelhantes no fazer metodológico. A noção de estilo, tão prezada pelos praticantes da dança de mestre-sala e porta-bandeira, assemelha-se sobremaneira a ideia de movimento autônomo (MENDES, 2010), comum à dança imanente. $\mathrm{Na}$ dança imanente, o dançarino, também chamado de intérprete-criador, é incentivado a desenvolver autonomamente a criação de seu repertório de movimentos, o qual poderá ou não tornarse coletivo, a depender do processo de criação. $\mathrm{Na}$ dança de mestre-sala e porta-bandeira a noção de estilo está ligada não exatamente a criação de um repertório de movimentos, mas a execução de um repertório pré-existente, o qual é mais ou menos dado aos bailantes desta dança. Instiga-me pensar como a ideia de uma dada sistematização em dança funcionaria na práxis da dança imanente, se é que já não funciona, em alguma medida.

Partindo desta reflexão e ponderando as experiências vividas em minha lida artística, especialmente como porta-bandeira do Auto do Círio, observo que copiar e repetir não são ações fortuitas em que o dançarino precisa, como uma máquina, reproduzir de forma exata aquilo que Ihe é solicitado. Admito que por muito tempo, após afastar-me do balé clássico, tive preconceito com metodologias de ensino da dança pautadas em estratégias de cópia e repetição. Acreditava que o estímulo à autonomia criativa do dançarino apenas pudesse ser dado a partir de estratégias metodológicas que the permitissem inventar coisas novas.

Contudo, ao vivenciar a dança de mestre-sala e porta-bandeira entendo mais claramente de que maneira a invenção articula-se à história de vida, ainda que haja um repertório gestual a ser executado. Não falo da invenção de passos ou movimentos diferentes e fora dos padrões exigidos pela dança, mas da invenção do meu próprio modo de dançar estes padrões (estilo pessoal ou estilo próprio), o que, a meu ver, pode ser aplicado a qualquer gênero de dança, sendo a compreensão e autoconhecimento da anatomia um dos caminhos possíveis para agenciar a história de vida de quem dança à sua criação em dança.

Nesse sentido, é pertinente não somente investigar os elementos históricos da vida de quem dança, mas encontrar estratégias de mobilização destes no sentido de construir a dança para a cena. No caso da experiência aqui refletida, esta mobilização se dá pelo reconhecimento estrutural da anatomia de uma porta-bandeira. Contudo, este reconhecimento não pode ser a atividade fim do processo de criação. Ele é apenas o disparo deste processo, e deve ser manuseado pelo corpo para criar outro corpo: o corpo que dança.

Em meu processo particular, a compreensão da anatomia é imageticamente traduzida na relação corpo e espaço, chão e céu, a qual é, também, uma espécie de metáfora das matrizes africana e europeia, próprias da dança. Entretanto, esta mesma metáfora é o que me dá a esperada diferenciação nos estados de corpo e consciência na medida em que encontro, nas matrizes, as motrizes para a apropriação de mim mesma na execução do repertório de movimentos comuns à dança. Assim, o estilo próprio, aquilo que distingue uma porta-bandeira, encontrase na própria construção coreográfica, pois a assinatura pessoal é criada na relação entre as matrizes estéticas da dança e a minha anatomia.

É claro que não espero, com isto, apontar uma fórmula para encontrar o estilo próprio de qualquer porta-bandeira. Não se trata de uma receita para tal. Este foi o modo como agenciei estratégias para a criação de meu estilo próprio ao atuar como porta-bandeira do Auto do Círio. Neste sentido, é válido ressaltar que o Auto do Círio não é uma escola de samba. Embora congregue uma comunidade de artistas que, juntos, caminham em cortejo embalados por samba e enredo específico, não se caracteriza como um desfile carnavalesco, mas como prática espetacular embalada pelo carnaval, pelo teatro de rua e pela religiosidade. Isto significa que, apesar de eu já ser uma porta-bandeira, ainda não sou porta-bandeira de uma escola de samba. Mais uma vez, aqui, reconheço meu lugar de agenciadora, mediadora entre matrizes. Nem bailarina clássica, nem sambista, porta-bandeira. Nem espetáculo, nem carnaval, Auto do Círio. Nem dança imanente, nem dança de mestre-sala e porta-bandeira, dança de mestre-sala e portabandeira do/no Auto do Círio.

Os desdobramentos da problemática parecem infindáveis, o que os torna ainda mais envolventes. Particularmente, como artista-professora- 
pesquisadora, minha intenção é apresentar essas reflexões como um modo de pensar sobre uma abordagem metodológica possível em dança. Trata-se de uma possibilidade não apenas para o ensino e aprendizagem da própria dança de mestre-sala e porta-bandeira, mas talvez sirva como abertura para outras experiências de criação coreográfica, independentemente de gêneros de dança, mas comprometidas com a história de vida de quem dança, tal como proponho na práxis da dança imanente.

De todo modo, estas elucubrações, partindo de uma experiência vivida por mim como portabandeira, me fazem compreender que a dança, a minha dança, não é tão rigorosa quanto um exame da Royal Academy ${ }^{5}$, nem tão ansiosa por liberdade como os movimentos de Isadora Duncan ${ }^{6}$. Danço a disciplina do balé clássico e o desprendimento de uma sessão de contato-improvisação ${ }^{7}$. Danço uma dança de giros que renovam o ir e vir da minha existência e a minha resistência. Danço o amor, danço o samba, danço a fé. Hoje sou uma porta-bandeira e danço a minha própria vida.

\section{NOTAS}

1. Clara Pinto é uma personalidade da dança paraense. Fundadora da escola que leva seu nome, atua no mercado desde os anos 1970.

2. Posição de rotação externa que vai da articulação do quadril aos tornozelos e que se caracteriza como princípio elementar para a dança clássica, conferindo às bailarinas a popular posição de pés "dez pras duas", isto é, pés voltados para fora, lembrando a posição dos ponteiros de um relógio ao marcar 13 horas e 50 minutos.

3. Meu traje de porta-bandeira, assim como o de meu mestre-sala, Ercy Souza, foram idealizados pela carnavalesca Cláudia Palheta e executados por outras duas pessoas. Curiosamente, a saia foi confeccionada por um negro, chamado Marco Antônia Alcântara, carnavalesco atuante em Belém e a parte de cima, pelo estilista Ney Lopes, especializado em confeccionar vestidos de baile para mulheres. Considero que o traje tenha sido de fundamental importância para despertar o reconhecimento e compreensão das matrizes estéticas da dança.
4. Cinta modeladora que lembra os trajes da corte europeia.

5. Royal Academy of Dancing é um método inglês de ensino do balé clássico adotado por várias escolas de dança do mundo. Anualmente os alunos são submetidos a exames, pois o curso prevê a transição de níveis, dos básicos aos mais avançados.

6. Pioneira da dança moderna que preconizava o ideal de liberdade em contraposição à rigidez do ballet clássico.

7. Técnica de movimento que opera com a improvisação a partir do contato entre corpos.

\section{REFERÊNCIAS}

BIÃO, Armindo Jorge de Carvalho. Etnocenologia e a cena baiana: textos reunidos. Salvador: $P \& A$ Gráfica e Editora, 2009.

DELEUZE, Gilles e GUATTARI, Felix. 0 que é a filosofia?. São Paulo: Editora 34, 1992.

FERREIRA, Felipe. 0 livro de ouro do carnaval brasileiro. Rio de Janeiro: Ediouro, 2004.

GONÇALVES, Renata de Sá.. A dança nobre do carnaval. Rio de Janeiro: Aeroplano, 2010.

LIGIÉRO, Zeca. Corpo a corpo: estudo das performances brasileiras. Rio de Janeiro: Garamond, 2011.

MENDES, Ana Flávia. Dança imanente: uma dissecação artística do corpo no processo de criação do espetáculo Avesso. São Paulo: Escrituras, 2010.

SANTA BRÍGIDA, Miguel. o sagrado sorrizo de Selmynha: a dança do mestre-sala e da portabandeira na cena afro-carioca. Repertório, Salvador, n) 19, p.18-25, 2012.2. UFBA, 2012. 


\section{SOBRE A AUTORA}

Ana Flávia Mendes Sapucahy é artista-professorapesquisadora. Pós-doutora em Artes Cênicas (PPGAC - UNIRIO). Doutora e Mestra em Artes Cênicas (PPGAC-UFBA). ProfessoradaUniversidade Federal do Pará (Instituto de Ciências da Arte/ PPGARTES/ Escola de Teatro e Daça). Fundadora e diretora artística da Companhia Moderno de Dança. Autora dos livros: Gesto transfigurado; Dança imanente e $A$ dança imanente no ensino e criação em artes cênicas. Organizadora dos livros: Abordagens criativas na cena e Ensaios de uma Companhia (Pós)Moderno de Dança. Coordena o grupo de pesquisa Coreoepistemologias. Foi contemplada com o Prêmio FUNARTE de Dança Klauss Vianna em 2006, 2008, 2009, 2011, 2013 e 2015, com a Bolsa de Produção Crítica em Artes da FUNARTE em 2008 e com a Bolsa de Pesquisa, Experimentação e Criação Artística do Instituto de Artes do Pará em 2010. Possui experiência na área de Artes, com ênfase em Artes Cênicas, atuando principalmente no campo das poéticas em dança. Contato: anaflaviadanca@gmail.com 


\title{
CINEMA E IDENTIDADE CULTURAL BRASILEIRA: POSSÍVEIS REFLEXÕES PARA USO DE FILMES EM SALA DE AULA
}

\author{
Walace Rodrigues \\ Cristiano Alves Barros \\ UFT-TO
}

\begin{abstract}
Resumo
O foco deste artigo é o uso do cinema enquanto "reflexo" de uma sociedade e encarado enquanto produto cultural brasileiro. Busca-se refletir sobre como o cinema pode funcionar em sala de aula do Ensino Médio enquanto gerador de informações sociais, históricas e culturais de uma época não vivida pelos estudantes. Os objetos de análise deste escrito serão os filme Terra em transe, Macunaima e Bye bye Brasil, já que estes filmes se relacionam diretamente ao movimento Tropicalista, algo que os estudantes do Ensino Médio atual não chegaram a vivenciar. Encarando o cinema enquanto produto da cultura de um país, os estudantes poderão melhor compreender quais os elementos que nos marcam enquanto brasileiros e como o cinema brasileiro pode ajudar no entendimento da formação da identidade cultural de seu próprio país.
\end{abstract}

\section{Palavras-chave:}

Cinema; cultura; identidade.

\section{INTRODUÇÃO}

Encarar o cinema enquanto produto cultural de nosso país é ligá-lo à questão da identidade nacional, ou seja, é perguntar: Quem somos enquanto brasileiros? O que nos define e nos diferencia culturalmente de outros países? Há realmente uma identidade cultural nacional para um país tão vasto quanto o nosso? Essas questões revelam somente um começo de discussão sobre a identidade nacional pela via das produções artísticas.

Assim, este artigo busca discutir pontos relevantes em relação ao uso do cinema na educação escolar e compreender esta forma artística enquanto produto cultural que estimula um pensar sobre a identidade cultural brasileira e suas concepções históricas. Por

\section{Abstract}

This paper focus on the use of cinema as a "reflexion" of a society and as a cultural product. Hereby, we search to reflect upon how cinema can be used in High School classrooms as a generator of social, historical and cultural informations regarding a period that the students did not live themselves. The analysis of this paper focus on the films Terra em transe, Macunaima and Bye bye Brasil, as these films relate to the Tropicalist artistic movement, something that the actual students at High School did not presenced. Looking ath the cinema as a cultural product of a country, students can better understand which elements mark us as Brazilians and how Brazilian cinema can help us to understand the formation of a cultural identity of their own country.

Keywords:

Cinema; culture; identity.

isso foram escolhidos os filmes Terra em transe, Macunaima e Bye bye Brasil para fomentar estas discussões, já que tais filmes buscam olhar para os vários brasis que compõem o Brasil.

Portanto, podemos encarar o cinema brasileiro como um produto cultural que nos revela e que deixa ver claramente uma identidade nacional própria, revelando uma forma única de sermos através das artes (enquanto componente cultural), uma maneira rica de pensar e agir artisticamente.

\section{O USO DO CINEMA NA ESCOLA E OS FILMES ESCOLHIDOS}

Vale lembrar que o conceito de identidade cultural nacional não tem uma única definição, já que se 
coloca, sempre, como historicamente mutável e dinâmico, portanto de difícil compreensão e definição exata. No entanto, podemos trabalhar com ele enquanto uma forma de identidade nacional que define um povo e sua maneira de ser e estar no mundo.

Ainda, este termo composto de "identidade cultural brasileira" busca compreender as nuances culturais que fazem de nós brasileiros um grupo que se relaciona e que interioriza nossos próprios costumes, crenças, instituições, artes, etc. A cultura lida com a esfera do aprendizado, pois é ensinada e aprendida. Citamos, aqui, uma passagem de Claude Lévi-Strauss (1989) sobre o que seria cultura e sociedade:

\begin{abstract}
...a cultura designa o conjunto de relações que, em uma dada forma de civilização, os homens mantêm com o mundo, e a sociedade designa mais particularmente as relações que os homens mantêm entre si. A cultura fabrica organização: cultivamos a terra, construímos casas, produzimos objetos manufaturados...(LÉVI-STRAUSS apud CHARBONNIER, 1989, p. 35).
\end{abstract}

Podemos dizer, também, que a cultura não somente "fabrica organização", mas fabrica, também, identificação. É neste sentido que este artigo busca trabalhar com a identidade cultural brasileira. Também, podemos compreender este conceito de identidade cultural brasileira como "algo" que une em relação pessoas de uma mesma comunidade nacional.

Ainda, encarar o cinema enquanto produto cultural nos faz pensar não somente em seu valor enquanto mercadoria de troca, mas em seu valor para a formação de uma forma de pensar sobre si mesmo, já que um produto cultural é fruto de um complexo mais amplo que abarca a sociedade que o produziu e o consume. Vale ressaltar aqui que o termo "produto cultural" provem dos estudos da Escola de Frankfurt, conforme nos mostram Marita Sturken e Lisa Cartwright (2005):

Indústria cultural - Termo usado pelos membros da Escola de Frankfurt, em particular por Theodor Adorno e Max Horkheimer, para indicar como o capitalismo organiza e homogeniza a cultura, dando aos consumidores culturais menos liberdade para construir seus próprios significados. Horkheimer e Adorno viram a indústria cultural como gerando cultura de massa como uma forma de fetichismo da mercadoria que funciona como propaganda para o capitalismo industrial. Eles viram toda a cultura de massa como ditada pela fórmula e repetição, incentivando conformidade, promovendo a passividade, traindo seus consumidores daquilo que é prometido e promovendo pseudoindividualidade (STURKEN; CARTWRIGHT, 20015, p. 352, tradução nossa).

Também, podemos nos perguntar: Seria o cinema uma estrutura comunicativa e estética capaz de educar seu público, isto é, rompendo os próprios limites da sala de exibição fílmica e construindo novos espaços no imaginário de, por exemplo, estudantes do Ensino Médio? Estudos recentes nos informam que a escola vem se aproximando cada vez mais do cinema, principalmente quando ambos se relacionam numa atuação pedagógica. É nesse ponto que o autor Marcos Napolitano (2003) descreve que:

\footnotetext{
Trabalhar com o cinema em sala de aula é ajudar a escola a reencontrar a cultura ao mesmo tempo cotidiana e elevada, pois o cinema é o campo no qual a estética, o lazer, a ideologia e os valores sociais mais amplos são sintetizados numa mesma obra de arte. Assim, dos mais comerciais e descomprometidos aos mais sofisticados e "difíceis", os filmes têm sempre alguma possibilidade para o trabalho escolar (NAPOLITANO, 2003, p. 11-12).
}

De fato, as possibilidades de ensino através do cinema vão muito além da própria estruturação física e curricular da escola. A disponibilidade de materiais pedagógicos em outras plataformas áudio-visuais facilita ainda mais o trabalho do professor interessado em utilizar-se do cinema em sala de aula.

É nesse sentido que o professor deve estar atento às especificidades experienciadas na escola e às vivências de seus estudantes. Também, é a partir de um planejamento cuidadoso que o docente consegue objetivar uma forma de trabalhar com o cinema em sala de aula, desde sua caracterização no espaço escolar até mesmo em relação a sua articulação com os conteúdos curriculares.

Além disso, lembramos que o planejamento docente, com o uso de recursos áudio-visuais, deve atentar-se, principalmente, às condições de aprendizagem dos alunos, a fim de mediar suas interpretações através dos filmes exibidos. Neste caso, acreditamos que o professor deve direcionar as discussões para os pressupostos temáticos da aula, revelando nuances escondidas nas obras fílmicas que sirvam para melhor compreender a história e a cultura brasileiras. 
No caso deste artigo, acreditamos que o cinema pode ser utilizado enquanto forma de instruir sobre os processos envolvidos na formação de uma identidade cultural brasileira, principalmente de estudantes do Ensino Médio, cuja maturidade possibilita um trabalho mais efetivo e direcionado sobre a diversidade cultural de nosso país.

O cinema, como metodologia crítica e instigadora, serve como base para discussão em sala de aula, levantando possibilidades e especificidades de compreensão de nossa forma de ser enquanto brasileiros e como isto se mostra nas criações artísticas (cinematográficas neste caso) nacionais. De acordo com autor Marcos Napolitano (2003), deve haver uma coerência entre temáticas estudadas e obras fílmicas para que haja um enriquecimento de conhecimentos para todos:

Tenha em mente um conjunto de objetivos e metas a serem atingidas, procurando aprimorar os instrumentos de análise histórica e fílmica. Sugerimos que o uso do cinema na sala de aula seja sistemático e coerente, e isso implica que os filmes sejam articulados entre $\mathrm{si}$, sobretudo quando o espírito da atividade é a análise do filme como linguagem e fonte de aprendizado, mais do que catalisador de discussões (NAPOLITANO, 2003, p. 79).

É neste sentido que este escrito tenta mostrar que os estudantes do Ensino Médio podem ser privilegiados no uso coerente e consciente de obras de cinema nacional para a compreensão de movimentos históricos e culturais desconhecidos por eles e de extrema importância para nossa formação enquanto brasileiros. Utilizando uma passagem de Roseli Pereira Silva (2007), podemos compreender como o cinema pode auxiliar os professores em relação a uma reflexão crítica da história cultural brasileira:

A experiência estética que o cinema proporciona abre-nos, sem dúvida, para uma compreensão mais radical da realidade e do ser humano. É uma obra de arte com a qual nos relacionamos para iluminar a nossa percepção do mundo e, claro, é uma via de acesso a nós mesmos; uma convocação instigante que nos faz repensar nossas atitudes e reavaliarmos nossos valores; uma provocação inquietante para questionarmos possíveis conivências nossas com a falta de criatividade, com a mediocridade, que é mostrada, muitas vezes, em comportamentos rígidos, intolerantes, niilistas, autoritários e materialistas. Talvez seja precisamente nesse ponto que descobrimos, atrás dessas possibilidades estéticas, as possibilidades educativas e éticas do cinema (SILVA, 2007, p. 52).
Um destes períodos que podem ser estudados através do cinema é o período da ditadura militar brasileira (de 1964 a 1985), período sócio histórico-cultural tão pouco conhecido e tão pouco estudado pelos jovens de hoje. E é dentro deste período histórico se coloca um dos mais relevantes movimentos para a cultura brasileira no século XX: o Tropicalismo.

O movimento tropicalista se dá durante a ditadura militar no Brasil. A ditadura militar foi instaurada em 1964 e oficialmente terminada em 1985, sendo que o período mais autoritário aconteceu depois da criação do Ato Institucional número 5 (Al-5), de 13 de dezembro de 1968, que suspendeu todos os direitos civis dos cidadãos. A partir deste ato, a vida cultural brasileira mudaria de rumo com a forte influência da censura pública sobre todos os campos culturais. Utilizamo-nos de uma passagem de Randal Johnson (2004) que clarifica este período da história brasileira dando especial atenção à literatura:

O golpe de estado militar de 1964 que deu inicio a vinte e um anos de regime ditatorial obviamente teve um grande impacto na literatura e cultura brasileiras. Numerosos trabalhos de ficção têm explorado o impacto e ramificações do autoritarismo, assim como o movimento de resistência que se ergueu contra este regime militar (JOHNSON, 2004, 131, tradução nossa).

Durante esse período marcado pela ditadura e pelo Al-5 surge o movimento Tropicalista. Inovando pelas roupas, cabelos, músicas, influências, instrumentos musicais e referências culturais, sociais e políticas. O “...tropicalismo capta a vertiginosa espiral descendente do impasse institucional que levaria ao Al-5" (WISNIK, 1979, 16) e a canção "Tropicália" pode ser vista como uma boa representante deste período histórico.

As várias referências culturais "conflitantes" utilizadas pelos tropicalistas dão 0 toque interrogativo do movimento: somos isso, ou aquilo, ou tudo isso, ou nada disso, ou parte disto, ou parte daquilo? Nessa busca artística os tropicalistas focam-se na ambiguidade de significados e na pluralidade de interpretações, buscando criar uma ideia de desordem criadora, regeneradora. Conforme texto de Walace Rodrigues (2014a), pode-se compreender alguns mecanismos críticos dos tropicalistas: 
A "utilidade do aparentemente inútil" se torna uma outra arma para os tropicalistas. O que estava esquecido no passado volta a fazer parte do presente, re-inventado, re-modelado, anacrônico e fazendo referência às heranças culturais. Também, a ambiguidade da alegoria dá essa liberdade de criação enquanto figura indefinida e dúbia, ambiguidade esta que dá liberdade para criar o contemporâneo com as "ferramentas" deixadas pelos criadores anteriores quase esquecidos. Os tropicalistas, assim, trabalharam com as ideias de inclusão exclusiva e de exclusão inclusiva; utilizando canções antigas, mas que não faziam parte do "estilo" tropicalista. Assim, pela utilização inteligente das mais variadas referências à cultura brasileira, os Tropicalistas transformaram essas referências em signos, e estes signos em referências (RODRIGUES, 2014a, p.84).

Uma importante figura criadora de sentido para os tropicalistas foi a alegoria. A alegoria, por ser uma figura dúbia e instável, está aberta à várias interpretações, esconde uma verdade oculta, um saber escondido que depende de um sentido exterior.

Um bom exemplo da utilização do conceito de alegoria pode ser visto no filme Terra em Transe (de 1967), de Glauber Rocha, devido a sua instabilidade da aproximação e distanciamento da câmera e "... as limitações da política progressista no Brasil e a necessidade de utilizar a paródia e a sátira para refletir sobre a crise política e a herança cultural" (cf. AGUILAR, 2005, 124). O filme Terra em Transe dá o tom daquele movimento que ficaria conhecido culturalmente como Tropicalismo.

Terra em Transe apresenta uma discussão política que será expandida pelo movimento tropicalista na área da música. Apesar de Terra em Transepoder ser encarado como uma parábola do Brasil do começo da ditadura militar, o filme se mostra como uma clara crítica a todas as esferas políticas brasileiras, tanto de esquerda, quanto de direita, deixando ver as "armadilhas" do poder, a prostituição, a pobreza do povo explorado, entre outros pontos muito próximos da realidade brasileira. $O$ filme se coloca como um importante elemento artístico que busca, através da crítica político-social, fomentar discussões sobre a vida brasileira da década de 1960 , nossa maneira de ser e encarar o mundo.

Em uma fictícia república, chamada de Eldorado no filme, políticos, jornalistas, prostitutas, empresários, tecnocratas, progressistas, entre outros personagens, são colocados em uma trama de poder, riqueza, miséria e ambição. As filmagens em preto e branco dão maior força expressiva às cenas, causando uma certa distância e exacerbando a crueza da história. Antônio Lima Neto (2012) mostra a relação do filme com seu período histórico:

Do período que se estende da deflagração do golpe até o Al-5, havia a possibilidade de falar contra o regime, ainda que com certa parcimônia. Contudo, vários trabalhos artísticos foram mutilados devido à intervenção da censura. É durante essa época que Glauber Rocha inicia a criação e produção de sua obra mais emblemática, Terra em Transe, objeto deste estudo. Assim, todas as manifestações artísticas que se desenvolveram nesse espaço de tempo denunciavam, de uma forma ou de outra, os desmandos do regime. A arte passou a ter um papel preponderante de resistência e denúncia. A bossa nova, que atingira um patamar nunca antes alcançado pela música brasileira, naquele momento tinha se tornado fonte de alienação para os mais radicais. Consequentemente, a época tornara-se, também, mais radical (LIMA NETO, 2012, p.6).

Ainda, de acordo com o professor José Manuel de Sacadura Rocha (2010), e como retratado em Terra em transe, nosso modelo de identidade nacional foi sempre imposto de cima para baixa, dos poderosos para a população. Em nossa análise, é o movimento tropicalista que critica este modelo de formação identitária e inclui um novo modelo baseado em referências culturais díspares, ambíguas, conflitantes e que inclui as contribuições culturais populares. Colocamos, aqui, uma passagem de José Manuel de Sacadura Rocha (2010) sobre sua visão de identidade nacional:

Há de se apontar aqui a crítica a uma pretensa capacidade de juntar tendências e visões de "Brasis" que muitas vezes estão separadas por tradições históricas e sociais distintas, impedindo a formação de uma Identidade Nacional que se dá do indivíduo para a sociedade. No Brasil é o inverso, o trajeto percorre da totalidade para o indivíduo, como forma imposta pelo Estado, e não desenvolvida de maneira consciente pelas massas populares; logo, como atender aos anseios sociais? (ROCHA, 2010, p. 88).

Outraobracinematográficaqueajudaacompreender a formação de uma identidade cultural brasileira seria o filme Macunaima (de 1969), de Joaquim Pedro de Andrade. O filme retrata o nascimento, crescimento e parte da vida de Macunaíma.

Este personagem-título do filme se aproxima de um anti-herói, um herói sem nenhum caráter, bem ao gosto irônico dos brasileiros. Macunaíma nasce na mata, como um indígena, e se coloca, na visão de Mário de Andrade, o escritor modernista 
do livro (de 1928) que inspirou o filme, como a representação do povo brasileiro.

Macunaíma é um homem preguiçoso e sua frase jargão é "Ai, que preguiça!". Adora uma rede e busca seu amuleto muiraquitã, que havia recebido de sua falecida esposa, a índia Ci. Torna-se branco e muda-se para a cidade de São Paulo para procurar seu amuleto. Em São Paulo se envolve em várias aventuras e estrepolias. Ama, odeia, brinca, foge, ri, enfim, vive. No final do filme Macunaíma reavê seu talismã e regressa para sua mata.

A obra cinematográfica traz as várias influências culturais das três raças que compunham o imaginário da época modernista. Essa composição étnica que valoriza o que era indígena, negro e branco é colocada, no filme, como uma das facetas culturais de nós brasileiros. Macunaíma adora fazer amor e gosta de uma vida "mansa" (de nenhum trabalho).

O estereótipo de preguiçoso, dado ao povo brasileiro, no livro de Mário de Andrade, refletem os resquícios dos preconceitos dos colonizadores em relação aos brasileiros. Obviamente há equívocos e pontos questionáveis nesta representação, porém o filme deixa ver, claramente, a forma de compreender a identidade cultural brasileira da primeira metade do século XX. Walace Rodrigues (2014b) nos dá mais informações sobre a referida obra fílmica e a literária:

O filme mostra claramente os mais diversos traços de nossa formação cultural: o indígena, o negro, o branco, o rural, o urbano, o deslumbramento, a preguiça, entre outros. Este filme se enquadra no período inicial do movimento tropicalista, refletindo a busca por uma identificação cultural nacional através da confluência de representações de coisas "tipicamente" brasileiras. Não podemos esquecer que as obras de Mário de Andrade serviram de inspiração para os tropicalistas, já que este pesquisador buscou, verdadeiramente, compreender o Brasil, viajando pelo país para coletar mitos, lendas, crenças, conhecer personagens interessantes, entre outras expedições. Seus trabalhos apresentam a primeira tentativa de tradução do Brasil, antes mesmo do mito da democracia racial brasileira de Gilberto Freyre, na obra "Casa Grande \& Senzala", de 1933 (RODRIGUES, 2014b, p. 6).

O filme Macunaima se coloca como uma obra cinematográfica satírica, onde nosso herói faz suas estrepolias pelas matas, nas águas e nas cidades. Há uma forte via humorística nesta obra fílmica, porém sem perder seu poder de contestação cultural. A sátira se coloca como mecanismo crítico dos mais refinados, requisitando conhecimentos prévios dos aspectos da cultura brasileira e fomentando relações inteligentes.

Em relação às várias inter-conecções entre obra literária e obra cinematográfica, como no caso do filme Macunaima, a professora Eliana Yunes (2013) nos deixa ver que as obras de arte que se utilizam de diferentes linguagens artísticas devem ajudar a divulgar uma a outra, reforçando convergências e divergências críticas:

\begin{abstract}
Constatamos que $\mathrm{O}$ Cinema olha A Literatura como fonte de inspiração, e de divulgação ideológica de cânones ocidentais, como matéria-prima de filmes, numa permanente busca de elementos que despertem a atenção do público cinéfilo, interessa saber como o Cinema aprender e divulga tanto - leitor com a própria leitura, inclusiva para o estabelecimento dos pontos de convergência e de divergência entre a literatura da obra de arte literária e a leitura da obra de arte cinematográfica, entre o leitor de uma (leitor) e o leitor de outra (espectador) (YUNES, 2013, p. 30-31).
\end{abstract}

A última obra cinematográfica a servir como elemento indagador para estudantes do Ensino Médio pode ser Bye bye Brasil (de 1979), de Carlos (Cacá) Diegues. O filme mostra as várias facetas do Brasil em uma época de exploração intensa da região amazônica.

Os interiores mais "atrasados" do país e o que há de mais "moderno", em termos urbanos e tecnológicos, são retratados no filme. As diferenças culturais e seus ambientes distintos são colocadas propositalmente no filme e deixam conhecer lugares culturais muitos distintos, podendo nos ajudar a compreender melhor nosso país. Das "maravilhas" de Brasília aos interiores amazônicos dos indígenas. Diegues deixa ver várias facetas e paisagens brasileiras desconhecidas para os habitantes do sul e sudeste do país. Essa riqueza e diversidade de paisagens se descortina diante de nossos olhos.

A fotografia do filme é de extrema importância para deixar conhecer as imagens destes brasis desconhecidos. Das imagens da caravana Rolidei pela rodovia Transamazônica até os contrastes das casas pobres de Altamira, tendo como fundo um avião levantando voo; ou da Brasília de edifícios imponentes e das casas pobres dos operários. Em Bye bye Brasil há uma tentativa de compreender o Brasil através das imagens fotográficas, como um álbum de família 
mostrando parentes que nunca vimos.

O estudioso José Manuel de Sacadura Cabral (2010) nos diz que o sentimento nacional, que ele chama de "verdeamarelismo", com o qual nos identificamos (e somente pode ser realmente sentido durante competições esportivas) é uma criação baseada em vários mitos, conforme a passagem abaixo:

Nosso vermeamarelismo é, na verdade, um mito em si mesmo, construído permanentemente por outros tantos mitos a partir de símbolos que nos colocam como especiais em alguma coisa, menos naquelas que realmente deveriam ser especiais, como moradia, saúde, educação, transporte, lazer, ou ainda honestidade, seriedade, justiça e orgulho de ser brasileiro (ROCHA, 2010, p. 76).

Neste sentido, podemos perceber que o cinema pode, de forma única, muito rica, expressiva e sensível, levar-nos a reflexões sobre o sentido e a formação de nossa identidade cultural nacional e como ela se coloca para nós, além de temas históricos e sociopolíticos importantes de serem pensados e discutidos na escola.

Pensando sobre, a inserção dessas discussões em sala de aula, propõem-se, também, outros apontamentos a partir desse poder midiático do cinema. De fato, a projeção fílmica na sua conjuntura cultural parte de um ideal capitalista que reproduz certos estereótipos acerca da nossa identidade. Não é por acaso que o padrão hollywoodiano se faz tão presente nos catálogos de filmes e nas salas de cinema. São estes filmes que influenciam e até mesmo determinam uma certa ideologia por trás das grandes industrias cinematográfica. No entanto, os três filmes propostos neste escrito fogem desse padrão cinematográfico hollywoodiano, não somente nos tópicos, mas também nas formas de abordar os temas muito brasileiros.

Nesse sentido, é importante lembrar que muitos alunos acabam assimilando o cinema a partir de uma acepção predominantemente norteamericana, logo, desconsiderando outras produções, principalmente nacionais, que fogem desse arquétipo em que o cinema é difundido.

Desse modo, abordar filmes em sala de aula exige muita conscientização acerca da veiculação do cinema, principalmente quando associado ao público de massa. Neste caso, trabalhar com o cinema brasileiro em sala de aula é, de fato, um grande desafio, já que, o cinema nacional é, para muitos brasileiros, um cinema desprestigiado.

Portanto, trazer esse acervo fílmico para o contexto escolar é também aproximar outras concepções acerca da nossa identidade enquanto produtores e divulgadores de cultura. Neste caso, muitos dos nossos alunos desconhecem essas obras e por fim acabam desconsiderando o valor estético presente nelas.

De fato, para uma geração que está habituada às grandes produções cinematográficas e aos grandes efeitos especiais hollywoodiano, dificilmente vai olhar com certo bom gosto para um filme que não dispõe de tantos recursos tecnológicos como os filmes brasileiros proposto. No entanto, o professor deve ser o incentivador de novas descobertas de saber estético, hisótico, político e cultural.

Neste caso, tanto a leitura literária quanto a (re) leitura fílmica tendem a enfatizar os mais diferentes aspectos que caracterizam a cultura brasileira. Ainda, não podemos esquecer que tanto a obra literária quanto a obra fílmica são representações. Elas não retratam a vida de forma verdadeira, mas representam esta vida através de diferentes prismas. Mais especificamente sobre a importância da representação, colocamos uma valiosa passagem de Marita Sturken e Lisa Cartwright (2005):

Através da história, debates sobre representação têm considerado se esses sistemas de representação refletem o mundo como ele é, como se eles espelhassem para nós uma forma de mímese ou imitação, ou mesmo se, de fato, nós construímos o mundo e seus significados através dos sistemas de representação que usamos. $\mathrm{Na}$ perspectiva construtivista, nós somente construímos significado do mundo material através de contextos culturais específicos. Isso acontece, em parte, através dos sistemas de linguagem (sejam eles escritos, falados ou imagéticos) que usamos. No entanto, o mundo material somente tem significado, e somente pode ser "visto" por nós, através desses sistemas de representação. Isso significa que o mundo não é simplesmente refletido para nós pelos sistemas de representação, mas que nós construímos significado do mundo material através destes sistemas (STURKEN; CARTWRIGHT, 2005, p. 12-13, tradução nossa).

Assim, o cinema, enquanto sistema de representação de realidades diversas, pode ser de extrema relevância quando usado na educação, principalmente dos estudantes do Ensino Médio, estes já em idade para compreender que os filmes são parte de um sistema de representação 
audiovisual que nos ajudam a melhor compreender quem somos enquanto brasileiros.

Também, a preocupação identitária da produção nacional atende a uma demanda de estudantes do Ensino Médio que está mais acostumada ao "olhar estrangeiro" do que ao próprio ponto de vista que mostra sua cultura. De certo modo, esse panorama vem mudando a partir das várias possibilidades de conhecimento que o meio escolar vem a trazer aos jovens atuais. Neste caso, a escola, com o auxílio do cinema, pode ajudar na formação de cidadãos plenos e no conhecimento de uma identidade cultural tipicamente brasileira.

Ainda, estes estudantes do Ensino Médio já têm maturidade bastante para compreender que o cinema é um produto cultural do qual o capitalismo tomou posse para homogenizar a cultura. É nesse sentido que o uso crítico do cinema nacional pode ajudar a fazer destes estudantes consumidores culturais com mais liberdade para construir seus próprios significados sobre o que veem.

\section{CONSIDERAÇÕES FINAIS}

Através da exposição de argumentos neste artigo, esperamos que a intenção de fazer do cinema uma ferramenta para o conhecimento histórico e social da formação cultural brasileira tenha levantado ideias e perspectivas para a utilização desta forma de arte audiovisual no Ensino Médio.

Há uma necessidade crescente de conhecimento histórico dos estudantes atuais, já que eles não viveram momentos marcantes de (trans)formação da sociedade brasileira. A exposição de fatos, representados através do cinema, pode levar a reflexões críticas sobre como a identidade cultural brasileira se forma e se modifica com o tempo e com os fatos.

Através de filmes como Terra em transe, Macunaima e Bye bye Brasil pode-se ver como todas as pessoas envolvidas com a arte do cinema, numa época de ditadura e repressão, driblaram as barreiras da censura e transformaram um produto cultural em uma arma de contestação social. Aliás, há que informar aos jovens sobre a desgraça que foi a censura de informação cultural e de notícias e a tortura sofrida por milhares de pessoas em favor da preservação de um regime que valorizava a ordem militar, a família tradicional, a propriedade privada, os valores católicos e as tradições (fossem elas quais fossem!).

Vale ressaltar, também, que o próprio contexto escolar onde esses filmes são vinculados podem apontar novos direcionamentos acerca da abordagem fílmica em sala de aula. Neste caso, problematizando as situações vivenciadas na atualidade pelos próprios estudantes. Outras fontes de comunicação midiáticas podem, também, reforçar esse discurso de identidade nacional e revelar facetas desconhecidas para os estudantes.

De fato, é a partir do contato que o público discente tem com o meios de comunicação e entretimento que podemos alçar outras reflexões sobre nós mesmos enquanto brasileiros e qual o papel da arte na nossa (re)configuração identitária e cultural, cabendo ao docente articular esses filmes brasileiros sob uma conotação menos conteudista e mais instigadora de sentidos estéticos, artísticos e culturais.

Desse modo, o papel dos filmes nacionais na educação escolar surge não como mera "ilustração da realidade", mas como ferramenta de reivindicação social através das mazelas e desigualdades viventes até hoje. Para tanto, o retrato fílmico mostra que muito desses assuntos ainda necessitam de uma abordagem mais efetiva, isto é, critiquizando os problemas sociais a fim de denunciar as possíveis causas para este paradigma cultural.

Portanto, trazer essa objetividade à sala de aula é, também, reencontrar o valor da escola nesse formação cidadã, logo, é a partir dos movimentos artísticos que se sucederam no século passado que podemos sintetizar algo sobre nossa identidade cultural brasileira e utilizar estas descobertas para análises atuais de nossa realidade histórico-cultural e sócio-política.

\section{REFERÊNCIAS BIBLIOGRÁFICAS}

AGUILAR, G. Poesia concreta brasileira: as vanguardas na encruzilhada modernista. São Paulo: Edusp, 2005.

CHARBOnNIER, G. Arte, linguagem, etnologia: entrevistas com Claude Lévi-Strauss. Campinas, SP: Papirus, 1989.

JOHNSON, R. Brazilian narrative. IN KING, John 
(ed). The Cambridge Companion to Modern Latin American Cultures. Cambridge: Cambridge University Press, 2004, pág. 119-135.

LIMA NETO, A. As Intersecções entre Cinema e História no filme Terra em Transe. IN: Revista Thema. 09 (02), 2012, ISSN: 2177-2894, pág. $1-15$.

NAPOLITANO, M. Como usar o cinema na sala de aula. São Paulo: Contexto, 2003.

ROCHA, J. M. de S. Antropologia jurídica. São Paulo: Elsevier Editora Ltda, 2010.

RODRIGUES, W. Música e ditadura: a canção "Tropicália" de Caetano Veloso e seu momento histórico. IN: Cultura Crítica. 50 anos de golpe de 64, resistência artística, ditadura miltar. Revista cultural da Apropuc-sp, n) 16, 2014a, ISSN: 19810911, pág. 75-85.

Tropicalismo e cinema na construção de uma identidade cultural nacional. IN: Cadernos de Pesquisa. UFMA, São Luís, v. 21, n). 2, mai./ago. 2014B, ISSN: 2178-2229,pág. 1-9.

SILVA, R. P. Cinema e educação. São Paulo: Cortez, 2007.

STURKen, M.; CARTWRIGHT, L. Practices of looking: an intruduction to visual culture. New York: Oxford University Press, 2005.

WISNIK, J. M. O minuto e o milênio ou Por favor, professor, uma década de cada vez. José Miguel Wisnik. IN BAHIANA, Ana Maria; WISNIK, José Miguel; AUTRAN, Margarida. Anos 70. Rio de Janeiro: Europa Editora, 1979, pág. 7-23.

\section{SOBRE OS AUTORES}

Walace Rodrigues é doutor em Humanidades, mestre em Estudos Latino-Americanos e Ameríndios e mestre em História da Arte Moderna e Contemporânea pela Universiteit Leiden (Países Baixos). Pós-graduado (lato sensu) em Educação Infantil pelo Centro Universitário Barão de Mauá SP. Licenciado pleno em Educação Artística pela UERJ e Licenciado em Pedagogia pela FIC-SP. Professor da Universidade Federal do Tocantins (UFT). Sua atual pesquisa é sobre live cinema, cidade e projeção. É membro da Associação
Brasileira de Educação a Distância (ABED), da Sociedade Brasileira de Estudos de Cinema e Audiovisual (SOCINE) - um dos coordenadores do Seminário temático "Exibição cinematográfica, espectatorialidade e artes da projeção no Brasil" e da Media Ecology Association (MEA). Entre julho de 2012 e 2013 assumiu a coordenação do curso de Cinema da UNESA - campus João Uchoa. Como artista, desenvolve trabalhos multimídia e outros produtos audiovisuais com o Duo $2 \times 4$.

Cristiano Alves Barros é mestrando do Programa de Pós-Graduação em Estudos de Cultura e Território (PPGCult) da Universidade Federal do Tocantins (UFT), campus de Araguaína, licenciado em LetrasPortuguês pela Universidade Federal do Tocantins (UFT), campus de Araguaína. 


\title{
A CONCEPÇÃO INTERVALAR NA POÉTICA PÓS-RUPTURA: UMA ANÁLISE DA SONATA N. ${ }^{\circ} 3$ DE ALMEIDA PRADO
}

\author{
Edson Hansen Sant'Ana \\ IFMT-MT
}

\section{Resumo}

Este trabalho demonstra a teorização que venho desenvolvendo nestes últimos anos (2009-2016) sobre a póetica de Almeida Prado no pós-ruptura ao tonalismo. Este texto aborda sobre o espaço multisistêmico do compositor, chamado transtonalismo, bem como trata da comprovação analítica voltada para o problema intervalar em uma das obras utilizadas para uma pesquisa mais abrangente, que se ampliou e se verificou ocorrente em mais de 100 obras do compositor. Venho propondo a superação terminológica do conceito anteriormente fundado pelo compositor como expressividade intervalar em direção a um novo termo definifo como intervalo característico. Como estudo e comprovação pontual, construo uma análise da Sonata n. ${ }^{\circ} 3$ como uma obra representante da fase Pós-Tonal, entendendo que todo esse mecanismo intervalar ocorre em obras de outras duas fases subsequentes, as fases Síntese e Pós-Moderna.

\section{Palavras-chave:}

Intervalo característico, Transtonalismo, Sistemas musicais.

\section{INTRODUÇÃO}

A preocupação central deste trabalho mantevese em verificar a importância da concepção intervalar nas fases pós-ruptura da composição de Almeida Prado. Pretendeu-se constatar se algumas hipóteses e resultados quantos aos problemas intervalares configurados a partir da pesquisa anterior (O AUTOR, 2009c), poderiam ser validados em outras obras musicais pertencentes às fases Pós-tonal, Síntese e Pós-Moderna, o que de fato se configurou nesta obra Sonata $n .^{\circ} 3$, nas Cartas Celestes / e no Noturno n. ${ }^{\circ}$ 7. É oportuno mencionar que em outras 119 obras do compositor de 130 consultadas no Centro de Documentação

\section{Abstract}

This work demonstrates the theorization that I have been developing in recent years (20092016) about the poetry of Almeida Prado in the post-rupture to tonalism. This text deals with the multi-systemic space of the composer, called transtonalism, as well as dealing with the analytical evidence focused on the interval problem in one of the works used for a more comprehensive research, which has been expanded and occurred in more than 100 works of the composer. I have proposed the terminological overcoming of the concept previously founded by the composer as interval expressivity towards a new term defining as a characteristic interval. As a study and timely verification, I construct an analysis of Sonata no. 3 as a work representative of the PostTonal phase, understanding that all this interval mechanism occurs in works of two subsequent phases, Synthesis and Postmodern phases.

Keywords:

Characteristic Interval, Transtonality, Musical Systems.

Música Contemporânea da Universidade Estadual de Campinas (CDMC-UNICAMP) foram detectadas presença marcante desse fenômeno ora denominado como intervalo(s) característico(s).

Diante da necessária revisão bibliográfica, que vem sendo realizada desde 2009, sendo estendida até ao presente momento (2009-17), e como consequência desse processo, tem sido possível firmar um posicionamento discordante quanto aos enfoques e métodos analíticos aplicados em um número considerável de pesquisas que trataram sobre as obras de Almeida Prado. Assim, pretendi que esta análise e seus resultados, pudessem ser uma alternativa em relação àquelas análises 
provenientes das tendências acadêmicas atuais de se reportarem à macro-média-micro análise de White (1994), à análise schenkeriana e à Teoria dos Conjuntos de Forte (1973).

Especificamente procurou-se obter um tipo de abordagem analítica que fosse mais diretamente oriunda da composição, ou seja, que fosse condizente com a poética de Almeida Prado. Uma análise que pudesse evidenciar a concepção intervalar que o compositor aplicou em cada uma das três obras escolhidas para a pesquisa de doutorado. Entretanto, para este específico texto, apresento somente as abordagens analíticas aplicadas na Sonata $n .{ }^{\circ}$ 3. Para tanto, relembre-se que o compositor formulou suas construções a partir de conceituações como um "novo espaço sonoro" (PRADO, 1985, p. 530-539), do que é "pandiatonal" (MOREIRA, 2002, p. 75), do seu "sistema transtonal de ressonâncias" (YANSEN, 2005, p. 212), dos "mecanismos intervalares" (NADAI, 2007, p. 117) e da "expressividade intervalar" (NADAl, 2007, p. 117), (O AUTOR, 2009c).

\section{A POÉtica de ALMEIDA PRAdO EM UM ESPAÇO "ENTRE" SISTEMAS}

Na entrevista concedida a Adriana Moreira (2002, p. 56), Almeida Prado se autodenomina tendo quatro fases composicionais: $1^{\text {a }}$, Nacionalista (1960-65); 2a, Pós-Tonal (1965-73); 3a, Síntese (1974-82);

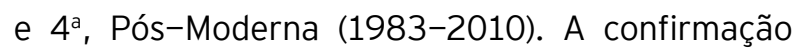
destas fases traz implícita uma preocupação de indicar as mudanças significativas quanto ao seu direcionamento estético a partir da $2^{\text {a }}$. fase. Nesse sentido, os próprios termos por ele escolhidos sugerem algum encaminhamento. O prefixo 'pós' nas fases segunda e quarta, consecutivamente referindo-se à superação da tonalidade e da modernidade, merecem atenção. Quanto à tonalidade e sua superação, em Almeida Prado parece ser uma empreitada óbvia, no entanto o termo da quarta fase que liga ao conceito 'pós-moderno' 1 necessita de uma mínima contextualização para as considerações aqui desenvolvidas e constadas em notas de rodapé deste texto.

Como professor de Composição na UNICAMP, somando-se ao fato de ser um compositor produtivo, as entrevistas realizadas pelos pesquisadores de suas obras, estabeleceram-se como oportunidades e consequentes provocações que o estimularam a um processo de aprofundamentos e teorizações que ele fez de si próprio, deixando um legado filosóficopoético de sua composição. Aponto algumas de suas declarações que ajudam a construir esse conjunto teórico-composicional:

\section{Declaração 1}

"O meu discurso como compositor não é tonal como Beethoven e nem serial como Schoenberg. Eu sou uma fusão disso." [...] "Eu trabalho com mecanismos intervalares para substituir o tonal e o atonal." [...] "Estou em nome de uma expressividade intervalar [...]" (PRADO e NADAl, 2007, p. 117).

\section{Declaração 2}

"Para exemplificar o que seria essa permutação, imagine uma mesa com objetos colocados de diversas maneiras, e esses mesmos objetos sendo colocados de maneira diferente nesta mesma mesa. Você permutou os objetos. Eu fiz isso, mudei a ordem dos compassos. Uma colagem como fazia Picasso, arte contemporânea, como mudar o verbo para fazer uma mistura, algo que não era permitido na época de Beethoven, e o resultado soa muito bem. O processo de permutação pode também ser comparado à mudança de objetos dentro de uma casa. A casa não muda, o tamanho dos cômodos não muda, o que acontece é um reposicionamento dos objetos." (PRADO e NADAI, 2007, p.114).

\section{Declaração 3}

“E. P. - O senhor acredita que estejamos esgotados de caminhos e ideias?

A.P. - Não, não acredito. Nunca se esgota. Sempre haverá um olhar novo sobre a mesma coisa. O problema é o olhar novo sobre o mesmo objeto. Por exemplo: se você colocar uma cesta de frutas numa sala e abrir esta sala para Picasso, Matisse, Monet, Manet, Di Cavalcanti, Portinari, cada um vai pintar a natureza morta à sua maneira. As mesmas maçãs, peras, uvas... O objeto é o mesmo; o olhar sobre é que é diferente. 0 compositor pode ter uma fase de cansaço, de esgotamento, onde não tem mais o que dizer, nem no tonal, nem no atonal... É uma fase [...]" (PRADO e PIRES, 2007, p. 78).

\section{Declaração 4}

"[...] Almeida Prado é aquela pessoa que quer ficar com um pé no Guarnieri e um pé em Schoenberg. É isso que eu quero, essa síntese, eu não quero 'ou' eu quero 'e'. Desde aquela época eu era 'e' e não 'ou', branco ou preto, não, 'preto e branco' e 'vermelho e amarelo' e de tudo eu faço uma grande sopa. Essa foi sempre a minha ideia do que seria música compreensível para o público. Com isso eu fui deixando na minha obra elementos do Camargo Guarnieri, que eu nunca abandonei. Por que eu 

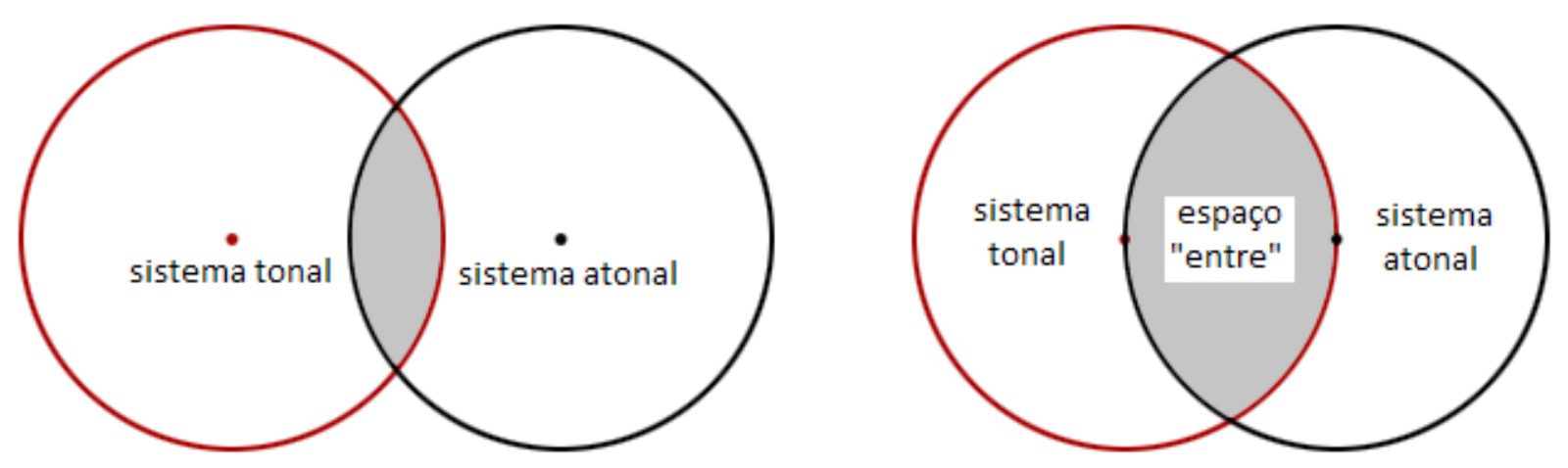

Figura 1 - Espaço "entre": um lugar entre o sistema tonal e o sistema atonal.

vou deixar uma coisa que é boa? Porque agora eu sou atonal? Eu posso ser o pós-moderno de tudo abarcar, é o que fez Stravinsky, que é o compositor mais completo do século $X X$, porque ele abarcou tudo." (ACADEMIA BRASILEIRA DE M:SICA e PRADO, 2001, p. 10).

Quadro 1 - Almeida Prado: considerações sobre sua produção musical.

"Almeida Prado, parte de uma relação básica com o sistema tonal. Ele funciona como um alicerce, como pavimentação de fundamentos baseados nos modelos, regras e rudimentos da harmonia, das funções harmônicas pensadas como em Riemann" (O AUTOR, 2009c, p. 29). O interesse do compositor aqui é subverter e re-processar os conceitos tonais e formais (O AUTOR, 2013). Uma "formulação que prevê uma re-interpretação de todo complexo de notas (alturas individuais), intervalos e estruturas acórdicas. Estas estruturas modelares estão numa ordem vertical ou horizontal e vinculados primariamente ao sistema tonal" (O AUTOR, 2009c, p. 29). Os desvios e quebras das regras do sistema tonal na composição de Almeida Prado se configuram como aproximações e distanciamentos desse sistema em direção a outros espaços. De uma certa forma, Almeida Prado parece perceber esse espaço, e trata de operar com seu atonalismo livre, passeando entre tonalismo e atonalismo, às vezes convertendo-se em um serialismo livre.

As gradações existentes entre o tonalismo e o atonalismo oferecem um terreno hábil e amplo para a construção e organização dos materiais. A exploração da direção e inversão dessa direção, que se converte em ato compositivo de gradações do atonal ao tonal e vice versa.

No sentido poético, o compositor tem uma intenção de apresentar os materiais sob aspectos de contraste, ambiguidade e dubiedade. Almeida Prado ao teorizar sobre si mesmo diz que, ele é "[...] aquela pessoa que quer ficar com um pé no Guarnieri e um pé em Schoenberg. É isso que eu quero, essa síntese, eu não quero 'ou' eu quero 'e'". O próprio compositor postula "sobre o terreno sistêmico que pretende fixar-se, se bem que tal postura, como ele próprio diz, não o impede de transitar entre o tonal e o atonal. Sua revisitação ao tonal se dá em outra ordem de construção pós-moderna" (O AUTOR, 2009c, p. 30). Nesse mesmo espaço sistêmico ampliado, há uma outra estratégia que entra como uma espécie de retratamento no posicionamento da altura musical no princípio da série harmônica, inserindo "o uso racional dos Harmônicos Superiores ${ }^{2}$ e Inferiores ${ }^{3}$ , criando Zonas de Percepção da Ressonância" (PRADO, 1985, p.559). Essa estratégia é mais, ou menos intensificada em determinadas composições e suas fases composicionais (PósTonal, Síntese e Pós-Moderna). Algumas vezes também é chamada por Almeida Prado de um "sistema musical", onde nele ocorre uma "tentativa de colocar juntos as experiências atonais com o uso racional dos Harmônicos Superiores e Inferiores". Esse sistema é denominado por ele como transtonalismo ${ }^{4}$. O compositor diz que o transtonalismo não é um 'sistema' para que outros possam imitar - como o 'sistema serial' de 

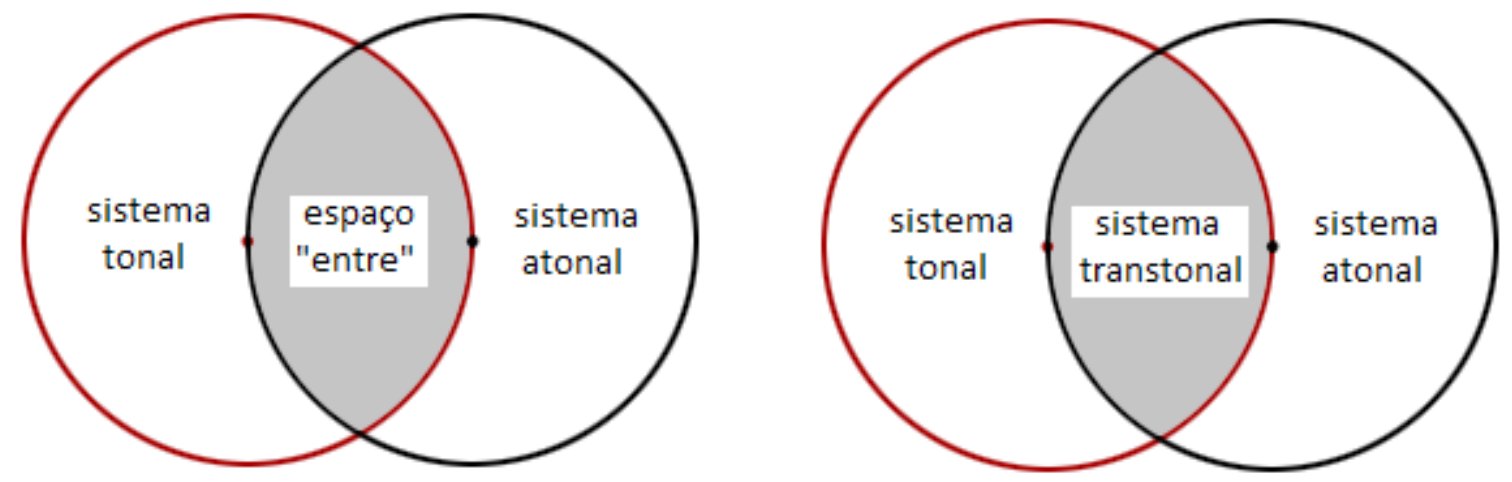

Figura 2 - Segundo Almeida Prado (1985), o espaço "entre" é o sistema transtonal.

Schoenberg. Para ele, não existe uma normativa ortodoxa, mas sim possibilidades livres.

Sua composição invariavelmente continua utilizando estruturas de origens dos dois sistemas (tonal e atonal), e virão restabelecidas e fundidas neste 'outro sistema', mas tais estruturas, na fase PósModerna têm mais intensificadas esse cunho de grande liberdade, a qual ele, o compositor, chamou essa 'liberdade postural' de "ecletismo total". "Em minha tese, tentei racionalizar um pouco. 0 transtonal refere-se a uma mistura de serial, com atonal, e com tonal" (PRADO e MOREIRA, 2002, p 63). O conceito transtonal aplica-se também à utilização de notas que pertençam às ressonâncias da nota fundamental de um acorde (ex. como o acorde de Messiaen, ou outra estrutura acórdica).

\section{SUPERAÇÃO DO TERMO EXPRESSIVIDADE INTERVALAR EM DIREÇÃO AO INTERVALO CARACTERÍSTICO}

Após o processo da análise musical dos Dezesseis Poesilúdios (pesquisa de mestrado) e da Sonata $n^{\circ} 3$ (fase Pós-Tonal), as Cartas Celestes I (fase Síntese) e o Noturno n. ${ }^{\circ} 7$ (fase Pós-Moderna) [pesquisa de doutorado], é possível dizer que as verificações e os dados obtidos dessas análises oferecem uma direção plausível para afirmar a existência de uma lógica e um controle intervalar em Almeida Prado. Existe uma referência organizada das distâncias, uma consciência clara de que sua composição é alimentada pelo cuidado às mínimas constituições do parâmetro da altura no total cromático: os intervalos em seus sistemas e seus desvios intencionais.

Como parte do exercício metodológico deste trabalho, é importante relembrar nossas questões de pesquisa, recolocando-se uma das indagações principais que envolve a busca da compreensão da concepção intervalar como material organizado, consistente e recorrente, nas bases de uma definição dos termos. Seria coerente, e não contraditório em bases epistemológicas, o termo expressividade intervalar? Haveria necessidade de se construir ou substituir uma classificação/nomeação de um termo que abarque a concepção, a importância e a modelagem intervalar que são apontadas no processo analítico das obras de Almeida Prado?

O termo expressividade intervalar, forjado em primeira mão pelo compositor, foi ampliado e organizado em pesquisa anterior (O AUTOR, 2009c), como conceito explícito acionado e ordenado pelas preferências de certas distâncias entre as alturas (diacrônicas, sincrônicas e diagonais) em sua estruturação harmônica.

A expressividade intervalar perpassa vários sistemas musicais - tonal, modal, atonal, serialismo livre e transtonalismo - tal vinculação ocorre por uma ordem de organizações intervalares, que fazem tais intervalos estar dentro de um sistema ou outro, ou na intersecção ou margem dos mesmos sistemas. Portanto essa ordem de padrões e recursividade define-se como a expressividade intervalar com sentido ampliado e desenvolvido a partir do termo cunhado pelo próprio compositor ( $O$ AUTOR, 2009c, p 14).

“No total cromático, o intervalo mínimo é o intervalo de segunda menor. Os intervalos são classificados pela quantidade de semitons existentes entre uma altura e outra" (O AUTOR, 2009c, p. 45). Cada tipo de intervalo possui capacidades qualitativas 
sonoras que indicam maior ou menor "nível de tensão" (Persichetti, 1961, p. 11-20). Nesse sentido, pretendi aproximar as conceituações de Costére (polaridade) às de Forte, Lester e Straus (pitch class), no entanto, devo apontar que não aprofundo os conceitos da Set Theory para os procedimentos teórico-analíticos que empreendo nesta pesquisa. Na minha formulação só me refiro à classe de intervalos de Forte como um conceito tangente às definições de "polaridade" de Costère (1954, 1962) e "dissonâncias duras" mencionadas em Persichetti (1961).

Relacionei vários pontos da construção argumentativa sobre a questão intervalar construída na pesquisa anterior (2009). Os excertos abaixo apresentam os argumentos dizendo que

1. [...] o intervalo deve ser considerado como modo de organização entre dois pontos sonoros, assim devem ser contemplados como unidades elementares das relações dentro das estruturas acórdicas e sistemas musicais, ressalvando que a disposição de direção dos materiais deve sempre ser observada na lógica da verticalidade como na da horizontalidade (O AUTOR, 2009c, p. 46).

2. O quadro de possibilidades de utilização intervalar envolve três intervalos. 0 primeiro deles considerado não somente a menor medida dos sistemas musicais baseados nos Doze Tons, mas de fato a segunda menor, torna-se o intervalo conceitual do compositor. Descendente do intervalo de segunda menor, os outros intervalos, o de sétima maior e o de nona menor fecham o quadro de relacionamento da segunda menor. 0 compositor toma estes intervalos e os coloca em projeção de valorização através da recorrência dos mesmos. A sistematização da música atonal pela "classe de alturas" de Forte e Straus colocam como categoria 1 os intervalos de segunda menor, sétima maior e nona menor. A categorização de Forte e Straus coincide com a eleição dos mesmos intervalos por Almeida Prado nos Poesilúdios. Assim, Almeida Prado, apesar de conseguir por métodos ideológicos diferentes, tais intervalos ( $2^{\mathrm{a}}$. menor e seus correlativos), os reconhece e atribuiIhes valor e importância de tensão máxima, ou o intervalo básico de maior tensão - a segunda menor [Persichetti, 1961, p.13] (O AUTOR, 2009c, p. 49).

3. [...] uma ocorrência de intervalos de segundas - tantos maiores como menores. É importante salientar que a compreensão de intervalo se estende tanto a aspecto vertical (intervalo harmônico) e horizontal (intervalo melódico, e ou saltos dentro de uma lógica arpejada de um dado acorde). Observase uma predominância do intervalo de $2^{a}$. menor e de seus correlativos ( $7^{\mathrm{a}}$. maior $-8^{\mathrm{a}}$. diminuta; $8^{\mathrm{a}}$. aumentada - $9^{a}$. menor). Ainda que todos tenham recorrência equiparada, o intervalo de $2^{a}$. menor emerge como o extrato desta classe de quatro intervalos. O intervalo de $2^{a}$. menor é a 'menor medida' na gama de sistemas que utilizam os Doze Tons. A espécie sonora gerada por esse intervalo é explorada nos planos verticais e horizontais; arrumados em nota contra nota que ao gerar o intervalo de segunda (menor) quer-se expandir o conceito de sobreposições e contraste por essa ocorrência intervalar.

4. Abaixo é demonstrado um breve quadro de entendimento de equiparação dos intervalos $2^{\mathrm{a}} . \mathrm{m}$, $7^{\text {a }}$. M e 9. ${ }^{\text {a }}$. O quadro ajuda no entendimento dessa equiparação e na construção do pensamento de atribuição de valor e importância desses intervalos no processo de estabelecer a malha que dá unidade aos Dezesseis Poesilúdios.

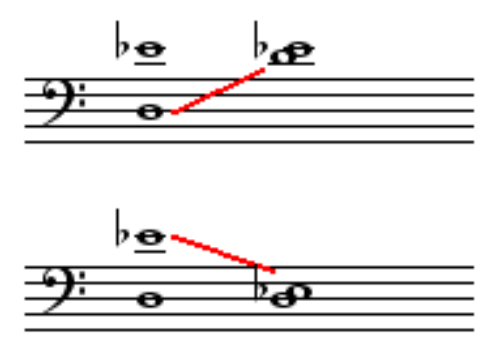

Figura 5 - 9a menor e sua equivalência com a $2^{\mathrm{a}}$. menor

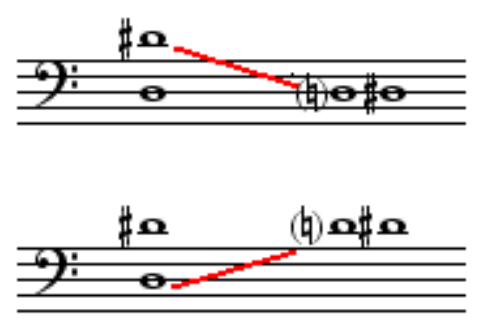

Figura $6-8^{a}$. aumentada e sua equivalência com a $2^{\mathrm{a}}$. menor. 


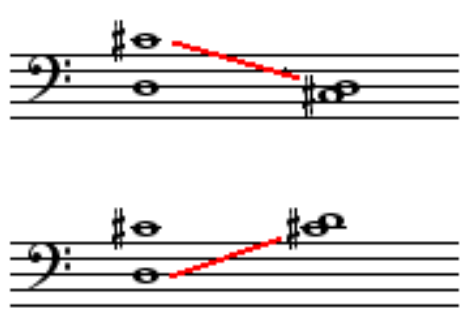

Figura $7-7^{\mathrm{a}}$. maior e sua equivalência com a $2^{\mathrm{a}}$. menor.

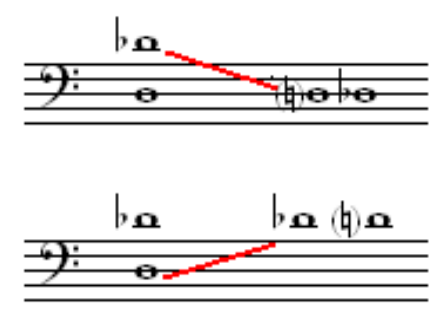

Figura 8 - $8^{\mathrm{a}}$. diminuta e sua equivalência com a $2^{\mathrm{a}}$. menor.

Os intervalos de $2^{\mathrm{a}}$. menor e seus correlativos (7 $7^{\text {a }}$ maior, $8^{\text {a }}$. diminuta, $8^{a}$. aumentada e o de $9^{a}$. menor) têm função de estabelecer a unidade da composição. A ocorrência intervalar sugere que a repetição de determinados intervalos, como os apontados acima, esteja em disposição horizontal ou vertical, vai além de um dispositivo ocasional, mas se configura como um elemento condutor que unifica e concede uma ampla gama de timbres $(0$ AUTOR, 2009c, p. 51).

Reforçando a percepção de Almeida Prado quanto ao valor e potência de tais intervalos, o relato de Flo Menezes (2002) a respeito do intervalo de segunda menor delineia suas características fenomenológicas nos processos harmônicos da música nova no repertório composicional do século XX e XXI:

A emancipação das Segundas menores do plano sequencial para o plano simultâneo fez com que um fator de proximidade melódica, essencialmente horizontal, fosse trazido para a verticalidade, perdendo, nesse processo, seu claro direcionamento melódico "sensível", de proximidade. Ao se perder a sensibilização melódica, ganha-se aí, em contrapartida, um equilíbrio ou estabilidade ambígua, bipolar, entre os dois componentes do intervalo. A "dualidade de poder" presente na instabilidade de qualquer intervalo apolar de maneira antagônica comporta-se, aqui, como estável, equilibrada, exercendo um apoio acústico recíproco. Através da simultaneidade de ambos os componentes de uma Segunda menor, tem-se, pois a quebra de polarização única em face da dupla sensibilização simultânea presente no intervalo (em mais um processo típico de pantonalidade), pois que um som não mais se direciona melodicamente ao outro. Qual das duas frequências de uma nona menor, sétima maior ou segunda menor (e seus maiores desdobramentos pelas oitavas) se sobressai, se polariza, quando ambos os sons componentes do intervalo soam simultaneamente? Tal questão poderá encontrar resolução somente mediante os outros tantos fatores do contexto musical, entre os quais a presença de outras frequências que determinem a polaridade do aglomerado sonoro determinado, tendendo mais para uma nota do que para outra desses intervalos cromáticos verticalizados (MENEZES, 2002, p. 114).

Almeida Prado que se autodefinia como "[...] um compositor muito tímbrico" (PRADO e MOREIRA, 2004, p. 76) pôde vincular sua produção composicional a um dos aspectos do seu transtonalismo: obtenção variada do timbre por meio do controle intervalar. Assim, novamente se referindo a sistemas, ele diz que "[...] refere-se a uma mistura de serial, com atonal, com tonal. É o uso livre das ressonâncias, com alguns harmônicos usados de maneira consciente [...]" (PRADO e MOREIRA, 2004, p. 75).

Ao certo é que se é ou não plausível continuar a adotando o termo expressividade intervalarou este atual, abarcando sua concepção intervalar como intervalo(s) característico(s), a questão desse e outros arquétipos intervalares, em Almeida Prado, é comprovada e determinante. Ela pode ser reforçada teoricamente por vários conceitos-analíticos evidenciados por autores já citados, como: os intervalos polares (Costère, 1954, 1963) e a classe 1 de intervalos do pitch class (Forte, 1973) (Lester, 1989) (Straus, [1990] [2000] 2013). Ainda sim, podendo se acrescentar o conceito da harmonia de simultaneidade de Pousseur (POUSSEUR, [2005] 2009), (MENEZES, 2002, 2009).

O uso do(s) intervalo(s) característico(s) é um processo altamente efetivo que produz na construção da estrutura composicional de Almeida 
Prado uma malha condutora que cumpre um caráter orgânico. Essa concepção intervalar tanto materializa a base de uma estrutura condutora de organicidade como abre caminhos com grande índice de inovação e possibilidades tímbricas. Nesse sentido, das possibilidades, o âmbito alargado de multiplicidades se conforma no gesto poético que se apropria de novas contemplações sonoras como em semelhança de um pintor que vai materializando suas ideias, enveredando por visões inesperadas, planejamentos e moldagens inéditas nos conjuntos e expressões cor-som. Tal conjectura teórica é passível de ser aplicada nesse terreno novo, virginal e inesgotável das combinações intervalares de segunda menor, sétima maior e nona menor, somadas às outras possibilidades intervalares oriundas das estruturas acórdicas mais ou menos pertencentes a outros sistemas musicais. Inclusive, Pousseur fala de uma força atrativa dos referidos intervalos ( $2^{\mathrm{a}} . \mathrm{m}, 7^{\mathrm{a}}$. M e 9a. $\mathrm{m}$ ), em conjunto com a questão primária de dissonância que propicia a eles as "zonas de contato" ([2005] 2009, p. 58), estas fortalecidas, tornando tais intervalos em redutos de energia sonora que tangenciam/contrastam os outros intervalos inicialmente primordiais da série

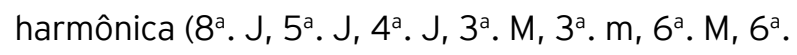
$\mathrm{m}$ e trítono). Em síntese, Almeida Prado se apropria dessa possibilidade de "zonas de contato" entre o(s) intervalo(s) característico(s) e os outros intervalos (iniciais da série harmônica), que são geralmente um pano de fundo que representa o pavimento tonal que é contrastado com os intervalos de "dissonância dura". Assim, tanto o(s) intervalo(s) característico(s) como os intervalos iniciais da série harmônica (e todos os outros seus derivados mais tangentes ao sistema tonal) convertem-se entre si próprios como estruturas-camadas sempre dispostas sob uma forte configuração de fricção intervalar com grandes possibilidades tímbricas.

Em síntese, como referência teórica-musicológica à importância ao problema do intervalo, se pode apontar a partir do que Massimiliano Locanto (2009) disse em seu texto 'Composition with Intervals': Intervall Syntax and Serial Techinique in Late Stravinsk: "Embora todos estes compositores tratem o componente intervalar de maneiras diferentes, tornou-se para eles o aspecto fundamental de uma técnica motívica - isto é, uma utilização com base em um número restrito de figurações intervalares que servem a uma função unificadora dentro de uma obra musical" (LOCANTO, 2009, p. 221, grifo nosso). Sabendo-se que Lacanto falasse do próprio Stravinsk, incluindo Schoenberg e seus alunos Webern e Berg, ainda assim, podemos inserir com uma afirmação segura que a produção pós-ruptura de Almeida Prado está atrelada fortemente ao pensamento de (re)estruturação intervalar.

\section{SONATA N. ${ }^{\circ}$ 3: ANÁLISE INTERVALAR}

\section{Intervalo característico em ostinato (I mov.: c. 3-7)}

A segunda menor em estado sincrônico segue com a proposta de um ostinato - uma ideia de camada. Almeida Prado tem uma predileção por essa arrumação, construindo camadas, como estratificações ${ }^{6}$ de materiais, ampliando a ideia e manutenção das sobreposições, pois elas podem alimentar, por contraste de materiais diferentes, desejavelmente a poética da ambiguidade - uma ambição persistente em Almeida Prado.

Essa camada, como um acompanhamento para o material melódico, é estabelecida pela repetição ostensiva do intervalo de segunda menor em uma mesma altura.
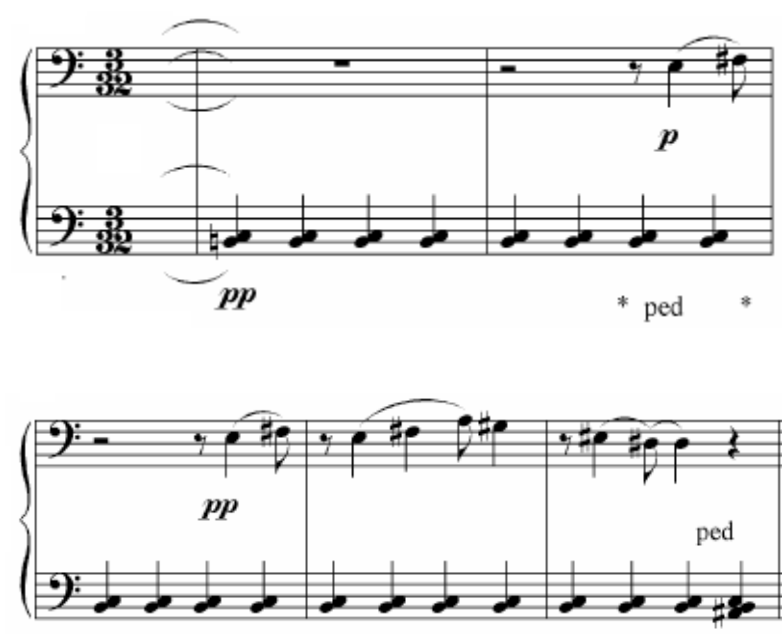

Figura 3 - Intervalo característico aplicado com ideia de camada-acompanhamento para o material melódico.

\section{Intervalos de segundas por acumulação (I mov.: c. 7-8; II mov.: c. 33-34)}

Ao final do trecho acima, Almeida Prado, utiliza-se de uma acumulação intervalar por segunda menor. A partir da referência anterior, o ostinato que agrega sincronicamente o Si1 e o Do2, ocorre um 
empilhamento que vai desse intervalo de segunda menor ao esquema cumulativo em direção à tessitura mais grave. Uma técnica de empilhamento invertido em direção ao grave. O intervalo de segunda menor vai sendo vez após vez adicionado, deixando a estrutura acórdica em novidade constante. Um processo cumulativo de intervalos, uma ideia somatória.

Nessa construção por empilhamento intervalar, faz-se rapidamente ocorrer uma transição de uma estrutura acórdica qualquer para uma estrutura em cluster.

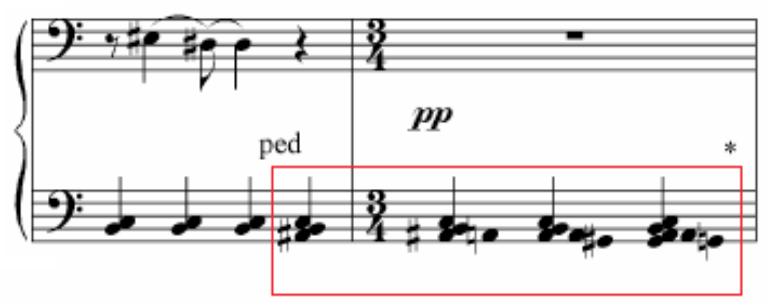

Figura 4 - Segundas menores por processo cumulativo: uso dos materiais por intervalo característico.

Nos compassos 33 e 34 do I Movimento, a construção por acumulação intervalar ocorre de uma maneira mais ampliada.

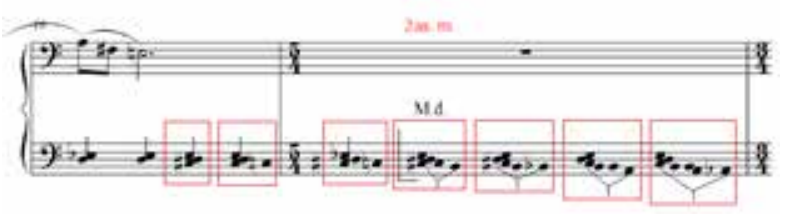

Figura 5 - Segundas menores por acumulação.

\section{Tematização por tipo de intervalo característico (I mov.: c. 9-10)}

Intencionalmente o compositor estabelece uma tematização 8 intervalar fazendo uma repetição insistente da segunda menor. A manutenção da ocorrência intensiva do intervalo é mantida desde o primeiro movimento da peça. Já em terreno do segundo movimento, o intervalo ainda continua sendo material composicional para o seguimento estrutural. Há de se observar que as correlações de direção, neste trecho, são unicamente de uma preocupação horizontal. Em certo sentido, uma ordem melódica, que poderia ser tocada com única mão (esquerda ou direita: como se queira), sendo uma espécie de pontuação da estrutura por um trinado. É interessante notar que a mesma pontuação serve ao papel de uma ponte que liga a próxima inflexão sonora. Note-se que a segunda menor segue com desenvoltura na operação, e comprovadamente a predominância do tipo intervalar é facilmente identificada no exemplo abaixo.

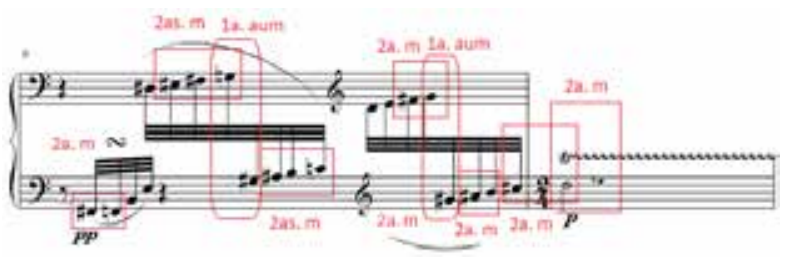

Figura 6 - Predominância de um (1) tipo intervalar: a segunda menor - por uma ordem direcional horizontal (tematização intervalar por segunda menor).

\section{Relações de direcionalidade diagonal (II mov.: c. 6-7)}

Menezes diz que (2013, p. 74): "A música pode então ser definida como direcionalidades conscientemente elaboradas". Em Almeida Prado, as direcionalidades ${ }^{9}$ são ordens de organização que interferem sensivelmente na estrutura harmônica. É provável que se exija mais cuidado para a compreensão e detecção da relação diagonal, pois em sua lógica construtiva pode haver uma maior complexidade. Geralmente as direcionalidades horizontais e verticais são mais prontamente observadas. Portanto, na diagonalidade podem residir sutilezas e relações mais inesperadas.

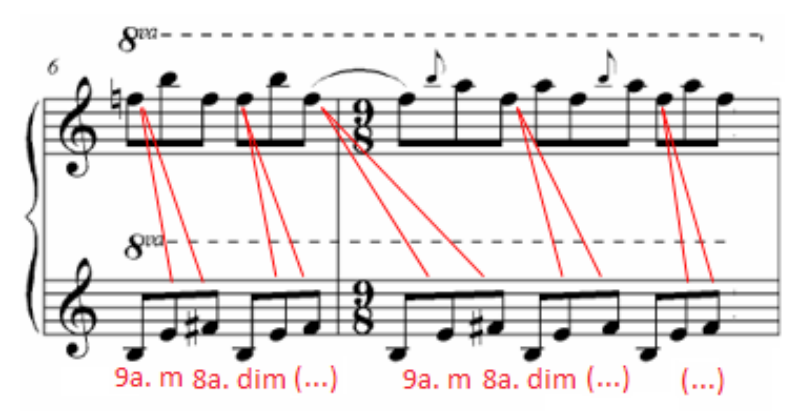

Figura 7 - Relação diagonal de intervalos característicos de $9^{a}$. $m$ e $8^{a}$. aum 


\section{Modelo motívico com segunda menor na cabeça da estrutura rítmica (II mov.: c. 71-73; c. 84)}

No trecho abaixo, parece haver uma similaridade rítmica-intervalar com o conceito da tematização intervalar. Como se vê há um modelo recorrente de um formato motívico por segunda menor. Este modelo carrega a padronização rítmica em conjunto com a já observada tematização intervalar (repetição do intervalo característico na primeira nota do conjunto das quatro semicolcheias).

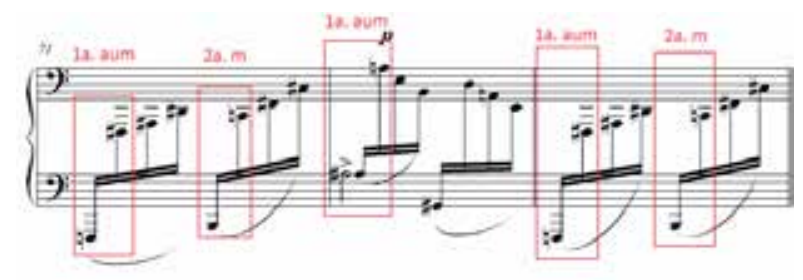

Figura 8 - Modelo intervalar-rítmico com base no intervalo característico de segunda menor (primeira aumentada).

Outro caso, no próximo exemplo, com o mesmo desenho estrutural na forma rítmica de 4 semicolcheias, uma esquematização onde 0 compositor coloca a nota mais grave como base para se estabelecer a relação de intervalo(s) característico(s) nas $2^{\text {as }}$. e $4^{\text {as }}$. semicolcheias: segunda menor e oitava diminuta. Notadamente, este é um outro caso de tematização intervalar com direção por diagonalidade. Na figura abaixo, a amostra do compasso 84 do II Movimento.

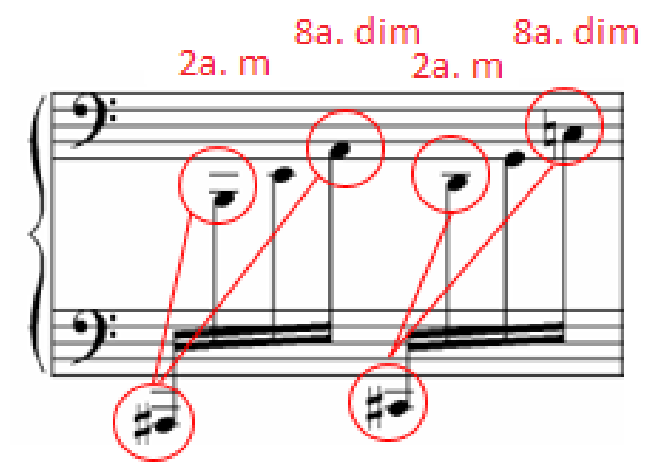

Figura 9 - Padronização da ocorrência do(s) intervalo(s) característico(s).

\section{Outro caso de relação intervalar por diagonalidade (II mov.: c. 74)}

Neste exemplo, há uma outra ocorrência de intervalos(s) característico(s) por diagonalidade e uma tematização intervalar. Entretanto, neste caso são usados dois tipos de intervalos - nona menor e segunda menor - contando com a enarmonia da nona menor para a oitava aumentada (ou vice versa), assim hipoteticamente contabiliza-se três tipos intervalares (somente dois sonoros). A enarmonia apesar de trazer uma dubiedade e sutileza, ainda assim fornece a possibilidade de se perceber com relativa atenção o intrínseco planejamento intervalar a partir do registro gráfico musical.

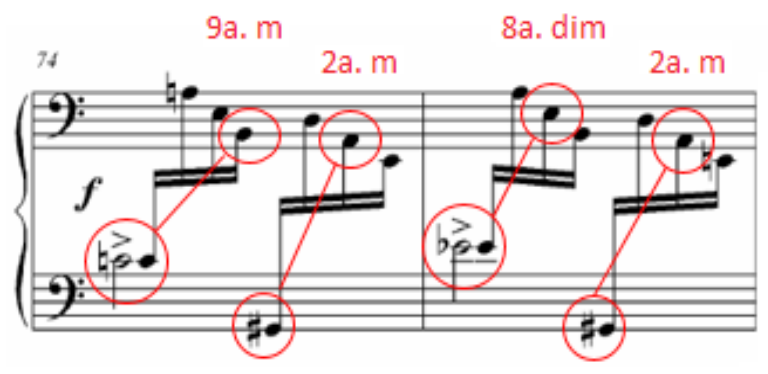

Figura 10 - A organização intervalar por diagonalidade.

\section{Padronização da ocorrência do intervalo característico dentro de um modelo rítmico (II mov.: c. 94)}

Almeida Prado busca uma expansão do trato intervalar, colocando o intervalo característico como elemento gerador de outras possíveis organizações recorrentes - um uso temático do material. Neste trecho em questão, em termos temporais, ocorre uma horizontalização da direção, em contrapartida pode ser pensado também como uma opção que parte do grave para o agudo, seguindo os pontos das alturas mais agudas ainda. Nessa demanda de relação ascendente que busca intercalar cada tercina (três colcheias na tercina: $1^{\mathrm{a}}$ figura da tercina: som grave; $2^{a}$. figura da tercina: som médio; e $3^{a}$. figura da tercina: som mais agudo) - verifica-se aí uma direcionalidade diagonal. São nas figuras extremas da tercina (grave: $1^{\text {a }}$. figura da tercina; e a aguda: $3^{a}$. figura da tercina) onde ocorrem a relação do intervalo característico. Observe-se o compasso 94 do II Movimento: 


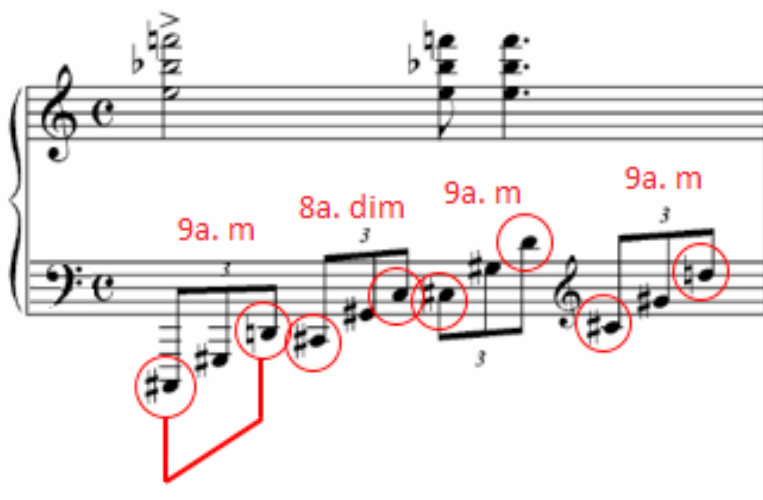

Figura 11 - Ocorrência do intervalo característico em modelo rítmico: a tercina.

\section{Sobreposição intervalar tematizada (II mov.: c. 134-136)}

A tematização ou padronização intervalar prossegue demonstrando possibilidades em um caso baseado na verticalidade intervalar, seguindo uma ideia de variar os materiais, um arranjo de soluções novas no desenvolvimento estrutural - o compositor propõe a sobreposição intervalar com algumas possibilidades dentro do eixo da oitava. Parece ser, nesta passagem, um esforço para algumas variantes da materialização da polaridade da oitava (COSTÈRE, 1954, 1962) (POUSSEUR [2005] 2009) (MENEZES, 2002). Ao certo, algumas variações são desenvolvidas a partir dessa distância intervalar básica: a oitava justa. Sendo assim, a sétima maior, como meio-tom menor que uma oitava justa, e, em direção contrária, a oitava aumentada como meio-tom maior que uma oitava justa - como estruturas conviventes em sobreposição (a oitava mais as dissonâncias duras [ $7^{\mathrm{a}} . \mathrm{M}, 9^{\mathrm{a}}$. m]) acentuam a estruturação intervalar por fricção e contraste. Esse modelo estrutural intervalar é baseado nessa formação vertical que explora as possibilidades na cercania da oitava justa: acrescentando aos intervalos sobrepostos, obviamente o intervalo de segunda menor.

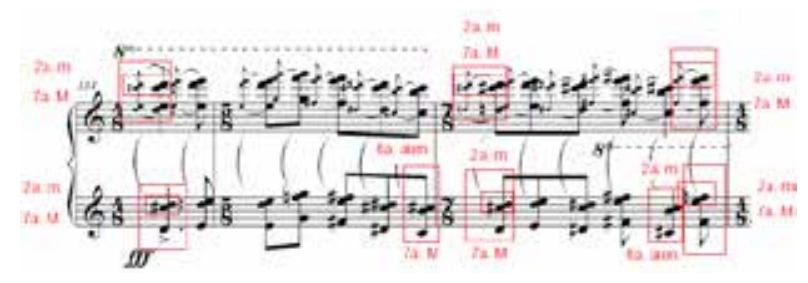

Figura 12 - A variação do intervalo característico a partir da oitava justa em direcionalidade vertical.

\section{Intervalos ascendentes de segundas menores: com sobreposição de quartas justas (II mov.: c. 147-150)}

Esse exemplo, trata-se de uma intensificação das segundas menores com outras possibilidades combinatórias de intervalos. Em termos poéticos, o compositor continua o conceito de tematização intervalar. Observe-se que no compasso 150, ocorrem as sobreposições quartais que se estenderão a posteriori nos compassos 151 ao 154. O exemplo abaixo enfatiza os compassos 147 ao 150:

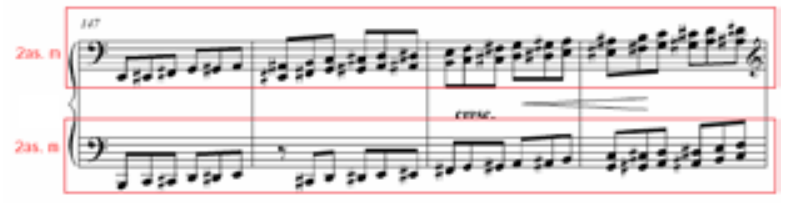

Figura 13 - Sobreposição quartais por uma ordem de ligação em horizontalidade de segundas menores.

\section{Relação espelhada de segundas menores (II mov.: c. 172-173)}

Uma combinação intervalar ainda não ocorrida nesta obra. Por um tratamento espelhado das segundas menores, sendo esse procedimento, uma espécie de alusão semantizada ao serialismo. Em alguns aspectos, por essa ordem de reutilização e transformação de sentidos, Almeida Prado oferece a possibilidade da lembrança e correlação signicativa da poética das pluralidades e não ortodoxia serial de Berg.

Entretanto, o serialismo de Almeida Prado é anunciadamente livre. A própria menção do espelhamento, mesmo que de forma transformada e semantizada, torna-se uma concepção continuada a partir do sistema serial. Entendendo que a forma retrógrada (RO) e forma inversa do original (IO) no serialismo dodecafônico, são ideias pertencentes à organização direcional por espelhamento, ainda assim convém lembrar que o procedimento espelhado é largamente utilizado já no período Barroco, especialmente com J. S. Bach.

Sob os dados teórico-históricos e as informações autobiográficas que o compositor fez sobre sua formação no campo tonal, e agora se deparando com subsídios que também foram utilizados em música atonal e serial, é perfeitamente plausível 
compreender tais artifícios que declaradamente fazem com que Almeida Prado transite entre o tonal e o atonal, sob o fato de tal compreensão, ser ajustada à perspectiva e aos propósitos do espaço "entre" sistemas (seu transtonalismo).

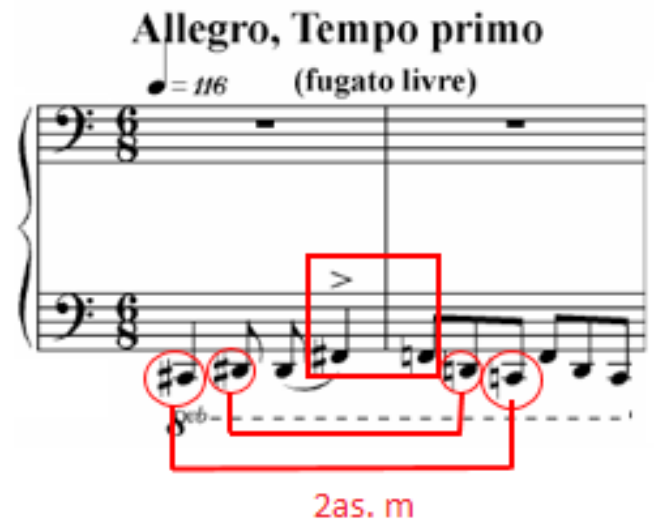

Figura 14 - Espelhamento de relações pelo intervalo característico de segunda menor.

\section{CONCLUSÃO}

Através dos excertos analisados na seção anterior, ficou demonstrado que Almeida Prado, em seu ato compositivo, faz com que o intervalo transforme-se em um conteúdo de primeira ordem, configurando-se como uma das bases substanciais de sua composição. Os tipos de organizações intervalares determinaram as tangências e/ou os distanciamentos dos sistemas musicais, criando um espaço "entre" nos diversos sistemas (modal, tonal, atonal, serial livre) dando um aprofundamento à sua transtonalidade.

O sistema da transtonalidade não seria somente acionado pelas regras do "sistema organizados de ressonâncias", mas seria entendido também como o fluxo da lógica intervalar de um sistema para outro. Nesse sentido, o intervalo e seus tipos, incluindo efetivamente o(s) intervalo(s) característico(s), seriam o elo de ligação para a formação de conglomerados acórdicos com grande gama de ação e variação dentro dos sistemas. Eles se conectam e se desconectam a serviço da afirmação ou não de um determinado sistema. A meta teórica e composicional de Almeida Prado é a exclusão de limites ou faixas divisoras entre os sistemas. Pelo contrário, seu alvo poético é fundir os próprios sistemas em espaços mutáveis e amplificados. Não há obrigatoriedade de definição aplicável a partir de um certo sistema musical, os materiais são potencialmente vinculados aos vários sistemas por meio da concepção intervalar sob uma organização de materiais em camadas, em alongamentos, em encurtamentos, em deformações, em níveis, em possibilidades de novas aberturas na composição

\section{NOTAS}

1. O AUTOR, X. X. (nota acrescentada para este texto) "Para Villaça (1996, p. 28) o "[...] pós-moderno não é apenas depois do moderno, não é somente antimoderno, ou um nada póstudo. É momento de discussão, de multiplicidade de perspectivas sem queda no relativismo. É perda, é desagregação, mas também é aposta na multiplicidade". Quanto ao dizer quando começaria ou pudesse terminar a pós-modernidade, Sant'Anna (2003, p. 155) diz que "Em termos de datas, alguns se arriscam a dizer que a modernidade é algo que ocorreu na cultura ocidental entre 1860 e 1950 e que a pós-modernidade expressou-se a partir de 1950, tendo seu apogeu em torno de 1980. No entanto datas são discutíveis".

A pós-modernidade "exime-se da temporalidade histórica" e está ligada ao "presenteísmo", à "razão cínica, à "aparência", à "fragmentação", ao "pastiche", "deixando se levar pelo mercado" (SANT'ANNA, 2003, p. 155). É preciso dizer que Jean-François Lyotard (1924-1998) é sem contestação a figura mais marcante da filosofia da pós-modernidade, e para ele a pósmodernidade é um "movimento 'anti' posturas" (SHINN, 2008, p. 50). As multiplicidades e as rupturas, na pós-modernidade, parecem ocorrer combinadas em um só lugar. Kramer (1996, p. 22), musicalmente falando, anuncia as "fragmentações e as descontinuidades", o "pluralismo e o ecletismo", o que é "não linear" quanto aos conteúdos e suas aparições".

2. O AUTOR (2009c, p. 30-31) diz que "Como o conceito de "zonas de ressonância" é oriundo da série harmônica, já por si tal conceito é construído em bases da série harmônica e dos seus constitutivos - os harmônicos como base, uma ligação com próprio sistema tonal. Como Prado se propõe a trabalhar em um espaço entre o tonal e o atonal, ele necessariamente cria processos que tramitam entre as retóricas destes sistemas para ocupar tal espaço. Mas, tais retóricas que tramitam entre esses 
sistemas, estão de posse de uma grande liberdade. "Uma total ausência de ser coerente, um assumir o incoerente" (PRADO e MOREIRA, 2002, p. 58).

3. RAMIRES (1998, p. 270) diz que "Considerando entretanto a Série Harmônica Invertida e seu vínculo com o Modo Menor, Costère apoia-se na corrente dualística e principalmente nas ideias de Hugo Riemann (1849-1919), teórico dedicado ao desenvolvimento de um sistema harmônico baseado em suas pesquisas sobre a Série Harmônica Invertida (understones). Para Riemann "todos os possíveis acordes consonantes por dois sons de nomes diferentes correspondem a uma das duas classes de acordes: o 'acorde superior' que se chamava chamar de acorde maior, formado por uma terça maior e uma quinta justa superior, e o acorde inferior chamado de acorde menor, formado por uma terça (maior) inferior e quinta justa inferior".

4. O AUTOR (2009c, p. 32) acrescenta que: "Almeida Prado ressaltou o que Yulo Brandão disse de seu Dó maior "com ressonâncias" sendo o impulso para o seu transtonalismo que prevê a combinação dos materiais que vem da lógica de ressonância (PRADO e MOREIRA, 2002, p. 64). Observa-se que primariamente para se viabilizar o transtonalismo, a utilização do mecanismo do pedal de sustentação do piano é componente básico. O compositor associa o uso deste artifício técnico como um componente hábil de reforço da lógica do "sistema de ressonâncias"'".

5. "O transtonalismo como sistema de organização das alturas encontra um dos seus fundamentos no acorde de ressonância de Messiaen, que se baseia no emprego da série harmônica". [...] "Preferimos descrever o transtonalismo como um sistema predominantemente atonal de organização acrônica das alturas, que absorve e amplia o princípio do baixo fundamental herdado de Rameau [GUBERNIKOFF 1999], e as relações baseadas na série harmônica, incluindo, sem restrição, as construções forjadas a partir dos primeiros harmônicos - os que formam as tríades perfeitas" (GUIGUE \& PINHEIRO, 2001, p. 4).

6. CORRÊA (2014, p. 156) “Esse termoénormalmente entendidocomoasobreposição de planosoucamadas, tendo surgido na geologia, para designar a estrutura originada pela acumulação progressiva de qualquer material inorgânico (rochosos, minerais, vulcânicos, arenosos, cristalinos, causado por preciptação química ou decantação, entre outros) tendendo a formar camadas definidas por descontinuidades físicas e/ou por passagens bruscas ou transicionais de mudanças de textura, estrutura ou quimismo. [;] As ciências sociais importaram o termo para designar diferentes classes sociais de determinadas culturas, ou meios socioeconômicos, fato comprovado na vasta literatura sobre estratificação social. Mas Cone refere-se ao termo como justaposição no tempo de blocos musicais. A condição para a identificação desses blocos é o corte, já que os blocos normalmente são introduzidos de forma abrupta".

7. TATIT (1997, p. 97) “Não há tematização sem desdobramento, não há refrão sem segunda parte e não há gradação de alturas sem a intervenção dos saltos intervalares".

8. Tematização entedida como repetição, como padrão, como organização reiterada, como algum tipo de norma ou alguma razão.

9. MENEZES (2013, p. 41-2). [...] É na harmonia, em seu mais amplo sentido - relações entre notas ou frequências em dado contexto, que podem ocorrer sincronicamente (no plano vertical), diacronicamente (no plano horizontal), ou em ambos os estados (no plano diagonal, ou seja, em ambos os planos simultaneamente) - que agrupamentos de elementos instituem os mais diversos significados [...]".

\section{REFERÊNCIAS}

ALBRECHT, Cíntia Costa Macedo. Um Estudo Analítico das Sonatinas para Piano Solo de Almeida Prado, Visando a Sua Performance. Tese de Doutorado. Universidade Estadual de Campinas, Instituto de Artes, Departamento de Música, Campinas, 2006.

ASSIS, Ana Cláudia de. 0 Timbre em Ilhas e Savanas de Almeida Prado: uma contribuição às Práticas Interpretativas. Dissertação (Mestrado em Música). Universidade do Rio de Janeiro, Rio de Janeiro, 1997.

CORRÊA, Antenor Ferreira. Análise musical como princípio composicional. Brasília: Editora Universidade de Brasília, 2014.

DOURADO, Henrique Autran. Dicionário de termos e expressões da música. São Paulo: Ed. 34, 2004.

GOMES FILHO, Tarcísio. A prática intertextual em peças para piano de Almeida Prado: elementos 
de análise para construção da performance. Tese (Doutorado em Música). Universidade Estadual de Campinas, Campinas, 2010.

GROSSO, Hideraldo Luiz. Os Prelúdios de Almeida Prado - Fundamentos para uma Interpretação. Dissertação (Mestrado em Música). Universidade Federal do Rio Grande do Sul, Porto Alegre, 1997.

GUBERNIKOFF, Carole. A Missa de São Nicolau, de Almeida Prado, na confluência das opções estéticas dos anos 80. Revista Música, v. 9 e 10, p. 183209, São Paulo: USP-ECA, 1998-1999.

GUIGUE, Didier; PINHEIRO, Fabíola de Oliveira Fernandes. Dos Momentos e do Tempo estratégias de articulação formal nos Momentos de Almeida Prado. Universidade Federal da Paraíba. Paraíba, 18p. Disponível na World Wide Web: <http://www.cchla.ufpb.br/gmt/hp/pags_ pessoais/didier/DGDownloads/DGAP1.PDF>. Acessado em: 03 out. 2008.

LOCANTO, Massimiliano. 'Composition with Intervals': Intervallic Syntax and Serial Techinique in Late Stravinsk. In: Music Analysis, v. 28, n.) 2-3, p. 221-266, 2009.

MENEZES, Flo. Apoteose de Schoenberg: Tratado sobre as Entidades Harmônicas. 2a. ed. rev. e ampl. Cotia-SP: Ateliê, 2002a.

MOREIRA, Adriana Lopes da Cunha. A Poética nos 16 Poesilúdios para piano de Almeida Prado. Dissertação (Mestrado em Música). Universidade Estadual de Campinas, Instituto de Artes, Departamento de Música, Campinas, 2002.

. Flashes de Almeida Prado por ele mesmo. OPUS: Revista da Associação Nacional de Pesquisa e Pós-Graduação em Música - ANPPOM - Ano 10, n.) 10, dez. 2004, p. 73-80. Campinas, 2004.

NADAI, Robson Alexandre de. Sonata para Trombone e Piano de Almeida Prado: uma análise interpretativa. Dissertação de Mestrado. Universidade Estadual de Campinas, Instituto de Artes, Departamento de Música, Campinas, 2007.

NEVES, José Maria. Música Contemporânea Brasileira. São Paulo: Ricordi Brasileira, 1984.

PERSICHETTI, Vincent. Armonia del Siglo $\mathbf{X X}$. Tradución: Alicia Santos Santos, Antonio Barrera
Maraver e Antonio Ramirez-Angel Sorrosal. Madrid: Real Musical, [1961] 1985.

PICCHI, Achille. Mario Metaprofessor de Andrade: estudo crítico sobre o "Ensaio sobre Música Brasileira". In: Sinfonia Plural. São Paulo: Ed. do Autor, 2012. p. 198-???

PIRES, Elaine Lopes de Oliveira. Um sopro de Clarineta no Brasil - Resgate de Crônica de Um dia de Verão Fantasia para Clarineta e Orquestra de Cordas Almeida Prado. Dissertação (Mestrado em Música). Universidade Estadual de Campinas, Campinas, 2006.

POUSSEUR, Henri. Apoteose de Rameau e outros ensaios. Trad. Flo Menezes e Mauricio Ayer. Seleção dos textos, prefácio e notas críticas: Flo Menezes. São Paulo: Editora UNESP, 2009.

PRADO, José Antônio Rezende de Almeida. Cartas Celestes - Uma Uranografia Sonora Geradora de Novos Sons. Tese de Doutorado. Universidade Estadual de Campinas, Instituto de Artes, Departamento de Música, Campinas, 1985.

PRADO, José Antonio Rezende de Almeida; ACADEMIA BRASILEIRA DE M:SICA. Encontros com Almeida Prado. Entrevista compilada por Valéria Peixoto. Rio de Janeiro: ABM, jun.- jul. 2001.

RAMIRES, Marisa. As bases da teoria de Edmond Costère. In: XI ENCONTRO NACIONAL DA ANPPOM, 11, 1998, Anais... Campinas: UNICAMP, 1998 p. 267-272.

ROCHA, Junia Canton. Decisões TécnicosMusicais e Interpretativas no Segundo Caderno de Poesilúdios para Piano de Almeida Prado. Dissertação (Mestrado em Música). Universidade Federal de Minas Gerais, Belo Horizonte, 2004.

O AUTOR, xxxxx xxxxxx. Sistemas Musicais em Almeida Prado: nas fases Síntese e Pós Moderna. III Encontro de Musicologia de Ribeirão Preto. Universidade de São Paulo, Ribeirão Preto: 2009a.

Expressividade intervalar nos Poesilúdios n.) 13 de Almeida Prado. XIX Congresso da ANPPOM. Instituto de Artes. Universidade Federal do Paraná, Instituto de Artes. Curitiba: DeArtes, 2009b.

Expressividade intervalar nos Poesilúdios de Almeida Prado. Dissertação 
(Mestrado em Música). Instituto de Artes, Programa de Pós-Graduação Música em Contexto, Universidade de Brasília, Brasília, 2009c.

Almeida Prado: aspectos contextuais relevantes para a ruptura e direcionamento poético nas outras suas fases subsequentes. Revista Música em Contexto. Programa de Pós-Graduação em Música da Universidade de Brasília, ano VI, v. n.) 1, p. 97-120. Brasília: UnB, 2012.

Poesilúdio n) 4 de Almeida Prado: dimensões de tempo e altura como ferramenta de subversão e ampliação do conceito de forma. Revista Brasileira de Música, Programa de Pós-Graduação em Música, Escola de Música da UFRJ, Rio de Janeiro, v. 26, n. 1, p. 151-172, jan.jun. 2013.

SANT'ANNA, Affonso Romano de. Paródia, Paráfrase \& Cia. São Paulo: Editora Ática, 1985.

\section{Desconstruir Duchamp: a}

arte na hora da revisão. Rio de Janeiro: Vieira \& Lent, 2003.

SCARDUELLI, Fábio. Khamailéon: fantasia para violão e orquestra de Almeida Prado. Tese (Doutorado em Música). Instituto de Artes. Universidade Estadual de Campinas, Campinas, 2009.

SHINN, Terry. Desencantamento da modernidade e da pós-modernidade: diferenciação, fragmentação e a matriz de entrelaçamento. Scientiae Studia. v. 6, n. 1, p. 43-81. São Paulo, 2008.

STRAUS, Joseph Nathan. Introduction to post tonal theory. 2( ed. Upper Saddle River: PrenticeHall, [1990] 2000.

TAFFARELlO, Tadeu Moraes. O percurso da intersecção Olivier Messiaen-Almeida Prado: Momentos, La Fauvette des Jardins e Cartas Celestes. Tese (Doutorado em Música). Universidade Estadual de Campinas, Instituto de Artes, Departamento de Música, Campinas, 2010.

TOFFOLO, Rael Bertarelli Gimenes. As redes harmônicas de Pousseur aplicadas à composição musical em tempo real. Tese (Doutorado em Música). Universidade Estadual Paulista Júlio de Mesquita Filho, Instituto de Artes, Programa de Pós Graduação em Música, São Paulo, 2014.
TATIT, Luiz. Musicando a semiótica: ensaios. São Paulo: Annablume, 1997.

VAZZOLER, Luciano Ferrara. Stravinsk neoclássico: uma análise dos procedimentos composicionais. Dissertação (Mestrado em Música). Universidade Estadual Paulista Júlio de Mesquita Filho, Instituto de Artes, Programa de Pós Graduação em Música, São Paulo, 2008.

VILLAÇA, Nízia. Paradoxos do pós-moderno. Rio de Janeiro: Editora UFRJ, 1996.

WHITE, John D. Comprehensive Musical Analysis. London: The Sacarecrow Press, Inc. 1994.

YANSEN, Carlos Alberto Silva. Almeida Prado: Estudos para Piano, aspectos TécnicoInterpretativos. Dissertação (Mestrado em Música). Universidade Estadual de Campinas, Instituto de Artes, Departamento de Música, Campinas, 2005.

\section{Concerto "Fribourgeois"} de Almeida Prado para piano e cordas: um estudo para a interpretação. Tese (Doutorado em Música). Universidade Estadual de Campinas, Campinas: 2010.

\section{SOBRE O AUTOR}

Edson Hansen Sant ' Ana. Professor na disciplina de Artes/Música no Instituto Federal de Educação, Ciência e Tecnologia de Mato Grosso (IFMT). Em 1986, estudou Composição com Sergio VasconcellosCorrêa (UNESP). Bacharel em Música - Composição, pela UNICAMP (1996), onde foi aluno de Almeida Prado, Raul do Valle e Damiano Cozzella. Mestre em Música (Análise) pela Universidade de Brasília (2007-2009). Pesquisador assistente (2008-2009) da RIPM (Retrospective Index to Music Periodicals). Desenvolve pesquisa sobre composição de Almeida Prado, com ênfase em Teoria, Análise e Musicologia. Desenvolve trabalhos e práticas convergentes à Educação Musical (ensino coletivo de instrumento), harmonia, arranjo e improvisação. Concluindo o doutorado em Música pela UNESP (São Paulo-SP). Membro da Associação Brasileira de Teoria e Análise Musical (TeMA) e editor-chefe do boletim desta associação ( TeMA informativo). Em reconhecimento às iniciativas desenvolvidas no campo da Música, em março de 2017 recebeu a distinção honorífica "Comenda Carlos Gomes" pela SBACE. 


\title{
O QUE É PERFORMANCE? \\ ENTRE CONTEXTO HISTÓRICO E DESIGNATIVOS DO TERMO
}

\author{
Natalie Mireya Mansur Ramirez \\ UFES-SC
}

\section{Resumo}

Este artigo pretende explorar questões relacionadas aos designativos do termo performance, levando em consideração a abrangência de campos do conhecimento que esta envolve através de autores nacionais e internacionais, bemcomo alguns exemplos históricos. $O$ intuito desta pesquisa não é traçar uma historiografia sobre a arte da performance, mas descrever alguns dados que ajudem na compreensão daquilo que buscamos entender como tal.

\section{Palavras-chave:}

performance, designativos, contexto.

A performance como movimento artístico e autônomo ganha força durante os anos 1970. Na prática performática o artista utiliza seu corpo como suporte, atitude política contra o objeto-produto de arte instituído e precificado. A Arte Conceitual, em voga na época, reiterou o sentido da prática performática ao propor uma arte não material, na qual a ideia atribuída à criação fosse sobressalente a qualquer intenção mercadológica, como reitera a autora Lucy Lippard: "Para mí, el arte conceptual significa una obra em la que la idea tiene suma importância y la forma material es secundaria, de poca entidade, efimera, barata, sin pretensiones $y / 0$ desmaterializada." (LIPPARD, 2004, p.9). A autora ressalta massiva inserção de artistas mulheres no circuito na década de 1970, alegando que os meios de execução como vídeo, performance, fotografia, poemas, textos, livros de artistas, facilitou o acesso e a participação das mesmas, possibilitando que as artistas daquele período pudessem, através do registro, inserirem-se na história da arte. Grande parte da discussão travada por essas artistas se debruçou em questionamentos acerca do papel social da mulher, sua aparência, beleza, autobiografia político-feminista através do uso do próprio corpo.

\section{Abstract}

This article aims to explore some of the performance term assignments considerating fields of knowledge that this term involves, through the discussion from national and international authors and through some historical exemples. The purpose of this research is not to write a historiography of performance art, but to describe some exemples that help in the undertanding about what we think as performance.

Keywords:

performance, assignments, context.

Desde sua "pré-história", termo utilizado pelo o autor argentino Jorge Glusberg para aludir as manifestações performáticas nas vanguardas europeias, muitos outros termos foram utilizados para se referir a performance e entre eles estão Performance Art ou Arte da Performance, Body Art, Happening, Live Art e Lectures. Com tantos designativos é confuso traçar a diferenciação de cada um em relação à performance, mas o que importa salientar é que todos eles estão decodificados dentro do campo da experimentação artística.

No livro intitulado A Arte da Performance, de Jorge Glusberg, o autor afirma que Body Art foi um termo cunhado para tratar de toda manifestação artística que abarcasse a utilização do corpo como veículo de expressão, assim como alega a pesquisadora canadense Amy Dempsey que "A body art é aquela que usa o corpo, geralmente o próprio corpo do artista como um meio. Desde o fim da década de 60 foi uma das mais populares e controvertidas formas de arte e disseminou-se pelo mundo." (DEMPSEY, 2003, p.244). Este guia enciclopédico, da autora citada, denominado de Estilos, Escolas 
e Movimentos, é como um dicionário artístico, pelo qual se busca o movimento estilístico e, por consequência, obtém-se sua contextualização histórica. 0 curioso é que neste guia enciclopédico o termo Arte Performática, outro designativo de Arte da Performance ou Performance Art, está compreendido entre o período de 1945 - 1965, enquanto Body Art se encaixa no período de 1965 até os dias de hoje. Essa observação é pertinente, pois se trouxermos uma das passagens em que Jorge Glusberg analisa a Body Art, a impressão que temos é que a Body Art abriu caminhos para a Arte da Performance, e não o oposto, quando da referência a artistas como Vito Aconcci, Daniel Buren e Gina Pane:

O denominador comum de todas essas propostas era o de fetichizar o corpo humano - eliminando toda exaltação à beleza a que ele foi elevado durante séculos pela literatura, pintura e escultura - para trazê-lo a sua verdadeira função: a de instrumento do homem, do qual por sua vez, depende o homem. Em outras palavras, a body art se constitui numa atividade cujo objeto é aquele que geralmente usamos como instrumento. (...) Ao mesmo tempo, a body art se diluía dentro de um gênero mais amplo - a performance. Enquanto a body art se expandia pela América, Europa e Japão, outros pesquisadores interessados em pesquisar novos modos de comunicação e significação convergem para uma prática que, apesar de utilizar o corpo como matériaprima, não se reduz somente à exploração de suas capacidades, incorporando também outros aspectos, tanto individuais como sociais, vinculados com o princípio básico de transformar o artista em sua própria obra, ou, melhor ainda, em sujeito e objeto de sua arte. (GLUSBERG, 2007, p.43).

O Happening, manifestação artística que tem como expoente significativo o americano Allan Kaprow, influente do grupo intermidiático FLUXUS, geralmente é ligado à ideia de improvisação simultaneamente à participação do público. "A tradução literal de happening é acontecimento, ocorrência, evento. Aplica-se essa designação a um espectro de manifestações que incluem várias mídias, como artes plásticas, teatro, art-collage, música, dança etc." (COHEN, 2002, p.46). Essa definição se aplica também a performance, visto que não foi mencionado o caráter eventual do happening, o que é recorrente quando se trata da intenção de diferenciar o happening da performance. Muitos happenings possuem essa característica, a citar o evento do Grupo Rex , de São Paulo e atuante na década de 1960, com sua Exposição-NãoExposição, um happening de encerramento de sua atividade no qual o público tinha liberdade de fazer o que bem entendesse com as obras ali expostas, tendo a exposição durada apenas 8 minutos, pois acabou na total destruição daquilo que estava dentro da sede do grupo.

Se a diferenciação entre performance e happening se dá pelo caráter de eventualidade, tal diferença só é possível através do conhecimento do quanto há de fortuito neste ou naquele. É muito arriscado diferenciar os dois termos práticos por esse viés, apesar de ser o mais aceito, visto que no embate que a performance traz entre corpo, tempo, espaço e público, que por vezes não é um público convidado, ou seja, o qual não se conhece, a eventualidade está presente. Portanto, talvez o que difira o happening seja o caráter participativo dado ao público, o que faz com que a eventualidade faça parte da proposta. E se pensarmos que tal eventualidade é programada, essa tentativa de diferenciação é invalidada, pois por vezes é atribuído a performance a noção de delineação de um enredo, ou seja, atividade na qual se tem um mínimo de controle sobre o seu desenvolvimento. Se pensarmos ainda que a performance pode ser participativa, ou seja, que ela pode trazer um público para interagir e que isso implica riscos, talvez a diferenciação entre a prática do happening e a performance esteja na frequência da participação do público.

Para comprovar a ideia de improviso ligada ao happening, um dos mais conhecidos e realizados por Alan Kaprow, 18 Happenings in 6 parts, (Figura 01 e 02), de 1959, na Reuben Gallery, NY, foi ensaiado com bastante antecedência. E como tentativa de discernir a prática com seus alunos do California Institut Of Art, Alan Kaprow fazia experimentações denominadas por ele de Activities ou Atividades. De acordo com a pesquisadora brasileira Thaise Nardim, a diferença entre os Happenings e as Activities está na falta da necessidade de compartilhamento da ação com uma audiência imprescindível à sua execução e também pelas Activities constituírem roteiros elaborados, os quais os alunos seguiam, como exemplo (KELLEY apud NARDIM, 2004):

$$
\begin{gathered}
\text { (leito de rio seco) } \\
\text { Molhando uma pedra } \\
\text { Carregando-a rio abaixo até que esteja seca } \\
\text { Largando-a } \\
\text { Escolhendo, escolhendo, lá, outra pedra } \\
\text { Molhando-a } \\
\text { Carregando rio acima até secar. } \\
\text { Largando-a. }
\end{gathered}
$$



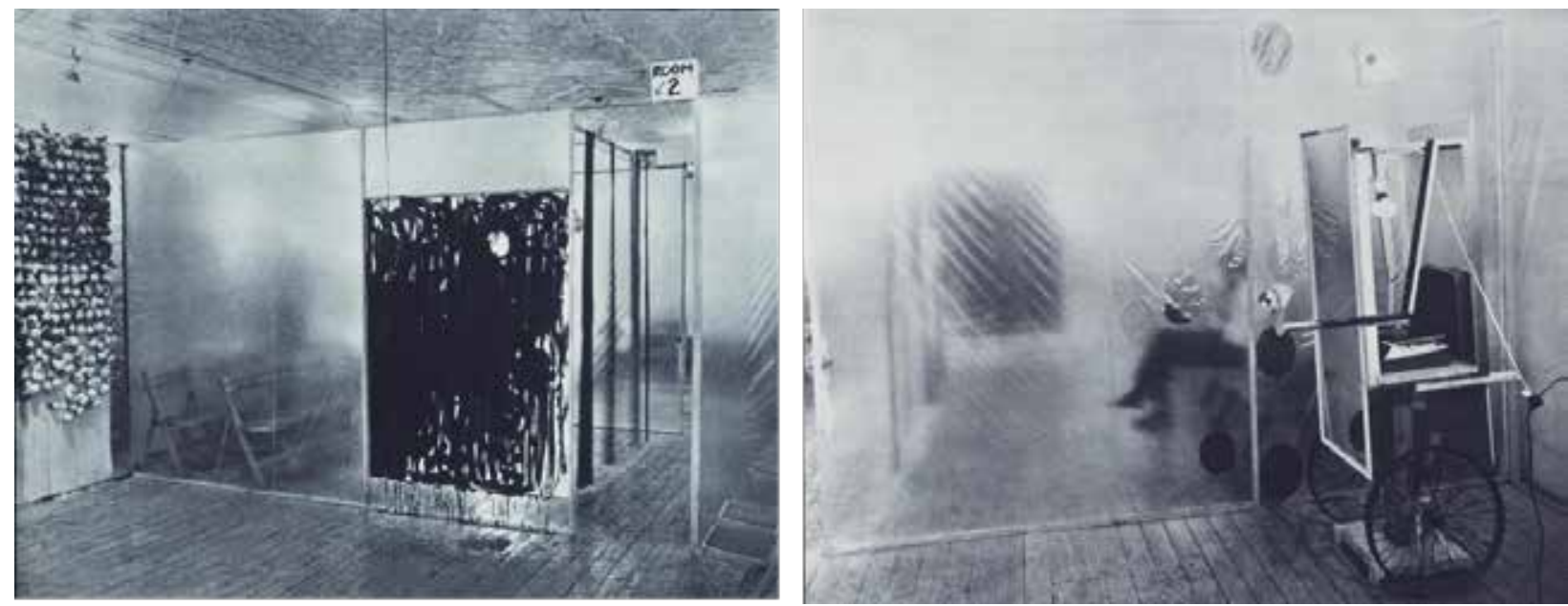

Figura 1 e 2 - Allan Kaprow, 18 Happenings in 6 Parts (1959), Ruben Gallery, New York. Fonte: https://cyberurchin.com

As Activities também surgem como uma resposta à crítica institucional que visava traçar nomenclaturas para os trabalhos de arte inovadores da época, como os happenings, e nessa tentativa de não adequação de seu trabalho com as nomenclaturas do mercado de arte, o artista denomina suas próximas realizações de Activities, aproximando tais a ideia de arte e não arte. Assim como Nardim, Glusberg aponta que o diferencial do Happenning para as Activities também está na ausência de uma plateia, pois Kaprow funde a figura do ator com espectador. Porém, ao analisarmos o Happening e as Activities, mais encontramos semelhanças do que diferenças entre elas para que seja necessária a criação de um segundo termo a fim de se referir a tais ações, pois em ambas as ações Kaprow coordena, através de um pequeno texto, um direcionamento, para que a ação aconteça dentro das possibilidades do imprevisto por ele. Talvez a marca das Activities resida no fato de que eram experimentações com alunos, e nada mais, o que não era uma premissa nos denominados Happennings.

Live Art é outro termo aplicado para designar as artes performativas, porém para a autora americana RoseLee Goldberg, ele faz jus à interdisciplinaridade utilizada por parte dos artistas para criarem seus experimentos corporais, e por isso é preferível utilizá-lo para nos referirmos a arte da performance quando ligada à música, teatro, dança, cinema ou artes visuais. Live Art ou arte ao vivo pode ser entendida como um designativo para qualquer manifestação, no âmbito artístico, em que o artista utilize do seu próprio corpo para produção de sentido: o corpo como suporte, a mensagem como obra, numa tentativa de aproximar arte e vida. 0 termo também está ligado a uma não representação, no sentido mimético-teatral.

O pesquisador brasileiro Renato Cohen afirma que a performance é intimamente ligada as artes cênicas, mas que a mesma rompe com os padrões aristotélicos de representação, narrativa e linearidade. Assim como a performance existem outras manifestações que visam romper com a ideia tradicional de teatro, como o Teatro da Crueldade do dramaturgo francês Antonin Artaud. Deste ponto de vista, o termo Live Art pode ser utilizado para qualquer âmbito artístico, desde que tal manifestação utilize o corpo como motor da obra e a desconstrução de paradigmas como índice, tendo suas origens nos finais dos anos 1990 e para a cofundadora do Live Art Development Agency, Lois Keidan "Live Art não deveria ser entendida como a descrição de uma forma de arte, mas sim, como uma estratégia de inclusão de uma diversidade de práticas e artistas que, em outras circunstâncias, se encontrariam "excluídos" de todos os tipos de política e de apoio e de toda espécie de trabalho de curadoria ou de debate crítico." Porém, já que o termo não se refere a ações específicas e sim com aspectos gerais ao que concerne à arte da performance, podemos dizer que Live Art e Body Art referenciam as mesmas questões: o corpo presente e o tempo real e cronológico em oposição ao tempo experimentado internamente. Não que o artista utilize apenas seu corpo em uma dada ação, mas o importante é frisar que seu corpo é o motor da obra, o fundamental, o suporte, o próprio canvas. 
Nos anos 70, o termo Lectures, ou Leituras, era muito utilizado para se referir a ações performáticas, visto que muitos artistas que faziam performance faziam também publicações de artistas. A recorrência deste termo é encontrada nos arquivos da Fundação Franklin Furnace, fundada por Martha Wilson, em 1976. Muitos artistas que trabalhavam com arte efêmera produziam publicações de artistas, isto é, eles criavam algum tipo de registro impresso ou à escrita que tinham a ver com seus trabalhos, como uma extensão dos mesmos, servindo de apoio ao trabalho. 0 acervo de publicações de artistas do Franklin Furnace se tornou o maior dos EUA, e em 1993 o MoMa o adquiriu, denotando a importância de tal iniciativa. As publicações de artistas funcionavam como um display alternativo para a divulgação do trabalho ou como seu suporte, visto que na época da fundação as instituições desconsideravam a relevância de artes efêmeras, como instalações, publicações e performances. A ideia de Lectures, partindo dos eventos da Franklin Furnace, consistia em apresentações com esses artistas que produziam publicações e performances a ler tais materiais impressos pertencentes ao acervo em algum evento promovido pela fundação. "Desse modo, a página impressa estava sendo considerada não apenas um espaço alternativo, mas era possível entender como as performances (Leituras) davam forma corporal àquelas ideias impressas, expandindo assim a própria noção de publicação." (BORBA; MELIM, 2014, p.85).

Lectures se mostra como um termo que visou especificar uma manifestação performática em um dado micro - contexto (específico), isto é, não se tratava da produção de performance como um todo, nos anos 1960, nos EUA, mas uma parte desse todo, uma parcela de tal produção, na qual a performance consistia na leitura de arquivos pessoais, portfólios, textos de artistas, os quais incorporados ao serem verbalizados pelos próprios autores, eram denominados de Lectures. Se compararmos com os termos designativos que vimos até aqui, podemos perceber que a distinção de Lectures para Performance se dá devido à um padrão na forma de apresentação: texto - artista - corpo presente leitura verbal. Porém, uma nova contradição vem à tona com essa afirmação, pois nos Happenings e Activities, por exemplo, também há um padrão na forma de apresentação.
A pesquisadora brasileira em artes cênicas Beth Lopes afirma que o campo de estudos sobre performance no Brasil ainda está muito ligado as artes visuais, o que nos faz pensar que o termo pode abranger outros campos do conhecimento. Beth Lopes é encenadora e professora brasileira de teatro. Sua pesquisa teórico-prática nesse campo de atuação analisa o conceito de memória como elemento potencial para que um performer estabeleça ou desconstrua laços de identidades coletiva ou individual na criação de uma performance, visto que quando ela utiliza o termo performer em vez de ator ela se refere "aquele que não se restringe à interpretação teatral no sentido convencional, mas transita por diferentes campos do conhecimento, desfronteriza as linguagens, amplia as noções espaciotemporais e fricciona as relações entre o real e o ficcional incorporando estados emocionais, subjetividades, memórias, criando a sua poética particular." (LOPES, 2010, p. 135)

Para o sociólogo canadense Erving Goffman, o termo performance está intimamente ligado as nossas ações banais e do cotidiano, ações desempenhadas pelo denominado ator social, o qual escolhe seu contexto de atuação, sua vestimenta e seu comportamento para se adequar a uma determinada situação e desempenhar um papel social ou uma performance social.

\begin{abstract}
A sociedade estabelece os meios de categorizar as pessoas e o total de atributos considerados como comuns e naturais para os membros de cada uma dessas categorias: Os ambientes sociais estabelecem as categorias de pessoas que têm probabilidade de serem neles encontradas. As rotinas de relação social em ambientes estabelecidos nos permitem um relacionamento com "outras pessoas" previstas sem atenção ou reflexão particular. Então, quando um estranho nos é apresentado, os primeiros aspectos nos permitem prever a sua categoria e os seus atributos, a sua "identidade social". (GOFFMAN, 2004, p.2)
\end{abstract}

Na citação acima, Goffman traz um breve apontamento sobre as construções de identidades sociais, isto é, uma construção identitária que visa tornar o indivíduo um objeto comum e reconhecível no cotidiano social. Por exemplo, quando o autor faz referência a ambientes sociais, ele discorre sobre um lugar possível em que se sabe onde encontrar pessoas específicas e que irão desempenhar um papel ou uma performance do cotidiano que seja conveniente com nossas expectativas. Pode-se pensar nos hospitais e seus funcionários ou mesmo em um bar onde. 
Desses locais espera-se encontrar indivíduos compatíveis com tais escolhas, ou seja, indivíduos sociais ou performers sociais.

Existe a concepção da performance antropológica, abordada pela pesquisadora e fundadora do Instituto Hemisférico de Performance e Política Diane Taylor, em entrevista concedida em 2002 ao projeto interdisciplinar e digital Scalar :

\begin{abstract}
Euacho muito difícil definir os estudos da performance, porque eles são claramente formados por várias disciplinas e diferentes modos de pensar sobre comportamento corporal. Temos a antropologia, temos a sociologia, temos a fenomenologia, temos a escola francesa, de [Jean-François] Lyotard em diante, tratando da performance. Por isso eu acho difícil definir se é somente um objeto de análise, se é uma praxe, se é uma episteme, um meio de conhecimento, se é uma transação comercial, se é uma medida de eficácia. O que importa para mim em relação à performance, e aos estudos da performance, é que ela nos permite olhar para todas essas coisas como se constituindo mutuamente, de maneira que não dá para pensar sobre comportamento e práticas corporais sem pensar sobre performances disciplinares - como construímos gênero, como construímos raça, e como somos construídos como corpos - mas ao mesmo tempo há um aspecto verdadeira e maravilhosamente libertador e contestatório, porque podemos performar de maneiras diferentes; a performance refere-se a uma ação, a uma intervenção, a uma quebra estrutural e a uma busca de novas alternativas. Por isso eu acredito que os estudos da performance não são uma coisa específica, e que a sua polivalência é, na realidade, o que há de mais promissor nesse campo.
\end{abstract}

A amplitude da discussão do termo performance também é debate no grupo brasileiro pioneiro de estudos em Antropologia da Performance, o Napedra. Coordenado pelo professor e pesquisador John C. Dawsey, os debates ligados a performance ocorrem através da aproximação entre Antropologia e Teatro, visto que os teóricos fundamentais para o grupo são Victor Turner, antropólogo britânico, e Richard Schechner, diretor americano de teatro. Para a Antropologia da Performance, ainda é possível realizar seu estudo e análise a partir da Linguística. Tais apontamentos reiteram o caráter interdisciplinar ligado ao termo performance, independente da área fenomenológica em que ela é analisada e ampliam seu campo de conhecimento e debate no Brasil.

Para Richard Schechner, teórico influente sobre as pesquisas do grupo Napedra
Em grupos acadêmicos e artísticos, o conceito de performance adquire formas variadas, cambiantes e híbridas; há algo de não resolvido neste conceito, que resiste às tentativas de definições conclusivas ou delimitações disciplinares. Aquém ou além de uma disciplina, ou até mesmo de um campo interdisciplinar, os estudos de performance configuram para alguns autores uma espécie de antidisciplina. A partir de diferentes campos do saber e expressão artística - desde o teatro e as artes performativas à antropologia, sociologia, psicanálise, linguística, pesquisas sobre folclore e estudos de gênero - formula-se o conceito performance.

Um ponto interessante trazido pelo autor brasileiro JoséMário Peixoto Santos se trata da contextualização do surgimento da linguagem da arte da performance nos anos 1970. A isto, ele se refere:

Nesse contexto artístico-histórico, surgiram os movimentos hippie; feminista; gay; estudantil; também a luta pelos direitos civis dos negros e contra o preconceito racial; a valorização de atitudes ecológicas e espiritualistas (Woodstock; Literatura Beatnick; Stonewall Inn; Maio de 1968 na França; os Black Panters em legítima defesa; a chegada de mestres espirituais da Índia ao Ocidente a exemplo dos yogis Acharya Rajneesh, Osho, e A.C. Bhaktivedanta Swami Srila Prabhupada, fundador do Movimento Hare Krishna), além de outras reivindicações relacionadas aos direitos humanos na contemporaneidade - movimento mais abrangentemente conhecido como contracultura.

Em campos acadêmicos e artísticos, o conceito de performance adquire formas variadas, cambiantes e híbridas. Há algo de não resolvido neste conceito que resiste às tentativas de definições conclusivas ou delimitações disciplinares. (...) A partir de diferentes campos do saber e expressões artísticas - desde o teatro e as artes performativas à Antropologia, Sociologia, Psicanálise, Lingüística, pesquisas sobre folclore, e estudos de gênero - formula-se o conceito de performance. (DAWSEY, s/p, 2010.)

Pode-se concluir que todos os termos criados para se referir a performance são termos cunhados historicamente a fim de se refletir sobre o próprio desenvolvimento da prática performática. Visto que é uma linguagem recente, estes termos servem de caminhos e direções, tanto para artistas quanto para críticos teóricos, sobre o que esteve e está sendo produzido no campo da arte ao vivo. As delimitações dos termos estão menos associados a demarcar o que é performance do que a reconhecer o que é o processo de performance, pois o processo é muito mais amplo e muitas vezes não condiz com um termo fechado em si mesmo, mas com aspectos de diferentes termos. Por exemplo, 18 Happenings In 6 Parts, como já mencionado, é tido como um 
evento de ações fortuitas, não programadas e espontâneas, características do happening. Porém ao se estudar sobre este acontecimento, sabese que houve ensaios antes da apresentação e que no decorrer dela todas as ações do público eram guiadas pelo artista propositor da ação, sendo assim destituída a noção de que o público participava espontaneamente. Para alguns críticos, a performance é tida como uma ação mais elaborada em relação ao happening, a qual contém um script, por exemplo. Na ação de Alan Kaprow, vê-se que o maior happening reconhecido pela história da arte na verdade tem características tanto do happening, como conceito bem definido, como da performance, e é por isso que não é possível encaixar as ações performáticas em termos delimitados, e talvez por isso exista tantos termos, pois com a necessidade de se delimitar o que é performance também se tem a necessidade de delimitar o que é parecido com ela.

O corpo é veiculo de comunicação no cotidiano, em nossas relações com o mundo. A pesquisadora brasileira Christine Greiner reitera a importância do corpo como motor de relações expressivas:

o próprio corpo resulta de contínuas negociações de informações com o ambiente e carrega esse seu modo de existir para outras instâncias de seu funcionamento. Cada tipo de aprendizado traz ao corpo uma rede particular de conexões. Quando se aprende um movimento, aprende-se junto o que vem antes e o que vem depois dele. Nesse aspecto, vê-se instalada no corpo a própria condição de estar vivo e ela se apoia basicamente no sucesso da transferência permanente de informação. (GREINER, 2011).

Talvez o fato de que nossos movimentos corporais estejam estritamente associados a um tipo de comunicação funcional, a qual por vezes se torna uma ferramenta de alienação para uma compreensão mais profunda do outro, ler uma performance pode ser uma tarefa complexa para qualquer espectador, pois a quebra de sintaxe que corresponde a um gesto e seu significado cotidiano é rompido e portanto incompreendido quando fora de contexto. O autor argentino Jorge Glusberg descreve que na performance

Os programas comportamentais e gestuais não vão responder, exceto em certos casos, às convenções comuns, e sim, ao invés disso, impor novos significados, totalizando uniões de campos semânticos, dinâmicos e flexíveis. A essência, e acreditamos que isso seja fundamental, é que a body art e a performance não trabalham com o corpo, mas com o discurso do corpo. Porém a codificação a que está submetido o discurso é oposta as convenções tradicionais; embora parta das linguagens tradicionais ela acaba por entrar em conflito com elas. (GLUSBER, 2007, p.56-57)

Isso faz com que o espectador não consiga dispor de um pressuposto conotativo das ações executadas pelo performer com as ações que ele reconhece funcionalmente no mundo, ou seja, não é possível conceber a performance com a facilidade com a qual se concebe os atos cotidianos. Há uma naturalização do corpo como veiculo funcional, desprovido de significado e expressividades comunicantes. $\mathrm{Na}$ performance o corpo funcional é transgredido e o público se depara com a tentativa de conceber a ação de forma racional, o que na realidade pode ser impossível, visto que a ressignificação pressupõe novas formas de pensar o corpo.

Acredito que a relevância do discurso do corpo está justamente na quebra de significado/ significante e na sequente incompreensão do ato, pois em um mundo onde a certeza detentora de conhecimentos é preponderante, o espaço para uma inteligência imaginativa não é instigado e não se desenvolve, trazendo preconceitos em relação à arte da performance. A crítica de arte mexicana Avelina Lesper redigiu um texto chamado Contra el Performance, no qual ela visa menosprezar a performance como meio e discurso.

La gran inspiración de muchas de estas acciones son los programas de concurso y los reality-shows en los que someten a pruebas absurdas y degradantes a los concursantes, quienes por pobreza o sed de fama se humillan para ganarse un premio. (...) Un movimiento que surgió como rompimiento, y que no requería de comprensión, ha degenerado en obras que acumulan explicaciones y discursos alineados con el statu quo. Ninguna de estas manifestaciones demuestra talento, técnica, lenguaje o capacidad creadora.

O discurso de Avelina Lesper é claramente moderno quando ela tenta descreditar a performance como prática artística. A autora desconsidera a pluralidade de artistas performáticos existentes na atualidade e no passado e suas pesquisas artísticas, reduzindo toda performance a uma pesquisa sobre reality show. Talento e técnica remetem a execução de uma pintura renascentista e não só ela é arte. Tomo a liberdade de narrar este trecho em primeira pessoa, por ser pesquisadora e artista visual com produção em performance, para exemplificar uma visão oposta. Para mim, a performance é feita com trabalho e reflexão, e o talento para preconcebê- 
la não se ajusta a esse debate, pois ele se faz com trabalho, ele é consequência, apesar de ser um termo muito romântico e que pressupõe o mito do artista como gênio. O repúdio dessa crítica mexicana contra a performance se dá pela comentada complexidade de leitura de imagem em performance e por ela ser uma manifestação da pós-modernidade, a qual Avelina é resistente em compreender. Seu discurso se estagna na reiteração de seu gosto pessoal e purista, o que não é um problema, mas apenas um fato explanado.

A americana Peggy Phelan defende que a partir do momento em que uma performance é registrada ela perde seu caráter qualitativo que a coloca nessa categoria, e é com a seguinte passagem que Peggy inicia o livro A Ontologia da Performance:

\section{A única vida da performance dá-se no presente. A performance não pode ser guardada, registada, documentada ou participar de qualquer outro modo na circulação de representações de representações; no exato momento em que o fia, ela toma-se imediatamente numa coisa diferente da performance. E na medida em que a performance tenta entrar na economia da reprodução que ela trai e diminui a promessa da sua própria ontologia. O ser da performance, tal como a ontologia da subjetividade que aqui é proposta, atinge- -se por via da desaparição.(PHELAN, 1997, p171)}

Felizmente ou não, a documentação de performance, desde a década de 1960 e iniciada por artistas, como exemplo o acervo da Franklin Furnace , de Martha Wilson, é de extrema importância para se conhecer e analisar obras que não são mais possíveis de se presenciarem ao vivo por seu caráter efêmero. Esses documentos de registros serviam e ainda servem de apoio material e reflexivo aos artistas e para o desenvolvimento de sua poética. Porém, quando a autora Peggy Phelan infere que a performance quando registrada por qualquer meio perde seu caráter qualitativo de performance, pode-se subentender que performances que sejam executadas para vídeo ou fotografia na verdade não são performances, pois o registro como escolha consciente de apresentação do trabalho é inferior a ação ao vivo. Mas e como fica a intensão do artista em relação à apresentação do próprio trabalho? A sugestão de Peggy Phelan é cabível quando se pensa, por exemplo, em um registro não intencional de performance, ou seja, um registro de qualquer pessoa do público ou instituição. Talvez a passagem de Peggy seja uma forma não intencional de tornar o performer um ingênuo em relação às imagens que são produzidas por suas ações.
Uma vídeo-performance ou foto-performance não deve ser equiparada a uma performance ao vivo se para compará-las qualitativamente, pois o tempo do vídeo e da performance ao vivo, por exemplo, são diferentes. A performance no vídeo existe independente de ser acionado, é um tempo resguardado. Tem-se a ação performática a qualquer momento em que se executar o vídeo, e a qualidade da apresentação, nesse caso, está ligada ao display, isto é, ao tamanho, formato e tipo de aparato que irá se exibir tal vídeo, visto que hoje temos projeções que alcançam dimensões exorbitantes e sem perder a qualidade da imagem, bem como televisores cada vez maiores e mais tecnológicos. Assistir a uma vídeo-performance no Youtube e na tela padrão do computador não é tão interessante visualmente quanto assisti-la em uma tela de projeção com tamanho e qualidade que não estejamos habituados em nossa casa. Porém a ação performática no vídeo, independente do display, continua a mesma e sem alteração no tempo e espaço interno da imagem do vídeo.

Quando Peggy Phelan discorre sobre "desaparição" em performance, ela está se referindo justamente a falta de possibilidade de um novo acesso e repetição dessa ação, pois a repetição é vista como uma característica e estratégia de mercado, logo negativamente. Porém, tem-se sempre que levar em consideração a intencionalidade do artista ao escolher apresentar por diferentes meios a materialização de seu processo criativo.

O artista desenvolve a performance, a qual se pode tomar como um produto de arte, porém efêmero, se considerada como arte ao vivo devido à sua duração e materialização da presença se dar em um período pré-estabelecido, curto ou longo, mas que jamais será o mesmo de uma obra de arte convencional que perdura por anos como um mesmo objeto e por vezes num determinado local. Talvez não seja necessário atribuir a performance apenas o tempo presente como um elemento estético e de fator decisivo, mas apenas ter consciência da utilização do tempo vídeo e do tempo presente.

Lucio Agra, pesquisador brasileiro é um grande fomentador da discussão da performance em São Paulo e no Brasil nos últimos anos. Junto a demais pesquisadores, ele organiza a Associação Brasil Performance, a fim de mapear os festivais e eventos realizados no país, assim como fóruns 
de debates permanentes. Para Agra, o Brasil é referência em produção e pioneirismo sobre o assunto na América Latina, visto que as datas das experiências do artista Flávio de Carvalho não têm precedentes nessa grande região.

Agra sugere que a performance seja uma "perfeita tradução do contemporâneo" (AGRA, 2011, p. 16) e isso remete às discussões travadas sobre o conceito de pós-modernidade a partir de autores como o francês Jean François Lyotard e o americano Frederic Jameson, discorrendo sobre algo que desencadeia na percepção da constante atualização do presente na pós-modernidade: a perda da noção de história linear, e logo de um passado concreto calcado por grandes narrativas, reiterada pelo acesso a hiperlinks, pelos quais o presente é constituído de informações passageiras, líquidas , trazendo a efemeridade do tempo/duração contida na performance como elemento estético como possível forma fenomênica e singular da pós-modernidade e a imprevisibilidade contida em tais atualizações do presente. Por isso, para concluir este capítulo, utilizo do parágrafo de conclusão de Agra em sua publicação na Revista de Pós-graduação da UnB, 2012:

Se ainda assim se quiser outras razões, resumo as expostas aqui: o caráter de expansão da linguagem, sobretudo atualmente; a sua "natural" resistência à apreensão cognitiva racionalista, a sua amplificação geográfica, a sua reverberação em vários contextos (ela mesma sendo um), sua congenialidade a outras formas emergentes de invenção artística que resultam de misturas e apropriações de formas tradicionais ou sucatas culturais, a sua predileção pelo evento efêmero, precário, dificilmente apreensível, a sua resistência às clássicas ordens identitárias, o seu caráter de proximidade ao subalterno, sua expansão em lugares antes ignotos, sua formulação em uma temporalidade espiralada (sem a teleológica perspectiva de um progresso linear-ascendente), a amplitude de seu campo de pesquisa, sua ilógica, sua predileção pelo paradoxo, o experimental. Por que deveríamos abrir mão desta conquista que é dispormos de um modo de dizer/fazer/pensar em arte que resiste às definições? Vamos adiante afirmando a dúvida.

É interessante notar como estudiosos da performance reconhecem a dificuldade em delimitá-la, isto é, torná-la um conceito fechado em si mesmo, pois talvez delimitar o seu significado esteja relacionado a uma falta de compreensão da amplitude e hibridez que há em sua teoria e prática. Talvez não se trate de analisar o termo como um designativo geral e panorâmico de uma prática, mas as práticas pelas quais se constitui a performance.

\section{NOTAS}

1. Intermídia é um termo criado pelo fundador do FLUXUS, George Maciunas, para designar a integração e hibridização entre diferentes linguagens ligadas a arte e a cultura em uma mesma manifestação artística.

2. O Grupo Rex foi fundado pelos artistas Wesley Duke Lee, Geraldo de Barros e Nelson Leirner. 0 intuito do grupo era fazer experimentações com diversas linguagens, atualizando o cenário brasileiro ao realizarem controversas obras de arte e exposições ligadas ao happening internacional. As atividades do grupo são muitas vezes comparadas as atividades do FLUXUS.

3. Teatro da Crueldade é uma teoria teatral proposta por Antonin Artaud, como uma crítica à espetacularização, racionalização e à sociedade ocidental. Era preciso, pois um novo teatro e um novo espectador para romper paradigmas e para isso ele calcou a estruturação de tal proposta na condição pré-verbal e na psique humana.

4. A Franklin Furnace funciona até os dias de hoje, e seu papel fundamentou consistiu na catalogação, documentação, promoção e preservação de artes efêmeras, como livros de artistas, instalações, vídeos e performances ao vivo ou online.

5. O Instituto Hemisférico de Performance e Política, criado em 1998, é uma rede multilíngue e interdisciplinar de instituições, artistas, acadêmicos e ativistas políticos de todas as partes das Américas que trabalha na interseção entre a academia, expressão artística e a política. A organização explora as práticas do corpo - a performance - como veículo para a criação de novos significados e a transmissão de valores culturais, de memória e de identidade. Fonte: http://hemisphericinstitute.org/hemi/pt

6. O projeto Scalar faz a mesma pergunta a trinta acadêmicos de diferentes países das Américas: 0 que são estudos de performance?

Fonte: http://scalar.usc.edu/nehvectors/wips/ diana-taylor-portuguese

7. Núcleo de Antropologia, Performance e Drama Universidade de São Paulo, Brasil.

8. DAWSEY; John C. MÜLLER, Regina; HIKIJI, Rose S. G; MONTEIRO, Marianna F. M. Antropologia e Performance: Ensaios Napedra. São Paulo: Terceiro Nome, 2013, p18. 
9. A Franklin Furnace funciona até os dias de hoje, e seu papel fundamentou consistiu na catalogação, documentação, promoção e preservação de artes efêmeras, como livros de artistas, instalações, vídeos e performances ao vivo ou online.

10. MEDEIROS, Maria Beatriz de. Corpos informáticos: arte, corpo, tecnologia. Brasília, DF: FAC: UnB, 2006.

11. "A Associação nasce em 2010, com a necessidade de dialogar com o meio cultural e artístico brasileiro e internacional, a fim de pensar e reivindicar incentivos duradouros para a performance no Brasil. Uma das tarefas da BrP, é o mapeamento da performance em São Paulo e no Brasil, necessidade evidenciada a partir das discussões dos Fóruns nas quais sempre se repetia a pergunta: quem somos? A BrP é uma associação sem fins lucrativos, aberta a todos, interessados, artistas e estudiosos da performance." Fonte: http://brasilperformance. blogspot.com.br/

12. "Zygmunt Buman é um grande pensador polonês, e o qual qualificou tão bem o célebre conceito de liquidez. Perspicaz analista dos fatos cotidianos, o sociólogo tem vasta obra sobre temas contemporâneos, com destaque para o best-seller Amor líquido, fundamental para a compreensão das relações afetivas no mundo atual." Fonte: www. zahar.com.br.

\section{REFERÊNCIAS BIBLIOGRÁFICAS}

BORBA, Jenny Granado Rocha. Publicação de Artista e Performance: Intersecções Entre Visibilidade e Valor da Aparência, Revista DAPesquisa, v.9, n.12, p 01 - 14, dezembro 2014.

COHEN, Renato. Performance como linguagem. São Paulo: Perspectiva, 2002.

DAWSEY; John C. MÜLLER, Regina; HIKIJI, Rose S. G; MONTEIRO, Marianna F. M. Antropologia e Performance: Ensaios Napedra. São Paulo: Terceiro Nome, 2013.

DAWSEY, J. C. NAPEDRA - Núcleo de Antropologia, performance e drama: em busca do lugar sentido das coisas. IN: Proa - Revista de Antropologia e Arte [online]. Ano 02, vol.01, n. 02, nov. 2010. Disponível em: < http://www.ifch.unicamp.br/proa/Relatos\%20e\%20 Experienciasll/john.html. > Acesso em Maio 2016.
DEMPSY, Amy. Estilos, Escolas e Movimentos: Guia Enciclopédico da Arte Moderna. São Paulo: Cosac Naify, 2003.

GLUSBerg, Jorge. A Arte da Performance. São Paulo: Perspectiva, 2007.

GOLDBERG, Roselee. A Arte da Performance: Do Futurismo ao Presente. São Paulo: Martins Fontes, 2006.

GOFFMAN, Erving. Estigma: Notas sobre a manipulação da identidade deteriorada. Rio de Janeiro: Guanabara, 1991.

JAMESON, Fredric. Pós-modernismo: a logica cultural do capitalismo tardio. 2. ed. - Sao Paulo: Ática, 1997.

KEIDAN, Lois. Live Art. O que é Live Art? Disponível em:

< http://www.forumpermanente.org/revista/ edicao-0/textos/liveart > Acesso em: Maio, 2016.

LIPPARD, Lucy. Seis años: la desmaterialización del objeto artístico de 1966 a 1972. Madrid : Akal, 2004.

LYOTARD, Jean-François. A condição pósmoderna. 11. ed. Rio de Janeiro: J. Olympio, 2009.

MEDEIROS, Maria Beatriz de. Corpos informáticos: arte, corpo, tecnologia. Brasília, DF: FAC: UnB, 2006.

LOPES, Beth. A performance da memória. Revista Sala Preta, São Paulo, v.9, p. 135 a 145, 2009.

SANTOS, José Mario Peixoto. BREVE HISTÓRICO DA "PERFORMANCE ART" NO BRASIL E NO MUNDO. Revista Ohun, Bahia, n) 4, p.1-32, dez 2008.

TAYLOR, Diane. 0 que são estudos de performance? Disponível em:

< http://scalar.usc.edu/nehvectors/wips/dianataylor-portuguese > Acesso em: Abril, 2016. 


\section{SOBRE O AUTOR}

Natalie Mirêdia (artístico) é bacharel em Artes Plásticas pela Universidade Federal do Espírito Santo, UFES. Possui pesquisa de Iniciação Científica pelo CNPq na área de Teoria e História da Arte Moderna e Contemporânea e Performance Artística. Desenvolve trabalhos artísticos com performances, fotografias, vídeos e objetos a partir de sua pesquisa artística Qual o resultado da equação elementos delicados x agressivos? 2014. Já participou de mostras no Brasil e no exterior, como $2^{\circ}$ Caixa Bienal de Novos Artistas (Caixas Culturais) e Venice Experimental Video and Performance Art Festival, no Palazzo Ca Zanardi, Veneza. 


\section{Raquel Stolf UDESC}

\section{Resumo}

O presente texto apresenta investigações em torno de experiências de silêncio, bem como acerca de propostas de escrita, leitura e escuta que pendem segundo ângulos de suspensão (usos de uma palavra pênsil) e de processos que envolvem uma escuta porosa. Tais investigações movem o processo da publicação sonora assonâncias de silêncios [coleção] (2007-2010), que articula relações entre componentes sonoros e escritos, propondo situações de leitura e escuta de silêncios. Mas, se a maquinaria de sentido é algo difícil de interromper e suspender, como propor silêncios em/para outras escutas, em publicações sonoras? Talvez, pela diminuição da audição, trabalhando com audibilidades precárias? Ou tentando pausar o que se ouve no que se escuta? Partindo de outra premissa-interrogação: como ouvir, escutar e escrever-desenhar silêncios?

\section{Palavras-chave:}

notas-desenhos de escuta; silêncio acústico; palavra pênsil; escuta porosa

\section{0. frágil e inapreensível}

Em meus primeiros trabalhos em que o desenho está presente, lembro do processo de encostar a ponta do bico de pena na superfície do papel e durante alguns milímetros de segundo não saber para onde a linha preta de nanquim seguiria. Esse começo impreciso, inconcluso e imerso num nãosaber parece ser o motor de minhas relações com o desenho (e também com a escrita). 0 encontro com o em branco da folha de papel me atrai pela sua opacidade. E é nesse instante de quase-pausa de sentido que meu pensamento se move e que algum ruído começa.

Cildo Meireles, numa entrevista a Frederico de Morais (MEIRELES in SCOVINO, 2009, p.194), sublinha o ato de desenhar como um processo muito

\section{Abstract}

This paper presents some researches about silence experiences as well as about writing, reading and listening proposals, that move according to suspension angles (uses of a suspended word) and processes involving a porous listening. Such investigations move the process of sound publication assonâncias de silêncios [coleção] (2007-2010), that articulate relations between sound and written components by proposing situations of reading and listening silences. However, if the sense machinery is difficult to stop and suspend, how can one propose silences in/to other listening, in sound publications? Perhaps, by decreasing hearing, working with precarious audible facts? Or trying to pause what you hear in what you listen? Starting from another premise-question: how to hear, listen and writedraw silences?

Keywords:

listening notes-drawings; acoustic silence; suspended word; porous listening

rápido e diz que o desenho é uma unidade mínima de pensamento. E ainda, define o desenho contando uma experiência sua, de 1969:

\footnotetext{
Um dia, pela manhã, ao abrir a porta da casa, senti uma vibração estranha no ar. Por puro instinto, olhando à minha direita, fechei um 'copo-de-leite', em cujo interior estava um beija-flor. Foi algo indescritível: pegar um beija-flor com a mão apenas para ter o prazer de libertá-lo. 0 ato de desenhar me dá uma sensação semelhante: vivenciar algo muito rápido, quase inapreensível. 0 desenho é algo tão frágil e veloz como um beija-flor. (MEIRELES in SCOVINO, 2009, p.194-195)

$\mathrm{O}$ ato de desenhar parece ter algo a ver com perceber, tentar pensar e/ou produzir uma vibração alheia no ar. Desenho-escrevo quando alguma coisa parece estar suspensa e quase-apreendida, quando algo pende e ao mesmo tempo, pausa. Nem que seja
} por um instante. 


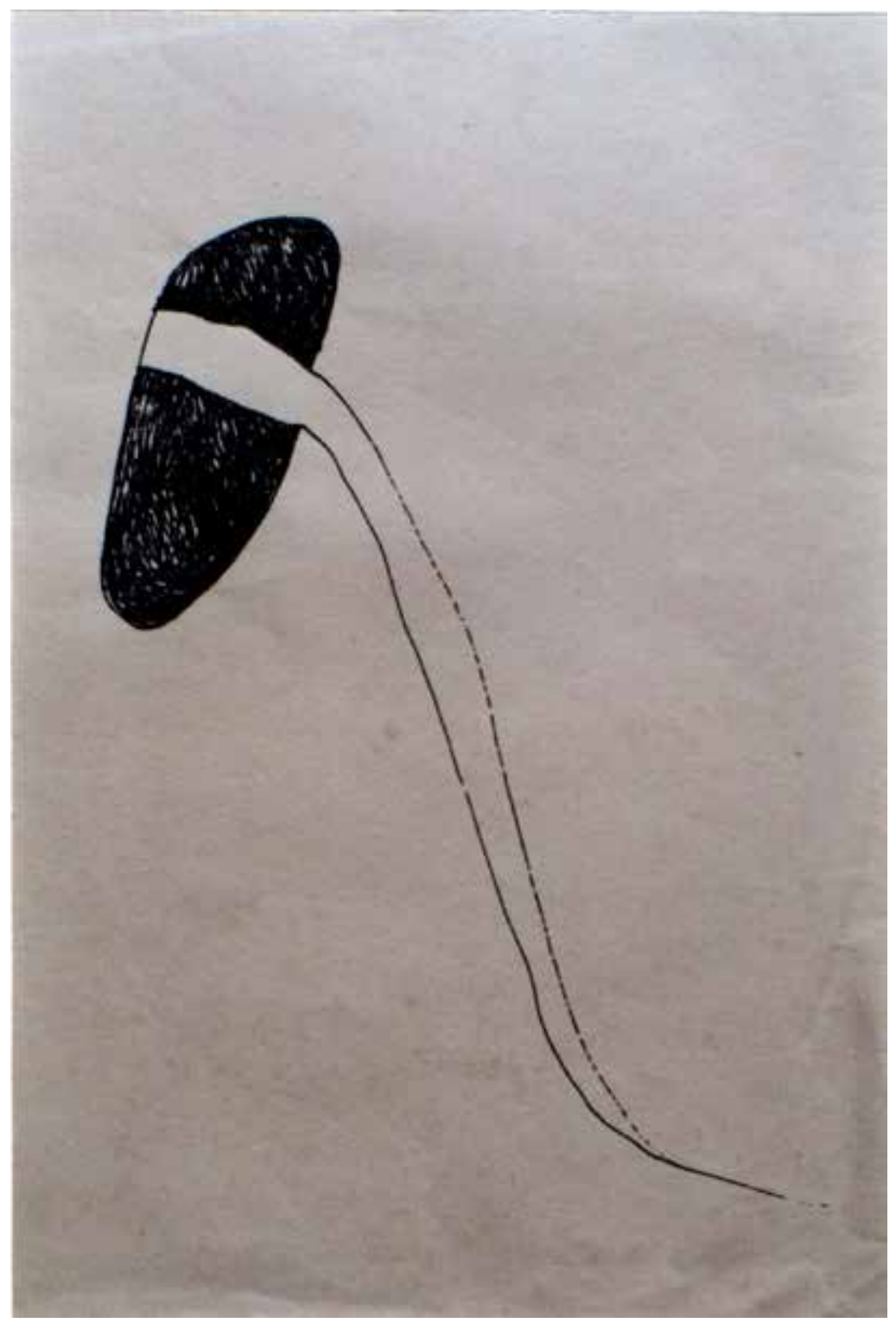

Figura 1 - Raquel Stolf, rabo do buraco, 1994. Desenho (nanquim sobre papel jornal), dimensões: $28 \mathrm{~cm} \times 20 \mathrm{~cm}$

\section{DESENHO COMO ANOTAÇÃO [DE ESCUTA]}

Por vezes, sinto-me mais lenta que um desenho, mais lenta que meu próprio pensamento (enquanto voz ou silêncio dentro da cabeça). Ou ainda, mais devagar que minha voz. Por vezes, desenhoescrevo em câmera-lenta.

Como escutar um desenho no instante em que ele é construído, (ar)riscado? Como escrever um desenho? Como lidar com uma palavra arisca? Como desenhar um silêncio? Como anotar/notar algo tentando reter alguma singularidade? Como apreender ou fisgar um silêncio sonoro? Com um texto que desvia? Com uma palavra pênsil? Com notas-desenhos? Como começar, construir e manter uma coleção de silêncios? Como construir um branco e/ou um zero na escuta?

Durante o processo de construção de uma coleção de silêncios que venho desenvolvendo desde 2007 (nos projetos assonâncias de silêncios ${ }^{2}$ e mar paradoxo3), percebi que foi necessário para a existência da coleção construir uma série de notas-desenhos de escuta. Elas suscitam relações entre micro-ruídos, desenho e escrita, articulando também usos do som, da palavra manuscrita e da 

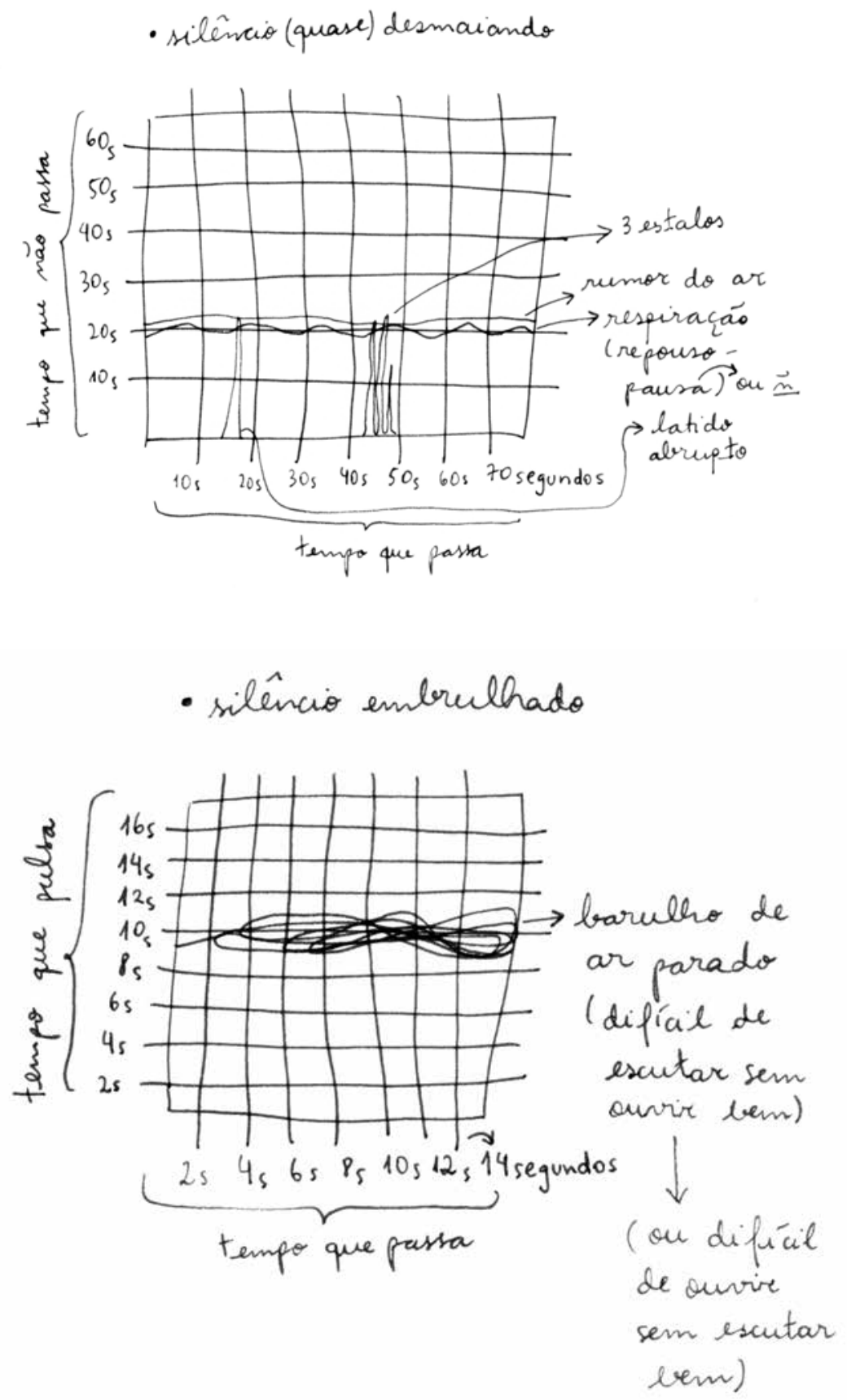

Figura 2 e 3 - Raquel Stolf, assonâncias de silêncios [coleção], 2007-2010. Detalhes de notas-desenhos de escuta da publicação.

ficção - que via Maurice Blanchot (1987, p.45-46), envolve "sair de si para uma fala errante", ou talvez, para um silêncio vagante.

Essas notas-desenhos fazem parte de impressos que compõem algumas publicações sonoras que integram os projetos, dentre elas, assonâncias de silêncios [coleção] (2007-2010), 60 silêncios empilhados (2010-2014) e mar paradoxo (20132016), entre outras publicações. A publicação assonâncias de silêncios [coleção] consiste numa coletânea de silêncios gravados em diferentes contextos, agrupados num $\mathrm{CD}$ de áudio, juntamente com material impresso, reunindo cinco "espécies de silêncios"4: silêncios preparados; silêncios acompanhados; silêncios com falhas; silêncios empilhados; fundo do mar sob ruído de fundo. A tipologia foi construída durante o processo de escuta, gravação e edição digital do disco, sendo que sua construção envolveu relações 


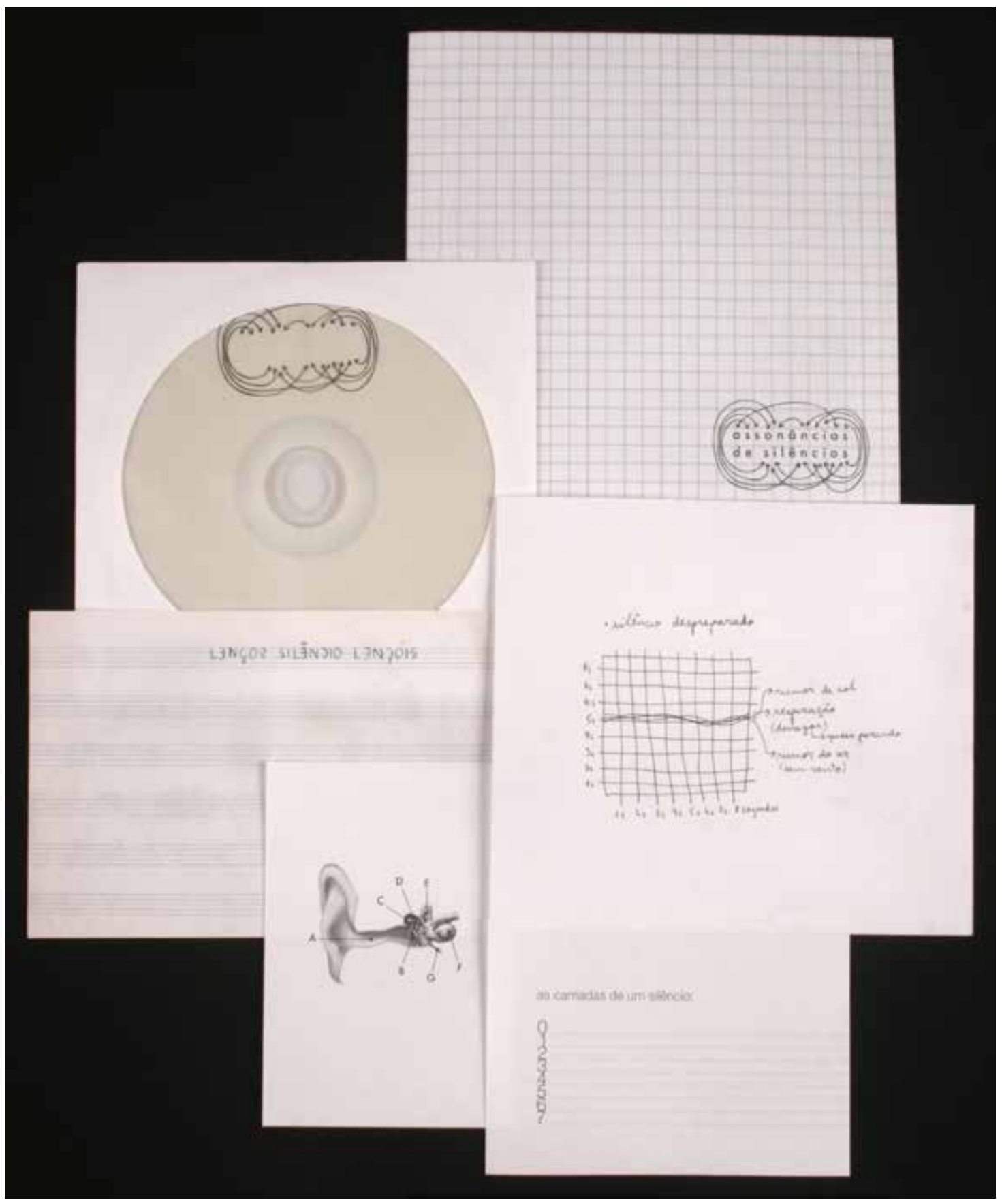

Figura 4 - Raquel Stolf, assonâncias de silêncios [coleção], 2007-2010. Vista da publicação sonora. Mais registros em: http://www.raquelstolf.com/?p=467

de interdependência entre os áudios e textos, palavras-partituras, notas-desenhos de escuta e fac-símiles preparados de páginas de cadernos de notação musical utilizados como cadernos de anotação-desenho.

O início do processo de gravação desencadeou uma série de dúvidas e investigações, envolvendo tanto períodos de crise e distanciamento, como de retomada diária da coleção. $\mathrm{E}$ foi nesse movimento entre ação e inação que o primeiro volume da coletânea (volume 0 ) foi concretizado.

Se o silêncio constitui uma questão mental, sendo um meio para começar a escutar e/ou a ouvir o que nos cerca - como nos aponta John Cage (1978): "o silêncio não existe"5 -, ao mesmo tempo, se não ficarmos em silêncio, não conseguiremos ouvir o que se passa ao redor, nem escutar as camadas de silêncios ou as texturas de rumor dentro de uma 

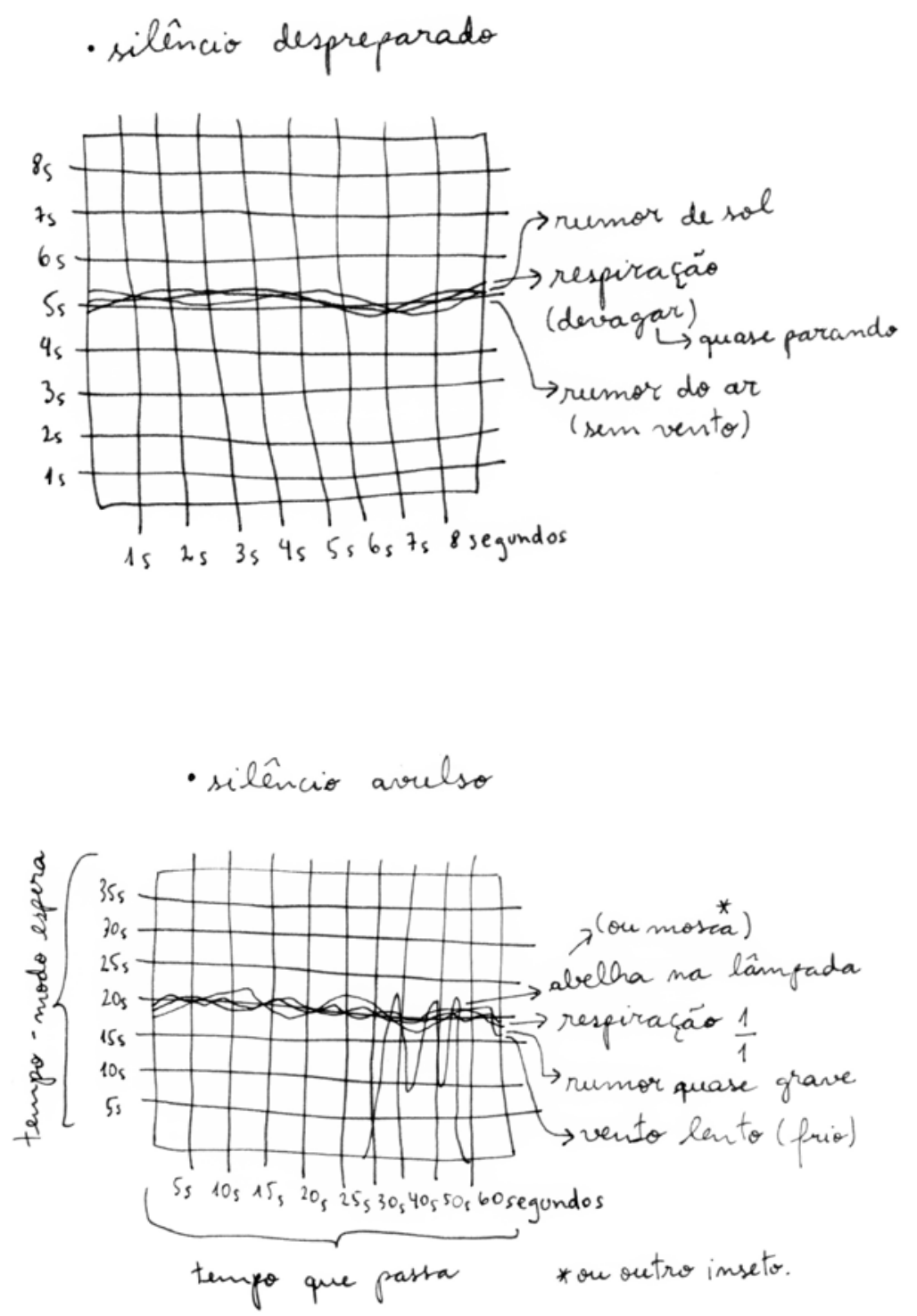

Figura 5 e 6 - Raquel Stolf, assonâncias de silêncios [coleção], 2007-2010. Detalhes de notas-desenhos de escuta da publicação.

massa de barulho. Esses exercícios ou posições de escuta foram necessários e presentes no processo de construção da publicação assonâncias de silêncios [coleção].

Passei a me interessar também não só pelo silêncio antes e depois da palavra, ou sendo por ela indicado (pois os títulos de cada silêncio e a tipologia indicada nos impressos do disco atravessam e tornam a coleção possível), mas também por um silêncio proposto a partir de um paradoxo linguístico. Um paradoxo presente na relação entre a figura de linguagem sonora da assonância e a tentativa de escutar um silêncio acústico.
Assim como as tipologias e os títulos de cada um dos cinqüenta silêncios do disco ${ }^{6}$, as notasdesenhos de escuta atravessam a coletânea de sons de diferentes maneiras. Elas foram escritasdesenhadas durante o processo de seleção, listagem e edição dos silêncios já gravados, numa espécie de escuta simultânea. E se no início consistiram em registros de experiências acústicas, enquanto anotações de processo, percebi que elas também lançam a possibilidade de um reenvio das situações sonoras/insonoras para o leitor-ouvinte (o silêncio enquanto situação). 


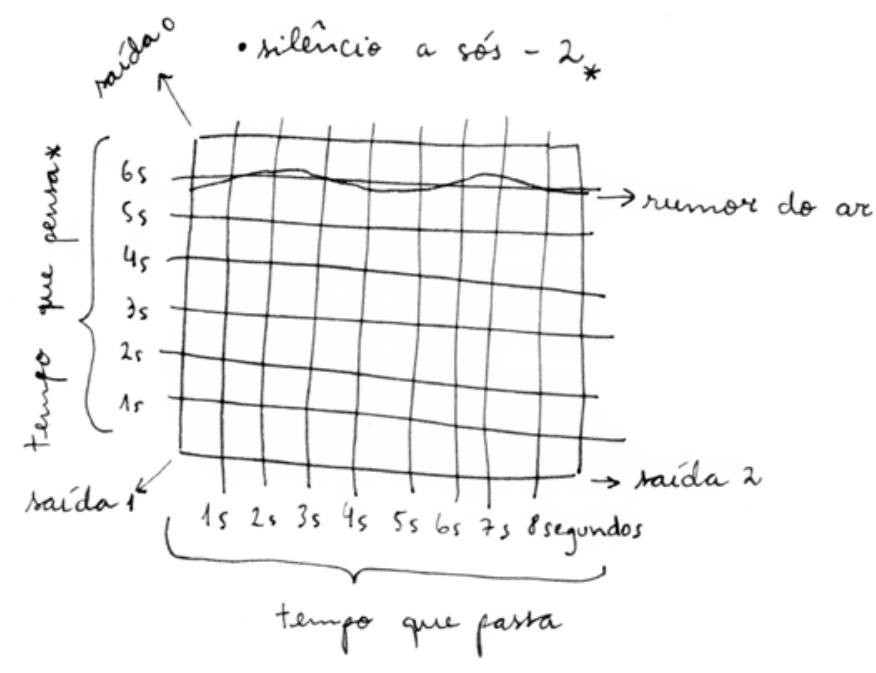

Figura 7 - Raquel Stolf, assonâncias de silêncios [coleção], 2007-2010. Detalhe de nota-desenho de escuta da publicação.

A partir desse momento, as notas-desenhos de escuta foram sendo pensadas enquanto proposições que coexistem e expandem os áudios. Foram sendo pensadas cada vez mais como possibilidades de reimaginar situações silenciosas, propondo também um lançamento da escuta para silêncios ainda inauditos, esboçados e diagramaticamente concatenados. Ou como projetos e proposições de outras espécies de silêncios: silêncio despreparado; a sós, extra, opaco, torto; (quase) desmaiando; pendurado; avulso; embrulhado; etc. Podem ainda ser pensadas enquanto palavras-partituras mistas, nas quais combina-se notas manuscritas com gráficos multi-temporais, simulando os desenhos de ondas sonoras (o que se conecta diretamente ao processo de edição digital de áudio e à visualização de um som). Palavras-partituras mistas que indicam silêncios através de (a)notações de sensações/ percepções infinitesimais (de amostras que duram segundos), silêncios que podem (ou não) ser executados ilimitadamente na escuta.

\section{2. palavra-partitura como esquema [errante] de execução}

Em alguns de meus processos, o desenho acontece sem palavras. Por vezes, alguns desenhos são nomeados e renomeados, ganham títulos, e noutras, permanecem sem, tinindo no vazio. Mas muitas vezes, escrever e desenhar são espécies de atos contínuos, deslizantes, inseparáveis, intertransitáveis (e o vazio continua tinindo nessas oscilações). Nem se sabe ao certo onde um começa e onde o outro termina. Nem quem é um e quem é outro. E essa situação é imprevista e irreversível. Em meus cadernos, cadernetas e blocos de anotações tudo se mistura: palavra desenhada e desenho escrito, letra avulsa, rumor-rabisco, lembretes, relatos, listas, esboços, projetos, partituras, esquemas, enfim, notas infinitas?.

Toda palavra manuscrita é desenhada? Se uma palavra for desenrolada, ela se apaga ou se acende? Silencia e/ou se transforma em outra notação, partitura de algo contínuo? Qual é a velocidade de uma anotação? E de uma notação? Qual é a velocidade de uma palavra desenhada? Qual é a velocidade de uma palavra falada? Qual é a velocidade de um desenho escutado? Qual é a velocidade de um silêncio (quase) desmaiando? $\mathrm{E}$ de um silêncio ao telefone? Qual é a velocidade de uma palavra não dita? Do rumor de uma boca de costas, antes ou depois de falar? Como a voz aprende a carregar e a desenhar palavras (Zumthor)? Como escrever-desenhar em voz alta? Desenhar-anotar seria também uma forma de escrever em alguma voz (baixa, rasteira, plana, tácita)? 


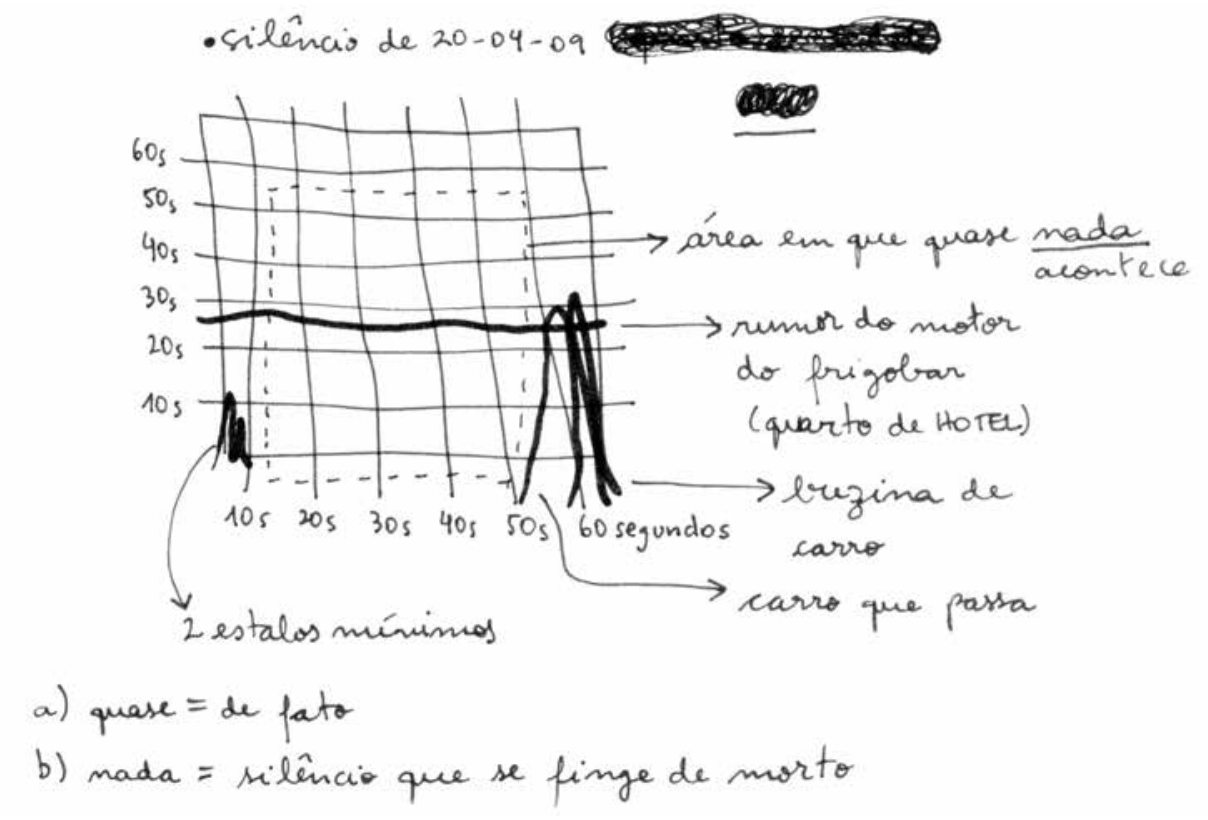

Figura 8 - Raquel Stolf, assonâncias de silêncios [coleção], 2007-2010. Detalhe de nota-desenho de escuta da publicação.

Uma palavra manuscrita começa sobre uma linha em branco (pautada ou imaginada), no atritorumor da ponta do lápis ou caneta sobre alguma superfície e desenha um contorno de sentido. Ou desenha um pressentimento de sentido. Uma palavra pode se tornar a própria linha em branco, frágil e inapreensível, ao ser desenrolada? E ao ser enrolada, escrita, desenhada, o que se escuta?

Cage $(1996$, p.96) escreve que começou a ouvir com seus ouvidos, e depois passou a escutar com os olhos. $\mathrm{O}$ uso de palavras em minhas publicações sonoras envolve um processo de escrita em que a palavra pende, oscila, desvia e pode se tornar uma espécie de palavra-partitura, catalisando desdobramentos sonoros e experiências acústicas. Gosto também de pensar a proposição de uma escuta porosa, estremecida e que pode vir a absorver ruídos do entorno, percebendo e reinventando variações entre barulho, ruído e rumor. Uma escuta porosa pode acontecer como travessia e como um canal.

Entre um silêncio sonoro (rumor incessante sob tudo) e um silêncio que transita semanticamente na própria escuta (silêncio acústico), as notasdesenhos de escuta podem ser pensadas como combinações entre esquemas-diagramas com palavras-partituras. Algo pode se desdobrar para fora ou nas bordas das notas-desenhos, em seu encontro com um leitor-ouvinte.
Tentando anotar-desenhar o que se ouve-escuta pode-se empilhar camadas simultâneas de uma paisagem sonora cotidiana (Schafer), esboçando relevos silenciosos, num registro que passa a ser também uma partitura provisória. Tentando escutar o que se desenha-escreve, oscila-se entre sentidos.

Se o uso heterogêneo do som pelos artistas (e também em minhas proposições de silêncio e vazio) suscitam reflexões em torno de diferentes experiências entre audição e escuta, propondo-se posições específicas ou modos de escuta (como escutas flutuantes, ativas, porosas, entre outras modulações acústicas), essas reflexões relacionamse sobretudo com proposições de sentido. Escutar implica em um estar à escuta, como sublinha JeanLuc Nancy (2014), em que estar em situação de escuta "é sempre estar à beira do sentido, ou num sentido de borda e extremidade, como se o som não fosse precisamente nada de outro que não este bordo, esta franja ou esta margem" (2014, p.19). Portanto, seria possível manter a escuta oscilando nessa borda invisível, próxima a uma iminência de sentido, num estado movediço?

Aderências provisórias: se "escutar é aguçar o ouvido" (NANCY, 2014, p.16), entre desenhar um som e anotar um ruído, o que pisca-aguça é o mundo como um processo ${ }^{8}$. E, construir notasdesenhos que tentam absorver algum rumor do 
entorno talvez envolva a proposição de escuta desse processo incessante - de uma escuta do mundo.

\section{NOTAS}

1. O presente texto integra as pesquisas que venho desenvolvendo na Universidade do Estado de Santa Catarina - UDESC desde 2011, intituladas Investigações sob publicações sonoras [entre disco, palavra-partitura e notas- desenhos de escuta] (2011-2014) e Processos de escrita / Escuta de processos [articulações entre voz, palavra e silêncio em publicações sonoras] (2015-2017). Consiste numa segunda versão, revista e ampliada, do texto Sob notas-desenhos de escuta e palavras-partituras, que participou da publicação organizada por Diego Rayck, intitulada Aqui desenho: Desenho espaço: correspondências e desvios. Florianópolis: Corpo Editorial, 2012.

2. Esse projeto compõe um dos blocos de minha pesquisa de doutorado, na qual investiguei uma indissociação entre usos do som na arte contemporânea e a proposição de situações e modos de escuta, relacionadas também com processos de escrita, sendo que o presente texto desdobra algumas de suas reflexões.Ver-escutar: STOLF, Maria Raquel da Silva. Entre a palavra pênsil e a escuta porosa [investigações sob proposições sonoras]. Tese (Doutorado em Artes Visuais). Instituto de Artes, Universidade Federal do Rio Grande do Sul, Porto Alegre, 2011. (com CD de áudio). Disponível em: www.raquelstolf. com/wp-content/uploads/2000/09/TESE_ RaquelStolf_20111.pdf. Acesso em 14/05/2017.

3. Mar paradoxo consiste num desdobramento do projeto assonâncias de silêncios, que envolve o processo de gravar, propor, escrever-desenhar, escutar e colecionar silêncios, desenvolvido desde 2007. A parte sonora do projeto pode ser escutada em: soundcloud.com/marparadoxo/tracks. Acesso em 11/05/2017.

4. Uma referência crucial para o projeto foi a leitura recorrente do livro Especies de espacios de Georges Perec, e os processos de escrita propostos pelo OULIPO.

5. Cage escreve que "não existe silêncio" (2007, p. 191), pois há sempre algo que produz som/ruído, ao mesmo tempo em que "O silêncio é simplesmente... uma questão mental. Uma questão de saber se uma pessoa está escutando os sons que não está provocando. Não sou eu que faço os pássaros cantarem, mas eu os ouço e não estou falando: a isso chamamos de silêncio. 0 silêncio é um meio de ouvirmos o que nos cerca" (Cage, 1978, s/p). Em sua experiência na câmara anecoica, narrada em De segunda a um ano (1985), ele sublinha as mesmas reflexões acima, indicando a escuta do ruído incessante de seu corpo (o som grave do sangue em circulação e o agudo do sistema nervoso).

6. Disponível para audição-escuta em: https:// soundcloud.com/raquelstolf/49silenciosempilhados. Acesso em 12/05/2017.

7. Vide o projeto e livro Cadernos de desenho (org. Aline Dias. Corpo Editorial: Florianópolis, 2011), do qual participei e que assinala essas relações deslizantes e que se retroalimentam.

8. Para Cage, O mundo, o real, não é um objeto. É um processo. In: CAGE, John; CHARLES, Daniel. Para los pájaros. Cidade do México: Alias, 2010, p.92, trad. nossa.

\section{REFERÊNCIAS}

BLANCHOT, Maurice. O Espaço Literário. Rio de Janeiro: Rocco, 1987.

CAGE, John. De segunda a um ano. São Paulo: Hucitec, 1985.

_-_. Silencio. Madrid: Árdora Ediciones, 2007.

_.. JOHN CAGE: DOIS TOQUES PARA O BRASIL (Entrevista). In: Código 3. Salvador, agosto 1978.

_-. (Entrevista). LOPES, Rodrigo Garcia. Vozes

e Visões: Panorama da Arte e Cultura NorteAmericanas Hoje. São Paulo: lluminuras, 1996.

CAGE, John; CHARLES, Daniel. Para los pájaros. Cidade do México: Alias, 2010.

DIAS, Aline (org.). Cadernos de desenho. Corpo Editorial: Florianópolis, 2011.

NANCY, Jean Luc. À escuta. Belo Horizonte, Ed. Chão da Feira, 2014.

PEREC, Georges. Especies de espacios. Barcelona: Montesinos, 2007. 
SCOVINO, Felipe (org.). Encontros - Cildo Meireles.

Rio de Janeiro: Beco do Azougue, 2009.

SCHAFER, R. Murray. O ouvido pensante. São Paulo: Ed. Unesp, 1991.

STOLF, Maria Raquel da Silva. Entre a palavra pênsil e a escuta porosa [investigações sob proposições sonoras]. Tese (Doutorado em Artes Visuais). Instituto de Artes, Universidade Federal do Rio Grande do Sul, Porto Alegre, 2011. (com CD de áudio). Disponível em: http://www.raquelstolf. com/wp-content/uploads/2000/09/TESE_ RaquelStolf_20111.pdf.

ZUMTHOR, Paul. Escritura e nomadismo: entrevistas e ensaios. Cotia: Ateliê Editorial, 2005.

\section{SOBRE A AUTORA}

Raquel Stolf é artista, pesquisadora e professora nos cursos de Graduação e Pós-Graduação em Artes Visuais da Universidade do Estado de Santa Catarina - UDESC. Mestre e doutora em Artes Visuais (Poéticas Visuais) pela Universidade Federal do Rio Grande do Sul - UFRGS. 


\section{INSTRUÇÕES AOS AUTORES DE TEXTOS}

\section{INSTRUCTIONS FOR THE AUTHORS}

a) A Revista Arteriais aceitará textos em língua portuguesa, inglesa e espanhola. Todos os trabalhos deverão ser enviados por e-mail (revista.arteriais@ gmail.com) à: Editora da Revista Arteriais.

b) A Revista Arteriais não aceitará a submissão de mais de um artigo do mesmo autor e ou coautor para um mesmo número ou em números sucessivos da revista.

c) $\mathrm{O}(\mathrm{s})$ autor(es) que tiver(em) seu texto aprovado deverá(ão) enviar à Editoria da Revista uma Carta de Cessão (modelo Revista Arteriais), cedendo os direitos autorais para publicação, em formato eletrônico, em regime de exclusividade e originalidade do texto, pelo período de 2 (dois) anos, contados a partir da data de publicação do artigo na Revista.

d) Os Artigos deverão ter uma extensão entre $12 \mathrm{e}$ 24 páginas, incluindo resumo, abstract, palavraschave, texto e referências.

e) As Resenhas deverão apresentar entre quatro e seis páginas e as Entrevistas, de dez a quinze páginas.

f) Todos os trabalhos deverão ser enviados anexados ao e-mail revista.arteriais@gmail.com, em arquivo no programa Word for Windows 7.0;

g) Os textos dos Artigos, Resenhas e Entrevistas devem ser escritos em Times New Roman, fonte 12, espaço 1.5, margens 2,5;

h) A primeira página do texto dos Artigos deve conter:

TÍTULO

Resumo com cerca de 08 (oito) linhas, alinhamento à esquerda, contendo campo de estudo, objetivo, método, resultados e conclusões. O Resumo deve ser colocado logo abaixo do título e acima do texto principal.

Três (3) palavras-chaves, alinhamento justificado.

i) Em separado, deverá ser enviada uma página com o título dos Artigos, Resenhas e Entrevistas, a) ARTERIAIS Journal accepts papers in Portuguese, English and Spanish. All the papers might me sent by e-mail (revista.arteriais@gmail. com) to: Arteriais Journal Editor;

b) Arteriais Journal will not accept the submission of more than one paper from the same author and/ or co-author for the same issue or for a successive issue of the journal;

c) The author(s) with an approved paper must send to the Editor of the magazine a Grant Letter (Arteriais Journal model), assigning the publication rights, in electronic format, due to the regime of exclusivity and originality of the text for the term of 2 (two) years, which might be counted after the publication of the paper in the magazine;

d) The articles might have an extension of 12 to 24 pages, including abstract, English and Portuguese, keywords, text and references;

e) The reviews must have four to six pages and interviews must have ten to fifteen pages;

f) All the papers must be sent attached to the e-mail revista.arteriais@gmail.com, in Word for Windows 7.0 format;

g) All the Articles, Reviews and Interviews must be written in Times New Roman, font 12, space 1.5, margins 2.5;

h) The first page of the Articles must contain:

TITLE

Abstract with an average of 08 (eight) lines, aligned to the left, containing field of study, objectives, methodology, results and conclusion. The Abstract must come right after the title and before the main text.

Three (03) keywords, justified alignment

i) A separate sheet must be sent containing the title of the Article, Review and Interview, followed by the identification of the author(s) - full name, institution, function, address mail, phone and e-mail; 
seguido da identificação do(s) autor(es) - nome completo, instituição à qual está(ão) ligado(s), cargo, endereço para correspondência, fone e e-mail.

j) Incluir um Curriculum Vitae resumido com extensão máxima de 150 palavras, contendo as principais atividades na área do(s) autor(es) dos Artigos, Resenhas e Entrevistas.

k) Os textos devem ser escritos de forma clara e fluente.

l) As notas dos Artigos devem vir ao final do texto, em espaço simples, fonte tamanho 12 e alinhamento justificado.

m) Nos Artigos as citações com menos de três linhas devem ser inseridas no texto e colocadas entre aspas, seguidas da indicação da fonte pelo sistema autor-data. As citações que excederem três linhas devem ser colocadas em destaque, fonte 11 , espaço simples, entrada alinhada a $4 \mathrm{~cm}$ da margem, à esquerda, seguidas da indicação da fonte pelo sistema autor-data. No caso de citações de obras em língua estrangeira, essas devem aparecer no texto conforme o original podendo ser apresentadas as respectivas traduções para o português, em nota de rodapé, caso a língua de origem não seja espanhol ou inglês.

n) As indicações das fontes entre parêntesis, seguindo o sistema autor-data, devem ser estruturadas da seguinte forma:

Uma obra com um autor: (BARROS, 2011, p.30)

Uma obra com até três autores: (MANESCHY; SAMPAIO, 2007, p.120)

Uma obra com mais de três autores: (SARRAF et al., 2010, p.21-22)

Mesmo no caso das citações indiretas (paráfrases), a fonte deverá ser indicada, informando-se também a(s) página(s) sempre que houver referência não à obra como um todo, mas sim a uma ideia específica apresentada pelo autor.

o) Tabelas e quadros devem ser anexados ao texto, com a devida numeração (ex. Tabela 1, etc.). No corpo do texto deve ser indicado o lugar das tabelas.

p) Não serão aceitos artigos que estiverem fora das normas editoriais. O meta-artigo (template) pode ser visualizado em link da revista. A critério dos editores, poderá ser estabelecido um prazo j) Include a brief Resume with no more than 150 words, containing the main activities in the area of the author(s);

k) The texts must be written on a clear and objective way;

I) The notes of the article must come at the end of the text, space simple, font 12 and justified alignment;

m) For the Articles, the quotes with less than three lines must come along with the text between quotation marks, followed by the indication of the reference by the system author-date. The quotations that exceed three lines must be emphasized, font 11, space simple, entry aligned at $4 \mathrm{~cm}$ of the margin, to the left, followed by the indication of the reference by the system author-date. In the case of quotations from works in foreign language, they must come according the original reference and may be translated to Portuguese, in the area for the footnotes, if the original language is not Spanish or English;

n) The indications of the references between parentheses, following the system author-date, must be structured according to the following way:

One reference with one author: (BARROS, 2011, p.30)

One reference with until three authors: (MANESCHY; SAMPAIO, 2007, p.120)

One reference with more than three authors: (SARRAF et al., 2010, p.21-22)

Even in the case of indirect quotations (paraphrase), the reference must be pointed out, also informing the page(s), even if there is a reference not to the general work, but to a specific idea presented by the author;

o) Tables and charts must be attached to the text, with the proper numeration (ex. Table 1 etc.). The place of the Tables must be indicated in the text;

p) Articles that do not follow the Editorial rules will not be accepted. The meta-Article (template) might be visualized through a link on the homepage of the magazine. At the discretion of the editors, a certain period can be set so that the author(s) can make a revision of the text (corrections of references, quotations, grammar, and spelling). In this case, the failure to follow the deadline and 
determinado para que o(s) autor(es) efetue(m) uma revisão do texto (correções de referências, citações, gramática e escrita). Nesse caso, o não cumprimento do prazo e/ou a inadequação da revisão poderão implicar a não aceitação do trabalho para publicação.

\section{REFERÊNCIAS:}

Devem ser apresentadas em espaço simples, com alinhamento apenas à esquerda, seguindo as normas da ABNT abaixo exemplificadas.

\section{LIVROS}

SOBRENOME, Inicial do prenome(s) do(s) Autor(es). Título do trabalho: subtítulo [se houver]. edição [se não for a primeira]. Local de publicação: Editora, ano.

\section{PARTES DE LIVROS (CAPÍTULOS, ARTIGOS EM COLETÂNEAS, ETC.)}

SOBRENOME, Inicial do prenome(s) do(s) Autor(es) da Parte da Obra. Título da parte. In: SOBRENOME, Inicial do prenome(s) do(s) Autor(es) da Obra. Título do trabalho: subtítulo [se houver]. edição [se não for a primeira]. Local de publicação: Editora, ano. página inicial-final da parte.

\section{ARTIGOS EM PERIÓDICOS}

SOBRENOME, Inicial do prenome(s) do(s) Autor(es) do Artigo. Título do artigo. Título do Periódico, Local de publicação, número do volume, número do fascículo, página inicial-final do artigo, data

\section{TRABALHOS EM ANAIS DE EVENTOS CIENTÍFICOS}

SOBRENOME, Inicial do prenome(s) do(s) Autor(es) do Trabalho. Título do trabalho. In: NOME DO EVENTO, número do evento, ano de realização, local. Título. Local de publicação: Editora, ano de publicação. página inicial-final do trabalho.

\section{IMAGENS}

As imagens devem ser apresentadas numeradas, em arquivo (aproximado) de $21 \times 26 \mathrm{~cm}$ e 300 dpi, enviadas no formato JPG. As miniaturas das imagens com: autor, título, técnica, dimensões, fonte e autoria, devem vir no corpo do texto.
I or inadequacy of the review may lead to the rejection of the paper for publication.

\section{REFERENCES:}

They must be typed simple-spaced, aligned just to the left, following the rules from ABNT, as it follows:

\section{BOOKS}

AUTHOR'S LAST NAME, followed by the author's first name initial. Title of the work: subtitle [just if it has]. Edition [if it is not the first]. Place of publication: Publisher, year. Initial page - last page.

CHAPTER IN BOOKS (CHAPTERS, ARTICLES IN SELECTIONS ETC.)

AUTHOR'S LAST NAME, followed by the author's first name initial. In: AUTHOR'S LAST NAME, followed by the author's first name initial from the work. Title of the work: subtitle [just if it has]. Edition [if it is not the first]. Place of publication: Publisher, year. Initial page - last page.

\section{ARTICLES IN JOURNALS}

AUTHOR'S LAST NAME, followed by the author's first name initial. Title of the Journal, Place of publication, number of the volume, number of the issue, Initial page - last page.

\section{ARTICLES FROM SCIENTIFIC EVENTS ANNALS}

AUTHOR'S LAST NAME, followed by the author's first name initial. Title of the article. In: NAME OF THE EVENT, number of the event, year of realization, place. Title. Place of publication: Publisher, year of publication. , Initial page - last page.

\section{IMAGES}

Images must be submitted numbered, in a file (approx.) of $21 \times 26 \mathrm{~cm}$ and $300 \mathrm{dpi}$, sent in JPG format. Thumbnails of images also containing the following information for each one of them: author, title, technique, dimensions, source and authorship must be inside the text. 


\title{
INSTRUÇÕES AOS AUTORES DE PARTITURAS
}

\author{
INSTRUCTIONS FOR THE AUTHORS OF SCORES
}

A composição deve ser enviada em arquivo PDF com tamanho máximo de $5 \mathrm{MB}$. A partitura deve conter os seguintes elementos, de acordo com sua utilização: título da obra, instrumentação, autor, local e data de composição, letrista (se houver), indicações de andamento, compasso, dinâmica e articulação, e numeração dos compassos e páginas. Para composições que utilizam recursos especiais ou técnicas estendidas, recomenda-se o envio da bula. No caso de obras que utilizam suportes audiovisuais, os mesmos devem ser disponibilizados na forma de arquivos: MP3 para áudio, WMA para vídeo e JPG para figura. Estes arquivos devem ter tamanho máximo de $2 \mathrm{MB}$. Pode ser disponibilizada, também, uma gravação da composição em arquivo MP3 com tamanho máximo de $3 \mathrm{MB}$. Pede-se mini currículo e um texto crítico (uma lauda) apresentando o trabalho.
The composition must be sent in PDF format with the maximum of $5 \mathrm{MB}$. The score must contain the following elements, according to its use: title of the composition, instrumentation, author, date and place of composition, lyricist (if any), tempo markings, compass, dynamics and articulation, and numbering of bars and pages. For compositions using special features or extended techniques, it is recommended to send the leaflet. For works that use audiovisual media, they should be made available in the form of files: MP3 for audio, WMA for video and JPG for figure. These files must have a maximum size of $2 \mathrm{MB}$. It may also be provided a recording of the composition in MP3 file with maximum size 3 of $M B$. It is required a mini resume and a critical text (one page) presenting the work.

\section{INSTRUÇÕES AOS AUTORES DE PORTFOLIO}

\section{INSTRUCTIONS FOR THE AUTHORS OF PORTFOLIO}

Pede-se que sejam submetidas até 10 imagens, acompanhadas de mini currículo e de um texto crítico (uma lauda) apresentando o trabalho.

As imagens devem ser apresentadas numeradas, em arquivo (aproximado) de $21 \times 26 \mathrm{~cm}$ e $300 \mathrm{dpi}$, enviadas no formato JPG. Deve acompanhar um arquivo com documento em Word trazendo as miniaturas das imagens contendo, ainda, as seguintes informações para cada imagem: autor, título, técnica, dimensões, fonte e autoria. Caso haja dados desconhecidos, fazer uso de s.d., de acordo com a sequência de informações indicadas aqui.
It is required to be submitted up to 10 images accompanied by mini resume and a critical text (one page) presenting the work.

Images must be submitted numbered, in a file (approx.) of $21 \times 26 \mathrm{~cm}$ and $300 \mathrm{dpi}$, sent in JPG format. It is required a document in Word file with bringing the thumbnails of images also containing the following information for each one of them: author, title, technique, dimensions, source and authorship. If there is unknown data, use s.d., according to the sequence of information provided here. 


\section{CONTATO}

\section{CONTACT}

Universidade Federal do Pará

Instituto de Ciêncas da Arte

Programa de Pós-Graduação em Artes

Homepage: www.ppgartes.ufpa.br/site

Revista ARTERIAIS

Avenida Governador Magalhães Barata, n.) 611,

CEP 60060-281, Belém-Pará-Brasil

E-mail: revista.arteriais@gmail.com

Homepage: http://www.periodicos.ufpa.br/index.

$\mathrm{php} / \mathrm{ppgartes} /$ index

Telefone: +55-91-3249-2905 